\author{
UNIVERSIDADE DE SÃO PAULO \\ FACULDADE DE FILOSOFIA, LETRAS E CIÊNCIAS HUMANAS \\ DEPARTAMENTO DE GEOGRAFIA \\ PROGRAMA DE PÓS-GRADUAÇÃO EM GEOGRAFIA HUMANA
}

\title{
APLICAÇÃO DO MECANISMO DE DESENVOLVIMENTO LIMPO: O CASO NOVAGERAR
}

\section{Gleice Donini de Souza}

Dissertação apresentada ao Programa de Pós-graduação em Geografia Humana do Departamento de Geografia da Faculdade de Filosofia, Letras e Ciências Humanas da Universidade de São Paulo, como exigência para obtenção do título de mestre em geografia. 


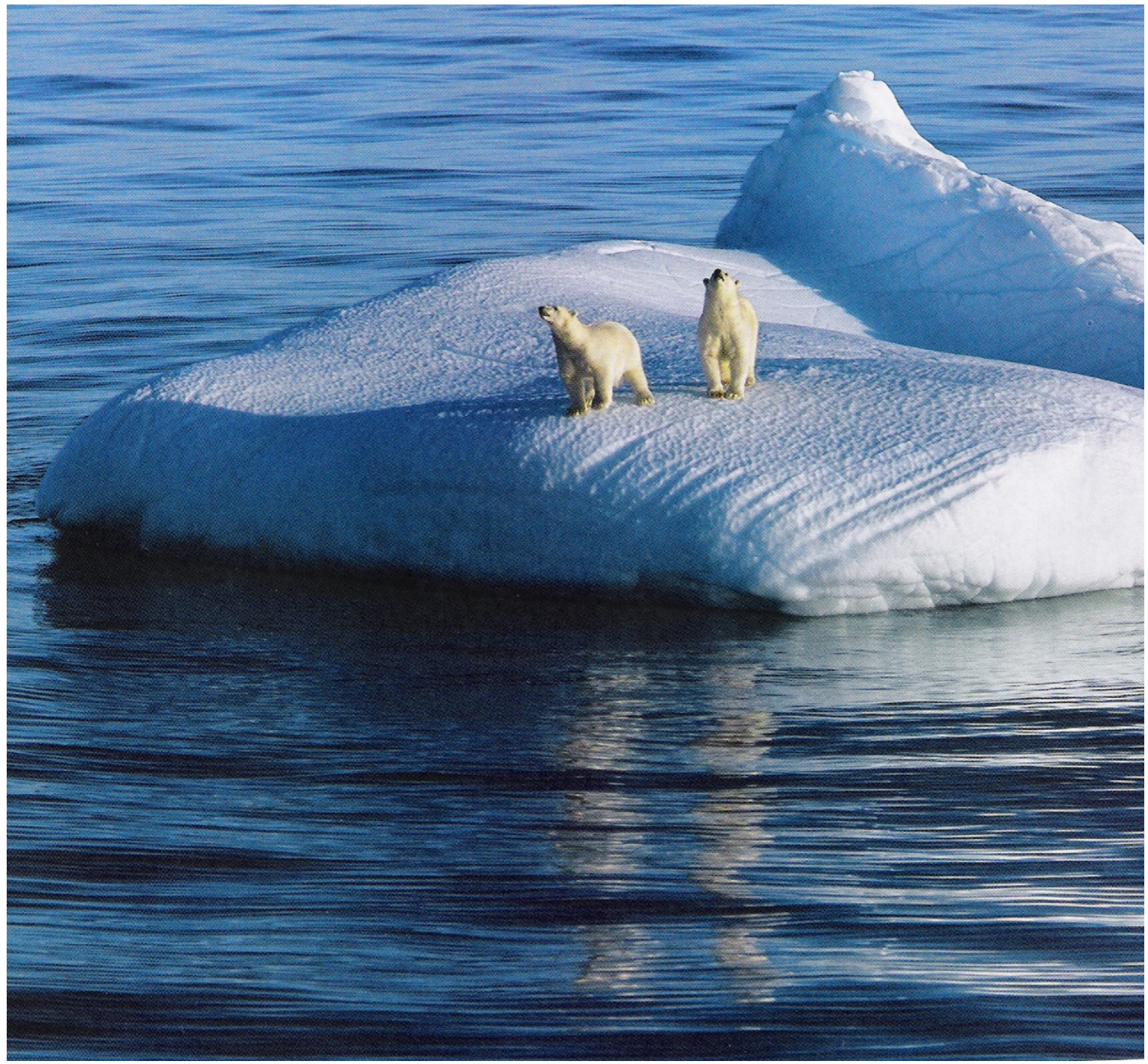

Paul Nicklen. Revista National Geographic. Junho/2007 - ano $07-\mathrm{n}^{\circ} 87$ 


\section{AGRADECIMENTOS}

$\mathrm{Na}$ conclusão de mais uma etapa da minha carreira acadêmica, gostaria de agradecer aos meus pais, Nilson e Marlene, pelo exemplo de luta, pelo apoio e carinho. Ao Rodrigo, pela compreensão, companheirismo, carinho e amor de sempre. Ao meu irmão, Glauber, pelo companheirismo, apoio, e paciência dispensada na formatação do texto.

Ao Prof. Dr. Wagner Ribeiro pela orientação. Ao Prof. Dr. Pedro Leite Dias pela gentileza de revisar um trecho do trabalho. Aos colaboradores da CTR Nova Iguaçu e NovaGerar, Adriana Filipetto, Eduardo Gaiotto, Priscila Zidan, Ricardo Borges e Roberta Rocha que contribuíram em muito com informações para a elaboração do trabalho. Ao amigo Antonio, pela elaboração dos mapas. À Dna. Luzia, pela leitura e revisão do texto.

Ao amigo Rodolfo, pelos momentos de descontração em meio às angústias do processo de obtenção do título de mestre. À Dani, pela amizade e apoio.

E, acima de tudo, a Deus, pois é Nele que encontro forças para lutar por meus objetivos. 


\section{RESUMO}

A Convenção-Quadro das Nações Unidas sobre Mudanças Climáticas, que tem como objetivo final a estabilização das concentrações de gases de efeito estufa em um nível que impeça a interferência humana perigosa no sistema climático, estabeleceu o Protocolo de Kyoto. O Protocolo é um instrumento que permite aos Países do Anexo I (aqueles historicamente responsáveis pelas emissões de GEE) os meios de atingirem suas metas de redução de emissões de Carbono.

Para que as metas sejam atingidas, o Protocolo instituiu mecanismos de flexibilização, dos quais destacamos o Mecanismo de Desenvolvimento Limpo (MDL). O MDL prevê financiamentos de Países do Anexo I em atividade que resultem em reduções/seqüestro de Carbono em países Não Anexo I.

O primeiro projeto de MDL registrado no Comitê Executivo no mundo é o brasileiro NovaGerar, objeto deste estudo.

O propósito deste trabalho é discutir o Protocolo de Kyoto, o Mecanismo de Desenvolvimento Limpo e verificar suas oportunidades a partir do projeto NovaGerar.

Palavras chave: mudanças climáticas, Protocolo de Kyoto, Mecanismo de Desenvolvimento Limpo, NovaGerar. 


\begin{abstract}
The United Nation Framework Convention on Climate Change (UNFCCC) has as final target to establish the greenhouse gases concentration on the atmosphere in one level that impedes the dangerous human interference on the climatic system. The UNFCCC established the Kyoto Protocol, one tool which allows Annex I Countries (that ones historically responsible for greenhouse gas emissions) to achieve their reduction targets.
\end{abstract}

The Protocol put in place flexibility mechanisms - to help Annex I Countries to achieve their reduction targets - among them we highlight the Clean Development Mechanism (CDM). The CDM foresees Annex I Countries financings to activities which result in reduction/sequestration of Carbon in non Annex I Countries.

The first CDM project registered in the Executive Committee was the Brazilian NovaGerar, subject of this study.

The purpose of this text is to discuss the Kyoto Protocol, the Clean Development Mechanism and verify its opportunities based on NovaGerar project.

Key words: climate change, Kyoto Protocol, Clean Development Mechanism, NovaGerar. 


\section{SUMÁRIO}

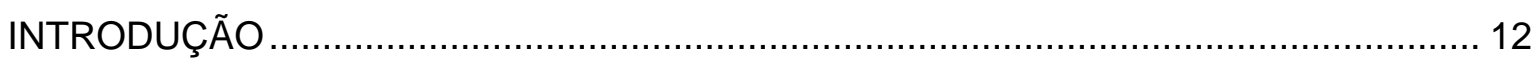

CAPÍTULO 01: MUDANÇAS CLIMÁTICAS E TEORIAS POLÍTICAS ............................. 16

1.1 a questão ambiental no cenário internacional ............................................... 17

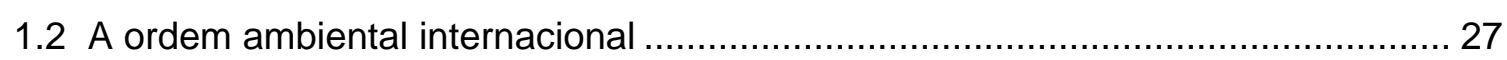

1.3 O princípio da precaução, do poluidor pagador e a segurança ambiental ............... 34 CAPÍTULO 2: MUDANÇAS GLOBAIS E A CONVENÇÃO QUADRO DAS NAÇÕES UNIDAS SOBRE MUDANÇAS CLIMÁTICAS (CQNUMC) …....................................... 44

2.1 As mudanças climáticas e os relatórios do International Panel on Climate Change

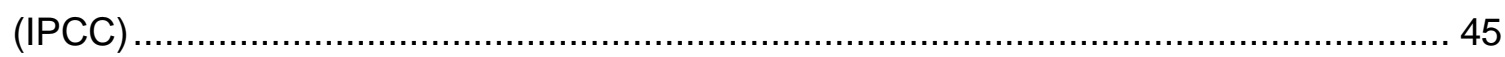

2.2 A Convenção Quadro das Nações Unidas sobre Mudanças Climáticas ................. 59

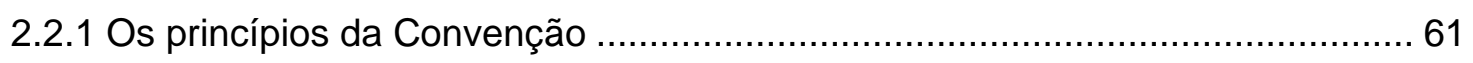

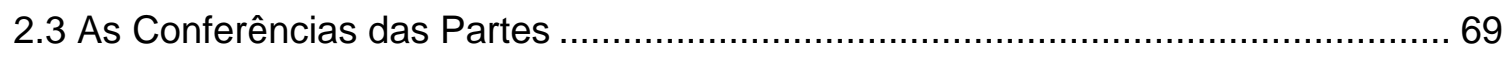

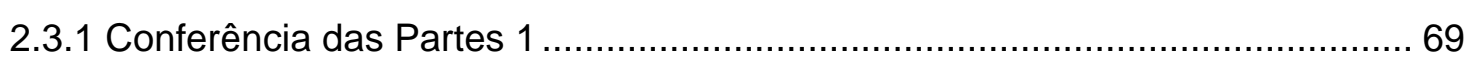

2.3.2 Conferência das Partes 2 ....................................................................... 70

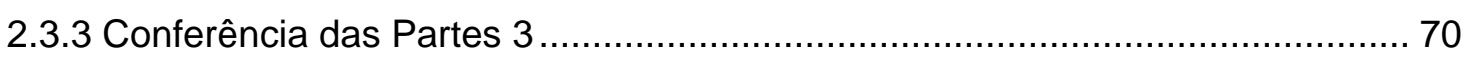

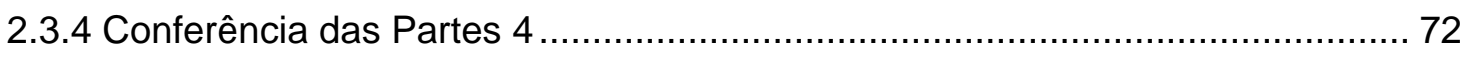

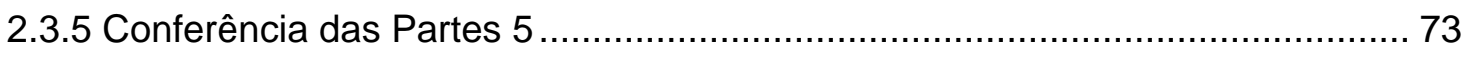

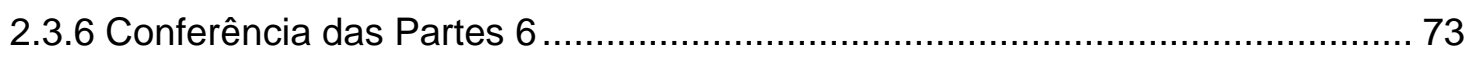

2.3.7 Conferência das Partes 6 Bis ............................................................ 74

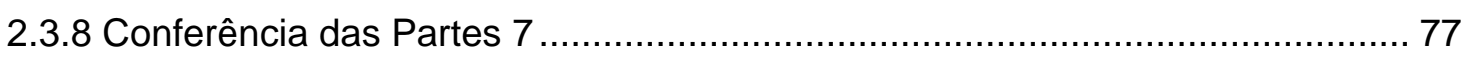

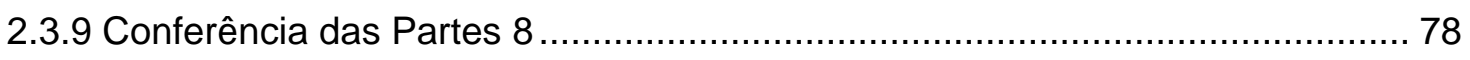

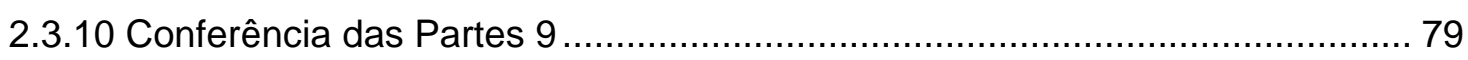

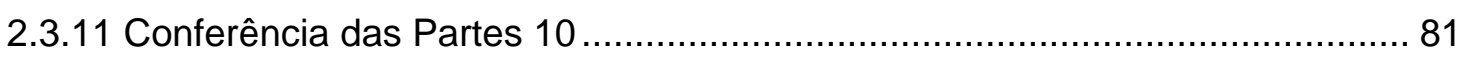

2.3.12 Conferência das Partes 11 - Reunião das Partes 1 (MOP 1) ........................ 83

2.3.13 Conferência das Partes 12 - Reunião das Partes 2 (MOP 2) ......................... 83

CAPÍTULO 3: O PROTOCOLO DE KYOTO E OS MECANISMOS DE FLEXIBILIZAÇÃO

86

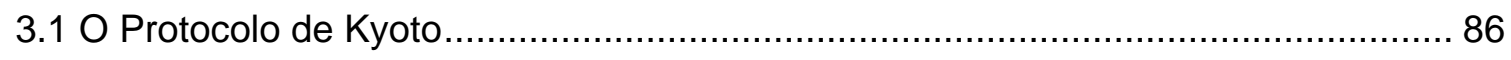

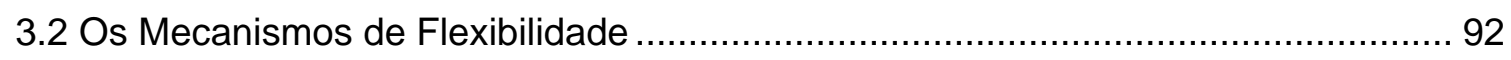

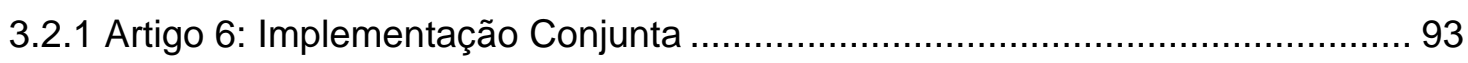

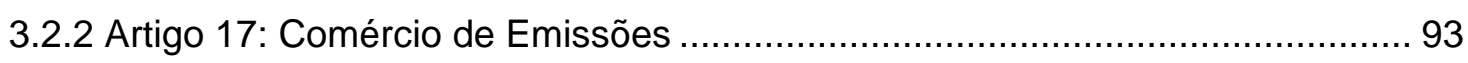

3.3.3 Artigo 12: Mecanismo de Desenvolvimento Limpo ........................................ 94

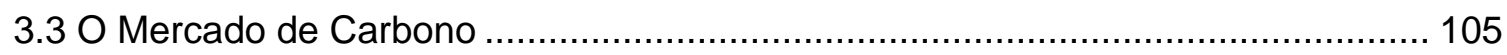


CAPÍTULO 4: O MUNICÍPIO DE NOVA IGUAÇU E A CENTRAL DE TRATAMENTO DE

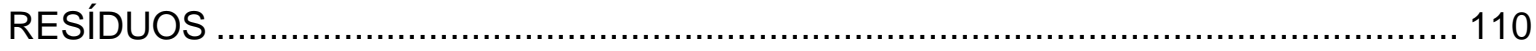

4.1 Caracterização do Município de Nova Iguaçu .................................................... 111

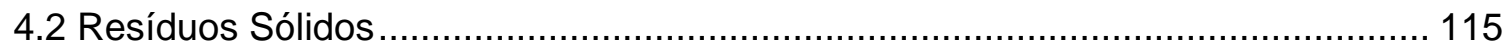

4.2.1 Resíduos Sólidos no Brasil e no Rio de Janeiro ........................................... 119

4.3 Central de Tratamento de Resíduos de Nova Iguaçu ........................................ 121

4.3.1 A Estrutura da CTR Nova Iguaçu ............................................................. 123

CAPÍTULO 5: NOVAGERAR - O PRIMEIRO PROJETO DE MDL REGISTRADO NO

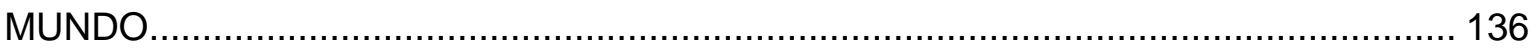

5.1 A oportunidade a partir da CTR Nova Iguaçu...................................................... 136

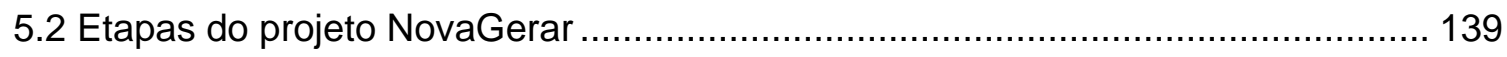

5.2.1 Documento de Concepção do Projeto (Project Design Document - PDD)...... 139

5.2.1.1 Descrição Geral das Atividades do Projeto............................................ 140

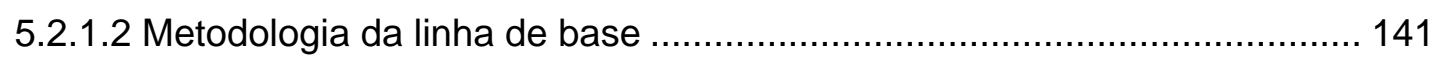

5.2.1.3 Duração da atividade do projeto ...................................................... 149

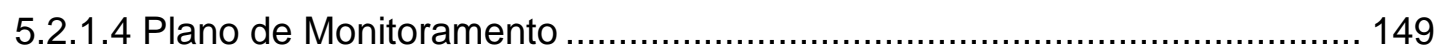

5.2.1.5 Cálculos de Emissões de GEE pelas fontes ........................................ 151

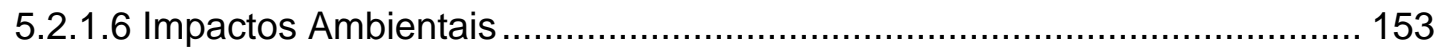

5.2.1.7 Comentários das Partes Interessadas (Stakeholders)............................ 154

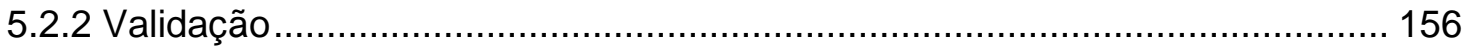

5.2.3 Aprovação pela Autoridade Nacional Designada ....................................... 158

5.2.4 Submissão ao Conselho Executivo para Registro ..................................... 159

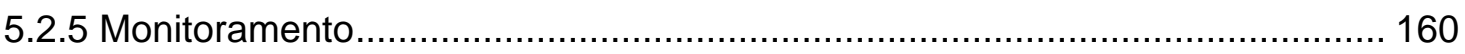

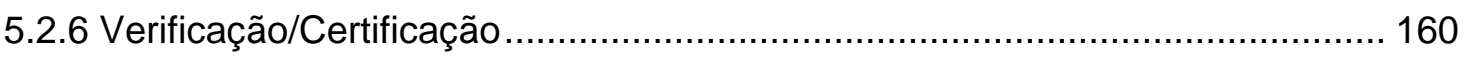

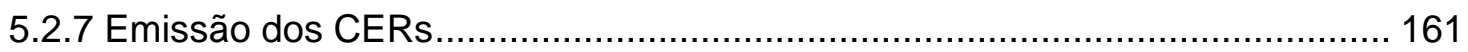

5.3 Benefícios socioambientais do projeto NovaGerar ........................................... 161

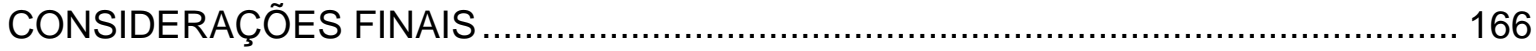

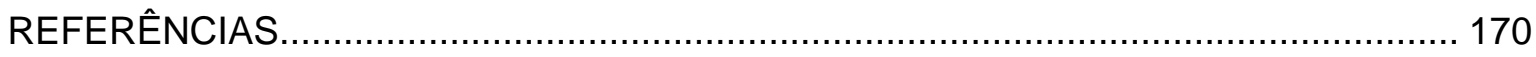




\section{LISTA DE FIGURAS}

Figura 1: Variações na temperatura da superfície da Terra ......................................... 53

Figura 2: Indicadores da influência humana na atmosfera durante a Era Industrial ......... 54

Figura 3: Central de Tratamento de Resíduos Nova Iguaçu......................................... 124

Figura 4: Manta de polietileno de alta densidade (PEAD) ....................................... 125

Figura 5: Aterro Sanitário - CTR Nova Iguaçu ........................................................ 126

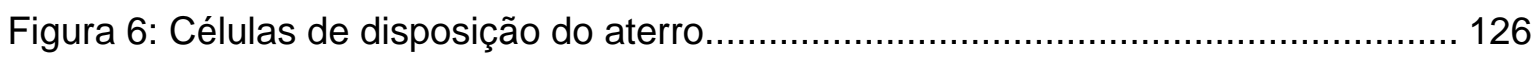

Figura 7: Corte esquemático do aterro sanitário da CTR Nova Iguaçu ........................ 127

Figura 8: Sistema de Tratamento de percolados ........................................................ 128

Figura 9: Sistema de Tratamento dos Resíduos de saúde ........................................... 129

Figura 10: Caminhão de transporte de resíduos....................................................... 131

Figura 11: Caminhão de transporte de resíduos.................................................... 131

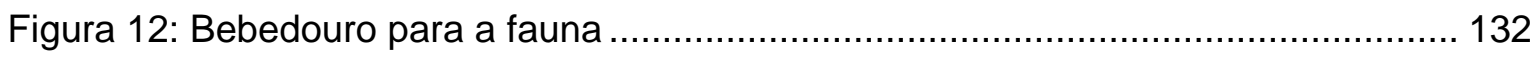

Figura 13: Centro de Educação Ambiental .................................................................. 133

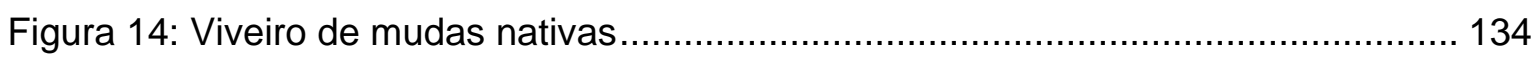

Figura 15: Quadro demonstrativo do sistema integrado de queima de biogás com geração de crédito de carbono e energia elétrica em aterro sanitário 150

\section{LISTA DE TABELAS}

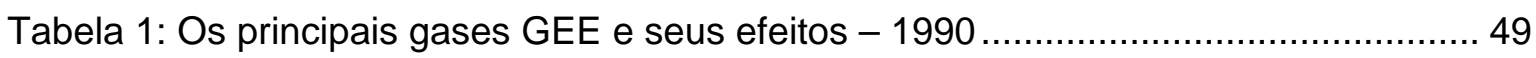

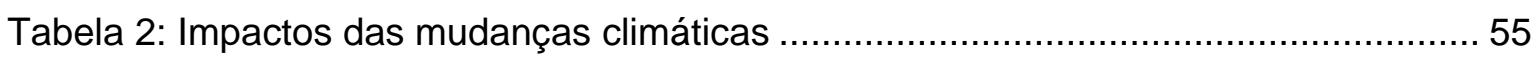

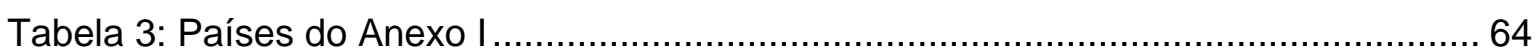

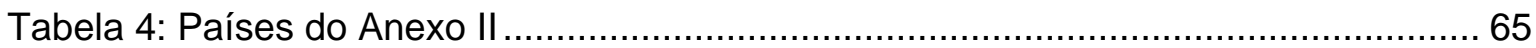

Tabela 5: Anexo B do Protocolo de Kyoto - Compromisso de redução ou limitação quantificada de emissões (porcentagem do ano base ou período) …............................ 88

Tabela 6: Total de Emissões de CO2 em 1990, usado para fins do artigo 25 do Protocolo de Kyoto (partes componentes do Anexo I)* .......................................................... 89

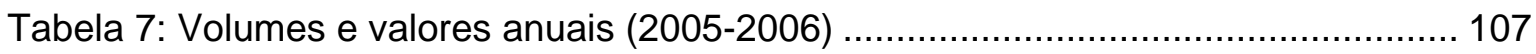

Tabela 8: Quantidade de lixo coletado, em número absoluto e relativo, por tipo de destinação final - Brasil - 1989/2000 ................................................................. 120

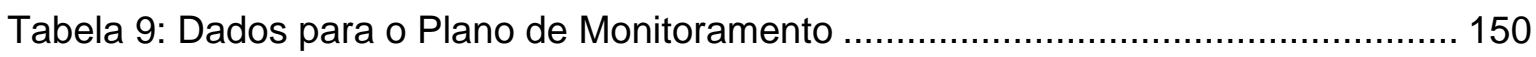

Tabela 10: Resumo da linha de base e das Emissões do Projeto (em tCO2e), depois do ajuste para conservação (redução de $20 \%$ ) 


\section{LISTA DE GRÁFICOS}

Gráfico 1: Catástrofes naturais 37

Gráfico 2: Contribuição dos GEE para o aquecimento global - 1990 49

Gráfico 3: Contribuições das fontes de degradação ambiental para o efeito estufa - 1990

Gráfico 4: Número de atividades de projeto do MDL 102

Gráfico 5: Total de Atividades de Projeto do MDL no Mundo (total: 1964 projetos)..... 103

Gráfico 6: Reduções de Emissões de CO2e para o primeiro período de obtenção de crédito 104

Gráfico 7: Reduções de Emissões para o Primeiro Período de Obtenção de Crédito (3.116 milhões de t CO2eq) 104

Gráfico 8: Número de projetos brasileiros por escopo setorial 105

Gráfico 9: Compradores MDL \& J। 108

\section{LISTA DE MAPAS}

Localização da CTR Nova Iguaçu. 


\section{ABREVIATURAS}

ABES - Associação Brasileira de Engenharia Sanitária e Ambiental ABNT - Associação Brasileira de Normas Técnicas

AOD - Autoridade Operacional Designada

CTR Nova Iguaçu - Central de Tratamento de Resíduos de Nova Iguaçu

CER - Certificado de Emissão Reduzida

CNUMAD - Conferência das Nações Unidas para o Meio Ambiente e o Desenvolvimento

COP - Conferência das Partes

CQNUMC - Convenção-Quadro das Nações Unidas Sobre a Mudança do Clima DNV - Det Norske Veritas

PDD - Project Design Document: documento de concepção de projeto de MDL ERPA - Emissions Reductions Purchase Agreement (Acordo de Compra de Emissões Reduzidas)

EMLURB - Empresa de Limpeza Urbana de Nova Iguaçu

EOD - Entidade Operacional Designada

EPA - Environmental Protection Agency

ET - Emissions Trade (Comércio de Emissões)

FAE - Fator de Ajuste de Eficácia

FEEMA - Fundação Estadual de Engenharia do Meio Ambiente

GEE - Gases de Efeito Estufa

GWP - Global Warming Potential (Potencial de Aquecimento Global)

IBAMA - Instituto Brasileiro do Meio Ambiente e dos Recursos Naturais Renováveis

IBGE - Instituto Brasileiro de Geografia e Estatística

INMETRO - Instituto Nacional de Metrologia

IPCC - Intergovernmental Panel on Climate Change

JI - Joint Implementation (Implementação Conjunta)

LFG - Landfill Gas (Gás de aterro)

L.I. - Licença de Instalação

L.O. Licença de Operação 
LULUCF - Land Use, Land Use Change and Forestation (Uso da Terra, Mudança no Uso da Terra e Florestamento)

Mecanismo de Desenvolvimento Limpo (MDL)

MOP - Meeting of Parties (Reunião das Partes do Protocolo de Kyoto)

ONU - Organização das Nações Unidas

PCF - Prototype Carbon Fund

PEAD - Polietileno de Alta Densidade

PNSB - Pesquisa Nacional de Saneamento Básico

PNUMA - Programa das Nações Unidas para o Meio Ambiente

PFPE/MDL - Projetos Florestais de Pequena Escala no Mecanismo de

Desenvolvimento Limpo

RMRJ - Região Metropolitana do Rio de Janeiro

WB NCDF - World Bank Netherlands Clean Development Facility 


\section{INTRODUÇÃO}

A problemática ambiental ganhou visibilidade no cenário internacional nas últimas décadas do século XX. Os efeitos dos desequilíbrios ambientais, que anteriormente restringiam-se à escala local, passaram a afetar o sistema Terra como um todo. Este cenário possibilitou que as questões ambientais passassem a fazer parte de discussões de âmbito internacional.

A primeira grande conferência sobre meio ambiente foi convocada em 1972 pela Organização das Nações Unidas (ONU), realizada em Estocolmo, na Suécia, e tratou de dois temas principais: o controle da poluição do ar e do crescimento populacional. A decisão da Assembléia Geral da ONU em realizar a Conferência de Estocolmo decorreu da necessidade de discutir temas ambientais que poderiam gerar conflitos internacionais.

A predominância do realismo político na Conferência de Estocolmo foi evidente. A soberania dos países foi salvaguardada e venceu a tese de nãocontrole externo em relações às políticas desenvolvimentistas praticadas por cada país. A mais relevante deliberação em Estocolmo foi o estabelecimento do Programa das Nações Unidas para o Meio Ambiente (PNUMA).

Com a criação do PNUMA, houve um incremento na ordem ambiental internacional com o desenvolvimento da abordagem de temas ambientais, culminando vinte anos mais tarde na Conferência das Nações Unidas para o Meio Ambiente e o Desenvolvimento (CNUMAD), realizada no Rio de Janeiro em 1992. A CNUMAD buscava a conciliação entre conservação ambiental e o desenvolvimento, a partir do conceito de desenvolvimento sustentável, que fora definido em 1987 no Relatório Nosso Futuro Comum como:

“(...) aquele que atende às necessidades dos presentes, sem comprometer a possibilidade de as gerações futuras de atenderem suas próprias necessidades" ${ }^{1}$

${ }^{1}$ COMISSÃO MUNDIAL PARA O MEIO AMBIENTE E DESENVOLVIMENTO. Nosso Futuro Comum. Rio de Janeiro, FGV, 1991. p.. 46 
As mudanças climáticas têm sido objeto de estudos e de implementação de políticas internacionais, dadas as conseqüências desastrosas à manutenção da vida que poderão ocorrer se não houver aplicação de mecanismos que estabeleçam parâmetros ambientais seguros.

Estudos têm mostrado que o aumento da temperatura global pode ser conseqüência do aumento da concentração de determinados gases liberados na atmosfera provenientes das ações humanas, os chamados gases de efeito estufa, dos quais destaca-se o dióxido de carbono. Esses dados geraram preocupações de âmbito mundial, que resultaram no estabelecimento da Convenção Quadro das Nações Unidas sobre as Mudanças Climáticas, que posteriormente implementou o Protocolo de Kyoto, um mecanismo de controle das emissões dos gases de efeito estufa.

O Protocolo de Kyoto estabeleceu alguns mecanismos de flexibilização para que os países do Anexo I - aqueles que historicamente apresentam os maiores índices de emissões de gases de efeito estufa - cumpram suas metas de redução de emissões. Um destes mecanismos é o Mecanismo de Desenvolvimento Limpo (MDL), que permite que países desenvolvidos financiem projetos de redução/seqüestro de carbono em países em desenvolvimento, possibilitando a captação de recursos para a promoção do desenvolvimento sustentável.

Os financiamentos propostos pelo MDL prevêem cooperação em diversos segmentos, dentre os quais destacamos: reforma dos setores de energia e transportes, promoção do uso de fontes energéticas renováveis/limpas, redução das emissões de metano no gerenciamento de resíduos, proteção de florestas e outros sumidouros de carbono. O financiamento de projetos nestes segmentos resultaria em melhorias socioambientais aos países que não necessitam reduzir as emissões de Carbono e gerariam créditos de carbono, os chamados Certificados de Emissões Reduzidas aos países do Anexo I, que seriam utilizados/contabilizados para atingir as metas de redução exigidas.

O MDL surge então como uma alternativa a ser considerada para desenvolvimento de projetos sustentáveis, pois relaciona a vertente ambiental, econômica e a social, possibilitando a geração de benefícios às partes interessadas envolvidas. 
Diante deste panorama, inúmeros projetos têm sido implementados por países - que não precisam reduzir emissões - para captação de recursos financeiros e obtenção dos créditos de carbono, fato que motivou nossa investigação. Nossa pesquisa visa a analisar a implementação do Protocolo de Kyoto por meio do primeiro projeto de MDL registrado no Comitê Executivo da Convenção, o NovaGerar.

O NovaGerar é desenvolvido no município de Nova Iguaçu no Rio de Janeiro e promove o aproveitamento do metano, que deixa de ser emitido para a atmosfera, na Central de Tratamento de Resíduos de Nova Iguaçu.

Para concretizarmos nosso trabalho utilizamos diversas fontes de informação. O levantamento bibliográfico incluiu análise de livros, artigos científicos, dissertações e teses que vêm sendo publicadas tratando da ordem ambiental internacional, desenvolvimento sustentável, mudanças climáticas, da Convenção Quadro das Nações Unidas sobre Mudanças Climáticas, dos mecanismos de flexibilização do Protocolo de Kyoto. A rede mundial de computadores também foi utilizada como meio de acesso às informações. Realizamos o trabalho de campo, em julho de 2005, no Aterro Sanitário de Adrianópolis - município de Nova Iguaçu no Rio de Janeiro, tendo em vista conhecer o funcionamento e a estrutura do projeto NovaGerar. Nosso trabalho de campo incluiu uma visita técnica à planta do aterro, além de entrevistas abertas com os responsáveis pelo NovaGerar no Rio de Janeiro.

O resultado do trabalho está dividido nos capítulos exemplificados a seguir:

No Capítulo I, Mudanças climáticas e teorias políticas, serão revistas teorias e conceitos aplicáveis à questão das mudanças climáticas em escala internacional e local, tais como realismo político, segurança ambiental, ordem ambiental internacional, desenvolvimento sustentável, o princípio das responsabilidades comuns, porém, diferenciadas, da precaução e do poluidor pagador. Para tal, foram revistos autores da Geografia Política e das Relações Internacionais, por meio da análise de livros, revistas científicas, artigos.

No Capítulo II, Mudanças Globais e a Convenção Quadro das Nações Unidas sobre Mudanças Climáticas, será apresentado um panorama geral sobre a questão das mudanças climáticas globais, discutindo os estudos realizados pelo International Panel on Climate Change (IPCC), o histórico do 
estabelecimento da Convenção Quadro das Nações Unidas sobre Mudança do Clima e as Conferências das Partes. A elaboração deste capítulo pressupôs a análise dos relatórios do IPCC, dos documentos da Convenção e das Conferências das Partes, bem como consultas a informações disponíveis na rede mundial de computadores.

No Capítulo III, O Protocolo de Kyoto e os Mecanismos de Flexibilização, discutiremos o estabelecimento do Protocolo de Kyoto e os instrumentos que possibilitam as reduções de carbono, com ênfase no Mecanismo de Desenvolvimento Limpo. O capítulo é resultado da análise do texto Protocolo de Kyoto, bem como seus desdobramentos nos documentos das Conferências das Partes, leitura de textos e artigos publicados sobre o Mecanismo de Desenvolvimento Limpo e consulta às informações disponíveis na rede mundial de computadores.

No Capítulo IV, O município de Nova Iguaçu e a Central de Tratamento de Resíduos, apresentaremos uma breve caracterização do município de Nova Iguaçu, bem como uma sucinta discussão sobre o gerenciamento dos resíduos sólidos no Brasil e no Rio de Janeiro, o histórico da constituição da Central de Tratamento de Resíduos e sua infra-estrutura. O capítulo é resultado da análise de documentos sobre resíduos sólidos, trabalho de campo à CTR Nova Iguaçu e informações disponibilizadas durante a visita, bem como consulta à rede mundial dos computadores.

No Capítulo V, NovaGerar: o primeiro projeto de MDL registrado no mundo, faremos uma análise da viabilidade da aplicação dos projetos de MDL, além da discussão de nosso objeto de estudo, o projeto NovaGerar. Para a elaboração deste capítulo tivemos como base a visita técnica à CTR Nova Iguaçu, informações disponibilizadas por meio das entrevistas, revisão dos documentos do projeto, consulta à rede mundial dos computadores.

Nas Considerações Finais, faremos uma síntese das questões apresentadas ao longo do trabalho e uma breve análise apontando reflexões acerca dos projetos de MDL que podem ser replicados possibilitando o desenvolvimento sustentável. 


\section{CAPÍTULO 01: MUDANÇAS CLIMÁTICAS E TEORIAS POLÍTICAS}

Neste capítulo, a partir da leitura de livros, artigos, teses, abordaremos brevemente as principais conferências ambientais mundiais, tendo em vista que esses eventos estruturaram o sistema ambiental internacional e permitiram a construção da ordem ambiental internacional.

Os acordos e ações resultantes das discussões acerca da questão ambiental permitiram a revisão do modelo de desenvolvimento adotado pela sociedade, culminando na estruturação do conceito de desenvolvimento sustentável. Desenvolvimento que deve estar pautado na manutenção do equilíbrio da vida no Planeta Terra, garantindo a sobrevivência das gerações futuras.

A questão das mudanças climáticas está hoje no cerne das discussões mundiais sobre a problemática ambiental, e tem sido objeto de estudos e de implementação de políticas internacionais, dadas as conseqüências desastrosas que poderão ocorrer se não houver aplicação de mecanismos que estabeleçam parâmetros ambientais seguros. Esses mecanismos, de âmbito global, estão baseados nos princípios da precaução, do poluidor-pagador e das responsabilidades comuns, porém diferenciadas, permitindo o estabelecimento da segurança ambiental.

Desta forma, neste capítulo faremos um breve histórico dos grandes marcos ambientais que trouxeram à cena mundial a questão ambiental. Em seguida apresentaremos o conceito de ordem ambiental internacional, que tem como um dos principais princípios a salvaguarda da soberania, portanto, o principal princípio do realismo político. Para finalizar, discutiremos os princípios da precaução, do poluidor-pagador, que são base para o entendimento da Convenção Quadro das Nações Unidas sobre Mudanças Climáticas, bem como o conceito de segurança ambiental. 


\section{1 a questão ambiental no cenário internacional}

A existência humana só é possível graças às condições atmosféricas e biológicas reunidas em nosso planeta - único no sistema solar com tais características. Os recursos naturais são, portanto, essenciais para a reprodução da vida.

Ao longo da história a espécie humana passou a explorar os recursos naturais de forma intensa e degradante, causando desequilíbrios na relação sociedade-natureza.

A problemática ambiental surgiu nas últimas décadas do século XX como uma crise de civilização, questionando a racionalidade econômica e tecnológica dominantes. A crise é explicada a partir de uma diversidade de perspectivas ideológicas, predominando o efeito da acumulação de capital e da maximização da taxa de lucro em curto prazo.

Os danos causados ao meio ambiente apresentam diferenças qualitativas e quantitativas em relação ao passado. Qualitativamente, observa-se que os efeitos dos desequilíbrios ecológicos não são locais como antes, hoje, eles afetam o sistema Terra como um todo. Desde a segunda metade do século $X X$, o rápido avanço tecnológico em nível planetário e o seu uso predatório, globalizaram a dimensão dos impactos ambientais. Nesse processo de modernização, tanto a tecnologia de guerra quanto a tecnologia civil potencializaram as dimensões dos desequilíbrios ecológicos.

Quantitativamente, os danos ambientais são bem maiores nos dias de hoje, pois o consumo de bens materiais e de energia aumentou consideravelmente.

A convergência dos fatores qualitativos e quantitativos no tocante à problemática ambiental, permitiu que essas questões passassem a fazer parte de discussões de âmbito internacional.

A primeira grande conferência sobre meio ambiente foi convocada em 1972 pela Organização das Nações Unidas (ONU), realizada em Estocolmo na Suécia, e foi denominada Conferência sobre Meio Ambiente Humano. A decisão da Assembléia Geral da ONU em realizar a Conferência de Estocolmo decorreu da necessidade de discutir temas ambientais que poderiam gerar conflitos 
internacionais. Esta conferência consolidou as bases da atual política ambiental adotada por todos os países, com maior ou menor rigor, nas suas legislações particulares.

Segundo RIBEIRO, a conferência foi baseada em duas teses:

"De modo geral, duas foram as teses discutidas durante o evento: de um lado, os zeristas, representados pelos países desenvolvidos, que defendiam a contenção do crescimento econômico frente à provável esgotabilidade dos recursos naturais que o ritmo de exploração da natureza poderia causar (mantidas as projeções de crescimento do PIB mundial), isto é, propunham o crescimento zero para os países dependentes, congelando-os no estágio em que se encontravam; de outro, os desenvolvimentistas, cujos adeptos eram em sua maioria países do chamado Terceiro Mundo, reivindicando o desenvolvimento, mesmo que este trouxesse consigo a poluição. Vale enfatizar que ambas as correntes reforçam o modelo de desenvolvimento instalado, pois os zeristas não previam a estagnação do crescimento das atividades econômicas nos países desenvolvidos."

$\mathrm{Na}$ conferência foram tratados dois temas principais: o controle da poluição do ar e o do crescimento populacional. Além da poluição atmosférica, discutiu-se a poluição da água e do solo provenientes da industrialização, que avançava nos países até então fora do circuito da economia internacional. $\mathrm{O}$ crescimento populacional também foi enfatizado nas discussões, pois a concepção de um crescimento baseado nos padrões norte-americanos resultaria em insuficiência de recursos naturais.

A Conferência de Estocolmo possibilitou o estabelecimento, em dezembro de 1972, do Programa das Nações Unidas para o Meio Ambiente (PNUMA), com o intuito promover ações baseadas na problemática ambiental. $O$ PNUMA encontrou uma série de dificuldades iniciais. Os países periféricos eram contra sua instauração, pois postulavam que ele seria um instrumento utilizado para barrar o desenvolvimento, colocando normas ambientais adotadas pelos

${ }^{2}$ RIBEIRO, W.C. Por dentro da Rio-92. In: SALES, W. (org.). Ecos da Rio 92: Geografia, Meio Ambiente e Desenvolvimento em Questão. Fortaleza, AGB, 1992.p.52 
países centrais. Apesar das dificuldades iniciais, o programa conseguiu, ao longo do tempo, destacar-se no cenário internacional, promovendo vários encontros, sendo o primeiro deles o Programa Regional dos Mares.

É nessa época que surge o conceito de Ecodesenvolvimento, defendido por Maurice Strong e posteriormente definido por Ignacy Sachs como sendo:

“(...) um desenvolvimento socialmente desejável, economicamente viável e ecologicamente prudente., ${ }^{\text {, }}$

Para Sachs, o ecodesenvolvimento deve fundamentar-se em cinco dimensões: sustentabilidade social, econômica, ecológica, espacial e cultural. Todas essas dimensões devem interligar-se para gerar um crescimento alternativo baseado em uma civilização do "ser" em que exista maior eqüidade na distribuição do "ter": na gestão mais eficiente dos recursos financeiros, com a consciência da limitação dos recursos naturais, na qual devem ser respeitadas as especificidades de cada ecossistema, de cada cultura e de cada local.

Em 1982, uma avaliação dos dez anos pós-Estocolmo aconteceu sob os auspícios do Programa das Nações Unidas para o Meio Ambiente (PNUMA) em Nairobi. Deste encontro emergiu um chamado para a formação de uma Comissão Mundial de Meio Ambiente e Desenvolvimento, implementada em 1983. Em 1987, os resultados dessa Comissão apareceram como o Relatório Nosso Futuro Comum, também conhecido como Relatório Brudtland, devido à presidência da Comissão da então primeira ministra da Noruega, Gro Harlem Brundtland, tendo como uma de suas principais recomendações a realização de uma conferência mundial que direcionasse os assuntos ali levantados. Nesse documento foi usada pela primeira vez a definição de desenvolvimento sustentável, como:

"O desenvolvimento sustentável é aquele que atende às necessidades do presente sem comprometer a possibilidade de as gerações futuras atenderem a suas próprias necessidades. Ele contém dois conceitos chave:

${ }^{3}$ SACHS, Ignacy. Ecodesenvolvimento: Crescer sem destruir. São Paulo: Vértice, 1986. p..113. 
- O conceito de "necessidade", sobretudo as necessidades essenciais dos pobres do mundo, que devem receber a máxima prioridade;

- A noção das limitações que o estágio da tecnologia e da organização social impõe ao meio ambiente, impedindo-o de atender às necessidades presentes e futuras." ${ }^{4}$

Ou seja, o desenvolvimento deve conciliar crescimento com conservação ambiental, garantindo acesso a todos aos recursos naturais. O discurso acerca do conceito de Desenvolvimento Sustentável deve ser minuciosamente analisado, pois é necessário entender os interesses por detrás desta concepção: assegurar possibilidades às gerações futuras de quais Estados soberanos? Quais os padrões de desenvolvimento a serem adotados? Desenvolvimento sustentável ao capitalismo - entendido como manutenção deste sistema?

Cabe aqui um parênteses, baseado nos escritos de Enrique Leff, de que a sociedade deveria portanto, sair da racionalidade econômica e construir um racionalismo ambiental. A racionalidade ambiental seria a produtividade alternativa, resultando no desenvolvimento sustentável. Segundo Sachs,

"A finitude da nave-terra e as dimensões atuais do mau desenvolvimento tornam imperiosa a aplicação desta nova racionalidade na gestão dos recursos de energia, de espaço e do meio.."

A racionalidade ambiental constrói-se mediante a articulação de quatro níveis de racionalidade:

- $\quad$ "Racionalidade substantiva: sistema de valores que orientam a construção de uma racionalidade ambiental fundada nos princípios de um desenvolvimento ecologicamente sustentável, socialmente eqüitativo, culturalmente diverso e politicamente democrático;

- Racionalidade teórica: produção conceitual orientada para a construção de uma racionalidade produtiva alternativa;

- Racionalidade técnica ou instrumental: estabelece os meios que conferem sua eficácia à gestão ambiental, incluindo as tecnologias

\footnotetext{
${ }^{4}$ COMISSÃO MUNDIAL PARA O MEIO AMBIENTE E DESENVOLVIMENTO. NosSo Futuro Comum. Rio de Janeiro, FGV, 1991. p.. 46.

${ }^{5}$ SACHS, Ignacy. Ecodesenvolvimento: Crescer sem destruir. São Paulo: Vértice, 1986. p..113.
} 
ambientais ecotécnicas, as ordenações jurídicas, os instrumentos legais e os arranjos institucionais das políticas ambientais, bem como as formas de organização do movimento ambiental para gerar as forças sociais necessárias para transformar a racionalidade econômica dominante;

- Racionalidade cultural: organiza e confere sua especificidade ao processo de mediação entre a sociedade e a natureza, entre as técnicas de produção e as normas de aproveitamento dos recursos naturais." ${ }^{\prime \prime}$

Segundo Sachs, mesmo sabendo onde queremos chegar, a questão operacional é como proceder. Por isso, deve-se dar bastante atenção à formulação de estratégias de transição de uma racionalidade econômica para a racionalidade ambiental, que deverão basear-se nas seguintes premissas:

1. "Para que tenham sentido, as estratégias de transição deverão cobrir um período de várias décadas;

2. Os países industrializados deverão assumir uma fatia mais do que proporcional dos custos de transição e do ajuste tecnológico;

3. As estratégias eficientes de transição dependerão da ousadia das mudanças institucionais, da habilidade de se projetar pacotes de políticas multidimensionais e da capacidade de se redirecionar o progresso tecnológico;

4. As estratégias de transição devem, simultaneamente, modular a demanda por meio de mudanças nos estilos de vida, nos padrões de consumo e nas funções produtivas, mediante a incorporação de técnicas ambientalmente adequadas e fazendo as escolhas locacionais corretas." $^{\prime 7}$

Portanto, a gestão ambiental do desenvolvimento sustentável está pautada no manejo integrado dos recursos naturais, tecnológicos e culturais de uma sociedade e conduz à necessidade de compreender as inter-relações que se estabelecem entre processos históricos, econômicos, ecológicos e culturais no

\footnotetext{
${ }^{6}$ LEFF, Enrique. Epistemologia Ambiental. São Paulo: Cortez, 2002. p.. 130-134

${ }^{7}$ SACHS, Ignacy. Rumo à ecossocioeconomia: teoria e prática do desenvolvimento. Paulo Freire Vieira (org.) - São Paulo: Cortez,2007. p.. 186-189.
} 
desenvolvimento das forças produtivas da sociedade. Isto nos obriga a pensar nas relações de interdependência e multicausalidade entre os processos sociais e ecológicos que condicionam o potencial produtivo dos recursos de uma formação social, seus níveis de produtividade e as condições de preservação e regeneração dos recursos naturais.

Com a criação do PNUMA, houve um incremento na ordem ambiental internacional. O crescimento na abordagem de temas ambientais culminou, vinte anos mais tarde, na Conferência das Nações Unidas para o Meio Ambiente e o Desenvolvimento (CNUMAD), realizada no Rio de Janeiro em 1992. A CNUMAD buscava a conciliação entre conservação ambiental e o crescimento, a partir do conceito de desenvolvimento sustentável.

A manutenção do modelo de desenvolvimento anteriormente adotado trouxe conseqüências desastrosas à sociedade, como contaminação do ar, da água e do solo, desertificação, extinção de espécies, aquecimento atmosférico, degelo e mudanças no nível do mar. $\mathrm{E}$, aliado a essas conseqüências ambientais, surgem a fome, a pobreza, a mortalidade e o acirramento de disputas pelos recursos necessários à sobrevivência. O desenvolvimento sustentável, portanto, surgiu como modelo alternativo ao atual.

O objetivo principal da Rio-92 foi o estabelecimento de acordos internacionais sobre acesso e conservação da biodiversidade, sobre o aquecimento global e ações que resultassem na conservação ambiental, tendo como conceitos base a Segurança Ambiental e o Desenvolvimento Sustentável. Dela participaram 178 Estados-nação, dos quais 114 chegaram a ser representados pelos respectivos Chefes de Estado.

O conceito de Segurança Ambiental, segundo RIBEIRO, estabelece que é necessário

“(...) regular o uso dos recursos naturais por meio do emprego de técnicas de manejo ambiental, de combate ao desperdício e à poluição. Se fôssemos empregar uma expressão também para este conceito, diríamos que as ações humanas dirigidas para a produção de coisas necessárias à reprodução da vida devem evitar a destruição do planeta"8

\footnotetext{
${ }^{8}$ RIBEIRO, Wagner Costa. A ordem ambiental internacional. São Paulo: Contexto, 2001. p. 114.
} 
O conceito de segurança ambiental traz a perspectiva da busca pela paz, deve-se evitar a eclosão de conflitos por recursos naturais ou pela degradação das condições de vida decorrentes de ações extraterritoriais.

Para Philippe Le Prestre,

“(...) a segurança ambiental é entendida como a proteção do meio ambiente a longo prazo (...) Mesmo que um Estado não se sinta diretamente ameaçado, pode acontecer que as profundas modificações ambientais ou que a escassez dos recursos naturais criem novas fontes de conflitos interestatais. O problema seria, por conseguinte, o de manter a ordem internacional". ${ }^{9}$

Os discussões da Rio-92 trataram das mudanças climáticas globais e do acesso e manutenção da biodiversidade, que resultaram em Convenções internacionais. Também foram elaboradas duas declarações: a do Rio (uma carta de princípios pela preservação da vida na Terra) e a Declaração de Florestas (que estabelece a intenção de manter as florestas - bastante peculiar, pois a conferência foi exatamente no Brasil tendo em vista o alerta para o desmatamento que ocorria na Amazônia). A Agenda 21 - também resultado da referida Conferência - tem como objetivo um plano de ação que visa minimizar os problemas ambientais mundiais na virada do século.

Desse evento, o resultado que nos interessa particularmente é a Convenção de Mudanças Climáticas e seus desdobramentos, que possibilitaram a instauração do Mecanismo Desenvolvimento Limpo, cujo primeiro projeto aprovado no âmbito da Convenção, o NovaGerar, é nosso objeto de estudo.

O debate sobre o fenômeno climático de aquecimento global ganhou visibilidade na cena internacional em 1987, por ocasião da publicação do relatório da ex-primeira-ministra norueguesa Gro Harlem Brundtland para a Comissão Mundial sobre o Meio Ambiente e o Desenvolvimento das Nações Unidas. No relatório Nosso futuro comum, pela primeira vez, a acumulação dos gases de efeito estufa (GEE) na atmosfera era indicada como um risco para o planeta,

\footnotetext{
${ }^{9}$ LE PRESTRE, Philippe. Ecopolítica Internacional. São Paulo, SENAC, 2000. p. 411 e 439.
} 
sendo sua mais grave conseqüência o aumento da média de temperatura da Terra.

Apesar da gravidade da denúncia, não havia então conhecimento científico capaz de verificar sua validade. Com este fim, em 1988, a ONU encomendou ao Intergovernmental Panel on Climate Change (IPCC) um estudo sobre as mudanças climáticas. A equipe de especialistas internacionais foi composta por dois mil e quinhentos pesquisadores, que publicaram um primeiro relatório em 1990.

No primeiro relatório, o grupo ofereceu como conclusão que,

“(...) uma gama de elementos sugere que existe uma influência perceptível do homem sobre o clima mundial." 10

O estudo constatou a elevação da temperatura média da Terra, oscilando em uma variação positiva entre 0,3 e $0,6{ }^{\circ} \mathrm{C}$ por década. A influência do homem no clima se daria essencialmente pela introdução na atmosfera dos chamados gases de efeito estufa (GEE). Os principais gases estufa liberados durante a queima de combustíveis fósseis e atividades humanas são o dióxido de carbono $\left(\mathrm{CO}_{2}\right)$, metano $\left(\mathrm{CH}_{4}\right)$, óxido nitroso $\left(\mathrm{N}_{2} \mathrm{O}\right)$, hidrofluorcarbonos (HFCs), perfluorcarbonos (PFCs) e hexafluoreto de enxofre $\left(\mathrm{SF}_{6}\right)$. Esses gases alteram a composição química da atmosfera, que passa a reter mais calor e aumenta a temperatura do planeta.

As conseqüências do processo de acumulação dos GEE na atmosfera, segundo a comunidade científica internacional, trará profundos impactos ambientais, sociais e econômicos, tais como: degelo das calotas polares e o conseqüente aumento do nível dos oceanos (comprometendo/impossibilitando a ocupação das regiões litorâneas); mudança no regime de chuvas; extinção de animais e plantas; desertificação; aumento dos vetores de diversas doenças.

Assim, a tese científica segundo a qual a ação do homem tem efeitos sobre o aquecimento global foi reforçada pelas conclusões dos estudos. Isso criou

${ }^{10}$ IPCC. 16 Years of Scientific Assessment in Support $f$ the Climate Convention. December 2004, p. 03. 
as condições políticas para uma ação global de controle das emissões dos GEE. Mais à frente o leitor encontrará mais detalhes deste cenário.

Entretanto, os interesses dos países que estavam presentes na CNUMAD, tais como os Estados Unidos, que não concordavam com a tese de que o homem tem efeitos sobre o aquecimento global, predominaram no texto da Convenção, que foi tênue e não trouxe a solução dos problemas advindos do aquecimento global. A decisão de maior destaque está no estabelecimento para as partes da manutenção dos níveis de emissão de 1990 dos gases de efeito estufa a partir do ano 2000 para os países desenvolvidos.

Cabe-nos questionar se esses índices são suficientes para impedir o aquecimento global. As conseqüências das mudanças climáticas serão com certeza muito mais desastrosas nos países mais pobres, pois as condições de infra-estrutura e recursos para reparar os danos são bem menores.

Após dez anos da realização da Rio 92, ocorreu a Rio + 10, Cúpula Mundial sobre Desenvolvimento Sustentável, em Johannesburgo, África do Sul. A reunião foi uma tentativa da ONU de reavaliar e implementar as conclusões e diretrizes obtidas na Rio-92, em especial, de avançar nas discussões e obter metas mais ambiciosas, específicas e bem definidas para alguns dos principais problemas ambientais de ordem global, destacando-se as mudanças climáticas, o crescimento da pobreza e seus efeitos sobre o meio ambiente, a escassez de recursos hídricos e de condições sanitárias mínimas em algumas áreas do planeta, a conservação da biodiversidade, o uso racional dos recursos naturais, inclusive das diversas fontes de energia. O objetivo da reunião, portanto, foi avaliar a implementação do conceito de desenvolvimento sustentável. Conforme afirma DINIZ,

"O propósito da conferência foi obter um plano de ação factível."11

No tocante a questão das mudanças climáticas, houve a intensificação das solicitações para que os países ratificassem o Protocolo de Kyoto, que acordado em 1997 no Japão, propõe a redução em 5,2\% da emissão de gases que provocam o efeito estufa, tendo como base as emissões de 1990. Durante a

${ }^{11}$ DINIZ, Eliezer Martins. Os resultados da Rio+10. In: Revista do Departamento de Geografia. 15 (2002) p. 33. 
Rio+10, China e Polônia anunciaram sua adesão ao acordo. O primeiro-ministro do Canadá, Jean Chretien, afirmou que pediria ao parlamento canadense que ratificasse o protocolo. Mais importante foi o anúncio do primeiro-ministro russo, Mikhail Kasyanov, do interesse de seu país em assinar o acordo. A ratificação da Rússia era fundamental porque ela representa $17,4 \%$ da emissão de GEEs. Junto com 3,3\% do Canadá e 3\% da Polônia, mais a parte dos países que já o ratificaram, teríamos 60,8\%, suficiente para a entrada em vigor do protocolo, mesmo sem apoio dos EUA.

A Rio +10 procurou cumprir o que fora proposto pela Comissão para o Desenvolvimento Sustentável, porém o que prevaleceu nas discussões foram os interesses nacionais, conforme afirma RIBEIRO:

"As divergências políticas que se manifestaram em Johannesburgo devem ser entendidas como um acirramento das posições de lideranças mundiais em defesa de interesses nacionais, algo que não é propriamente uma novidade. Na verdade, a Rio+10 permitiu um reconhecimento mais claro das intenções de diversos atores em relação à conservação ambiental. Ela permitiu vislumbrar que países como os Estados Unidos não desejam ver suas ações contidas por acordos internacionais. Mas indicou também que outros países concordam em abrir mão de parte de seus projetos para construir relações que tratem com maior eqüidade o acesso à base material que permite a reprodução da existência humana."12

As discussões são o primeiro passo para a mudança de paradigma de desenvolvimento, mas insuficientes se descoladas da prática. Deve-se se ter em mente que tipo de desenvolvimento queremos para as futuras gerações: aquele que busca somente a realização do lucro, ou o desenvolvimento/evolução do ser humano/sociedade.

${ }^{12}$ RIBEIRO, Wagner Costa. O Brasil e a Rio+10. In: Revista do Departamento de Geografia, 15 (2002) p. 39. 


\subsection{A ordem ambiental internacional}

Os seres humanos dependem de recursos naturais para sobreviverem. Não precisamos ir muito longe para provarmos essa afirmação. O papel no qual esta dissertação está impressa provém da transformação de recursos naturais: é necessário solo para o plantio das árvores, que dependem de nutrientes, água para realizarem a fotossíntese e crescerem. O corte das árvores é feito por máquinas constituídas de uma série de metais fundidos e transformados. Ao chegar à fábrica para transformação a árvore passa por processos até virar celulose e a partir daí na cadeia de produção transforma-se em papel. Durante todo esse processo são utilizados compostos químicos (sintetizados a partir de matéria-prima natural), além de água para garantirem a produção do papel. Papel que está presente de diversas formas em nossa vida. A grande questão que envolve todo esse processo é a forma de produção, o modo como esses recursos são utilizados, o manejo que é feito das árvores, a responsabilidade no uso e reutilização da água, o destino final dos resíduos do processo de produção, as emissões de gases de efeito estufa. o transporte do produto final. A diferença na degradação da natureza é o modo como é feita a exploração, de forma sustentável ou indiscriminada.

As empresas e a sociedade como um todo hoje, já estão mais conscientes da finitude dos recursos naturais. As empresas dependem de matéria-prima para manterem o ciclo da produção e dos lucros,pois sabem que o ganho final depende da maneira como exploram os recursos. Se as bases materiais são finitas, a exploração deve ser sustentável, para justamente manter as taxas de lucro.

Portanto, as ações humanas devem ser reguladas/ordenadas para que se tenha limites de intervenção, conforme coloca RIBEIRO:

"O conceito de ordem é empregado neste trabalho como medida de regulação da ação humana e como uma norma que estabelece limites para a intervenção. Por se tratar de uma ordem ambiental internacional, entende-se como aquela que é elaborada para restringir a ação humana no ambiente, seja ele natural ou não, em nível mundial. Do mesmo modo 
que se afirma uma ordem ambiental, é possível afirmar várias outras ordens internacionais."13

O modelo de desenvolvimento adotado pelos países centrais e por alguns países periféricos, resultam em problemas ambientais como poluição, desmatamentos, contaminação da água e do solo, aquecimento global, perda da biodiversidade, que não se restringem apenas a seus territórios, mas ultrapassam os limites dos Estados.

Exemplos clássicos de que as ações ultrapassam os limites dos Estados são a chuva ácida e o aquecimento global. A queima de carvão, de combustíveis fósseis e os poluentes industriais lançam dióxido de enxofre e dióxido de nitrogênio na atmosfera. Esses gases combinam-se com o hidrogênio presente na atmosfera sob a forma de vapor de água, resultando em chuvas ácidas. As águas da chuva, assim como a geada, neve e neblina ficam carregadas de ácido sulfúrico ou ácido nítrico. Ao caírem na superfície, alteram a composição química do solo e das águas, atingem as cadeias alimentares, destroem florestas e lavouras, atacam estruturas metálicas, monumentos e edificações. Um dos problemas das chuvas ácidas é o fato destas poderem ser transportadas através de grandes distâncias, podendo vir a cair em locais onde não há queima de combustíveis, portanto, extrapolando os limites da região na qual foi formada e causando sérios problemas em outras áreas. O aquecimento global é causado pela liberação de gases de efeito estufa provenientes principalmente da queima de combustíveis fósseis. A grande concentração desses gases provoca 0 aquecimento da atmosfera, o que resulta em degelo das calotas polares, mudança no regime das chuvas, que traz conseqüências desastrosas em nível global.

A percepção pela sociedade de que a problemática ambiental não se restringe aos limites dos Estados, resultou em preocupações e ações de âmbito mundial, na tentativa de regular o modo como as sociedades, representadas no Estado-nação, agem frente às questões ambientais.

Segundo RIBEIRO,

${ }^{13}$ RIBEIRO, Wagner Costa. A ordem ambiental internacional. São Paulo: Contexto, 2001. p. 16 
"(...) a ordem ambiental internacional é um conjunto de convenções internacionais que busca regular as ações humanas sobre o ambiente em escala internacional.“ ${ }^{14}$.

A ordem ambiental consolida-se quando ocorre a adesão de um país a um tratado, assegurando sua posição no cenário internacional com relação a seu assunto.

Porém um princípio prevalece como tendência na ordem ambiental internacional: a salvaguarda dos interesses nacionais das principais potências mundiais, portanto princípio fundamental do realismo político.

Como afirma RIBEIRO,

"Morgenthau foi o principal responsável pela afirmação do realismo político entre as teorias de interpretação das relações internacionais." ${ }^{15}$.

O realismo político fundamenta-se em uma concepção pluralista da natureza humana. O homem real é composto do homem econômico, político, moral, religioso. Portanto, o mundo apresenta-se imperfeito do ponto de vista racional, pois,

“(...) resulta do encontro de forças inerentes à natureza humana." ${ }^{16}$

O realismo político destaca entre seus princípios políticos o conceito de interesse definido em termos de poder, sendo este a premissa fundamental da ação dos Estados na salvaguarda da soberania. A soberania constitui-se da autoridade suprema de uma nação, que independe da autoridade de qualquer outra nação e igualmente de leis internacionais.

O realismo político traduz-se no impulso dos Estados em atingir o poder de governar. Este impulso leva os Estados a buscarem seus interesses em termos de poder no sistema internacional, e a influenciar as demais nações de

\footnotetext{
${ }^{14}$ RIBEIRO, Wagner Costa. A ordem ambiental internacional. São Paulo: Contexto, 2001. p. 93 ${ }^{15}$ RIBEIRO, Wagner Costa. A ordem ambiental internacional. São Paulo: Contexto, 2001. p.. 18

${ }^{16}$ MORGENTHAU, Hans. Politics among nations: the struggle for power and peace. New York: Alfred Knopf, 1973. p.. 04.
} 
modo a valer seus interesses particulares. A condução realista dos interesses das Nações gera uma tendência universal ao confronto, que é "freada" pelo "equilíbrio de forças", um poder "invisível" respeitado por todos os Estados.

O instinto de sobrevivência direciona os Estados a uma conduta política com limites para a violência. O instinto de sobreviver leva à prudência.

A conciliação de interesses dos Estados resulta em políticas e negociações, que são traduzidas em regulamentações - normas que ordenem os processos de exploração, imposições fiscais - princípio do poluidor pagador, subvenções - créditos fiscais, educação, modificação do direito de propriedade. No cenário internacional a conciliação resulta em Convenções e Tratados, que abrangem inúmeras questões ambientais. Esses acordos visam a "diminuir" os impactos causados pelo homem ao meio ambiente, estabelecendo como meta o "desenvolvimento sustentável".

Os Tratados e Convenções são assinados de acordo com os interesses de cada Estado, portanto, não são assinados com plena liberdade, eles traduzem, na verdade, uma relação de forças ao confirmar a vitória de uma parte e a derrota de outra. Caso um país se negue a assinar um tratado, poderá estar, com este ato violando o direito internacional ambiental. Os escritos de ARON corroboram esta afirmação:

"A expressão do Direito Internacional concretiza-se nos tratados. Mas os tratados raramente são assinados com plena liberdade por todas as partes contratantes: eles traduzem uma relação de forças, consagram a vitória de uma parte e a derrota de outra." ${ }^{17}$

Os tratados e convenções não são ferramentas atuais de ordem entre os Estados, conforme coloca ARON:

"As relações entre os Estados, como todas as outras relações sociais nunca foram puramente arbitrárias. Todas as civilizações ditas superiores distinguiram entre os membros da tribo (da cidade ou do Estado) e os estrangeiros, bem como entre diversas categorias de estrangeiros. Os tratados foram conhecidos desde a mais remota 
antiguidade, pelos egípcios e pelos hititas. Todas essas civilizações tiveram um código não-escrito que determinava o modo de tratar os embaixadores, os prisioneiros e até mesmo os guerreiros inimigos, durante o combate. Não é isto o que nos dá o direito internacional público?"18

Com relação às questões ambientais, conforme RIBEIRO, os tratados datam do início do século XX:

"Os primeiros acordos entre países tratando de temas ambientais surgiram no início do século XX. Eles nasceram da tentativa de conter a ação de colonos que chegavam às terras novas e destruíam sua base natural, em especial no continente africano. O objetivo de barrar o ímpeto destruidor dos colonizadores surgiu no interior das metrópoles para as colônias, como no Reino Unido e em terras sob seu domínio. Eles não lograram êxito." ${ }^{19}$

Em 1959, o Tratado Antártico atingiu seu objetivo: a preservação de um ambiente natural da Terra. O Tratado surgiu da iniciativa dos Estados Unidos e vigora até hoje. O argumento utilizado, que estabeleceu o destino na Antártica foi o da exploração científica do continente gelado. Porém, é necessária uma minuciosa análise dos interesses que embasaram este Tratado, pois a distribuição das bases científicas no continente não foi aleatória, indicando o interesse em marcar pontos territoriais estratégicos no continente.

A primeira grande conferência sobre meio ambiente foi convocada em 1972 pela ONU realizada em Estocolmo. A predominância do realismo político na Conferência de Estocolmo ficou evidente. A soberania dos países foi salvaguardada e venceu a tese de não-controle externo em relações às políticas desenvolvimentistas praticadas por cada país. A mais relevante deliberação em Estocolmo foi, como vimos o estabelecimento do PNUMA.

Dez anos mais tarde ocorreu no Rio de Janeiro a Conferência das Nações Unidas sobre Meio Ambiente e Desenvolvimento - Rio 92, na qual a

\footnotetext{
${ }_{17}$ ARON, R. Paz e guerra entre as nações. Brasília: Universidade de Brasília, 1986. p.. 169.

${ }_{18}$ ARON, R. Paz e guerra entre as nações. Brasília: Universidade de Brasília, 1986. p.. 168

${ }^{19}$ RIBEIRO, W. C.(org.) Patrimônio Ambiental Brasileiro. São Paulo: Editora da Universidade de São Paulo: Imprensa Oficial do Estado de São Paulo, 2003. p.. 602.
} 
cooperação prevaleceu sobre o conflito. A Conferência possibilitou a abertura para o diálogo multilateral, colocando os interesses globais como sua principal preocupação.

Os produtos da Rio-92 foram a criação da Convenção sobre Mudanças Climáticas, a Convenção sobre Diversidade Biológica, a Declaração do Rio, a Declaração sobre Florestas e a Agenda 21.

A Convenção sobre Mudanças Climáticas, tema de nosso trabalho, pode ser analisada sob a ótica das teorias e conceitos citados anteriormente.

A Convenção-Quadro das Nações Unidas Sobre a Mudança do Clima (CQNUMC), adotada na Rio-92 (Cúpula da Terra) e em vigor desde 21de março de 1994, fixou como meta estabilizar as concentrações de gases de efeito estufa num nível que a interferência humana não seja perigosa ao sistema climático.

O Protocolo de Kyoto, como produto da Convenção estabeleceu alguns princípios, dentre os quais o da precaução, o da responsabilidade comum, porém, diferenciada e o do poluidor pagador, presentes também em outros documentos da Rio-92. O princípio da precaução, que será aprofundado adiante, estabelece que mesmo na ausência de elevado grau de confiabilidade nas previsões, e levando-se em conta a magnitude dos efeitos adversos, devem ser tomadas medidas de prevenção de modo a evitar o agravamento do efeito. O princípio da responsabilidade comum, porém diferenciada e do poluidor pagador, que também será discutido adiante, estabelecem que, embora seja global o problema ambiental, caberia aos países tradicionalmente industrializados e historicamente responsáveis pelos danos ambientais, o ônus por evitar seu agravamento.

Em 1998, o Protocolo de Kyoto foi aberto para adesões. Para entrar em vigor, o Protocolo deveria ser ratificado por 55 Partes da Convenção, incluindo as Partes do Anexo I que contabilizaram 55\% das emissões de dióxido de carbono desse grupo em 1990. Porém, a entrada em vigor do Protocolo de Kyoto foi dificultada inicialmente por interesses dos países, tais como na Conferência das Partes número 6, realizada em Haia na Holanda, entre os dias 13 e 25 de novembro de 2000, na qual não foi possível estabelecer regras operacionais para o Protocolo, devido à divergência entre os Estados Unidos e os países europeus. Em função do impasse criado a conferência foi suspensa. 
Em 28 de março de 2001, a Environmental Protection Agency (EPA) anunciou oficialmente que a administração Bush não tinha mais interesse em prosseguir com as negociações internacionais para implementação do Protocolo de Kyoto. No dia 09 de abril, o vice-presidente dos Estados Unidos Richard Cheney chegou a declarar que o protocolo estava "morto". Cabe lembrar que os Estados Unidos é o principal emissor de gases estufa.

A não ratificação do protocolo pelos Estados Unidos, e os obstáculos impostos pelo mesmo dificultam as negociações. Os Estados Unidos alegavam que os estudos comprovando o aumento da temperatura da atmosfera não eram confiáveis, e que, portanto, a ratificação do Protocolo de Kyoto provocaria lapsos na economia americana, tendo em vista o modelo de desenvolvimento adotado pelo país, baseado na queima de combustíveis fósseis. Além disso, os Estados Unidos cobravam a participação de alguns países em desenvolvimento nas metas estabelecidas ao Anexo I, alegando que deveriam ser tratados como iguais. Portanto, aplica-se o conceito de realismo político às ações políticas americanas, tendo em vista a salvaguarda de sua soberania.

A retomada das discussões em Bonn (Alemanha), entre 16 e 27 de julho de 2001, foi fundamental para definir a sobrevivência e os novos rumos do Protocolo. Esta Conferência ficou conhecida como a COP 6 BIS e o seu produto mais importante foi o "Acordo de Bonn", um acordo político que garantiu a sobrevivência do Protocolo, por meio de concessões feitas para garantir a permanência de países como o Japão e a Federação Russa e ao mesmo tempo respeitando os interesses da União Européia e dos países em desenvolvimento.

A ratificação do Protocolo de Kyoto pelo governo russo possibilitou a entrada em vigor do Protocolo em 16 de fevereiro de 2005.

Os países que apresentam projetos de Mecanismo de Desenvolvimento Limpo (MDL), tais como Brasil e Índia também utilizam-se do conceito de interesse, pois de acordo com as premissas do Protocolo de Kyoto, podem receber financiamentos de países pertencentes ao Anexo I para o desenvolvimento de projetos ambientalmente sustentáveis. Além disso, o Mecanismo de Desenvolvimento Limpo possibilita a aplicação do conceito de desenvolvimento sustentável, pois permite a implantação de projetos fundamentados no tripé de desenvolvimento econômico, social e ambiental. 
Nosso objeto de estudo, o projeto NovaGerar, é resultado da aplicação do Mecanismo de Desenvolvimento Limpo em um aterro sanitário localizado no município de Nova Iguaçu no Rio de Janeiro. No projeto, o gás metano que é produzido no aterro sanitário, é drenado, canalizado e enviado para os flares, onde o metano é queimado e totalmente transformado em gás carbônico. Portanto, as emissões de metano são reduzidas atingindo as metas estabelecidas pelo Protocolo de Kyoto.

A postura dos Estados frente ao Protocolo de Kyoto apresenta o realismo político como teoria política a ser desenvolvida e aplicada, pois são salvaguardados os interesses das nações, que podem tornar-se mutáveis de acordo com o contexto político, econômico e cultural em voga. Os conceitos de segurança ambiental e prudência mantêm a vigência do Protocolo uma vez que buscam-se os interesses coletivos, a sobrevivência e o equilíbrio de forças e influências entre os Estados.

\subsection{0 princípio da precaução, do poluidor pagador e a segurança ambiental}

O quarto relatório do International Panel on Climate Change (IPCC), publicado em fevereiro de 2007, traz inúmeras evidências de que:

"O aquecimento do sistema climático não é um equívoco, é agora evidente a partir de observações sobre o aumento da temperatura do ar e dos oceanos, derretimento da neve e do gelo e aumento global do nível do mar." (tradução da autora) ${ }^{20}$

"O aumento nas médias da temperatura observado desde a metade do século XX é provavelmente devido ao aumento das emissões antrópicas de gases de efeito estufa. (...) A influência humana se estende a outros aspectos climáticos, incluindo o aquecimento dos oceanos,

\footnotetext{
${ }^{20}$ Warming of the climate system is unequivocal, as is now evident from observations of increases in global average air and ocean temperatures, widespread melting of snow and ice, and rising global average sea level. IPCC. Climate Change 2007: The Physical Science Basis. http://www.ipcc.ch/SPM2feb07.pdf -p. 05. Consultado em 05 de fevereiro de 2007.
} 
temperaturas continentais, temperaturas extremas e padrões de ventos." (tradução da autora) $^{21}$

Os estudos do IPCC concluem que o aquecimento do sistema climático é indiscutível e que a influência antrópica está trazendo conseqüências também para outras "variáveis", como os oceanos e padrões dos ventos.

"Para as próximas duas décadas é projetado um aumento de temperatura de $0,2^{\circ} \mathrm{C}$ para a série de Relatórios Especiais de Cenários de Emissões. Mesmo se as concentrações de todos os gases de efeitos estufa e aerossóis fossem mantidas constante aos níveis do ano 2000, um aumento de $0,1^{\circ} \mathrm{C}$ seria esperado." (tradução da autora) ${ }^{22}$

O aumento de temperaturas têm provocado inúmeras alterações, conforme publicado no relatório do IPCC:

"Observações desde 1961 mostram que a média da temperatura global dos oceanos tem aumentado nas profundezas de até $3000 \mathrm{~m}$ e que o oceano tem absorvido mais de $80 \%$ do calor adicionado ao sistema climático. Tal aquecimento causa a expansão da água do mar contribuindo para a elevação do mar." (tradução da autora)23

"As geleiras e a camada de neve dos hemisférios têm diminuído. O degelo das geleiras e da cobertura de gelo têm contribuído para o

\footnotetext{
${ }^{21}$ Most of the observed increase in globally averaged temperatures since the mid-20th century is very likely due to the observed increase in anthropogenic greenhouse gas concentrations. (...) Discernible human influences now extend to other aspects of climate, including ocean warming, continental-average temperatures, temperature extremes and wind patterns. IPCC. Climate Change 2007: The Physical Science Basis. http://www.ipcc.ch/SPM2feb07.pdf -p. 10. Consultado em 05 de fevereiro de 2007.

${ }^{22}$ For the next two decades a warming of about $0.2^{\circ} \mathrm{C}$ per decade is projected for a range of SRES emission scenarios. Even if the concentrations of all greenhouse gases and aerosols had been kept constant at year 2000 levels, a further warming of about $0.1^{\circ} \mathrm{C}$ per decade would be expected. IPCC. Climate Change 2007: The Physical Science Basis. http://www.ipcc.ch/SPM2feb07.pdf -p. 12. Consultado em 05 de fevereiro de 2007.

${ }^{23}$ Observations since 1961 show that the average temperature of the global ocean has increased to depths of at least $3000 \mathrm{~m}$ and that the ocean has been absorbing more than $80 \%$ of the heat added to the climate system. Such warming causes seawater to expand, contributing to sea level rise. IPCC. Climate Change 2007: The Physical Science Basis. http://www.ipcc.ch/SPM2feb07.pdf -p. 07. Consultado em 05 de fevereiro de 2007.
} 
aumento do nível do mar (cobertura de gelo não inclui contribuições da Groenlândia e do gelo Antártico)." (tradução da autora)24

"Temperaturas no topo da camada de permafrost aumentaram desde 1980 no Ártico (cerca de $3^{\circ} \mathrm{C}$ ). A área coberta por gelo diminuiu cerca de 7\% no Hemisfério Norte desde 1900, com um decréscimo de 15\% na primavera."(tradução da autora $)^{25}$

"Tendências na precipitação de várias regiões têm sido observadas de 1900 a 2005. Aumento significativo de precipitação tem sido observado na parte leste das Américas do Norte e Sul, norte da Europa e norte da Ásia central. Secas têm sido observadas no Sahel, no Mediterrâneo, no sul da África e partes do sul da África. A precipitação está variando espacialmente e temporalmente e os dados são limitados em algumas regiões. Padrões de longo prazo não têm sido observados para outras regiões avaliadas.." (tradução da autora) ${ }^{26}$

"A freqüência de chuva fortes tem aumentado em muitas áreas, consistente com o aquecimento e aumentos do vapor atmosférico." (tradução da autora) $^{27}$

\footnotetext{
${ }^{24}$ Mountain glaciers and snow cover have declined on average in both hemispheres. Widespread decreases in glaciers and ice caps have contributed to sea level rise (ice caps do not include contributions from the Greenland and Antarctic ice sheets. IPCC. Climate Change 2007: The Physical Science Basis. http://www.ipcc.ch/SPM2feb07.pdf -p. 07. Consultado em 05 de fevereiro de 2007.

${ }^{25}$ Temperatures at the top of the permafrost layer have generally increased since the 1980s in the Arctic (by up to $3^{\circ} \mathrm{C}$ ). The maximum area covered by seasonally frozen ground has decreased by about $7 \%$ in the Northern Hemisphere since 1900, with a decrease in spring of up to $15 \%$. IPCC. Climate Change 2007: The Physical Science Basis. http://www.ipcc.ch/SPM2feb07.pdf -p. 08. Consultado em 05 de fevereiro de 2007.

${ }^{26}$ Long-term trends from 1900 to 2005 have been observed in precipitation amount over many large regions. Significantly increased precipitation has been observed in eastern parts of North and South America, northern Europe and northern and central Asia. Drying has been observed in the Sahel, the Mediterranean, southern Africa and parts of southern Asia. Precipitation is highly variable spatially and temporally, and data are limited in some regions. Long-term trends have not been observed for the other large regions assessed. IPCC - Climate Change 2007: The Physical Science Basis. http://www.ipcc.ch/SPM2feb07.pdf -página 08. Consultado em 05 de fevereiro de 2007.

${ }^{27}$ The frequency of heavy precipitation events has increased over most land areas, consistent with warming and observed increases of atmospheric water vapour. IPCC - Climate Change 2007: The Physical Science Basis. http://www.ipcc.ch/SPM2feb07.pdf -página 08. Consultado em 05 de fevereiro de 2007.
} 
Todas essas alterações têm sido apontadas como "responsáveis" por desastrosos eventos climáticos, tais como furacões, secas, chuvas intensas.

O gráfico abaixo apresenta o número de catástrofes naturais de 1950 a 2004, que cresceu ao longo do século XX, chegando ao ápice na década de 90, coincidentemente a década mais quente do século.

\section{Gráfico 1: Catástrofes naturais}

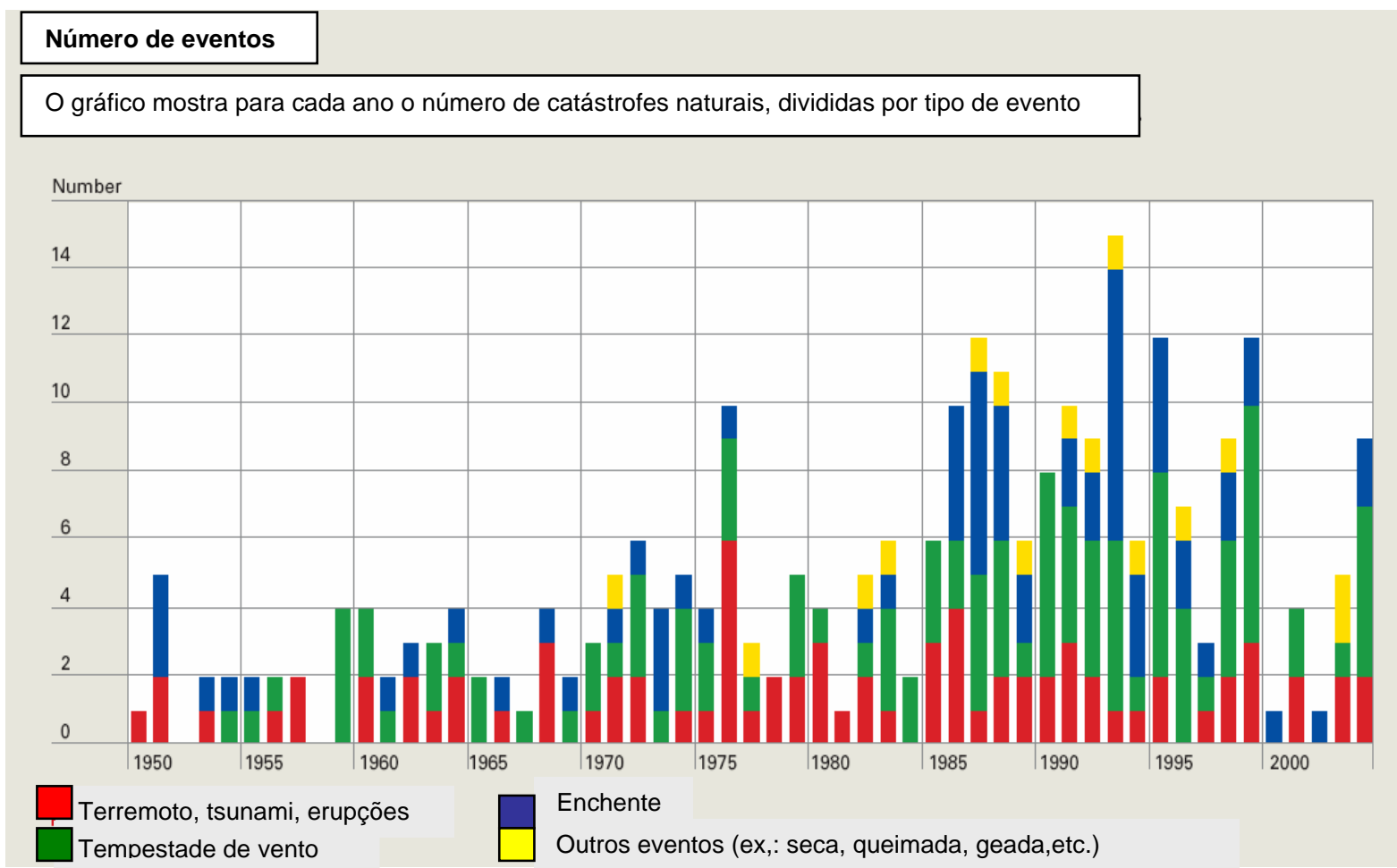

Fonte: Munich Re, Topics Geo Annual review: Catastrophes 2004. p.15.

Um exemplo da magnitude de destruição que alterações no sistema climático podem causar foi o furacão Katrina que atingiu os Estados Unidos em agosto de 2005. Os ventos do furacão alcançaram mais de 280 quilômetros por hora, e causaram grandes prejuízos na região litorânea do sul dos Estados Unidos, especialmente em torno da região metropolitana de New Orleans. O furacão passou pelo sul da Flórida, causando em torno de dois bilhões de dólares de prejuízo e aproximadamente mil mortes.

Como conseqüência da tempestade, muitos problemas apareceram. Alguns dos diques que protegiam New Orleans não conseguiram conter as águas do Lago Pontchartrain, que afluiu cidade adentro, inundando mais de $80 \%$ da 
cidade. Cerca de 200 mil casas ficaram debaixo d'água, além de danos no sistema de abastecimento sanitário e de esgoto. A maioria dos habitantes da cidade foram evacuados para outras cidades do Estado de Louisiana, Texas e Missouri, porém, muitos foram transportados para regiões distantes tais como Washington, Ontário e Illinois. A interrupção de suprimento de petróleo, importações e exportações causada pela tempestade tiveram conseqüências para a economia global.

Eventos como esses podem ocorrer e atingir locais mais pobres e sem recursos para serem reconstruídos. A cidade de New Orleans que é desenvolvida até hoje não se recuperou do desastre. Locais pobres da África, por exemplo, se sofressem esse tipo de evento climático ficariam condenadas à total destruição.

Analisando as prováveis conseqüências para a humanidade dos efeitos provocados pelas mudanças climáticas, podemos ter em mente o princípio da precaução e o conceito de segurança ambiental.

Segundo DERANI, o princípio da precaução,

“(...) indica uma atuação 'racional' para com os bens ambientais, com a mais cuidadosa apreensão possível dos recursos naturais, numa espécie de 'Daseinvorsorge' ou Zukunftvrosorge' (cuidado, precaução com a existência ou com o futuro), que vai além de simples medidas para afastar o perigo. Na verdade, é uma 'precaução contra o risco', que objetiva prevenir já uma suspeição de perigo ou garantir uma suficiente margem de segurança da linha de perigo."28

A partir da publicação do relatório Nosso Futuro Comum, no qual conceituou-se o desenvolvimento sustentável, e da publicação do primeiro relatório do IPCC, que indicou uma relação direta entre aumento de temperaturas e ações antrópicas, tendo como conseqüência mudanças climáticas, medidas têm sido tomadas para minimizar a interferência humana no planeta. Essas medidas são extremamente importantes, considerando o risco de colapso que a poluição atmosférica, o uso indiscriminado de recursos naturais, o desmatamento, podem causar às futuras gerações.

${ }^{28}$ DERANI, Cristiane. Direito Ambiental Econômico. São Paulo. Max Limonad, 2001. p. 165. 
O estabelecimento da Convenção de Mudanças Climáticas e de metas de redução das emissões de carbono para os países com as maiores porcentagens de emissões (enquadrados no Anexo I da Convenção) de Gases de Efeito Estufa corroboram o princípio da precaução. As conseqüências do aquecimento global são ainda intensamente discutidas. Na incerteza dos cenários futuros, a estratégia é prevenir os acontecimentos e evitar o risco de futuras catástrofes.

Corroborando nossas idéias, DERANI afirma que

"O princípio da precaução está ligado aos conceitos de afastamento de perigo e segurança das gerações futuras, como também de sustentabilidade ambiental das atividades humanas. Este princípio é a tradução da busca da proteção da existência humana, seja pela proteção de seu ambiente como pelo asseguramento da integridade da vida humana. A partir dessa premissa, deve-se também considerar não só o risco iminente de uma determinada atividade como também os riscos futuros decorrentes de empreendimentos humanos, os quais nossa compreensão e o atual estágio de desenvolvimento da ciência jamais conseguem captar em toda densidade."29

A partir da aplicação do princípio da precaução, as atividades humanas devem estar orientadas para a garantia de um meio ambiente sustentável. As atividades devem necessariamente ser transformadas, 0 modo de desenvolvimento econômico deve ser alterado. As melhores tecnologias devem ser aplicadas, políticas públicas que defendam o perigo ambiental, que diminuam o risco para o ambiente e que protejam as bases naturais da existência devem ser implementadas. Deve-se questionar também a necessidade de desenvolvimento e existência de atividades que coloquem em risco o meio ambiente e as futuras gerações.

Um exemplo da aplicação do princípio da precaução foi o estabelecimento do Protocolo de Kyoto - instrumento da Convenção Quadro das Nações Unidas sobre Mudanças Climáticas, adotado na COP3 realizada em Kyoto no Japão, que traz consigo a premissa de que mesmo na ausência de elevado grau de confiabilidade nas previsões, e levando-se em conta a magnitude dos efeitos

${ }^{29}$ DERANI, Cristiane. Direito Ambiental Econômico. São Paulo. Max Limonad, 2001. p. 167. 
adversos, devem ser tomadas medidas de prevenção de modo a evitar o agravamento do efeito. No Protocolo de Kyoto, as Partes do Anexo I comprometem-se com metas individuais e com vinculação legal de limitação ou redução de suas emissões de gases de efeito estufa, que representam um corte total de pelo menos 5\% em relação aos níveis de 1990 no período de 2008-2012.

As metas estabelecidas no Protocolo de Kyoto visam a diminuir a emissão dos principais gases do efeito estufa. Algumas atividades específicas no setor de mudança no uso da terra e florestas (ou seja, florestamento, desflorestamento e reflorestamento) que emitem ou removem dióxido de carbono da atmosfera também são tratadas.

A aprovação do Protocolo de Kyoto estabeleceu outros princípios, dentre os quais o da responsabilidade comum, porém diferenciada e o do poluidor pagador. O princípio da responsabilidade comum, porém diferenciada estabelece que, embora seja global o problema ambiental, caberia aos países tradicionalmente industrializados e historicamente responsáveis pelos danos ambientais, o ônus por evitar seu agravamento.

Durante o processo produtivo, além do produto a ser comercializado, são produzidas "externalidades negativas". São chamadas externalidades porque, embora resultante da produção, são recebidas pela coletividade, ao contrário do lucro que é recebido pelo produtor privado. A emissão de enxofre e gás carbônico, por exemplo, são as externalidades negativas, pois seus efeitos no meio ambiente atingem a todos. Pelo princípio do poluidor-pagador, o causador da poluição deve arcar com os custos necessários à diminuição, eliminação ou neutralização deste dano.

Corroborando nossa afirmação DERANI expõe que,

"O princípio do poluidor-pagador (Verursacherprinzip) visa à internalização dos custos relativos externos de deterioração ambiental. Tal traria como conseqüência um maior cuidado em relação ao potencial poluidor da produção, na busca de uma satisfatória qualidade do meio ambiente. Pela aplicação deste princípio, impõe-se ao 'sujeito econômico' (produtor, consumidor, transportador), que nesta relação pode causar um 
problema ambiental, arcar com os custos da diminuição ou afastamento do dano." ${ }^{30}$

Dessa forma, o Protocolo de Kyoto concretiza o princípio do poluidorpagador, pois cabe aos países desenvolvidos, o ônus de reduzir as emissões, tendo em vista que ao longo da história foram os grandes responsáveis pela emissão de GEEs durante os processos de produção e obtenção de lucro.

Aliado ao princípio da precaução está o conceito de segurança ambiental, que não está ligado à ação, mas à implementação de estratégias pelos Estados diante da perspectiva limitada para o futuro quanto aos recursos naturais.

Segundo LE PRESTRE, segurança ambiental

“(...) é entendida como a proteção do meio ambiente a longo prazo." ${ }^{31}$

As atividades humanas têm causado impactos no meio ambiente, ameaçando o desenvolvimento da vida no Planeta. Esses impactos deixaram de ter uma escala local/nacional e passaram a figurar no cenário internacional. Os Estados, responsáveis pela integridade de seus territórios e interesses, estabelecem regras internacionais para impedir danos em escala mundial, tentando realizar através de tratados a regulação e o controle das ações.

O conceito de segurança ambiental apresenta três vertentes principais: o viés político, o viés econômico e o viés técnico. Tomando por base as mudanças globais para explicar estas vertentes, temos o viés político caracterizado pela criação da Convenção Quadro das Nações Unidas sobre Mudanças Climáticas. A convenção visa a regular a ordem ambiental internacional e a garantir a segurança das nações diante de problemas ambientais decorrentes de mudanças climáticas. O viés econômico surge a partir da criação de mecanismos financeiros que possibilitam a comercialização de reduções de carbono entre países visando a atingir as premissas colocadas pela convenção de mudanças climáticas. O viés técnico surge da elaboração e publicação de inúmeros estudos sobre a questão, além da incorporação do tema em agendas políticas nacionais.

${ }^{30}$ DERANI, Cristiane. Direito Ambiental Econômico. São Paulo. Max Limonad, 2001. p. 159.

${ }^{31}$ LE PRESTE, Philippe. Ecopolítica Internacional. São Paulo, SENAC, 2000. p. 411. 
Porém, há grandes dificuldades de conciliação entre o conhecimento técnico/científico e a política, pois em muitas discussões internacionais os cientistas criticam os documentos elaborados, dizendo que os conceitos estão errados ou desprovidos de base científica que os sustentem. De outro lado, os políticos ressentem-se de informações mais precisas, ou o que é mais freqüente, "encomendam" conclusões científicas que expliquem suas decisões. Um exemplo disso são os estudos anteriormente financiados pelos Estados Unidos que apresentavam conclusões contrárias aos estudos do IPCC sobre as mudanças globais.

Dessa forma, de acordo com o interesse de cada país será aplicado o conceito de segurança ambiental. Porém, quando as vertentes acima citadas não são equilibradas, podem ocasionar conflitos entre as nações.

Reafirmando nosso pensamento podemos citar Elliott:

"Embora o estresse ambiental seja identificado não como ameaça militar, as políticas ambientais são militares, porque o elemento ameaça é definido, na análise final, não pelo impacto na segurança humana ou na segurança econômica, mas pela sua relação com os conflitos que ameaçam a segurança geopolítica de um Estado." (tradução da autora) ${ }^{32}$

Portanto, o problema não é a degradação ambiental por si só e sim quando envolve violência e segurança. Quando uma população fica exposta a um perigo de impacto à sobrevivência, pode-se justificar uma intervenção militar.

Podemos novamente citar Elliott:

"Conseqüências sociais e econômicas resultantes da degradação ambiental e da escassez de recursos, especialmente a escassez de alimentos, podem também contribuir para legitimar e autorizar determinadas relações sociais." ${ }^{33}$ (tradução da autora)

\footnotetext{
${ }^{32}$ But even though environmental stress is identified as non military threat, environmental politics are militarized because the human security or even economic security but by its relationship, through the potential for conflict, with the military and geopolitical security of the state. In: ELLIOTT, L. The Global Politics and Environment. Macmillan, 1998 p. 230.

${ }^{33}$ The social and economic consequences of environmental degradation and resources scarcity, especially food scarcity, may also contribute to a disruption in what Homer - Dixon calls 'legitimized and authoritative social relations'. In: ELLIOTT, L. The Global Politics and Environment. Macmillan, 1998 p. 227.
} 
As mudanças climáticas fornecem um exemplo de tensões que podem surgir da degradação ambiental e resultarem em catastróficas conseqüências para a segurança internacional. Aqueles países que são os mais atingidos pelos impactos das mudanças climáticas - pela mudança de temperatura, pela elevação do nível dos mares, pelas mudanças nas áreas agrícolas, pela possibilidade do aumento de condições extremas de clima, pela falta de água ou variações no regime de chuva - são os países mais pobres cujos ecossistemas já são marginais e nos quais a economia e a infra-estrutura são menos flexíveis e adaptáveis às degradações ambientais. Este cenário pode levar a um conflito direto, com invasões de fronteiras e disputa por recursos naturais.

O modo de produção capitalista no qual estamos inseridos, baseado no lucro e na exploração dos recursos humanos, aliado à sociedade "criada" para absorver essa produção são os responsáveis pelos impactos ambientais, dos quais destacamos as mudanças climáticas. Dessa forma, devemos nos preocupar com a espécie humana, com a base material para sua reprodução, garantia de futuro e segurança. Para reverter e/ou minimizar esses impactos, as mudanças de paradigma da exploração dos recursos naturais devem ser primordiais e em escala global. Para que isso ocorra políticas de conciliação de interesses, traduzidas em regulamentações entre os Estados, são necessárias. A Convenção Quadro de Mudanças Climáticas é um exemplo dessa convergência de interesses visando a manutenção da segurança ambiental.

No capítulo 2, Mudanças Climáticas e a Convenção Quadro das Nações Unidas sobre Mudanças Climáticas, discutiremos as mudanças climáticas, suas conseqüências, o tratado estabelecido pelas Nações Unidas e seu panorama histórico, principais objetivos, mecanismos criados para sua implementação. 


\section{CAPÍTULO 2: MUDANÇAS GLOBAIS E A CONVENÇÃO QUADRO DAS NAÇÕES UNIDAS SOBRE MUDANÇAS CLIMÁTICAS (CQNUMC)}

Neste capítulo relataremos o panorama histórico do surgimento da Convenção Quadro das Nações Unidas sobre Mudanças Climáticas. Além disso, serão analisados os relatórios publicados pelo International Panel on Climate Change e as principais decisões das Conferências das Partes.

A publicação do Relatório Nosso Futuro Comum, em 1987, difundiu que a acumulação dos gases de efeito estufa (GEE) na atmosfera era indicada como um risco para o planeta, sendo sua mais grave conseqüência o aumento da média de temperatura da Terra.

Com as publicações dos relatórios do International Panel on Climate Change - IPCC, indicando a interferência humana no sistema climático e as desastrosas conseqüências para a sobrevivência no planeta, foi adotada em maio de 1992, a Convenção Quadro das Nações Unidas sobre Mudanças Climáticas. A Conferência das Partes, composta por todos os países que assinaram/ratificaram a Convenção, é responsável por sua implementação visando a atingir o objetivo final da Convenção que é a estabilização das concentrações de gases de efeito estufa na atmosfera, em um nível que impeça uma interferência antrópica perigosa no sistema climático.

A Conferência das Partes adotou o Protocolo de Kyoto que estabelece metas de redução das emissões de gases de efeito estufa aos países do Anexo $1^{34}$, adotando dessa forma, o princípio das responsabilidades comuns porém diferenciadas.

Diante deste panorama, apresentaremos neste capítulo o processo de construção da Convenção e seus desdobramentos, nas Conferências das Partes.

34 O Anexo I da Convenção é composto pelos países que historicamente possuem maiores índices de emissões de Gases de efeito estufa: Alemanha, Austrália, Áustria Bélgica, BieloRússia*, Bélgica, Bulgária, Canadá, Comunidade Européia, Croácia, Dinamarca, Eslováquia, Eslovênia, Espanha, Estados Unidos, Estônia, Federação Russa, Finlândia, França, Grécia, Hungria, Irlanda, Islândia, Itália, Japão, Letônia, Liechtenstein, Lituânia, Luxemburgo, Mônaco, Noruega, Nova Zelândia, Países Baixos, Polônia, Portugal, Reino Unido da Grã-Bretanha e Irlanda do Norte, República Tcheca, Romênia, Suécia, Suíça, Turquia e Ucrânia. 


\subsection{As mudanças climáticas e os relatórios do International Panel on Climate Change (IPCC)}

A Terra deve irradiar energia para o espaço na mesma proporção em que a absorve do sol para manter o equilíbrio térmico. A energia solar chega na forma de radiação de ondas curtas. Parte dessa radiação é absorvida e/ou refletida (por partículas em suspensão, moléculas de ar e nuvens) de volta para o espaço na atmosfera. A maior parte dela, contudo, passa diretamente pela atmosfera para aquecer a superfície terrestre. A Terra se livra dessa energia, mandando-a de volta para o espaço, na forma de irradiação infravermelha de ondas longas.

A maior parte da irradiação infravermelha que a superfície da Terra emite é absorvida pelo vapor d'água, pelo dióxido de carbono e outros gases de efeito estufa que existem naturalmente na atmosfera. Do ponto de vista puramente radiativo, atmosfera perde mais energia em onda longa que absorve. Portanto, a atmosfera sofre um processo de resfriamento radiativo por perda de energia por onda longa, enquanto a superfície terrestre sofre aquecimento por absorção de onda curta. Para manter o equilíbrio térmico do sistema superfície/atmosfera é preciso transferir calor da superfície para a atmosfera. Essa transferência de energia se dá através das correntes de ar que transportam calor para cima; das nuvens que aquecem a atmosfera no processo de condensação do vapor d'água, da evaporação na superfície (que resfria o solo e a vegetação) e da troca de calor na superfície por condução. O efeito estufa, portanto, é benéfico para a vida na Terra. Sem ele, a superfície seria muito mais fria.

O sistema climático terrestre vem sendo alterado pelas atividades antrópicas principalmente através do aumento da concentração dos GEEs, o que efetivamente causa um aumento de temperatura. A maior concentração de GEEs aumenta a capacidade da atmosfera de absorver irradiação infravermelha. Portanto, nossas emissões de gases de efeito estufa estão perturbando a forma com que o clima mantém o equilíbrio entre a energia que entra e a energia que sai do sistema. Uma duplicação, na atmosfera, da quantidade de gases de efeito estufa reduziria em $2 \%$, se nada fosse mudado, a proporção em que o planeta é capaz de irradiar energia para o espaço. 
As atividades humanas liberam gases de efeito estufa, por exemplo, quando queimamos carvão, petróleo e gás natural, liberamos quantidades enormes de dióxido de carbono no ar. Esse carbono, estocado nos combustíveis fósseis foi armazenado nas profundezas da Terra há centenas de milhões de anos e agora está sendo liberado em curto tempo (principalmente desde o início da Era Industrial). Mas a mudança da cobertura terrestre também pode contribuir para o aumento da concentração de GEEs. Quando florestas são destruídas, o carbono armazenado nas árvores escapa para a atmosfera. Outras atividades básicas, como a criação de gado e o cultivo de arroz, emitem metano, óxido nitroso e outros gases de efeito estufa.

O que se verifica hoje é um agravamento/aceleração dessas emissões provocadas pela ação antrópica, principalmente com a intensa atividade industrial que resulta em emissões de grandes quantidades de gases de efeito estufa. Cerca de $85 \%$ das emissões medias globais são oriundas da queima de combustível fóssil enquanto $15 \%$ provém da mudança de uso do solo e atividades agrícolas.

"As mudanças verificadas no clima atual decorrem de emissões do passado. A Revolução Industrial, quando se iniciou em larga escala o uso de combustíveis fósseis para gerar energia e mover máquinas e motores, é apontada freqüentemente como o momento de ruptura, um marco na necessária periodização da emissão de gases-estufa resultantes da ação humana". ${ }^{35}$

As questões ambientais relacionadas à mudança do clima surgiram na agenda política em meados da década de 80 e ganharam maior visibilidade na cena internacional em 1987, por ocasião da publicação do relatório da exprimeira-ministra norueguesa Gro Harlem Brundtland para a Comissão Mundial sobre o Meio Ambiente e o Desenvolvimento das Nações Unidas. Neste relatório, denominado Nosso futuro comum, a acumulação dos gases de efeito estufa (GEE) na atmosfera era indicada como um risco para o planeta, sendo sua mais grave conseqüência o aumento da média de temperatura da Terra.

${ }^{35}$ RIBEIRO, W.C. Mudanças Climáticas, realismo e multilateralismo. Revista Terra Livre. São Paulo, ano 18, vol. I, n 18 - p. 75-84, 2002. 
Apesar da gravidade da denúncia, não havia então conhecimento científico capaz de verificar sua validade. Com este fim, em 1988, a Organização Meteorológica Mundial (OMM) e o Programa das Nações Unidas para o Meio Ambiente (PNUMA) criaram o Intergovernmental Panel on Climate Change (IPCC), formado por uma equipe de especialistas internacionais que deveria: identificar as incertezas e lacunas no conhecimento atual com relação às mudanças climáticas e seus potenciais impactos, e preparar um plano de ação para cobrir essas lacunas; identificar informações necessárias para avaliar implicações políticas das mudanças climáticas e estratégias de resposta a essas implicações; revisar os planos nacionais e internacionais relacionadas aos gases de efeito estufa; e avaliar os aspectos científicos e ambientais das emissões de gases de efeito estufa e disponibilizar aos governos e organizações nãogovernamentais para levar em consideração em suas políticas sociais e econômicas e programas ambientais.

O IPCC estabeleceu três grupos de trabalho que preparariam avaliações nas seguintes vertentes:

- Working Group I (WGI): estuda os aspectos científicos do sistema climático e da mudança climática;

- Working Group II (WGII): avalia a vulnerabilidade da humanidade e dos sistemas naturais às mudanças climáticas, suas conseqüências positivas e negativas e as opções para a adaptação necessária a estas conseqüências;

- Working Group III (WGIII): analisa as possibilidades de limitação da emissão de GEEs e de mitigação da mudança climática e as conseqüências destas medidas do ponto de vista sócioeconômico.

O primeiro relatório foi publicado em 1990, no qual os grupos de trabalho apresentaram as seguintes conclusões:

"Os especialistas estão certos de que as emissões das atividades humanas estão aumentando substancialmente as concentrações de gases de efeito estufa na atmosfera e que isso realçará os efeitos desses gases e 
resultará no aumento adicional na temperatura da superfície da Terra. Os modelos disponíveis indicam um aumento global da temperatura durante o século 21 de $0,3^{\circ} \mathrm{C}$ por década com uma escala incerta de $0,2^{\circ} \mathrm{C}$ a $0,5^{\circ} \mathrm{C}$, e um aumento global do nível do mar de $6 \mathrm{~cm}$ por década com uma escala variável de 3 a $10 \mathrm{~cm}$ por década." (tradução da autora) ${ }^{36}$

Além dessas conclusões, os cientistas assinalaram importantes incertezas quanto ao tempo, magnitude e padrões regionais das mudanças climáticas, mas notaram que os impactos serão maiores em regiões já sob stress climático, principalmente em países em desenvolvimento.

Os principais gases estufa liberados durante a queima de combustíveis fósseis e atividades humanas são o dióxido de carbono $\left(\mathrm{CO}_{2}\right)$, metano $\left(\mathrm{CH}_{4}\right)$, óxido nitroso $\left(\mathrm{N}_{2} \mathrm{O}\right)$, hidrofluorcarbonos (HFCs), perfluorcarbonos (PFCs) e hexafluoreto de enxofre $\left(\mathrm{SF}_{6}\right)$.

O dióxido de carbono é resultante da queima de combustíveis fósseis (carvão, petróleo) e pelo desflorestamento. É o gás em maior quantidade na atmosfera. O metano é emitido pelo cultivo de arroz, por animais domesticados, como o gado, e pela disposição e tratamento de lixo e resíduos humanos. O óxido nitroso é emitido principalmente como resultado do uso de fertilizantes. Os HFCs e PFCs estão sendo adotados como substitutos dos CFCs por não afetarem a camada de ozônio. O hexafluoreto de enxofre é utilizado como isolante elétrico, condutor de calor e agente refrigerante. Molécula por molécula, acredita-se que o seu potencial de aquecimento global seja 23.900 vezes maior que o do dióxido de carbono.

Os gráficos e tabelas a seguir indicam a contribuição de cada um dos GEEs para o aquecimento global, seus efeitos e respectivos potenciais de aquecimento e as atividades que são responsáveis por suas emissões em 1990.

\footnotetext{
36 The experts concluded that they are certain that emissions from human activities are substantially increasing the atmospheric concentrations of greenhouse gases and that this will enhance the greenhouse effect and result in an additional warming of the Earth's surface. Models available at that time predicted under business as usual a rate of increase of the global mean temperature during the 21st century of $0.3{ }^{\circ} \mathrm{C}$ per decade with an uncertainty range of $0.2^{\circ} \mathrm{C}$ to $0.5^{\circ} \mathrm{C}$, and an increase of the global mean sea level of $6 \mathrm{~cm}$ per decade with an uncertainty range of 3 to $10 \mathrm{~cm}$ per decade. In: IPCC. 16 Years of Scientific Assessment in Support of the Climate Convention, December 2004. p. 03.
} 
Gráfico 2: Contribuição dos GEE para o aquecimento global - 1990

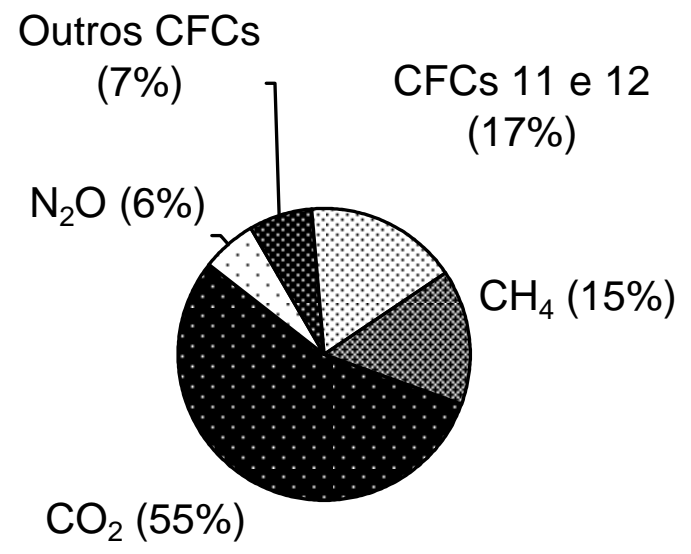

Fonte: Lashof \& Tripak, 1990. In GALVÃO, L.C.R.; GRIMONI, J.A.B.; UDAETA, M.E.M. (Org.) Iniciação a Conceitos de sistemas Energéticos para o Desenvolvimento Limpo. - São Paulo: Editora da Universidade de São Paulo, 2004. p. 43.

\section{Tabela 1: Os principais gases GEE e seus efeitos - 1990}

\begin{tabular}{|c|c|c|c|c|c|c|}
\hline Gás & Fórmula & $\begin{array}{c}\text { Concentração na } \\
\text { era pré-industrial } \\
\text { (ppbv) }\end{array}$ & $\begin{array}{c}\text { Concentração } \\
\text { em } 1994 \\
\text { (ppbv) }\end{array}$ & $\begin{array}{c}\text { Tempo de vida } \\
\text { na atmosfera } \\
\text { (ano) }{ }^{\star \star \star}\end{array}$ & Fonte de produção & $\begin{array}{l}\text { Potencial de } \\
\text { aquecimento } \\
\text { global } \\
\text { (GWP)* }\end{array}$ \\
\hline $\begin{array}{l}\text { Dióxido } \\
\text { de } \\
\text { carbono }\end{array}$ & $\mathrm{CO}_{2}$ & 278.000 & 358.000 & Variável & $\begin{array}{c}\text { Queima de } \\
\text { combustível fóssil } \\
\begin{array}{c}\text { Alteração no uso da } \\
\text { terra }\end{array}\end{array}$ & 1 \\
\hline & & & & & $\begin{array}{l}\text { Produção de cimento } \\
\text { Combustíveis fósseis }\end{array}$ & \\
\hline Metano & $\mathrm{CH}_{4}$ & 700 & 1.721 & $12,2+-3$ & $\begin{array}{l}\text { Plantação de arroz } \\
\text { Aterros sanitários } \\
\text { Criação de gado }\end{array}$ & $21^{\star *}$ \\
\hline
\end{tabular}




\begin{tabular}{|c|c|c|c|c|c|c|}
\hline $\begin{array}{l}\text { Óxido } \\
\text { Nitroso }\end{array}$ & $\mathrm{N}_{2} \mathrm{O}$ & 275 & 311 & 120 & $\begin{array}{l}\text { Combustão na } \\
\text { produção de } \\
\text { fertilizantes }\end{array}$ & 310 \\
\hline & & & & & $\begin{array}{l}\text { Fluido para } \\
\text { refrigeração }\end{array}$ & \\
\hline CFC 12 & $\mathrm{CCl}_{2} \mathrm{~F}_{2}$ & 0 & 0,503 & 102 & Espuma & $\begin{array}{c}6.200- \\
7.100 \text { - }\end{array}$ \\
\hline HCFC22 & $\mathrm{CHClF}_{2}$ & 0 & 0,105 & 12,1 & $\begin{array}{l}\text { Fluido para } \\
\text { refrigeração }\end{array}$ & $\begin{array}{c}1.300- \\
1.400^{\star \star \star \star}\end{array}$ \\
\hline $\begin{array}{l}\text { Perfluor- } \\
\text { metano }\end{array}$ & $\mathrm{CF}_{4}$ & 0 & 0,070 & 50.000 & $\begin{array}{l}\text { Produção de } \\
\text { alumínio }\end{array}$ & 6.500 \\
\hline $\begin{array}{l}\text { Hexa- } \\
\text { fluoreto }\end{array}$ & & & & & & \\
\hline enxofre & $\mathrm{SF}_{6}$ & 0 & 0,032 & 3.200 & Fluido dielétrico & 23.900 \\
\hline
\end{tabular}

Notas: ppbv = partes por bilhão por volume

* GWP (Global Potencial Warming) para um horizonte de cem anos

** Inclui efeitos indiretos da produção de ozônio na troposfera e produção de vapor de água na estratosfera.

*** Não se pode definir o tempo de vida para o CO2 em razão de diferentes taxas de fixação do gás por diferentes processos (IPCC SAR, p. 15)

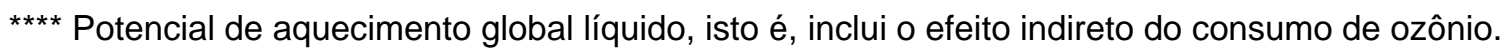

Fonte: UNEP-GRID / Arendal. In GALVÃO, L.C.R.; GRIMONI, J.A.B.; UDAETA, M.E.M. (Org.) Iniciação a Conceitos de sistemas Energéticos para o Desenvolvimento Limpo. - São Paulo: Editora da Universidade de São Paulo, 2004. p. 43. 
Gráfico 3: Contribuições das fontes de degradação ambiental para o efeito estufa - 1990

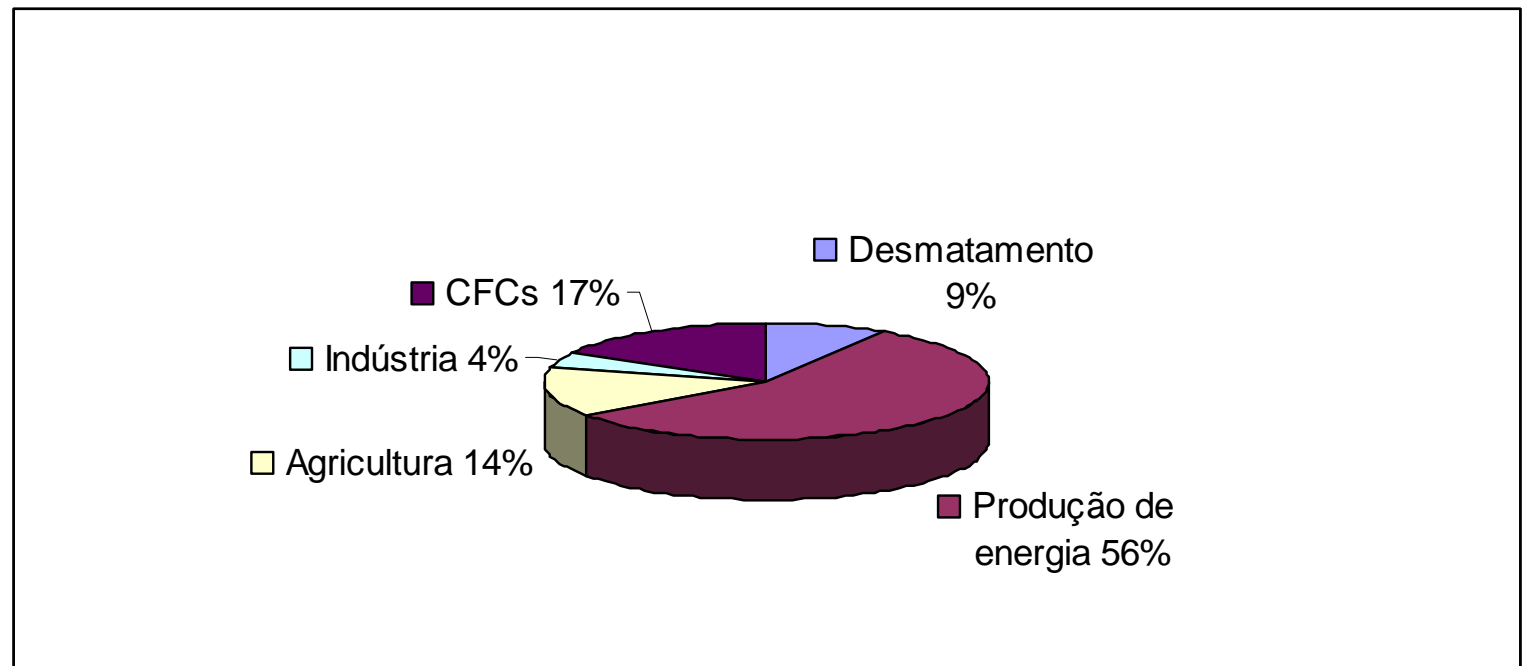

Fonte: Lashof \& Tirpak, 1990. In: GALVÃO, L.C.R.; GRIMONI, J.A.B.; UDAETA, M.E.M. (Org.) Iniciação a Conceitos de sistemas Energéticos para o Desenvolvimento Limpo. - São Paulo: Editora da Universidade de São Paulo, 2004.p.55

Assim, a tese científica segundo a qual a ação do homem tem efeitos sobre o aquecimento global foi reforçada pelas conclusões dos estudos. Isso criou as condições políticas para uma ação global de controle das emissões dos GEE.

Adotada pela Assembléia Geral das Nações Unidas em Nova York em 9 de maio de 1992, e assinada no âmbito da "Cúpula da Terra", durante a Conferência das Nações Unidas sobre o Meio Ambiente e o Desenvolvimento (ECO-92), ocorrida no Rio de Janeiro em junho do mesmo ano, a ConvençãoQuadro das Nações Unidas sobre Mudança do Clima (CQMC) entrou em vigor no dia 21 de março de 1994. Abordaremos a CQMC em detalhes mais adiante.

O segundo relatório publicado em 1995 complementa e atualiza as informações contidas no primeiro relatório, incorporando os avanços feitos na quantificação dos efeitos climáticos dos aerossóis, porém sem alterar as conclusões do relatório de 1990:

- As concentrações de gases de efeito estufa continuaram a crescer;

- Os aerossóis tendem a produzir efeitos negativos;

- O clima tem mudado ao longo do século; 
- O balanço de evidências sugere a influência humana no clima global;

- É esperado que o clima continue a mudar no futuro;

- Existem ainda muitas incertezas;

- Muitos ecossistemas são sensíveis às mudanças climáticas;

- Impactos são difíceis de quantificar, e os estudos existentes têm o escopo limitado;

- O sucesso da adaptação depende dos avanços tecnológicos, acordos institucionais, disponibilidade de financiamentos e troca de informações;

- Mais pesquisas e monitoramento são essenciais.

O terceiro relatório publicado em 2001 forneceu projeções de concentrações futuras de GEE na atmosfera, padrões de mudanças globais e regionais, taxas de alterações na temperatura, precipitação, nível do mar, e mudanças em eventos extremos. Além de uma análise biofísica e sócioeconômica dos impactos das mudanças climáticas em diferentes cenários. E as conclusões foram ainda mais drásticas, sinalizando aumentos ainda maiores de temperaturas e conseqüências mais graves:

- A média global da temperatura da superfície terrestre aumentou cerca de $0,6^{\circ} \mathrm{C}$ no século 20 . A década de 90 foi a mais quente do século, conforme apresentado nos gráficos abaixo. 
Figura 1: Variações na temperatura da superfície da Terra

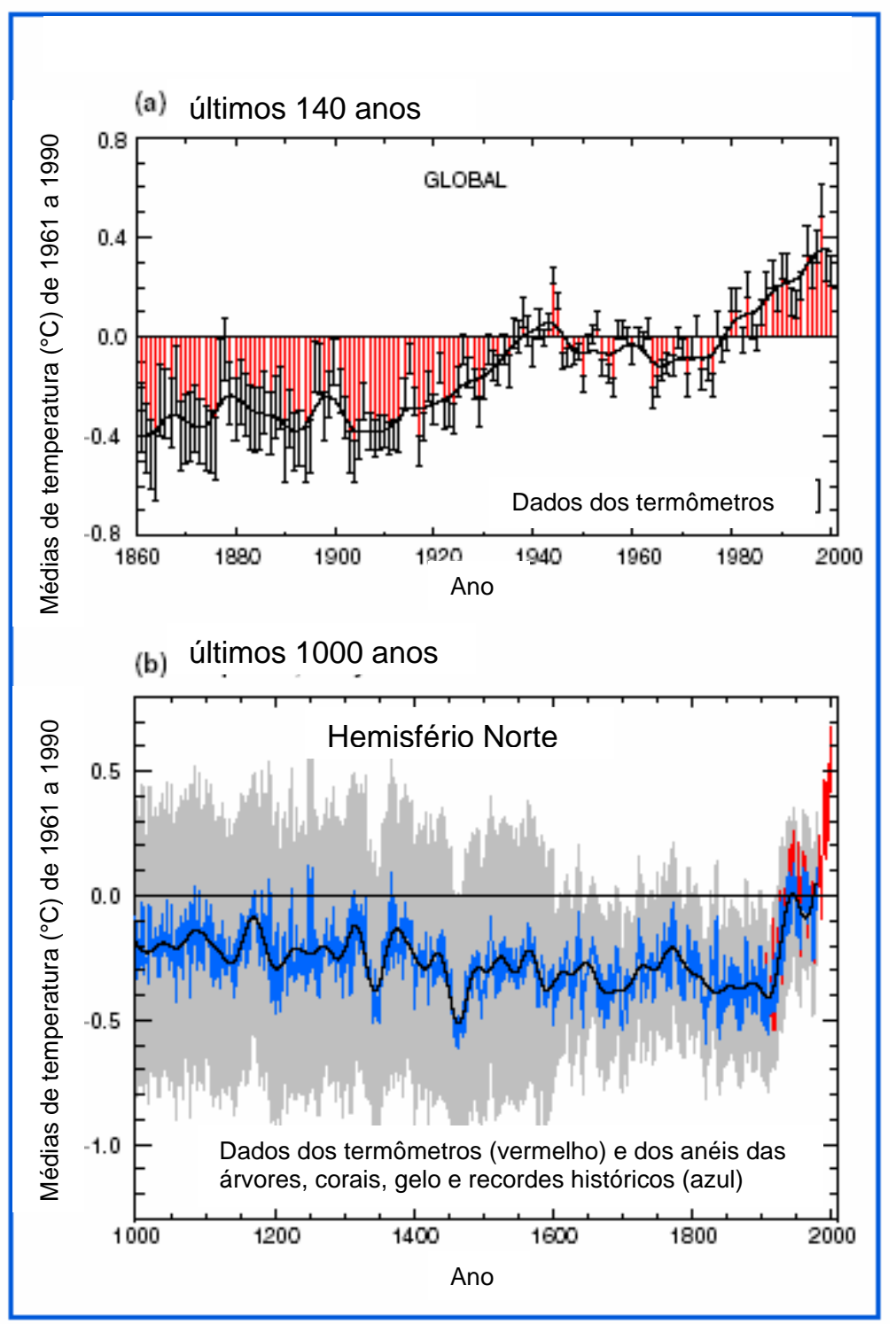

Fonte: IPCC. Climate Change 2001: Synthesis Report - Summary for Policymakers. A Report of Working Group I of the IPCC. p.3

- A media global de aumento do nível do mar foi entre 0,1 e 0,2 metros durante o século 20;

- Emissões de gases de efeito estufa e aerossóis, resultantes de atividades humanas, continuam a alterar a atmosfera. A concentração de dióxido de carbono tem aumentado 31\% desde 
1750, início da Era Industrial. Cerca de 3/4 das emissões antrópicas de dióxido de carbono durante os últimos 20 anos provém de combustíveis fósseis. As concentrações de metano aumentaram cerca de $151 \%$ desde 1750 e continuam a subir. Esses dados podem ser verificados nos gráficos abaixo.

Figura 2: Indicadores da influência humana na atmosfera durante a Era Industrial

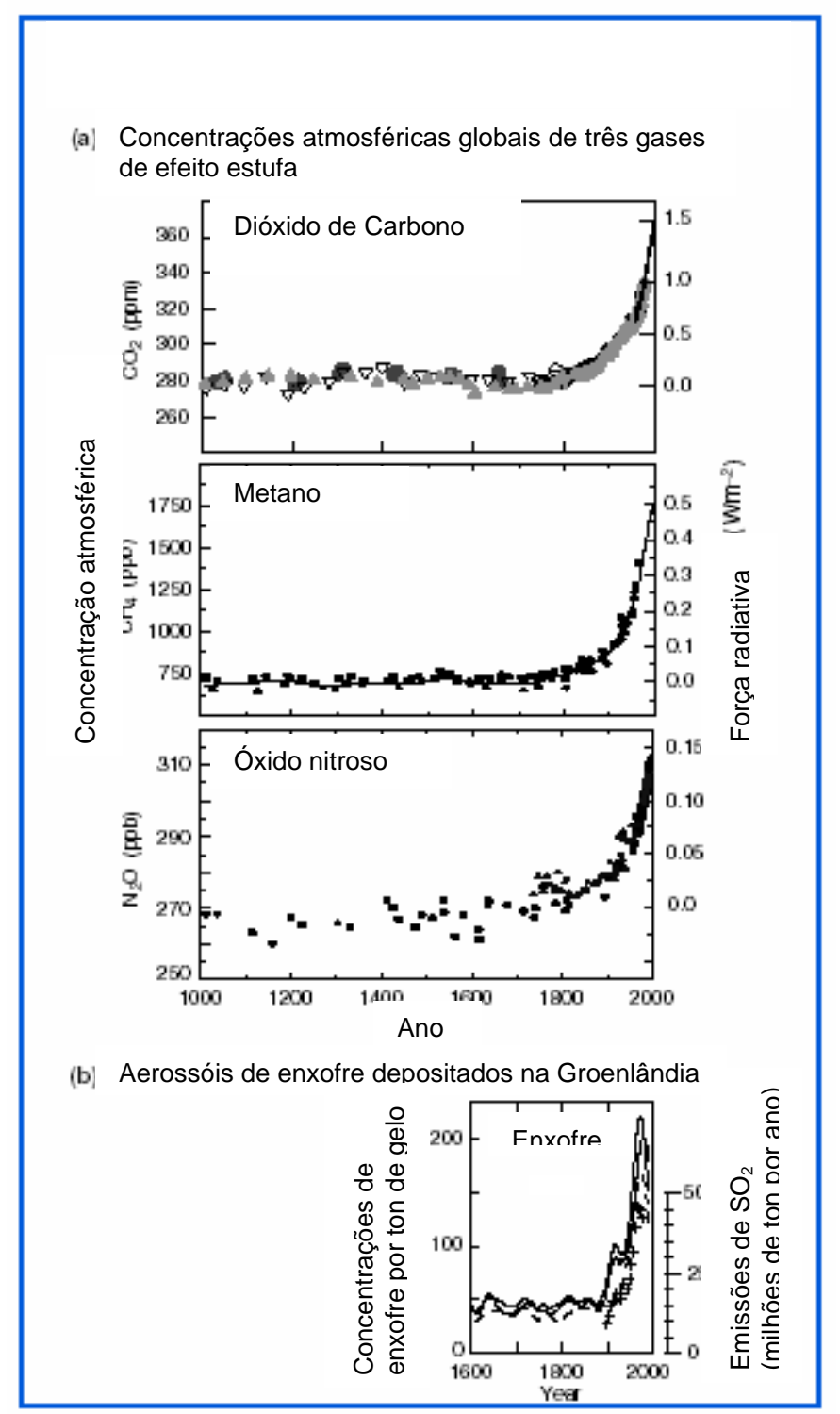

Fonte: IPCC. Climate Change 2001: Synthesis Report - Summary for Policymakers. A Report of Working Group I of the IPCC. p.6 
A aplicação de modelos mais precisos e confiáveis projetou o aumento da temperatura, no período de 1990 a 2100 , entre 1,4 a $5,8{ }^{\circ} \mathrm{C}$. Esse aquecimento traria profundos impactos ambientais, sociais e econômicos em todas as regiões do globo, conforme ilustra a tabela 2 abaixo. Esses impactos têm uma dimensão variável dependendo da região, pois as medidas de contenção dos mesmos diferem de acordo com as medidas adotadas e a realidade econômica de cada país. Portanto, países mais pobres tendem a sofrer muito mais com os impactos.

\section{Tabela 2: Impactos das mudanças climáticas}

\section{Região}

1) África

2) Ásia

3) Austrália e Nova Zelândia

4) Europa

5) América Latina

\section{Prováveis impactos}

a) diminuição da produção agrícola

b) diminuição da disponibilidade de água na região do Mediterrâneo e em países do Sul

c) aumento dos vetores de diversas doenças

d) aumento da desertificação

e) extinção de animais e plantas

a) diminuição da produção agrícola

b) diminuição da disponibilidade de água nas regiões áridas e semi-áridas

c) aumento do nível do mar deverá deslocar dezenas de milhões de pessoas

a) diminuição da disponibilidade de água

b) extinção de animais e plantas

a) desaparecimento das geleiras nos Alpes

b) aumento da produção agrícola em algumas regiões

c) impactos no turismo

a) diminuição da produção agrícola

b) aumento dos vetores de diversas doenças

c) extinção de animais e plantas 
6) América do Norte

a) aumento da produção agrícola

b) aumento dos vetores de diversas doenças

7) Polar

a) diminuição da calota polar

b) extinção de animais e plantas

8) Pequenas ilhas

a) aumento do nível do mar deverá deslocar dezenas de milhões de pessoas

b) diminuição da disponibilidade de água

c) diminuição da atividade pesqueira

d) diminuição do turismo

Fonte: ROCHA, M.T. Aquecimento global e o mercado de carbono: uma aplicação do modelo CERT. Tese apresentada para obtenção do título de doutor. Escola superior de agricultura Luiz de Queiroz. Piracicaba, 2003. p. 5

O quarto relatório do IPCC divulgado em fevereiro de 2007, assinado por 2.500 cientistas de 153 países diferentes, conclamados pelas Nações Unidas, confirma que o planeta está esquentando de maneira irreversível.

"Evidências de todos os continentes e oceanos mostram que muitos sistemas naturais estão sendo afetados por mudanças climáticas regionais, particularmente por aumentos de temperatura" ${ }^{37}$.(tradução da autora)

"Avaliações globais de dados desde 1970 têm mostrado que é provável (mais de $66 \%$ de certeza) que o aquecimento provocado pela ação humana tenha influência em muitos sistemas físicos e biológicos"38 (tradução da autora)

${ }^{37}$ Fonte: IPCC. Climate Change 2007: Climate Change Impacts, Adaptation and Vulnerability. Summary for Policymakers. Disponível em: http://ipcc-wg1.ucar.edu/wg1/wg1-report.html p. 02. Acessado em 05/02/2007.

${ }^{38}$ Fonte: IPCC. Climate Change 2007: Climate Change Impacts, Adaptation and Vulnerability. Summary for Policymakers. p. 03. Disponível em: : http://ipcc-wg1.ucar.edu/wg1/wg1-report.html p. 02 . Acessado em 05/02/2007. 
O aquecimento do sistema climático não é um equívoco, sendo agora evidente de acordo com as observações de aumento global do ar e das temperaturas dos oceanos, derretimento de gelo e neve em larga escala, e aumento global do nível dos oceanos. Onze dos últimos doze anos (1995-2006) estão entre os mais quentes desde os registros instrumentais da temperatura da superfície global.

Observações feitas desde 1961 têm mostrado que a temperatura dos oceanos tem crescido em profundidades de até $3.000 \mathrm{~m}$ e que os oceanos têm absorvido mais que $80 \%$ do calor acrescido ao sistema climático. As geleiras e as coberturas das montanhas com neve têm declinado em ambos os hemisférios. $A$ diminuição das geleiras e das calotas polares têm contribuído para o aumento do nível do mar. Novos dados mostram que as perdas das camadas de gelo da Antártica e da Groenlândia contribuíram para o aumento do nível do mar. Calculase que o nível do mar global aumentou em uma taxa média de 1,8mm por ano, entre 1961-2003. A taxa foi mais rápida de 1993-2003, com cerca de 3,1mm por ano. O aumento do nível do mar coloca em risco a existência de inúmeras cidades litorâneas e de ilhas. A Indonésia, por exemplo, poderá perder cerca de duas mil ilhas até 2030 devido ao aumento do nível dos oceanos.

Secas mais longas e intensas têm sido observadas em áreas cada vez maiores desde a década de 1970, principalmente nas regiões tropicais e subtropicais. Aumento do clima seco devido ao aumento de temperatura e à diminuição da precipitação tem contribuído para as mudanças da seca. Mudanças na temperatura da superfície do mar, padrões de ventos e a diminuição da queda de neve e da cobertura de neve também têm contribuído para as secas. A freqüência de precipitações fortes tem aumentado sobre a maioria das regiões continentais, consistente com aquecimento e com o aumento observado de vapor d'água na atmosfera. Mudanças nas temperaturas extremas também têm sido observadas em todos os lugares durante os últimos 50 anos. Dias frios, noites frias e geadas estão diminuindo enquanto as ondas de calor tem sido mais freqüentes. Há uma evidência observada sobre o aumento da intensidade da atividade dos ciclones tropicais no Atlântico norte desde 1970, relacionando este aumento com o aumento da temperatura da superfície do mar tropical. 
Para as próximas duas décadas é estimado um aquecimento de $0,2^{\circ} \mathrm{C}$ por década. Mesmo que a concentração de todos os gases estufas e aerossol fossem mantidos constantes no nível do ano de 2000, um aquecimento além de cerca de $0,1^{\circ} \mathrm{C}$ por década seria esperado.

A continuidade na emissão do gás estufa na taxa atual ou maior causaria um aquecimento extra e induziria muitas mudanças no sistema climático global durante o século 21, e muito provavelmente estas mudanças seriam muito mais impactantes do que aquelas observadas no século 20 :

- Concentrações crescentes de dióxido de carbono na atmosfera levam à crescente acidificação do oceanos;

- Espera-se que o aquecimento seja maior sobre a terra e em latitudes mais altas;

- A cobertura de neve se contrai. Aumentos generalizados na profundidade do degelo estão previstos sobre a maioria das regiões com camadas permanentemente congeladas;

- O gelo marítimo vai encolher em ambos os pólos. Em algumas previsões, o gelo marítimo de final de verão ártico desaparece completamente até o final do século 21;

- É muito provável que casos de picos de temperaturas, ondas de calor e alta precipitação continuem a ocorrer frequentemente;

- É possível que ciclones tropicais futuros (tufões e furacões) se tornem mais violentos, com picos de velocidade de ventos maiores e precipitação mais pesada associada com contínuos aumentos tropicais;

- Estima-se que as rotas de tempestades extratropicais se movam em direção aos pólos, com conseqüentes alterações dos padrões de vento, precipitação e temperatura;

- O aquecimento antropogênico e a elevação do nível do mar continuariam por muitos séculos, em decorrência das escalas de tempo associadas a processos e correções climáticas, mesmo se as concentrações de gases poluentes fossem estabilizadas. 
As conseqüências do aquecimento global podem ser sentidas em todo o planeta. O estabelecimento de estratégias políticas para prevenir e reverter esse quadro exige uma resposta internacional. A Convenção Quadro das Nações Unidas sobre Mudanças Climáticas que discutiremos a seguir, é uma resposta a ele.

\subsection{A Convenção Quadro das Nações Unidas sobre Mudanças Climáticas}

O aumento da evidência científica sobre a interferência humana no sistema climático e a crescente preocupação pública com as questões ambientais globais colocaram a mudança do clima na agenda política na segunda metade da década de oitenta. A preocupação acerca de uma possível mudança no padrão de funcionamento do sistema climático possibilitou a realização, em Toronto, no Canadá, da Conferência Mundial sobre Mudanças Atmosféricas - The Changing Atmosphere: Implications for Global Security, na qual se sugeriu a adoção rápida de uma convenção internacional sobre mudança climática.

Reconhecendo a necessidade de informações científicas confiáveis e atualizadas para os formuladores de políticas, do elevado risco trazido pelas mudanças no sistema climático e da necessidade de uma fonte objetiva de informações sobre as causas e impactos da mudança climática, a Organização Meteorológica Mundial (OMM) e o Programa das Nações Unidas para o Meio Ambiente (PNUMA) estabeleceram o International Panel on Climate Change (IPCC) em 1988. Nesse mesmo ano, seguindo uma proposta do Governo de Malta, a Assembléia Geral das Nações Unidas abordou o tema da mudança do clima pela primeira vez e adotou a resolução 43/53 sobre a "Proteção do clima global para as gerações presentes e futuras da humanidade". A resolução reconheceu que as alterações climáticas constituem um interesse comum da humanidade, e determinou que se deveria prontamente tomar iniciativa para lidar com elas em um âmbito global.

Em 1990, o IPCC lançou o seu Primeiro Relatório de Avaliação, confirmando que a mudança do clima era, de fato, uma ameaça e incitando à negociação de um acordo global para tratar do problema. Esse chamado repercutiu na Declaração Ministerial da Segunda Conferência Mundial do Clima, 
realizada em Genebra, em outubro/novembro desse ano. A Assembléia Geral das Nações Unidas respondeu a esses apelos em dezembro de 1990, lançando formalmente negociações relativas a uma convenção-quadro sobre mudança do clima por meio da resolução 45/212 e estabelecendo um Comitê Intergovernamental de Negociação (CIN) para conduzir essas negociações.

O CIN reuniu-se pela primeira vez em fevereiro de 1991. Depois de apenas 15 meses e cinco reuniões com a participação de 150 países, o CIN adotou por consenso a Convenção-Quadro das Nações Unidas sobre Mudança do Clima no dia 2 de maio de 1992. A Convenção foi aberta a assinaturas na Conferência das Nações Unidas sobre Meio Ambiente e Desenvolvimento (CNUMAD), a chamada "Cúpula da Terra", no Rio de Janeiro, em 4 de junho de 1992 e entrou em vigor no dia 21 de março de 1994. O texto sobre o controle da emissão de gases estufa adotado na Convenção sobre Mudanças Climáticas foi genérico, resultado de uma pressão dos Estados Unidos e países produtores de petróleo na salvaguarda de seus interesses.

Hoje, 173 países são Partes da Convenção ${ }^{39}$. Para tornar-se Parte, o país deve ratificar, aceitar, aprovar a Convenção ou a ela ceder. No Brasil, a convenção foi ratificada pelo Congresso em 28 de fevereiro de 1994 e entrou em vigor 90 dias após esta data, ou seja, no dia 29 de maio.

O objetivo da Convenção está explícito em seu Artigo 2:

"O objetivo final desta Convenção e de quaisquer instrumentos jurídicos com ela relacionados que adote a Conferência das Partes é o de alcançar, em conformidade com as disposições pertinentes desta Convenção, a estabilização das concentrações de gases de efeito estufa na atmosfera num nível que impeça uma interferência antrópica perigosa no sistema climático. Esse nível deverá ser alcançado num prazo suficiente que permita aos ecossistemas adaptarem-se naturalmente à mudança do clima, que assegure que a produção de alimentos não seja ameaçada e que permita ao desenvolvimento econômico prosseguir de maneira sustentável." ${ }^{40}$

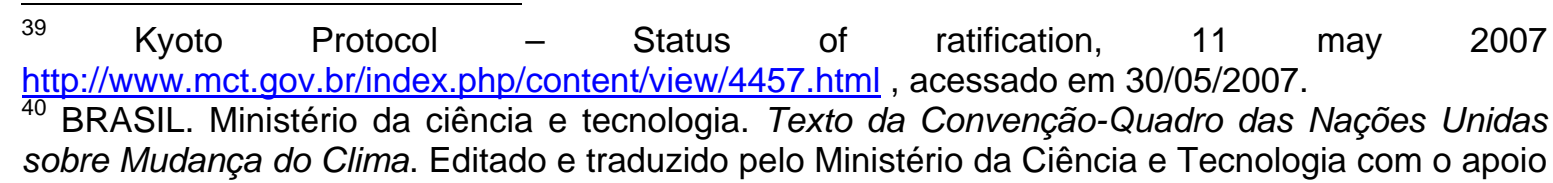


Para que o objetivo da Convenção fosse atingido, estabeleceu-se uma série de instituições para governar, administrar e dar suporte ao processo de discussão sobre as mudanças climáticas.

Além do Comitê Intergovernamental de Negociação, a Convenção estabeleceu a Conferência das Partes (COP), que é a autoridade máxima para tomadas de decisões. A COP é composta por todos os países que ratificaram a Convenção e é responsável por sua implementação. Cabe à COP, que se reúne anualmente, examinar os compromissos das Partes à luz dos objetivos da Convenção, bem como rever as Comunicações Nacionais, que são obrigações dos países descritas nos Artigos 4 e 12 da Convenção. Até o momento foram realizadas 12 COPs e 02 MOPs que serão discutidas adiante.

A Convenção estabeleceu ainda dois órgãos de assessoramento da COP, o Subsidiary Body for Technological and Scientific Advice (Órgão Subsidiário de Assessoramento Científico e Tecnológico) e o Subsidiary Body for Implementation (Órgão Subsidiário de Implementação). O primeiro é responsável por questões científicas, tecnológicas e metodológicas relacionadas à Convenção, servindo como "ponte" entre as informações científicas e a necessidade de direcionamento de políticas. O segundo é responsável pelo assessoramento e revisão da implementação da Convenção, análise das Comunicações Nacionais e dos Inventários de Emissão submetidos pelas Partes, além de fornecer conselho sobre os mecanismos financeiros e questões orçamentárias e administrativas.

\subsubsection{Os princípios da Convenção}

As fronteiras dos Estados muitas vezes não coincidem com a área geográfica dos impactos ambientais, como é o caso das mudanças climáticas. A localização geográfica das fontes de emissões de GEE, assim como a identificação dos países que vêm implementando políticas e medidas efetivas para redução destas emissões são importantes. Entretanto, mais importante ainda

do Ministério das Relações Exteriores da República Federativa do Brasil. Artigo 2. p. 6. http://www.mct.gov.br/index.php/content/view/4120.html. Acessado em 22/11/2005. 
são as questões ambientais que extrapolam estes aspectos, pois as conseqüências das mudanças climáticas serão globais.

Dessa forma, a Convenção de Mudanças Climáticas adota princípios que visam promover o objetivo da Convenção, dos quais destacamos o princípio da precaução, do poluidor-pagador e das responsabilidades comuns, porém diferenciadas.

O princípio da precaução, já discutido em nosso capítulo 1, está presente no Artigo 3.3 do texto da Convenção, conforme segue:

"As Partes devem adotar medidas de precaução para prever, evitar ou minimizar as causas da mudança do clima e mitigar seus efeitos negativos. Quando surgirem ameaças de danos sérios ou irreversíveis, a falta de plena certeza científica não deve ser usada como razão para postergar essas medidas, levando em conta que as políticas e medidas adotadas para enfrentar a mudança do clima devem ser eficazes em função dos custos, de modo a assegurar benefícios mundiais ao menor custo possível. Para esse fim, essas políticas e medidas devem levar em conta os diferentes contextos socioeconômicos, ser abrangentes, cobrir todas as fontes, sumidouros e reservatórios significativos de gases de efeito estufa e adaptações, e abranger todos os setores econômicos. As Partes interessadas podem realizar esforços, em cooperação, para enfrentar a mudança do clima." ${ }^{41}$

O texto da Convenção foi elaborado em um contexto no qual as pesquisas e estudos acerca das mudanças climáticas ainda apresentavam dúvidas e incertezas, mas justamente pela incerteza do porvir é que se faz necessária a adoção de tal princípio, vislumbrando/garantindo a mitigação de efeitos negativos. Com a publicação do $4^{\circ}$ relatório do IPCC, no qual se tem evidências indiscutíveis sobre a ação antrópica no aquecimento do planeta, a utilização do princípio da precaução foi essencial para evitar conseqüências ainda mais desastrosas.

\footnotetext{
${ }^{41}$ BRASIL. Ministério da ciência e tecnologia. Texto da Convenção-Quadro das Nações Unidas sobre Mudança do Clima. Editado e traduzido pelo Ministério da Ciência e Tecnologia com o apoio do Ministério das Relações Exteriores da República Federativa do Brasil. Artigo 3.3. p. 7. http://www.mct.gov.br/index.php/content/view/4120.html. Acessado em 22/11/2005.
} 
Os princípios das responsabilidades comuns porém diferenciadas e do poluidor-pagador estão presentes no Artigo 3.1 da Convenção:

"As Partes devem proteger o sistema climático em benefício das gerações presentes e futuras da humanidade com base na eqüidade e em conformidade com suas responsabilidades comuns mas diferenciadas e respectivas capacidades. Em decorrência, as Partes países desenvolvidos devem tomar a iniciativa no combate à mudança do clima e seus efeitos.." ${ }^{22}$

Os países desenvolvidos, pioneiros nos processos de industrialização e também nas mudanças de uso do solo - foram (e ainda são) os responsáveis pela maior parte das emissões antrópicas de CO2, conforme reconhece, coerentemente, a Convenção:

"Observando que a maior parcela das emissões globais, históricas e atuais, de gases de efeito estufa é originária dos países desenvolvidos, que as emissões per capita dos países em desenvolvimento ainda são relativamente baixas e que a parcela de emissões globais originárias dos países em desenvolvimento crescerá para que eles possam satisfazer suas necessidades sociais e de desenvolvimento." 43

Ao aplicar o princípio da responsabilidade comum porém diferenciada, a Convenção dividiu os países em dois grupos principais, o primeiro composto pelos países listados em seu Anexo I, e o segundo composto por países não listados em tal Anexo.

O Anexo I da Convenção é composto pelos países pertencentes em 1992 à Organização para a Cooperação e Desenvolvimento Econômico (OCDE), à União Européia e também pelas antigas repúblicas socialistas da União Soviética, que passam por processo de transição para economias de mercado.

${ }^{42}$ BRASIL. Ministério da ciência e tecnologia. Texto da Convenção-Quadro das Nações Unidas sobre Mudança do Clima. Editado e traduzido pelo Ministério da Ciência e Tecnologia com o apoio do Ministério das Relações Exteriores da República Federativa do Brasil. Artigo 2. p. 6. http://www.mct.gov.br/index.php/content/view/4120.html. Acessado em 22/11/2005.

${ }^{43}$ BRASIL. Ministério da ciência e tecnologia. Texto da Convenção-Quadro das Nações Unidas sobre Mudança do Clima. Editado e traduzido pelo Ministério da Ciência e Tecnologia com o apoio 
Tabela 3: Países do Anexo I

\begin{tabular}{|l|l|}
\hline Alemanha & Islândia \\
\hline Austrália & Itália \\
\hline Áustria & Japão \\
\hline Bélgica & Letônia* \\
\hline Bielo-Rússia* & Liechtenstein $^{*}$ \\
\hline Bulgária* & Lituânia* \\
\hline Canadá & Luxemburgo \\
\hline Comunidade Econômica Européia & Mônaco \\
\hline Croácia* & Noruega \\
\hline Dinamarca & Nova Zelândia \\
\hline Eslováquia* & Países Baixos \\
\hline Eslovênia* & Polônia* \\
\hline Espanha & Portugal \\
\hline Estados Unidos & Reino Unido da Grã-Bretanha e Irlanda do Norte \\
\hline Estônia* & República Tcheca* \\
\hline Federação Russa* & Romênia* \\
\hline Finlândia & Suécia \\
\hline França & Suíça \\
\hline Grécia & Turquia \\
\hline Hungria* & Ucrânia* \\
\hline Irlanda & \\
\hline
\end{tabular}

Fonte: BRASIL. Ministério da ciência e tecnologia. Texto da Convenção-Quadro das Nações Unidas sobre Mudança do Clima. Editado e traduzido pelo Ministério da Ciência e Tecnologia com o apoio do Ministério das Relações Exteriores da República Federativa do Brasil. Anexo I. http://www.mct.gov.br/index.php/content/view/4120.html. Acessado em 22/11/2005.

* Países em processo de transição para uma economia de mercado e que passaram a fazer parte do Anexo I mediante emenda que entrou em vigor no dia 13 de agosto de 1998, em conformidade com a decisão 4/CP.3 adotada na COP3.

Ao diferenciar por países as responsabilidades comuns, a Convenção estabeleceu medidas também diferenciadas. Dessa forma, fez ainda uma segunda classificação, levando em consideração além da responsabilidade do país pelo problema, sua capacidade para prover assistência financeira aos países em desenvolvimento. Portanto, são os Estados mais desenvolvidos, que têm essa capacidade e foram classificados como Anexo II, que é um subconjunto do Anexo I. Os países do Anexo II possuem a obrigação de fornecer recursos tecnológicos e financeiros para ajudar países em desenvolvimento a promoverem medidas de mitigação, a se adaptarem aos impactos da mudança climática e a avaliarem suas vulnerabilidades específicas.

do Ministério das Relações Exteriores da República Federativa do Brasil. Artigo 2. p. 3. http://www.mct.gov.br/index.php/content/view/4120.html. Acessado em 22/11/2005. 
Tabela 4: Países do Anexo II

\begin{tabular}{|l|l|}
\hline Alemanha & Islândia \\
\hline Austrália & Itália \\
\hline Áustria & Japão \\
\hline Bélgica & Luxemburgo \\
\hline Canadá & Noruega \\
\hline Comunidade Econômica Européia & Nova Zelândia \\
\hline Dinamarca & Países Baixos \\
\hline Espanha & Portugal \\
\hline Estados Unidos & Reino Unido da Grã-Bretanha e Irlanda do Norte \\
\hline Finlândia & Suécia \\
\hline França & Suíça \\
\hline Grécia & Turquia \\
\hline Irlanda & \\
\hline
\end{tabular}

Fonte: BRASIL. Ministério da ciência e tecnologia. Texto da Convenção-Quadro das Nações Unidas sobre Mudança do Clima. Editado e traduzido pelo Ministério da Ciência e Tecnologia com o apoio do Ministério das Relações Exteriores da República Federativa do Brasil. Anexo II. http://www.mct.gov.br/index.php/content/view/4120.html. Acessado em 22/11/2005.

A diferenciação feita aos países está explícita no Artigo 4 da Convenção, no qual estão as obrigações das Partes. Em seu parágrafo $1^{\circ}$, destacamos algumas obrigações por reforçarem o princípios das responsabilidades comuns porém diferenciadas e por enunciarem mecanismos que serão discutidos adiante :

"1. Todas as Partes, levando em conta suas responsabilidades comuns mas diferenciadas e suas prioridades de desenvolvimento, objetivos e circunstâncias específicos, nacionais e regionais, devem:

Elaborar, atualizar periodicamente, publicar e por à disposição da Conferência das Partes, em conformidade com o Artigo 12, inventários nacionais de emissões antrópicas por fontes e das remoções antrópicas por sumidouros de todos os gases de efeito estufa não controlados pelo Protocolo de Montreal, empregando metodologias comparáveis a serem acordadas pela Conferência das Partes;

(..)

Promover e cooperar para o desenvolvimento, aplicação e difusão, inclusive transferência, de tecnologias, práticas e processos que controlem, reduzam ou previnam as emissões antrópicas de gases de efeito estufa não controlados pelo 
Protocolo de Montreal em todos os setores pertinentes, inclusive nos setores de energia, transporte, indústria, agricultura, silvicultura e administração de resíduos;

Promover a gestão sustentável, bem como promover e cooperar na conservação e fortalecimento, conforme o caso, de sumidouros e reservatórios de todos os gases de efeito estufa não controlados pelo Protocolo de Montreal, incluindo a biomassa, as florestas e os oceanos como também outros ecossistemas terrestres, costeiros e marinhos;

(..)

(...)

$(\ldots)$

$(\ldots)$

(...)

$(\ldots)^{n 44}$

No parágrafo $2^{\circ}$, também destacamos algumas obrigações que são exclusivas dos países desenvolvidos e das demais partes listadas no Anexo I, e de suma importância para o entendimento da implementação da Convenção:

"2. As Partes países desenvolvidos e demais Partes constantes do Anexo I se comprometem especificamente com o seguinte:

a) Cada uma dessas Partes deve adotar políticas nacionais 1/e medidas correspondentes para mitigar a mudança do clima, limitando sua emissões antrópicas de gases de efeito estufa e protegendo e aumentando seus sumidouros e reservatórios de gases de efeito estufa. Essas políticas e medidas demonstrarão que os países desenvolvidos estão tomando a iniciativa no que se refere a modificar as tendências de mais longo prazo das emissões antrópicas em conformidade com o objetivo desta

\footnotetext{
${ }^{44}$ BRASIL. Ministério da ciência e tecnologia. Texto da Convenção-Quadro das Nações Unidas sobre Mudança do Clima. Editado e traduzido pelo Ministério da Ciência e Tecnologia com o apoio do Ministério das Relações Exteriores da República Federativa do Brasil. Artigo 3.3. p. 7 - 9. http://www.mct.gov.br/index.php/content/view/4120.html. Acessado em 22/11/2005
} 
Convenção, reconhecendo que contribuiria para tal modificação a volta, até o final da presente década, a níveis anteriores das emissões antrópicas de dióxido de carbono e de outros gases de efeito estufa não controlados pelo Protocolo de Montreal; e levando em conta as diferentes situações iniciais e enfoques, estruturas econômicas e fontes de recursos dessas Partes, a necessidade de manter um crescimento econômico vigoroso e sustentável, as tecnologias disponíveis e outras circunstâncias individuais, bem como a necessidade de que cada uma dessas Partes contribua eqüitativa e adequadamente ao esforço mundial voltado para esse objetivo. Essas Partes podem implementar tais políticas e medidas juntamente com outras Partes e podem auxiliar essas outras Partes a contribuírem para que se alcance o objetivo desta Convenção e, particularmente, desta alínea;

$\begin{array}{ll}\text { b) } & (\ldots) \\ \text { c) } & (\ldots) \\ \text { d) } & (\ldots) \\ \text { e) } & (\ldots) \\ \text { f) } & (\ldots) \\ \text { g) } & (\ldots)^{45}\end{array}$

Os parágrafos 3, 4 e 5 do Artigo 4, tratam entre outros aspectos, da transferência de recursos tecnológicos e financeiros para países em desenvolvimento, necessários para que estes possam arcar com os custos de mitigação e adequação aos efeitos adversos da mudança do clima, suscitando, portanto, as bases para a implementação do princípio do poluidor-pagador traduzido nos mecanismos financeiros de atendimento ao objetivo da Convenção:

"3. As Partes países desenvolvidos e demais Partes desenvolvidas incluídas no Anexo II devem prover recursos financeiros novos e adicionais para cobrir integralmente os custos por elas concordados incorridos por Partes países em desenvolvimento no cumprimento de suas obrigações previstas no Artigo 12, parágrafo 1. Também devem prover os recursos financeiros, inclusive para fins de transferência de tecnologias, de que necessitam as Partes países em desenvolvimento para cobrir

\footnotetext{
${ }^{45}$ BRASIL. Ministério da ciência e tecnologia. Texto da Convenção-Quadro das Nações Unidas sobre Mudança do Clima. Editado e traduzido pelo Ministério da Ciência e Tecnologia com o apoio do Ministério das Relações Exteriores da República Federativa do Brasil. Artigo 4. p. 9-10. http://www.mct.gov.br/index.php/content/view/4120.html. Acessado em 22/11/2005.
} 
integralmente os custos adicionais por elas concordados decorrentes da implementação de medidas previstas no parágrafo 1 deste Artigo e que sejam concordados entre uma Parte país em desenvolvimento e a entidade ou entidades internacionais a que se refere o Artigo 11, em conformidade com esse Artigo. Para o cumprimento desses compromissos deve ser levada em conta a necessidade de que o fluxo de recursos seja adequado e previsível e a importância de distribuir os custos entre as Partes países desenvolvidos.

4. As Partes países desenvolvidos e demais Partes desenvolvidas incluídas no Anexo II devem também auxiliar as Partes países em desenvolvimento, particularmente vulneráveis aos efeitos negativos da mudança do clima, a cobrirem os custos de sua adaptação a esses efeitos negativos.

5. As Partes países desenvolvidos e outras Partes desenvolvidas incluídas no Anexo II devem adotar todas as medidas possíveis para promover, facilitar e financiar, conforme o caso, a transferência de tecnologias e de conhecimentos técnicos ambientalmente saudáveis, ou o acesso aos mesmos, a outras Partes, particularmente às Partes países em desenvolvimento, a fim de capacitá-las a implementar as disposições desta Convenção. Nesse processo, as Partes países desenvolvidos devem apoiar o desenvolvimento e a melhoria das capacidades e tecnologias endógenas das Partes países em desenvolvimento. Outras Partes e organizações que estejam em condições de fazê-lo podem também auxiliar a facilitar a transferência dessas tecnologias." ${ }^{46}$

O estabelecimento da Convenção foi a primeira etapa do processo de negociação sobre as mudanças climáticas. Os desdobramentos das ações necessárias para assegurar o cumprimento dos objetivos e princípios estabelecidos pela Convenção serão discutidos a seguir.

\footnotetext{
${ }^{46}$ BRASIL. Ministério da ciência e tecnologia. Texto da Convenção-Quadro das Nações Unidas sobre Mudança do Clima. Editado e traduzido pelo Ministério da Ciência e Tecnologia com o apoio do Ministério das Relações Exteriores da República Federativa do Brasil. Artigo 4. p. 10-11. http://www.mct.gov.br/index.php/content/view/4120.html. Acessado em 22/11/2005.
} 


\subsection{As Conferências das Partes ${ }^{47}$}

\subsubsection{Conferência das Partes 1}

A primeira Conferência das Partes ocorreu entre os dias 28 de março e 07 de abril de 1995 em Berlim, na Alemanha, contando com representantes de 117 países. A Conferência das Partes em sua primeira sessão fez uma revisão do Artigo 4, parágrafo 2 (a) e (b) - que dizem respeito a elaboração, atualização e publicação de inventários nacionais de emissões, e a formulação, implementação, publicação e atualização de programas de mitigação à mudança do clima - e concluiu que as alíneas não estavam adequadas, tendo em vista que o compromisso dos países desenvolvidos em reduzir suas emissões para os níveis de 1990, até o ano de 2000, não seria suficiente para se atingir os objetivos de longo prazo da Convenção, dado que as emissões vinham crescendo, descumprindo desta forma o compromisso.

O Mandato de Berlim, como ficou conhecida a Decisão 1/CP.1, estabeleceu o início de um processo que possibilitava proposição de ações adequadas para o período além de 2000, incluindo o fortalecimento dos compromissos das Partes incluídas no Anexo I por meio da adoção de um protocolo ou outro instrumento legal. O Mandato estabeleceu ainda que não deveria ser introduzido qualquer novo compromisso para as Partes não incluídas no Anexo I, e reafirmava os compromissos das responsabilidades comuns mas diferenciadas existentes no Artigo 4.1 da Convenção.

Foi decidida ainda a adoção de uma fase piloto de atividades implementadas conjuntamente entre as Partes do Anexo I, como um meio subsidiário para o cumprimento dos objetivos de redução de emissões.

Em resposta ao Mandato de Berlim e com objetivo do fortalecimento do compromisso dos países desenvolvidos em reduzir suas emissões, foi então criado o grupo Ad Hoc sobre o Mandato de Berlim (AGBM), que iniciou o esboço de um protocolo que deveria estar pronto para aprovação até a Terceira Conferência das Partes.

\footnotetext{
${ }^{47}$ As informações sobre as Conferências das Partes foram baseadas nos documentos oficiais publicados no site da Convenção.
} 


\subsubsection{Conferência das Partes 2}

A segunda Conferência das Partes ocorreu em Genebra, na Suíça, entre os dias 08 e 19 de julho de 1996. A COP 2 estabeleceu a possibilidade dos Países Não Anexo I enviarem suas comunicações iniciais, especificando suas prioridades de desenvolvimento nacionais e regionais, seus objetivos e suas circunstâncias que serviriam de base para enfrentar a mudança do clima e seus efeitos adversos. A partir dessas informações as Partes Não Anexo I poderiam solicitar auxílio financeiro e tecnológico do Fundo Global para o Meio ambiente (GEF - mecanismo financeiro interino da Convenção).

Foi assinada ainda a Declaração de Genebra, que estabelecia um acordo para a criação de obrigações legais com o objetivo de reduzir as emissões de dióxido de carbono.

\subsubsection{Conferência das Partes 3}

Em 1997, a terceira Conferência das Partes, realizada em Kyoto , no Japão, de $1^{\circ}$ a 11 de dezembro reuniu representantes de 159 nações. Inúmeros acontecimentos políticos colocaram em risco a elaboração/sucesso do protocolo ocorreram nos dois anos de negociações. Destacamos a adoção por unanimidade do Senado Americano da Resolução Byrd-Hagel,

"Segundo esta Resolução, os EUA não poderiam assinar nenhum protocolo à CQNUMC (ou quaisquer outros acordos), que: i) estabelecessem novos compromissos de redução ou limitação da emissão de GEE, a não ser que o protocolo (ou os outros acordos quaisquer) estabelecessem para o mesmo período, estes novos compromissos de redução ou limitação da emissão de GEE também para os países em desenvolvimento e ii) resultassem em danos econômicos aos EUA." ${ }^{48}$

Essa atitude do Senado americano deixa clara a aplicação do conceito de realismo político, na qual o estabelecimento de uma resolução visa a proteger os interesses soberanos do Estado. Entretanto, essa atitude não exime a

\footnotetext{
${ }^{48}$ PEREIRA, André Santos. Do fundo ao mecanismo: gênese, características e perspectivas para o mecanismo de desenvolvimento limpo; ao encontro ou de encontro à equidade? Rio de Janeiro, 2002. Pág. 53.
} 
responsabilidade comum porém diferenciada dos Estados Unidos diante das emissões de GEE.

Após dois anos de intensas negociações e oito sessões do Grupo Ad Hoc sobre o Mandato de Berlim para a elaboração do texto do protocolo, a Conferência das Partes:

"1. Decide adotar o Protocolo de Kyoto à Convenção-Quadro das Nações Unidas sobre Mudança do Clima;

2. Solicita que o Secretário Geral das Nações Unidas seja o Depositário desse Protocolo abrindo-o para assinatura em Nova York de 16 de março de 1998 a 15 de março de 1999;

3. Convida todas as Partes da Convenção-Quadro das Nações Unidas sobre Mudanças do Clima a assinar o Protocolo no dia 16 de março de 1998 ou na primeira subseqüentemente e depositar instrumentos de ratificação, aceitação ou aprovação, ou instrumentos de adesão conforme o caso, o mais rápido possível;

4. Convida ainda os Estados que não são Partes da Convenção a ratificar ou a ela aderir, conforme o caso, sem demora, a fim de que possam tornar-se Partes do Protocolo;" 49

O Protocolo de Kyoto é composto de 28 artigos e 2 anexos e sua publicação inclui 3 decisões adotadas pela COP 3 e uma tabela, que fornecem informações importantes para sua adoção e implementação, baseando-se nos princípios, objetivos e estrutura institucional da Convenção. Abordaremos o Protocolo de Kyoto em detalhes mais adiante.

A COP 3 estabeleceu ainda algumas outras decisões importantes, tais como a implementação do Artigo 4, parágrafos 8 e 9 da Convenção, que solicitava ao Órgão Subsidiário de Implementação o início do processo de identificação e determinação de ações para suprir as necessidades específicas das Partes países em desenvolvimento, resultantes de efeitos adversos da mudança do clima, considerando ações relacionadas com financiamento, seguro e transferência de tecnologia. A Decisão 4/CP.3 fez uma emenda à lista do Anexo I da Convenção, excluindo o nome da Tchecoslováquia e incluindo a Croácia, 
República Tcheca, Liechtenstein, Mônaco, Eslováquia e Eslovênia na lista dos países do Anexo I.

\subsubsection{Conferência das Partes 4}

A quarta Conferência das Partes ocorreu entre os dias 2 e 13 de novembro de 1998 em Buenos Aires, Argentina. Determinada a fortalecer a implementação da Convenção-Quadro das Nações Unidas sobre Mudanças do Clima e preparar-se para a entrada em vigor do Protocolo de Kyoto, a Conferência das Partes adotou o Plano de Ação de Buenos Aires, que indicava as diretrizes para as seguintes decisões:

- Modalidades e procedimentos para um mecanismo de desenvolvimento limpo com o objetivo de assegurar transparência, eficiência e prestação de contas por meio de auditorias e verificações independentes das atividades de projeto;

- Desenvolvimento e transferência de tecnologias;

- Implementação do Artigo 4.8 e 4.9 da Convenção, relacionados às obrigações dos países signatários, no fornecimento de auxílio financeiro e transferência de tecnologias aos países em desenvolvimento e/ou mais susceptíveis aos impactos das mudanças climáticas;

- Atividades implementadas conjuntamente em fase piloto;

- Programa de trabalho sobre mecanismos do Protocolo de Kyoto;

- Preparação para a primeira sessão da Conferência das Partes na qualidade de reunião das Partes do Protocolo de Kyoto.

${ }^{49}$ BRASIL. Ministério da Ciência e Tecnologia. Decisão 1/CP.3 - Adoção do Protocolo de Quioto à Convenção-Quadro das Nações Unidas sobre Mudança do Clima. In:

http://www.mct.gov.br/index.php/content/view/18789.html?, acessado em 02/05/2007. 


\subsubsection{Conferência das Partes 5}

Na quinta Conferência das Partes, realizada em Bonn, na Alemanha, entre os dias 25 de outubro e 05 de novembro de 1999, foram decididas questões relativas à implementação do Plano de Ação de Buenos Aires, sendo que as Partes deveriam intensificar os trabalhos preparatórios necessários para que pudessem tomar decisões na COP 6. A intensificação dos trabalhos tinha como objetivo a entrada em vigor do Protocolo de Kyoto o mais breve possível.

Por meio da decisão 10/CP.5, a Conferência das Partes reconheceu que os países em desenvolvimento, devido a sua maior vulnerabilidade aos efeitos adversos da mudança do clima, requerem iniciativas especiais de capacitação, ficando decidido que o apoio financeiro e técnico para atividades de capacitação deve ser oferecido por meio do mecanismo financeiro e de agências bilaterais e multilaterais, conforme o caso.

A COP 5 decidiu ainda adotar um programa de trabalho e elementos para tomada de decisões sobre as questões de uso da terra, mudança no uso da terra e florestas (Land Use, Land Use Change and Forestation - LULUCF - Uso da Terra, Mudança no Uso da Terra e Florestamento) adotadas pelo Órgão Subsidiário de Assessoramento Científico e Tecnológico, para que a Conferência das Partes, em sua sexta sessão, recomende esboços de decisões.

\subsubsection{Conferência das Partes 6}

A sexta Conferência das Partes ocorreu em Haia, Países Baixos, de 13 a 24 de novembro de 2000. A conclusão do Plano de Ação de Buenos Aires estava prevista para a COP 6, segundo a própria decisão que o estabeleceu e, por este motivo, houve uma grande expectativa em torno da realização desta Conferência. Apesar do estabelecimento de um plano de ação e de um prazo limite ser uma condição necessária, não era por si só uma condição suficiente para que as Partes chegassem a um acordo (em torno de vários tópicos referentes aos mecanismos e aos outros itens da agenda) tendo em vista os inúmeros interesses envolvidos. O impasse no processo de negociação 
impossibilitou a conclusão do Plano de Ação de Buenos Aires até o dia 24 de novembro de 2000 (data prevista inicialmente para o término da COP 6).

Dentre os motivos do impasse destacam-se o antagonismo e rigidez das posições de Estados Unidos e da União Européia (UE), influenciadas respectivamente, dentre outros motivos, pela indefinição política dos Estados Unidos, que não sabiam quem seria o novo presidente, e pela falta de coordenação política entre os membros da UE.

As negociações na COP 6 estavam diretamente ligadas aos interesses individuais dos grupos políticos, que não aceitavam fazer concessões, impossibilitando o progresso dos trabalhos. Já que as discussões não haviam progredido, o presidente da sessão, Jan Pronk, suspendeu os trabalhos sem os ter concluído. Com esta ação, a conclusão dos trabalhos foi transferida para maio/junho de 2001.

A nota emitida pelo presidente Jan Pronk endereçava as principais questões que continuavam sem solução nos documentos transmitidos pelo Órgão Subsidiário de Implementação: transferência de tecnologia, implementação dos Artigos 4.8 e 4.9 e 3.14 do Protocolo e questões financeiras; uso do solo, mudança do uso do solo e florestas (LULUCF); mecanismos; e políticas, medidas, conformidade, contabilidade, prestação de contas e auditoria.

\subsubsection{Conferência das Partes 6 Bis}

$\mathrm{Na}$ Conferência das Partes número 6, realizada em Haia na Holanda, não foi possível estabelecer regras operacionais para o Protocolo, devido a divergência entre os Estados Unidos e os países europeus. Em função do impasse criado a conferência foi suspensa.

A Conferência, que retomaria as discussões da COP6, estava marcada para o mês de maio de 2001, porém uma série de acontecimentos políticos envolvendo, sobretudo, os Estados Unidos, fizeram com que a reunião fosse transferida para julho. A vitória de George W. Bush para a presidência deu novos rumos para as negociações. Usando como justificativa a crise de energia (preços elevados e escassez do produto) pela qual passava os Estados Unidos, Bush informava que o programa de redução de emissões de CO2 deveria ser 
reavaliado, pois não poderia colocar em risco a economia americana, decidindo não continuar nas discussões da Convenção.

Devido ao peso político e econômico dos Estados Unidos, e sua grande responsabilidade pelo aquecimento global, a não participação nas negociações poderia resultar no fracasso do Protocolo de Kyoto, caso conseguissem o apoio do Japão e da Rússia.

A retomada das discussões em Bonn, Alemanha, entre os dias 16 e 27 de julho de 2001, foi fundamental para garantir a sobrevivência e os novos rumos do Protocolo. Esta Conferência ficou conhecida como a COP 6 BIS e o seu produto mais importante foi o Acordo de Bonn, um acordo político que garantiu a sobrevivência do Protocolo, por meio de concessões feitas para garantir a permanência de países como o Japão e a Federação Russa e ao mesmo tempo respeitando os interesses da União Européia e dos países subdesenvolvidos.

Destacamos, do Acordo de Bonn, algumas decisões relativas ao mecanismo de desenvolvimento limpo, o qual trataremos mais adiante :

- $\quad$ "Eqüidade: reconhece-se que o Protocolo de Quioto não criou ou delegou nenhum direito ou título de nenhuma espécie aos países desenvolvidos e, ainda, que estes países devem implementar ações domésticas, de acordo com as circunstâncias nacionais e com vistas a reduzir emissões de tal modo a estreitar as diferenças per capita entre países desenvolvidos e em desenvolvimento, à medida que avançam para atingir o objetivo último da convenção.

- Suplementaridade: o uso dos mecanismos deve ser suplementar à ação doméstica e deve, portanto, constituir um elemento significativo do esforço feito por cada país desenvolvido para atingir seu compromisso de redução e/ou limitação de emissões de gases de efeito estufa.

- Energia nuclear: os países desenvolvidos devem abster-se de usar certificados de reduções de emissão do MDL gerados por instalações nucleares, para atingir seus compromissos no artigo 3.1.

- Composição do Conselho-Executivo do MDL: aceitou-se a fórmula proposta pelo ministro Pronk, segundo a qual o comitê seria composto por um membro de cada um dos cinco grupos regionais das 
Nações Unidas e um representante dos pequenos Estados insulares, e por dois membros escolhidos entre os países do Anexo 1 e outros dois representando países não-incluídos no Anexo 1, totalizando dez membros.

- $\quad$ Nível de reserva do período de compromisso: cada país desenvolvido deve manter, em seu registro nacional, uma reserva de período de compromisso, que não deve cair abaixo de $90 \%$ da quantidade atribuída para a Parte, calculada de acordo com o artigo 3, parágrafos 7 e 8, do Protocolo de Quioto ou $100 \%$ de cinco vezes seu mais recente inventário revisado, o que for menor. Isto funcionará como uma espécie de reserva bancária, diminuindo o risco de um excesso de vendas a descoberto no comércio de emissões.

- $\quad$ Percentual para adaptação: o percentual para contribuir com os países em desenvolvimento que são particularmente vulneráveis aos efeitos adversos da mudança do clima, permitindo cobrir seus custos com projetos de adaptação, deve ser de $2 \%$ dos certificados de reduções de emissão emitidos para a atividade de projeto do MDL.

- Acordo de cumprimento como critério de elegibilidade para participar dos mecanismos: a elegibilidade para um país desenvolvido participar dos mecanismos deve depender de seu cumprimento com os requisitos metodológicos e de produção de relatórios dos artigos 5.1, 5.2, 7.1 e 7.4 do Protocolo de Quioto, com a supervisão realizada pelo ramo coercitivo do Comitê de Cumprimento de acordo com as provisões relevantes. Somente países que aceitaram o acordo suplementar de cumprimento ao Protocolo de Quioto devem estar autorizados a transferir ou adquirir créditos gerados pelo uso de mecanismos.

- $\quad$ Sumidouros no MDL: decidiu-se que apenas projetos de reflorestamento e de estabelecimento de novas florestas serão elegíveis no MDL, durante o primeiro período de compromisso. A implementação de tais projetos deve ser guiada pelos princípios referidos na seção de uso da terra, mudança do uso da terra e florestas. As definições e as modalidades devem ser desenvolvidas pelo SBSTA para decisão na COP-8. Estas modalidades, a serem discutidas, devem incluir não-permanência, adicionalidade, vazamentos, escala, incertezas e impactos ambientais e socioeconômicos (inclusive impactos na biodiversidade e ecossistemas naturais). 
- Adicionalidade financeira: fundos públicos de países desenvolvidos para projetos de MDL não devem resultar em redução da assistência oficial para desenvolvimento e devem ser separados e não contabilizados nas obrigações financeiras desses países.

- Definição dos projetos de pequena escala: foram definidos três tipos de projetos de pequena escala, a saber: 1) projetos de energia renováveis menores que $15 \mathrm{MW}$; 2) projetos de aumento de eficiência energética menores que $15 \mathrm{GWh} / a n o$; e 3) outros projetos que reduzam emissões e que diretamente emitam menos de 15 mil toneladas de gás carbônico equivalente por ano. Além disso, determinou-se que o Conselho Executivo deve desenvolver e recomendar à COP-8 modalidades e procedimentos simplificados para estes projetos e rever e fazer recomendações sobre os outros tipos de projetos (item 3 acima) à primeira reunião das Partes do Protocolo, quando este entrar em vigor.

- Transferência de CERs (Certificados de Redução de Emissões): esta questão não foi resolvida, mas a posição apresentada pelo G-77 e a China nas discussões, que separava o debate sobre transações com os certificados da discussão sobre utilização dos certificados, foi claramente redigida e reafirmada no texto da decisão ministerial." ${ }^{50}$

Apesar dos acordos firmados na COP 6, não houve tempo hábil para a conclusão do Plano de Ação de Buenos Aires, sendo adiada para a Conferência das Partes 7.

\subsubsection{Conferência das Partes 7}

A sétima Conferência das Partes ocorreu em Marrakesh, no Marrocos de 29 de outubro a 10 de novembro de 2001, reunindo 172 países. A principal meta era completar as tarefas inacabadas das COPs 6 e 6 Bis, encerrando o período de três anos de negociações do Plano de Ação de Buenos Aires. O acordo de Bonn serviu como base para as negociações.

\footnotetext{
${ }^{50}$ MIGUEZ, José Domingos Gonzales. A Mudança Global do Clima: Perspectivas pós Bonn. In: http://www.mct.gov.br/index.php/content/view/21403.html - consultado em 11/05/2007.
} 
Após duas semanas de negociações foi fechado um pacote de regras que manteve a integridade do Acordo de Bonn e do Protocolo de Kyoto. Para se chegar a esse resultado foi necessário que a União Européia e o Grupo G77/China cedessem espaço aos países do "Umbrella Group" (grupo formado por Japão, Austrália, Canadá e Rússia). O objetivo do "Umbrella Group" era conseguir um acordo não obrigatório, que houvesse poucos critérios de elegibilidade para a utilização dos mecanismos de flexibilização (o que prejudicaria os países em desenvolvimento, pois são os maiores beneficiados dos mecanismos), que houvesse pouca participação pública e transparência, e que não houvesse necessidade de fornecer informações detalhadas sobre os sumidouros.

O Acordo de Marrakesh, entre vários pontos, definiu as regras operacionais para LULUCF, para os mecanismos de flexibilização e para os Artigos 5, 7 e 8 que tratam, respectivamente, da definição do sistema nacional para o inventário de emissões, das informações adicionais à Convenção derivadas do Protocolo e do processo de revisão das comunicações nacionais. No Acordo foram estabelecidas ainda regras que limitarão a utilização de créditos oriundos de florestas e agricultura; projetos unilaterais de MDL (ou seja, sem a participação de países do Anexo I) serão permitidos; criação do Comitê Executivo do MDL, autorizado a aprovar metodologias de linhas de bases, planos de monitoramento e limites para projetos, a creditar entidades operacionais e desenvolver e manter registros dos projetos de MDL.

O Acordo de Marrakesh determinou conseqüências legais para o não cumprimento das reduções, incluindo a impossibilidade de participar dos mecanismos financeiros.

\subsubsection{Conferência das Partes 8}

A Conferência das Partes 8 ocorreu em Nova Delhi, na Índia, entre os dias 23 de outubro e $1^{\circ}$ de novembro de 2002, reunindo mais de 4.300 participantes de 167 países. A divisão entre as posições dos países desenvolvidos e dos países em desenvolvimento foi evidente na COP 8. Muitos países esperavam que a dicotomia entre países anexo I e não anexo I fosse 
amenizada, expondo os interesses das várias partes não Anexo I, facilitando a adoção de compromissos mais abrangentes, o que não ocorreu.

Havia certa expectativa quanto à definição das modalidades e procedimentos para as atividades de reflorestamento (Processo de aumento da capacidade de seqüestro de carbono pelo plantio de florestas em áreas que foram devastadas) e florestamento (estabelecimento de florestas em áreas anteriormente não ocupadas por esse tipo de atividades), no âmbito do Mecanismo de Desenvolvimento Limpo (MDL), o que não se concretizou.

Embora não tenha alcançado o sucesso desejado, a COP estabeleceu a Declaração de Delhi, na qual reafirmou o desenvolvimento e a erradicação de pobreza como prioridades nos países em desenvolvimento, bem como a diferenciação das responsabilidades e prioridades de desenvolvimento nacionais e circunstâncias na implementação dos compromissos da UNFCCC. Outro fato importante foi o acordo das Partes em relação às regras e aos procedimentos do MDL, concluindo as diretrizes da revisão dos artigos 5,7 e 8 do Protocolo de Kyoto e proporcionando orientação adicional para o Fundo LDC - Least Developed Countries (recurso financeiro para as Partes não incluídas no Anexo I).

Embora a Declaração de Delhi não tenha iniciado um diálogo formal sobre a ampliação dos compromissos futuros, informalmente as discussões começaram.

\subsubsection{Conferência das Partes 9}

A nona Conferência das Partes aconteceu entre os dias $1^{\circ}$ e 12 de dezembro de 2003 em Milão, Itália, e reuniu mais de 5.000 participantes de 166 países. As Partes adotaram várias decisões e conclusões acerca de inúmeras questões, incluindo: guia de boas práticas nas questões de LULUCF; o Special Climate Change Fund (SCCF); e o Least Developed Countries Fund (LDC).

Apesar de todas as decisões colocadas acima, o ponto forte da COP 9 foi a discussão de regras e procedimentos para a inclusão de atividades florestais no MDL.

Nesse sentido, o grande avanço realizado foi o fechamento de um "pacote de regras" que define a maneira como os projetos de florestamento e 
reflorestamento (no Protocolo, a modalidade de conservação de florestas está fora) deverão ser conduzidos para reconhecimento junto à Convenção do Clima e obtenção de créditos de carbono, no escopo do MDL.

Das principais questões que estavam em discussão anteriormente, foram fechadas e as seguintes definições que merecem destaque:

- Limite do projeto: As áreas de reflorestamento de um Projeto Florestal poderão ser descontínuas (desconexas), ou seja, um mesmo projeto poderá ter reflorestamentos em duas áreas distantes;

- Questão da permanência das Certified Emission Reductions (CERs): Nesta questão foi acertada a adoção de CERs temporárias (tCERs ) e CERs de longo prazo (ICERs):

- CERs temporárias: As CERs temporárias são válidas apenas durante o período de comprometimento em que foram emitidas. Por exemplo, as CERs geradas em um projeto de reflorestamento/florestamento que está em andamento (gerando CERs), serão válidas apenas para o primeiro período de comprometimento (2008 a 2012), após 2012, deixam de valer como CERs.

- CERs de longo prazo: Os créditos de longo prazo de um projeto de reflorestamento expiram apenas ao final do período de creditação, sob o qual foi submetido o projeto de MDL.

- Projetos Florestais de Pequena Escala (Small-scale afforestation and reforestation project activities): São aqueles projetos desenvolvidos por pequenas comunidades (que geralmente apresentam certa dificuldade e condições particulares de participação no MDL), definidas pelo país no qual o projeto está instalado, não podendo ultrapassar a remoção de 8 quilo-toneladas de $\mathrm{CO} 2$ por ano. Caso o Projeto de Pequena Escala ultrapasse essa quantidade de 8 quilotoneladas de $\mathrm{CO} 2$ por ano, o excesso não será elegível à aquisição de CERs. 


\subsubsection{Conferência das Partes 10}

Após um longo período de indefinições, o presidente russo Vladimir Puttin formalizou a ratificação da Rússia ao Protocolo de Kyoto no dia 04 de novembro de 2004. Tal medida permitiu a entrada em vigor do Protocolo, que passou a vigorar no prazo de 90 dias após o recebimento dos documentos pelo Secretário Geral das Nações Unidas em Nova York.

Dessa forma, a décima Conferência das Partes, que ocorreu de 6 a 17 de dezembro de 2004, reuniu mais de 6.100 participantes de 167 países em Buenos Aires, na Argentina, ocorreu sob os auspício da entrada em vigor do Protocolo de Kyoto.

Durante a Conferência, as Partes endereçaram e adotaram decisões sobre várias questões, destacando-se: transferência de tecnologia, questões relacionadas a LULUCF, o mecanismo financeiro da Convenção, comunicações nacionais do Anexo I, e o Artigo 6 da Convenção que trata sobre educação e treinamento.

Dentre os assuntos que foram tratados, destacam-se dois como de principal interesse para o Brasil: (i) as decisões sobre os procedimentos e modalidades simplificadas para os Projetos Florestais de Pequena Escala no Mecanismo de Desenvolvimento Limpo (PFPE/MDL) e (ii) as Comunicações Nacionais do Brasil e da China, contendo os inventários de emissões de Gases de Efeito Estufa - GEEs.

Os Projetos Florestais de Pequena Escala do MDL, já definidos durante a COP 9 (Milão, 2003) se caracterizam basicamente por serem desenvolvidos e implementados por comunidades e indivíduos de baixa renda e que não ultrapassem a captação ou "seqüestro" anual de 8.000 toneladas de CO2 equivalente.

Durante a COP 10 foi adotado um pacote de regras que busca reduzir os custos operacionais e transacionais destes projetos, podendo viabilizar sua implantação em pequenas áreas. O documento que estabelece tais regras foi encaminhado à Junta Executiva do MDL, que deverá criar padrões e metodologias simplificadas para serem aplicados aos projetos. 
As Comunicações Nacionais, divulgadas pelo Brasil e pela China durante o evento, eram ansiosamente aguardadas, uma vez que ambos os países não possuem metas de redução para o primeiro período do compromisso (2008 a 2012) e se constituem, ao lado da Índia, como os países com maior potencial de geração de créditos de carbonos oriundos de projetos de MDL. A Convenção do Clima (CQNUMC) dita que os principais responsáveis pelo aquecimento global são os países industrializados, chamados de partes do Anexo I, estando, portanto, para o primeiro período de compromisso, apenas estes países incumbidos de metas obrigatórias de redução de emissões.

No entanto, devido ao processo de desenvolvimento econômico, alguns países, como Brasil, China e Índia, têm apresentado um alto grau de emissão de gases do efeito estufa, fato evidenciado pela divulgação de seus respectivos inventários de emissões, durante as Comunicações Nacionais na COP 10.

Segundo o inventário brasileiro (ano base de $1994^{51}$ ), o Brasil emitiu cerca de 1 bilhão de toneladas de dióxido de carbono. Dessa quantia, 75\% das emissões foram provenientes de mudanças na cobertura vegetal e uso da terra, caracterizadas principalmente pela conversão de áreas florestais em agricultura, localizadas em sua maioria na Amazônia. Os 25\% restantes das emissões foram provenientes da queima de combustíveis fósseis para gerar energia e transporte.

A China, segundo seu inventário, emitiu, para o ano-base de 1994, cerca de 3 bilhões de toneladas de CO2 provenientes do setor de energia e industrial, porém as atividades e mudanças no uso da terra apresentaram uma remoção de cerca de 407 milhões de toneladas de $\mathrm{CO} 2$, resultando em um balanço geral de emissão de aproximadamente 2,6 bilhões de toneladas de CO2.

\footnotetext{
${ }^{51}$ BRASIL. Ministério da Ciência e Tecnologia. Inventário de Emissões e Remoções Antrópicas de Gases de Efeito Estufa não controlados pelo Protocolo de Montreal . Comunicação Inicial do Brasil. 2005. http://www.mct.gov.br/index.php/content/view/17351.html. Acessado em 20 de abril de 2007.
} 


\subsubsection{Conferência das Partes 11 - Reunião das Partes 1 (MOP 1)}

A décima primeira Conferência das Partes e a primeira Conferência das Partes na qualidade de reunião das Partes do Protocolo de Kyoto (COP/MOP 1) aconteceu em Montreal, no Canadá, de 28 de novembro a 10 de dezembro de 2005. O evento reuniu cerca de 9.500 participantes, incluindo 2.800 oficiais de governos.

Na COP/MOP 1, as Partes discutiram e adotaram decisões operacionais do Protocolo de Kyoto, incluindo um pacote de decisões conhecido como Acordo de Marrakesh. Essas decisões contêm guias de como o Protocolo funcionará, como as relacionadas aos mecanismos flexíveis, que pretendem ajudar as Partes a alcançar suas metas de redução em conformidade com o mecanismo.

A COP/MOP 1 também apresentou discussões relativas ao período pós2012, quando o primeiro período de compromissos de reduções termina. Decidiuse iniciar um processo por um grupo Ad Hoc para considerar compromissos pelo Anexo I além de 2012, e que o grupo deverá terminar seu trabalho e ter novos compromissos adotados em tempo hábil para que não haja lacunas entre os períodos de compromisso.

A COP 11 endereçou questões relativas ao desenvolvimento e transferência de tecnologia, efeitos adversos das mudanças climáticas nos países em desenvolvimento, e várias questões relacionadas a orçamento e financiamento, incluindo diretrizes para o Global Environment Facility (GEF), que serve como o mecanismo financeiro da Convenção.

\subsubsection{Conferência das Partes 12 - Reunião das Partes 2 (MOP 2)}

A décima segunda Conferência das Partes e a segunda Conferência das Partes na qualidade de reunião das Partes do Protocolo de Kyoto (COP/MOP 2) aconteceu em Nairóbi, no Quênia, entre os dias 6 e 17 de novembro de 2006.

O principal foco da COP/MOP 2 da COP 12 foi a discussão de ações de longo prazo sobre a questão das mudanças climáticas e no desenvolvimento de um quadro de ações uma vez que o primeiro período de compromissos estipulado pelo Protocolo de Kyoto termina em 2012. 
$\mathrm{Na}$ COP/MOP 2, as Partes examinaram questões relativas aos mecanismos financeiros do Protocolo de Kyoto, particularmente o Mecanismo de Desenvolvimento Limpo e a Implementação Conjunta

A COP 12 reviu a implementação de compromissos e outras provisões da Convenção em relação ao mecanismo financeiro, às comunicações nacionais, transferência de tecnologia, e os efeitos adversos das mudanças climáticas.

Um dos pontos de destaque da Conferência foi a aprovação da criação de um fundo para financiar a adaptação de países pobres aos efeitos das mudanças climáticas. O fundo de adaptação será formado com uma parcela dos recursos gerados no âmbito do Mecanismo de Desenvolvimento Limpo (MDL), e seu funcionamento será definido na COP 13/MOP 3, que realizar-se-á na Indonésia.

As incertezas quanto à interferência humana no sistema climático pela emissão de GEE provenientes, principalmente, de atividades que utilizam combustíveis fósseis, foram dissipadas com as publicações dos estudos do IPCC. O último relatório traz evidências concretas de que as mudanças vêm ocorrendo e suas conseqüências serão desastrosas à humanidade. Dessa forma, para garantir a segurança ambiental é necessário que sejam tomadas medidas em escala mundial.

O estabelecimento da Convenção Quadro de Mudanças Climáticas permitiu a discussão do aquecimento global e suas conseqüências em escala mundial, delegando responsabilidades comuns, porém diferenciadas a todos os Estados. Esse nível de discussão demonstra claramente que as questões ambientais ganharam espaço na agenda internacional, o que é muito positivo e reflete uma possibilidade de ações mais eficazes rumo a uma mudança de paradigma da sociedade. É claro que esse é um processo muito lento e que pressupõe muita discussão - visto que antes da entrada em vigor do Protocolo de Kyoto em 2005, por exemplo, foram realizadas 10 COPs. Porém, esse resultado pode ser considerado um sucesso, dado o número de Estados participantes apesar do latente conflito de interesses.

No capítulo 3 discutiremos o Protocolo de Kyoto, os mecanismos de flexibilidade estabelecidos para o cumprimento das reduções de emissões - em especial o Mecanismo de Desenvolvimento Limpo - e o mercado de carbono 
criado para comercializar os Certificados de Reduções Emitidas resultantes dos projetos de MDL. 


\section{CAPÍTULO 3: O PROTOCOLO DE KYOTO E OS MECANISMOS DE FLEXIBILIZAÇÃO}

O Capítulo 3, denominado O Protocolo de Kyoto e os mecanismos de flexibilização, abordará com base nos documentos pesquisados, a constituição do instrumento da Convenção Quadro de Mudanças Climáticas que permite aos Países Anexo I os meios de cumprirem as metas de redução de emissões de dióxido de carbono.

O Protocolo de Kyoto estabeleceu mecanismos de flexibilidade, dos quais destacamos o Mecanismo de Desenvolvimento Limpo, que permite aos Países do Anexo I investir em projetos nos países em desenvolvimento (Não Anexo I) que resultem em redução ou fixação de $\mathrm{CO} 2$. Essas reduções de emissões são chamadas de Certificados de Emissões Reduzidas e servem para que os países Anexo I possam cumprir suas metas de redução.

O desenvolvimento desses projetos permitiu a criação do chamado mercado de carbono, no qual países como China, índia e Brasil apresentam destaque.

Apresentaremos um panorama geral dos aspectos citados, dos projetos desenvolvidos no âmbito do MDL e dos valores comercializados neste novo mercado.

\subsection{O Protocolo de Kyoto}

O Protocolo de Kyoto foi adotado por meio da Decisão 1/CP.3 na Conferência das Partes 3 realizada em Kyoto, no Japão. O Protocolo, como dito anteriormente, é composto de 28 artigos e 2 anexos, e sua publicação inclui três decisões tomadas pela COP 3 e uma tabela, que fornece informações importantes para sua adoção e implementação. Em seu Artigo 13.1, estabelece que a Conferência das Partes da Convenção (COP) deve atuar como Reunião das Partes (MOP) do Protocolo, o que resulta na conjunção COP/MOP; no Artigo 14.1, estabelece que o Secretariado da Convenção deve atuar ainda como Secretariado do Protocolo e em seu Artigo 15.1 estabelece que o SBSTA e o SBI 
devem atuar como órgãos subsidiários também do Protocolo. Em 1998, o Protocolo de Kyoto é aberto para adesões, e recebe em um ano 84 assinaturas.

Em seu Artigo 3.1, o Protocolo estabelece que

"As Partes incluídas no Anexo I devem, individual ou conjuntamente, assegurar que suas emissões antrópicas agregadas, expressas em dióxido de carbono equivalente, dos gases de efeito estufa listados no Anexo A não excedam suas quantidades atribuídas, calculadas em conformidade com seus compromissos quantificados de limitação e redução de emissões descritos no Anexo B e de acordo com as disposições deste Artigo, com vistas a reduzir suas emissões totais desses gases em pelo menos 5\% abaixo dos níveis de 1990 no período de compromisso de 2008 a 2012." ${ }^{n 2}$

Em seu Anexo A, o Protocolo estabelece seis gases de efeito estufa, como já citado anteriormente: dióxido de carbono $\left(\mathrm{CO}_{2}\right)$, metano $\left(\mathrm{CH}_{4}\right)$, óxido nitroso $\left(\mathrm{N}_{2} \mathrm{O}\right)$, hidrofluorcarbonos (HFCs), perfluorcarbonos (PFCs) e hexafluoreto de enxofre $\left(\mathrm{SF}_{6}\right)$. Estes gases foram escolhidos por serem os mais importantes relacionados a atividades antrópicas, e dentre estes o $\mathrm{CO}_{2}$ é o mais importante.

Os compromissos de redução foram estabelecidos de forma diferenciada às Partes do Anexo I, conforme descrito no Artigo 3.7,

"No primeiro período de compromissos quantificados de limitação e redução de emissões, de 2008 a 2012, a quantidade atribuída para cada Parte incluída no Anexo I deve ser igual à porcentagem descrita no Anexo $B$ de suas emissões antrópicas agregadas, expressas em dióxido de carbono equivalente, dos gases de efeito estufa listados no Anexo A em 1990, ou o ano ou período de base determinado em conformidade com o parágrafo 5 , multiplicado por cinco.(...)"53

\footnotetext{
${ }^{52}$ BRASIL. Ministério da Ciência e Tecnologia. Protocolo de Kyoto - Texto editado e traduzido pelo Ministério da Ciência e Tecnologia com apoio do Ministério das Relações Exteriores da República Federativa do Brasil.1997, p. 6. Disponível em: http://www.mct.gov.br/index.php/content/view/28739.html. Acessado em 22/11/2006 ${ }^{53}$ BRASIL. Ministério da ciência e tecnologia. Texto da Convenção-Quadro das Nações Unidas sobre Mudança do Clima. Editado e traduzido pelo Ministério da Ciência e Tecnologia com o apoio do Ministério das Relações Exteriores da República Federativa do Brasil. Artigo 2. p. 7. http://www.mct.gov.br/index.php/content/view/4120.html. Acessado em 22/11/2005.
} 
É importante ressaltar que as metas de redução diferenciadas foram estabelecidas de forma política, na qual cada país ofereceu suas metas, cujas magnitudes foram influenciadas pela habilidade dos negociadores em defender seus interesses. Estas metas não guardam qualquer relação de proporcionalidade com os níveis de emissão. Portanto, para algumas Partes é permitido um crescimento das emissões.

Tabela 5: Anexo B do Protocolo de Kyoto - Compromisso de redução ou limitação quantificada de emissões (porcentagem do ano base ou período)

\begin{tabular}{|l|l|l|l|}
\hline Alemanha & 92 & Islândia & 110 \\
\hline Austrália & 108 & Itália & 92 \\
\hline Áustria & 92 & Japão & 94 \\
\hline Bélgica & 92 & Letônia* & 92 \\
\hline Bulgária* & 92 & Liechtenstein & 92 \\
\hline Canadá & 94 & Lituânia* & 92 \\
\hline Comunidade Econômica Européia & 92 & Luxemburgo & 92 \\
\hline Croácia* & 95 & Mônaco & 92 \\
\hline Dinamarca & 92 & Noruega & 101 \\
\hline Eslováquia* & 92 & Nova Zelândia & 100 \\
\hline Eslovênia* & 92 & Países Baixos & 92 \\
\hline Espanha & 92 & Polônia* & 94 \\
\hline Estados Unidos & 93 & Portugal & 92 \\
\hline Estônia* & 92 & Reino Unido da Grã-Bretanha e Irlanda do Norte & 92 \\
\hline Federação Russa* & 92 \\
\hline Finlândia & 100 & República Tcheca* & 92 \\
\hline França & 92 & Romênia* & 92 \\
\hline Grécia & 92 & Suécia & 92 \\
\hline Hungria* & 92 & Suíça & 92 \\
\hline Irlanda & 94 & Ucrânia* & 100 \\
\hline
\end{tabular}

Fonte: BRASIL. Ministério da Ciência e Tecnologia. Protocolo de Kyoto - Texto editado e traduzido pelo Ministério da Ciência e Tecnologia com apoio do Ministério das Relações Exteriores da República Federativa do Brasil.1997, Anexo B. Disponível em: http://www.mct.gov.br/index.php/content/view/28739.html. Acessado em 22/11/2006.

* Países em processo de transição para uma economia de mercado

Em consonância com o que fora estabelecido pelo Mandato de Berlim, o Artigo 3.1 do Protocolo de Kyoto adiava para o ano de 2008 o prazo de início do primeiro período de compromisso de redução de emissões de GEE, limite este que havia sido previsto na Convenção para o ano de 2000. De acordo com o Artigo 25, o Protocolo de Kyoto: 
“(...) entra em vigor no nonagésimo dia após a data em que pelo menos 55 Partes da Convenção, englobando as Partes incluídas no Anexo I que contabilizaram no total pelo menos 55 por cento das emissões totais de dióxido de carbono em 1990 das Partes incluídas no Anexo I, tenham depositado seus instrumentos de ratificação, aceitação, aprovação ou adesão." ${ }^{54}$

Os Estados Unidos, com $36,1 \%$ do total de emissões de dióxido de carbono dos países do Anexo I em 1990, é o país que representa o maior nível de emissão, seguido pela Federação Russa com 17,4\% e do Japão, com 8,55\%. A decisão americana de abandonar as negociações poderia ter colocado em risco a existência do Protocolo, se tivesse sido acompanhada pela Rússia, já que juntos representariam $53,5 \%$ dos $55 \%$ a que se refere o Artigo 25 , necessários para que isso aconteça.

Tabela 6: Total de Emissões de CO2 em 1990, usado para fins do artigo 25 do Protocolo de Kyoto (partes componentes do Anexo I)*

\begin{tabular}{|c|c|c|}
\hline Parte & Emissões $\mathbf{( G g )}$ & Porcentagem do total (\%) \\
\hline Alemanha & 1.012 .443 & 7,4 \\
\hline Austrália & 288.965 & 2,1 \\
\hline Áustria & 59.200 & 0,4 \\
\hline Bélgica & 113.405 & 0,8 \\
\hline Bulgária & 82.990 & 0,6 \\
\hline Canadá & 457.441 & 3,3 \\
\hline Dinamarca & 52.100 & 0,4 \\
\hline Eslováquia & 58.278 & 0,4 \\
\hline
\end{tabular}

\footnotetext{
${ }^{54}$ BRASIL. Ministério da Ciência e Tecnologia. Protocolo de Kyoto - Texto editado e traduzido pelo Ministério da Ciência e Tecnologia com apoio do Ministério das Relações Exteriores da República Federativa do Brasil.1997, p. 21. Disponível em:

http://www.mct.gov.br/index.php/content/view/28739.html. Acessado em 22/11/2006.
} 


\begin{tabular}{|c|c|c|}
\hline Espanha & 260.654 & 1,9 \\
\hline EUA & 4.957 .022 & 36,1 \\
\hline Estônia & 37.797 & 0,3 \\
\hline Rússia & 2.388 .720 & 17,4 \\
\hline Finlândia & 53.900 & 0,4 \\
\hline França & 366.536 & 2,7 \\
\hline Grécia & 82.100 & 0,6 \\
\hline Hungria & 71.673 & 0,5 \\
\hline Irlanda & 30.719 & 0,2 \\
\hline Islândia & 2.172 & 0 \\
\hline Itália & 428.941 & 3,1 \\
\hline Japão & 1.173 .360 & 8,5 \\
\hline Letônia & 22.976 & 0,2 \\
\hline Liechtenstein & 208 & 0 \\
\hline Luxemburgo & 11.343 & 0,1 \\
\hline Mônaco & 71 & 0 \\
\hline Noruega & 355.331 & 0,3 \\
\hline Nova Zelândia & 25.530 & 0,2 \\
\hline Países Baixos & 167.600 & 1,2 \\
\hline Polônia & 414.930 & 3 \\
\hline Portugal & 42.148 & 0,3 \\
\hline UK & 584.078 & 0,3 \\
\hline República Tcheca & 169.514 & 4,3 \\
\hline Romênia & 171.103 & 1,2 \\
\hline Suécia & 61.256 & 0,4 \\
\hline Suíça & 43.600 & 0,3 \\
\hline Total & 13.728.306 & 100 \\
\hline
\end{tabular}

Dados baseados em informações recebidas das 34 Partes do Anexo I que submeteram suas primeiras comunicações nacionais em 11 de dezembro de 1997 ou antes dessa data, compiladas pelo Secretariado em vários documentos (A/AC.237/81; FCCC/CP/1996/12/Add.2 
e FCCC/SB/1997/6). Algumas das comunicações continham dados sobre as emissões de CO2 por fontes e remoções por sumidouros resultantes de mudança no uso da terra e florestas, porém esses dados não foram incluídos porque as informações foram relatadas de diferentes modos.

Fonte: BRASIL. Ministério da Ciência e Tecnologia. Protocolo de Kyoto - Texto editado e traduzido pelo Ministério da Ciência e Tecnologia com apoio do Ministério das Relações Exteriores da República Federativa do Brasil.1997. Disponível em:

http://www.mct.gov.br/index.php/content/view/28739.html. Acessado em 22/11/2006.

Em 04 de novembro de 2004 o presidente da Rússia, Vladimir Puttin ratificou o Protocolo de Kyoto, permitindo que o mesmo entrasse em vigor no dia 16 de fevereiro de 2005.

A aprovação e entrada em vigor do Protocolo de Kyoto estabeleceu alguns princípios, dentre os quais o da precaução, o da responsabilidade comum, porém, diferenciada, e o do poluidor pagador, discutidos no Capítulo 1 desta dissertação. Cabe-nos apenas lembrar que o princípio da precaução estabelece que mesmo na ausência de elevado grau de confiabilidade nas previsões, e levando-se em conta a magnitude dos efeitos adversos, devem ser tomadas medidas de prevenção de modo a evitar o agravamento do efeito. $O$ princípio da responsabilidade comum, porém diferenciada estabelece que, embora seja global o problema ambiental, caberia aos países tradicionalmente industrializados e historicamente responsáveis pelos danos ambientais (reunidos no Anexo I), o ônus por evitar seu agravamento. O princípio do poluidor pagador obriga quem poluiu a pagar pela poluição causada ou que pode ser causada.

O protocolo de Kyoto é um importante resultado e instrumento de ação em escala mundial para a mitigação dos impactos ambientais decorrentes das ações humanas. Trata-se de um instrumento inovador que promove ações que rompem com o modelo estabelecido, estimulando um desenvolvimento em bases socioambientais menos impactantes, menos desiguais.

A concepção do Protocolo e sua entrada em vigor mudam também, de certa forma, as relações de poder entre os Estados. O principal emissor de GEE do mundo (e influenciador da ordem mundial) não faz parte do Protocolo e mesmo assim ele está vigorando, o que demonstra que já houve a sensibilização para uma tomada de atitude. É claro que nesta tomada de atitude também estão implícitos os interesses de cada país. A EU, por exemplo, que corre o risco de ter 
grande parte de sua área coberta pelo mar se os níveis dos oceanos aumentarem, está atuando ativamente para que os objetivos do Protocolo sejam atingidos.

Sabemos que o primeiro período de redução não será suficiente para reverter o quadro de alterações climáticas instalado, mas é um importante referencial em se tratando de discussões em escala mundial. Cabe agora verificar se as metas de redução serão cumpridas, se as penalidades àqueles que não as cumprirem serão aplicadas e, principalmente imprimir esforços para que as discussões sobre o pós-2012 obtenham êxito.

\subsection{Os Mecanismos de Flexibilidade}

O Protocolo de Kyoto é inovador ao introduzir mecanismos de flexibilidade para auxiliar os países do Anexo I no cumprimento das metas de redução de emissões de dióxido de carbono. Estes mecanismos permitem que um país do Anexo I adquira certificados de emissão reduzida por meio da aquisição direta ou por investimentos em projetos em outros países. Ao permitir que o abatimento de GEE seja realizado além das fronteiras nacionais, os mecanismos ampliam as opções disponíveis aos países do Anexo I e conferemIhe um grau de flexibilidade. Essa flexibilidade permite alcançar os objetivos finais da Convenção que é a estabilização da concentração atmosférica de GEE.

Dessa forma, o Protocolo de Kyoto possibilitou a abertura de um mercado de créditos de carbono (assim também conhecido os certificados de emissões reduzidas de dióxido de carbono), ou seja, criar um valor transacionável para as reduções dos GEE passível de ser comercializável na bolsa de valores. A adoção dos mecanismos de flexibilidade está ligada ao princípio do poluidorpagador, ou seja, o causador da poluição deve arcar com os custos necessários à diminuição, eliminação ou neutralização deste dano. Os países do Anexo I podem comprar os créditos de carbono e pagar pelo dano causado.

O Protocolo de Kyoto estabeleceu três mecanismos de flexibilidade: conhecidos como implementação conjunta (Joint Implementation - Jl), comércio 
de emissões (Emissions Trade) e o mecanismo de desenvolvimento limpo (MDL). Dos três mecanismos, o que nos interessa diretamente é o mecanismo de desenvolvimento limpo, sendo nosso objeto de estudo resultado desta iniciativa, porém analisaremos de forma sucinta os outros dois mecanismos.

\subsubsection{Artigo 6: Implementação Conjunta}

A Implementação Conjunta, prevista no Artigo 6 do texto do Protocolo de Kyoto, permite aos países desenvolvidos/industrializados atingir suas metas de redução por meio do financiamento de projetos que reduzam as emissões em países também industrializados pertencentes ao Anexo I. Os países financiadores receberão os créditos que podem ser contabilizados às metas de redução que devem atingir; e os países nos quais os projetos são desenvolvidos recebem, portanto, investimentos e tecnologia avançada, mas não podem usar os créditos gerados para suas próprias metas de redução. O sistema tem as vantagens da flexibilidade e eficiência. É frequentemente mais barato implementar projetos de eficiência energética, nos países em economias de transição, e com isso alcançar maiores índices de redução de GEE. Dado que os benefícios à atmosfera independem de onde os projetos estão alocados.

Os Projetos devem ser aprovados pelas Partes envolvidas e devem promover mitigação adicional à que ocorreria na ausência do projeto. Além disso, a aquisição dos certificados de emissões reduzidas deve ser suplementar às ações domésticas realizadas com o fim de cumprir os compromissos previstos no Artigo 3 do Protocolo.

\subsubsection{Artigo 17: Comércio de Emissões}

O Comércio de Emissões está previsto no Artigo 17 do Protocolo de Kyoto, conforme segue

"A Conferência das Partes deve definir os princípios, as modalidades, regras e diretrizes apropriados, em particular para verificação, elaboração de relatórios e prestação de contas do comércio de emissões. As Partes incluídas no Anexo B podem participar do comércio de emissões 
com o objetivo de cumprir os compromissos assumidos sob o Artigo 3. Tal comércio deve ser suplementar às ações domésticas com vistas a atender os compromissos quantificados de limitação e redução de emissões, assumidos sob esse Artigo." 55

O Protocolo de Kyoto permite aos países do Anexo $B$, que tenham excedente de unidades de redução, vendê-las aos países que não atingiram suas metas de redução. Mas os preços no mercado de carbono podem ser elevados, e quanto mais elevado o custo para aquisição dos créditos de carbono, maior será a pressão para que os países do Anexo B utilizem eficientemente a energia e promovam o desenvolvimento de fontes alternativas de energia que tenham baixa emissão de GEE.

O mercado de carbono é um conceito simples, porém sua implementação pode ser complicada, pois os detalhes não foram especificados no Protocolo e as emissões reais dos países devem ser monitoradas garantindo que haja veracidade nas informações prestadas sobre as reduções, além de registros do comércio realizado.

Antes da entrada em vigor do Tratado de Kyoto, em vários países já haviam sido criados mercados domésticos para a comercialização dos futuros CERs. Entre eles destacam-se: Emissions Trading Scheme, do Reino Unido, CERUPT/ERUPT do governo holandês, Chicago Climate Exchange, Prototype Carbon Fund do Banco Mundial e BioCarbon Fund do Banco Mundial para projeto de LULUCF.

\subsubsection{Artigo 12: Mecanismo de Desenvolvimento Limpo}

O Mecanismo de Desenvolvimento Limpo nasceu de uma proposta brasileira apresentada ao Grupo Ad Hoc para o Mandato de Berlim, em maio de 1997, no processo de negociação que resultou no Protocolo de Kyoto. Segundo MIGUEZ, o documento apresentado pelo Brasil,

\footnotetext{
${ }^{55}$ BRASIL. Ministério da Ciência e Tecnologia. Protocolo de Kyoto - Texto editado e traduzido pelo Ministério da Ciência e Tecnologia com apoio do Ministério das Relações Exteriores da República Federativa do Brasil.1997. p. 18. Disponível em: http://www.mct.gov.br/index.php/content/view/28739.html. Acessado em 22/11/2006.
} 
“(...) intitulado "Elementos propostos de um protocolo para a Convenção-Quadro das Nações Unidas sobre Mudança do Clima, apresentados pelo Brasil em resposta ao Mandato de Berlim (documento FCCC/AGBM/1997/Misc 1/Add 3)" submetido ao Secretariado da Convenção, em maio de 1997, apresentou dois elementos para discussão em relação ao processo do Mandato de Berlim. O primeiro elemento visava estabelecer a responsabilidade individual dos países em termos de causar o efeito estufa. O segundo elemento estabelecia a idéia de um Fundo de Desenvolvimento Limpo para substituir o conceito de atividades implementadas conjuntamente, que tinha pouca adesão de países em desenvolvimento. A quantificação do princípio das responsabilidades comuns, mas diferenciadas, era uma das metas básicas e subjacentes da proposta." ${ }^{\text {"56 }}$

O segundo ponto estabelecido pela proposta brasileira era a idéia de um Fundo de Desenvolvimento Limpo para substituir as atividades implementadas conjuntamente. Esse fundo foi concebido como forma de acabar com o impasse da inação, promovendo a transferência de tecnologia e provendo os recursos financeiros necessários para que os países em desenvolvimento contribuíssem ativamente na mitigação da mudança do clima.

A idéia básica da proposta brasileira era criar uma penalidade pelo não cumprimento das metas dos países desenvolvidos. A penalidade foi proposta tendo como base o aumento de temperatura adicional que pode ser atribuído a um país que tenha falhado em alcançar as metas estabelecidas de redução ou limitação de emissões.

Os recursos financeiros do fundo de desenvolvimento limpo seriam disponibilizados para os países não-Anexo I para uso em projetos de mitigação e adaptação à mudança do clima, de acordo com as diretrizes a serem estabelecidas pela Convenção. Também foi proposto que a parcela do fundo alocada para projetos de adaptação à mudança do clima correspondesse a uma pequena porcentagem dos fundos disponíveis, definindo claramente as

\footnotetext{
${ }^{56}$ MIGUEZ, José Domingos González. O Mecanismo de Desenvolvimento Limpo: a proposta e as perspectivas brasileiras. Trabalho apresentado no evento "Sustentabilidade na Geração e Uso da Energia no Brasil: os Próximos Vinte Anos. Unicamp, 2002.p. 4.
} 
prioridades de uso dos recursos financeiros para projetos de mitigação, concebida para dar apoio aos esforços dos países menos desenvolvidos de adaptarem-se à mudança do clima.

Os Estados Unidos manifestaram alguma objeção à idéia de um fundo de desenvolvimento limpo. Havia duas razões principais para isso. Primeiro, a idéia de penalidade criaria um precedente não existente em um tratado internacional. Segundo, era um sentimento comum que a idéia do fundo associado a recursos orçamentários não criaria incentivos para uma forte ação do setor privado dos países desenvolvidos.

As idéias do governo dos Estados Unidos foram discutidas no Rio de Janeiro em novembro de 1997 em uma reunião preparatória (para a COP 3), antes de Kyoto, e uma proposta conjunta incorporando as preocupações de ambos os lados foi acordada. A idéia original de um fundo foi modificada e transformada em um mecanismo de desenvolvimento limpo, durante essas negociações. A proposta modificada durante as sessões da Conferência das Partes em Kyoto, envolvendo outras Partes interessadas, foi finalmente aprovada em Kyoto e adotada como o Artigo 12 do Protocolo que estabelece o Mecanismo de Desenvolvimento Limpo,

1. "Fica definido um mecanismo de desenvolvimento limpo.

2. O objetivo do mecanismo de desenvolvimento limpo deve ser assistir às Partes não incluídas no Anexo I para que atinjam o desenvolvimento sustentável e contribuam para o objetivo final da Convenção, e assistir às Partes incluídas no Anexo I para que cumpram seus compromissos quantificados de limitação e redução de emissões, assumidos no Artigo 3.

3. "Sob o mecanismo de desenvolvimento limpo:

a. As Partes não incluídas no Anexo I beneficiar-se-ão de atividades de projetos que resultem em reduções certificadas de emissões; e,

b. As Partes incluídas no Anexo I podem utilizar as reduções certificadas de emissões resultantes de tais atividades de projetos, para contribuir com 0 
cumprimento de parte de seus compromissos quantificados de limitação e redução de emissões, assumidos no Artigo 3, como determinado pela Conferência das Partes na qualidade de reunião das Partes deste Protocolo.

4. O mecanismo de desenvolvimento limpo deve sujeitar-se à autoridade e orientação da Conferência das Partes na qualidade de reunião das Partes deste Protocolo e à supervisão de um conselho executivo do mecanismo de desenvolvimento limpo.

5. As reduções de emissões resultantes de cada atividade de projeto devem ser certificadas por entidades operacionais a serem designadas pela Conferência das Partes na qualidade de reunião das Partes deste Protocolo, com base em:

a. Participação voluntária aprovada por cada Parte envolvida;

b. Benefícios reais, mensuráveis e de longo prazo relacionados com a mitigação da mudança do clima, e

c. Reduções de emissões que sejam adicionais as que ocorreriam na ausência da atividade certificada de projeto.

6. O mecanismo de desenvolvimento limpo deve prestar assistência quanto à obtenção de fundos para atividades certificadas de projetos quando necessário.

7. A Conferência das Partes na qualidade de reunião das Partes deste Protocolo deve, em sua primeira sessão, elaborar modalidades e procedimentos com o objetivo de assegurar transparência, eficiência e prestação de contas das atividades de projetos por meio de auditorias e verificações independentes.

8. A Conferência das Partes na qualidade de reunião das Partes deste Protocolo deve assegurar que uma fração dos fundos advindos de atividades de projetos certificadas seja utilizada para cobrir despesas administrativas, assim como assistir às Partes países em desenvolvimento que sejam particularmente vulneráveis aos efeitos adversos da mudança do clima para fazer face aos custos de adaptação.

9. A participação no mecanismo de desenvolvimento limpo, incluindo nas atividades mencionadas no parágrafo 3 (a) acima e na 
aquisição de reduções certificadas de emissão, pode envolver entidades privadas e/ou públicas e deve sujeitar-se a qualquer orientação que possa ser dada pelo conselho executivo do mecanismo de desenvolvimento limpo.

10. Reduções certificadas de emissões obtidas durante o período do ano 2000 até o início do primeiro período de compromisso podem ser utilizadas para auxiliar no cumprimento das responsabilidades relativas ao primeiro período de compromisso." ${ }^{57}$

Dessa forma, a proposta do Mecanismo de Desenvolvimento Limpo é de prestar assistência às Partes Não Anexo I para que viabilizem o desenvolvimento sustentável por meio da implantação de projetos que contribuam para o objetivo final da Convenção, e ao mesmo tempo, prestar assistência às Partes Anexo I para que cumpram seus compromissos quantificados de limitação e redução de emissões de GEE. O objetivo final da Convenção é atingido por meio da implementação de atividades nos países em desenvolvimento que resultem em redução ou remoção de $\mathrm{CO}_{2}$, mediante investimentos em tecnologias mais eficientes, substituição de base energética, racionalização do uso da energia, florestamento e reflorestamento.

Podem participar de um projeto de MDL as Partes do Anexo I, Partes Não Anexo I ou entidades públicas e privadas dessas Partes, desde que por elas devidamente autorizadas. As atividades de projeto do MDL podem ser implementadas por meio de parcerias com o setor público ou privado.

Para que sejam consideradas elegíveis no âmbito do MDL, as atividades de projeto devem contribuir com o objetivo primordial da Convenção e observar alguns critérios fundamentais, entre os quais o da adicionalidade, pelo qual a atividade de projeto deve, comprovadamente, resultar na redução de emissões de GEE e/ou remoção de $\mathrm{CO}_{2}$ adicional ao que ocorreria na ausência da atividade de projeto do MDL. Outro requisito do MDL é que a atividade de projeto contribua para o desenvolvimento sustentável do país no qual venha ser implementada.

\footnotetext{
${ }^{57}$ BRASIL. Ministério da Ciência e Tecnologia. Protocolo de Kyoto - Texto editado e traduzido pelo Ministério da Ciência e Tecnologia com apoio do Ministério das Relações Exteriores da República Federativa do Brasil.1997. p. 14-15. Disponível em:

http://www.mct.gov.br/index.php/content/view/28739.html. Acessado em 22/11/2006.
} 
Deve, ainda, ser capaz de demonstrar benefícios reais, mensuráveis e de longo prazo relacionados com a mitigação da mudança climática.

As atividades de projeto do MDL deverão ser submetidas a um processo de aferição e verificação por meio de instituições e procedimentos. As instituições relacionadas ao MDL são as seguintes:

- Conselho Executivo: supervisiona o funcionamento do MDL. Entre suas responsabilidades destacam-se: a) o credenciamento das Entidades Operacionais Designadas; b) registro das atividades de projeto do MDL; c) emissão de CERs; d) desenvolvimento e operação do Registro do MDL; e) estabelecimento e aperfeiçoamento de metodologias para definição da linha de base, monitoramento e fugas.

- Autoridade Operacional Designada: os governos dos países participantes de projeto de MDL devem designar junto à Convenção uma Autoridade Nacional, responsável por atestar que a participação dos países é voluntária e, que as atividades de projeto contribuem para o desenvolvimento sustentável do país, a quem cabe decidir, de forma soberana, se este objetivo do MDL está sendo cumprido. O PDD deve ser aprovado pela Autoridade Nacional Designada. No Brasil a Autoridade Nacional Designada é a Comissão Interministerial de Mudança Global do Clima, estabelecida por Decreto Presidencial em 7 de julho de 1999.

- Entidades Operacionais Designadas: são entidades/empresas nacionais ou internacionais credenciadas pelo Conselho Executivo e designadas pela COP, responsáveis por validar atividades de projetos de MDL de acordo com as decisões de Marrakesh; verificar e certificar reduções de emissões de GEE e remoções de $\mathrm{CO}_{2} \mathrm{e}$; enviar um relatório anual ao Conselho Executivo; manter disponíveis para o público as informações sobre as atividades de projetos de MDL, que não sejam consideradas confidenciais pelos participantes dos projetos.

Para que um projeto resulte em reduções certificadas de emissões, as atividades de projeto devem, necessariamente, passar pelas etapas do ciclo do 
projeto, que são sete: elaboração de documento de concepção de projeto (Project Design Documento - PDD), usando metodologia de linha de base e plano de monitoramente aprovados; validação (verifica se o projeto está em conformidade com a regulamentação do Protocolo de Kyoto); aprovação pela Autoridade Nacional Designada; submissão ao Conselho Executivo para registro; monitoramento; verificação/certificação; e emissão de CERs segundo o acordo do projeto.

A elaboração do Documento de Concepção de Projeto - PDD é a primeira etapa do ciclo. Esse documento deverá incluir, entre outras coisas, a descrição: das atividades de projeto; dos participantes da atividade de projeto; da metodologia da linha de base; das metodologias para cálculo da redução de emissões de GEE e para o estabelecimento dos limites da atividade de projeto e das fugas; e do plano de monitoramento. Deve conter, ainda, a definição do período de obtenção de créditos, a justificativa para adicionalidade da atividade de projeto, o relatório de impactos ambientais, os comentários das partes interessadas e informações quanto à utilização de fontes adicionais de financiamento. Os responsáveis por essa etapa do processo são os participantes do projeto.

A validação é o segundo passo e corresponde ao processo de verificação independente de uma atividade de projeto por uma Entidade Operacional Designada - EOD, no tocante aos requisitos do MDL, com base no PDD. A aprovação, por sua vez, é o processo pelo qual a AND das Partes envolvidas confirmam a participação voluntária e a AND do país onde são implementadas as atividades de projeto do MDL atesta que dita atividade contribui para o desenvolvimento sustentável do país. No caso do Brasil, os projetos são analisados pelos integrantes da Comissão Interministerial, que avaliam o relatório de validação e a contribuição da atividade de projeto para o desenvolvimento sustentável do país, segundo cinco critérios básicos: distribuição de renda, sustentabilidade ambiental local, desenvolvimento das condições de trabalho e geração líquida de emprego, capacitação e desenvolvimento tecnológico, e integração regional e articulação com outros setores.

Registro é aceitação formal, pelo Conselho Executivo, de um projeto validado como atividade de projeto do MDL. A aprovação de projetos no Conselho 
Executivo do MDL é subseqüente à aprovação pela Autoridade Nacional Designada. A aprovação pela Comissão Interministerial é necessária para a continuidade dos projetos, mas não é suficiente para sua aprovação pelo Conselho Executivo, que analisa também a metodologia escolhida, a adicionalidade do projeto, entre outros aspectos. O registro é o pré-requisito para o monitoramento, a verificação/certificação e emissão das CERs relativas à atividade de projeto no âmbito do MDL.

O processo de monitoramento da atividade de projeto inclui o recolhimento e armazenamento de todos os dados necessários para calcular a redução das emissões de gases de efeito estufa, de acordo com a metodologia de linha de base estabelecida no PDD, que tenham ocorrido dentro dos limites da atividade de projeto e dentro do período de obtenção de créditos. Os participantes do projeto serão os responsáveis pelo processo de monitoramento.

A sexta etapa é a verificação/certificação. Verificação é o processo de auditoria periódico e independente para revisar os cálculos acerca da redução de emissões de gases de efeito estufa ou de remoção de CO2 resultantes de uma atividade de projeto do MDL que foram enviados ao Conselho Executivo por meio do PDD. Esse processo é feito com o intuito de verificar a redução de emissões que efetivamente ocorreu. Após a verificação, o Conselho Executivo certifica que uma determinada atividade de projeto atingiu um determinado nível de redução de emissões de gases de efeito estufa durante um período de tempo específico.

A etapa final é quando o Conselho Executivo tem certeza de que, cumpridas todas as etapas, as reduções de emissões de gases de efeito estufa decorrentes das atividades de projeto são reais, mensuráveis e de longo prazo e, portanto, podem dar origem a CERs. As CERs são emitidas pelo Conselho Executivo e creditadas aos participantes de uma atividade de projeto na proporção por eles definida.

O primeiro projeto de MDL registrado e validado em âmbito mundial pelo Comitê Executivo é o brasileiro NovaGerar, implementado na cidade de Nova Iguaçu no Rio de Janeiro, objeto deste trabalho.

O Brasil, assim como China e Índia, não fazem parte do Anexo I, e neste primeiro período de reduções não têm metas a cumprir. Dessa forma o MDL surge como uma oportunidade de captação de recursos em diversos segmentos, 
tais como: reforma dos setores de energia e transportes, promoção do uso de fontes energéticas renováveis, redução das emissões de metano no gerenciamento de resíduos e dos sistemas energéticos, proteção de florestas e outros sumidouros de carbono.

O número de projetos submetidos à validação dobra a cada 5 meses: 40 em setembro de 2004, 80 em fevereiro de 2005, 170 em julho de 2005, apenas 18 meses após a primeira submissão ${ }^{58}$.

De acordo com documento publicado pelo Ministério da Ciência e Tecnologia ${ }^{59}$, com dados atualizados até maio de 2007, um total de 1964 projetos encontravase em alguma fase do ciclo de projetos de $\mathrm{MDL}$, sendo 636 já registrados pelo Conselho Executivo, e 1328 em outras fases do ciclo. O Brasil ocupa o $3^{\circ}$ lugar em números de projetos de MDL, com 222 projetos (12\%), sendo que Índia ocupa o primeiro lugar com 636 e, em segundo, a China com 483 projeto. Esse números podem ser observados nos gráficos abaixo.

\section{Gráfico 4: Número de atividades de projeto do MDL}

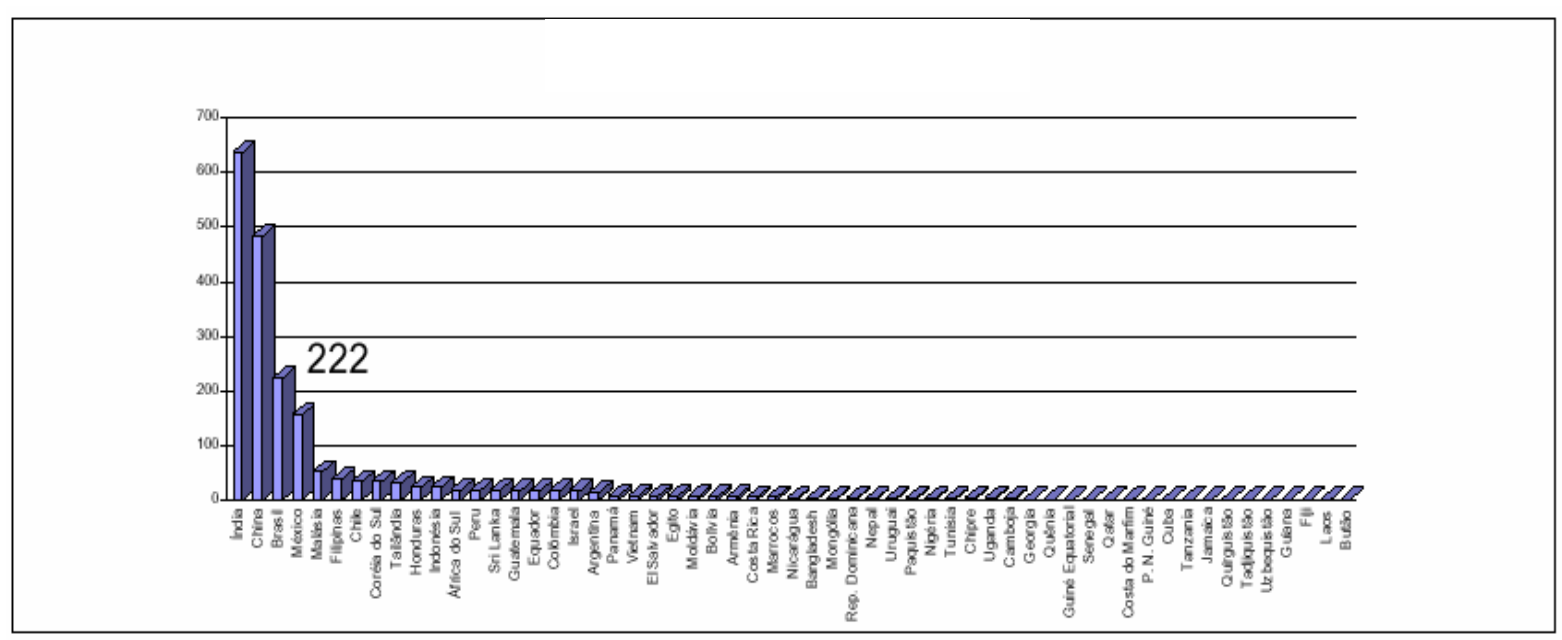

Fonte: BRASIL. Ministério da Ciência e Tecnologia. Status atual das atividades de projeto no âmbito do Mecanismo de Desenvolvimento Limpo (MDL) no Brasil e no mundo. Documento publicado pelo Ministério da Ciência e Tecnologia. p. 3. Disponível em: http://www.mct.gov.br/index.php/content/view/30317.html Acessado em 07/05/2007

\footnotetext{
${ }^{58}$ Fonte: Informações transmitidas pela ERM Consulting em agosto de 2006 durante curso sobre as oportunidades do Mecanismo de Desenvolvimento Limpo.

${ }^{59}$ BRASIL. Ministério da Ciência e Tecnologia. Status atual das atividades de projeto no âmbito do Mecanismo de Desenvolvimento Limpo (MDL) no Brasil e no mundo. Documento publicado pelo Ministério da Ciência e $\quad$ Tecnologia. Disponível em: http://www.mct.gov.br/index.php/content/view/30317.html Acessado em 07/05/2007
} 
Gráfico 5: Total de Atividades de Projeto do MDL no Mundo (total: 1964 projetos)

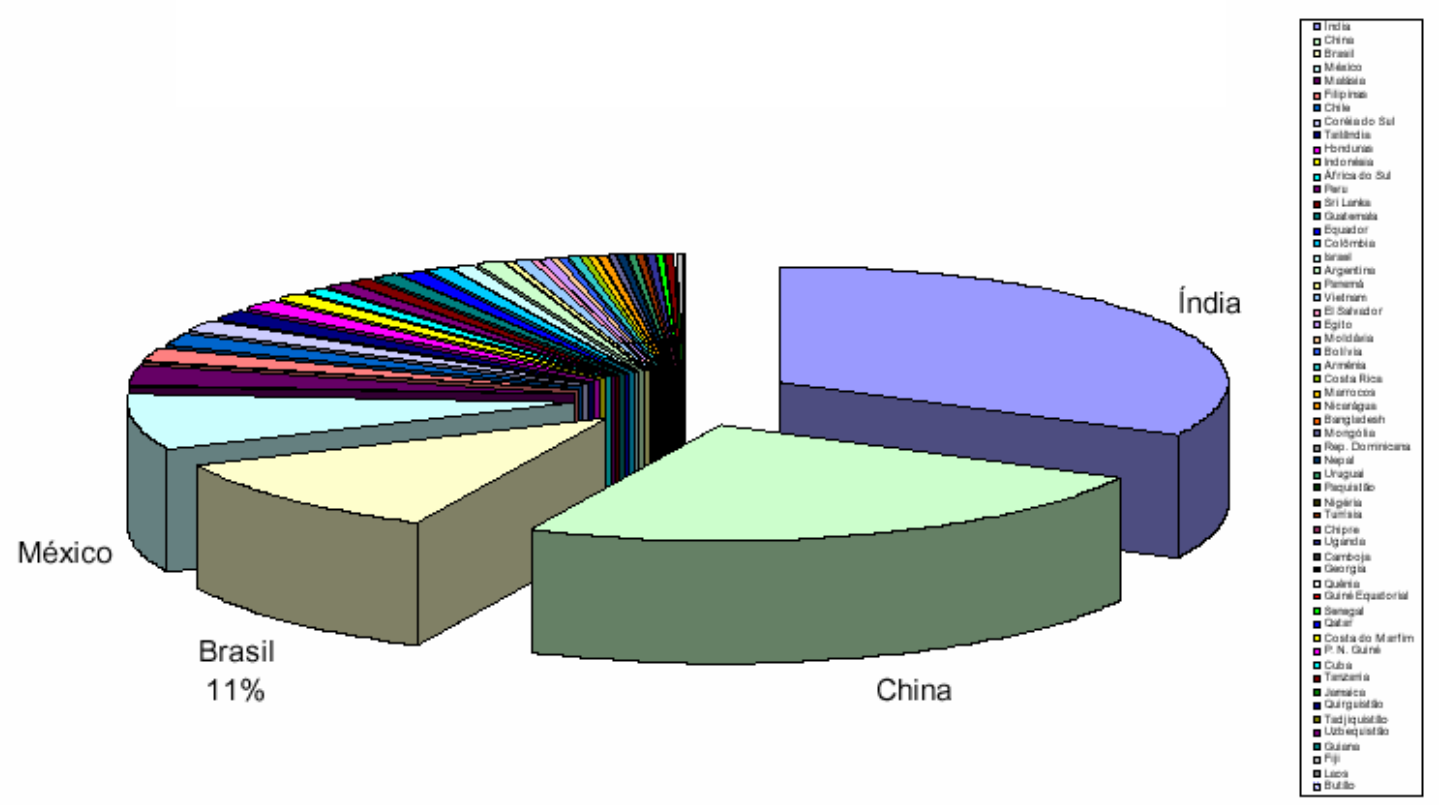

Fonte: BRASIL. Ministério da Ciência e Tecnologia. Status atual das atividades de projeto no âmbito do Mecanismo de Desenvolvimento Limpo (MDL) no Brasil e no mundo. Documento publicado pelo Ministério da Ciência e Tecnologia. p. 4. Disponível em: http://www.mct.gov.br/index.php/content/view/30317.html Acessado em 07/05/2007

A partir do número de projetos de MDL, calcula-se as reduções de emissões projetadas, e o Brasil ocupa a terceira posição, sendo responsável pela redução de 198 milhões de toneladas de $\mathrm{CO}_{2} \mathrm{e}$ para o primeiro período de obtenção de créditos, conforme gráficos abaixo: 


\section{Gráfico 6: Reduções de Emissões de $\mathrm{CO}^{\mathrm{e} e}$ para o primeiro período de obtenção de crédito}

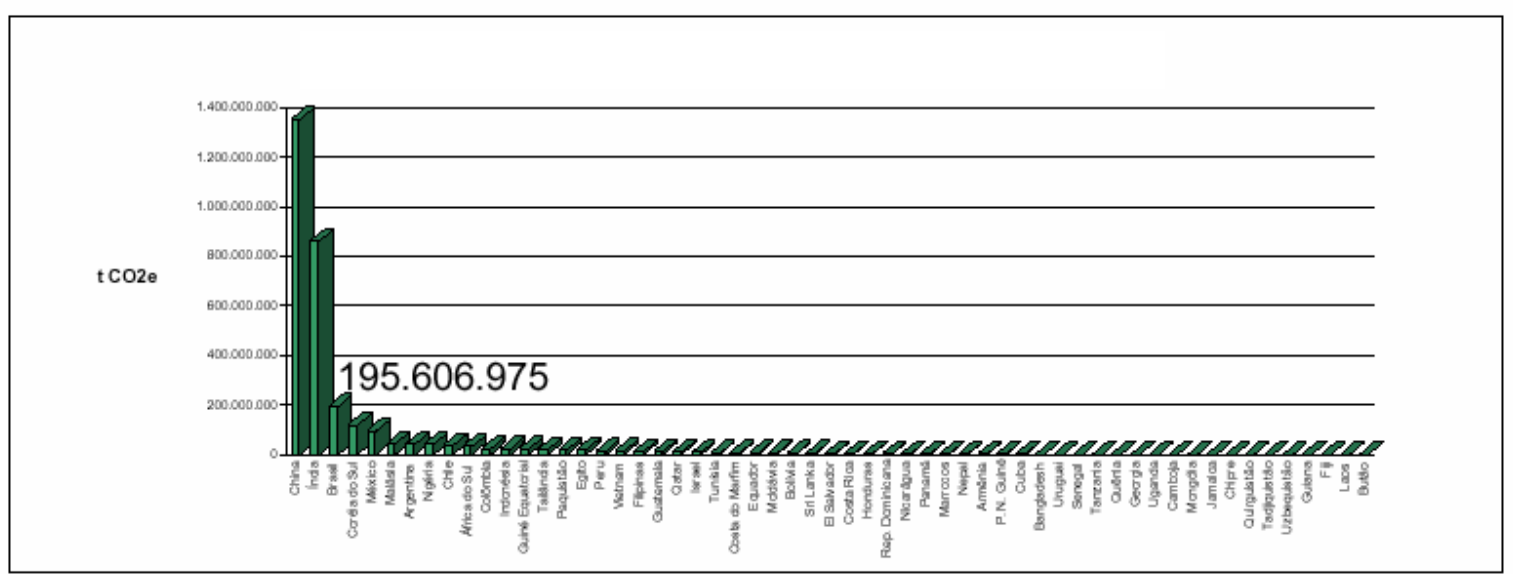

Fonte: BRASIL. Ministério da Ciência e Tecnologia. Status atual das atividades de projeto no âmbito do Mecanismo de Desenvolvimento Limpo (MDL) no Brasil e no mundo. Documento publicado pelo Ministério da Ciência e Tecnologia. p. 4. Disponível em: http://www.mct.gov.br/index.php/content/view/30317.html Acessado em 07/05/2007

\section{Gráfico 7: Reduções de Emissões para o Primeiro Período de Obtenção de Crédito (3.116 milhões de t CO2eq)}
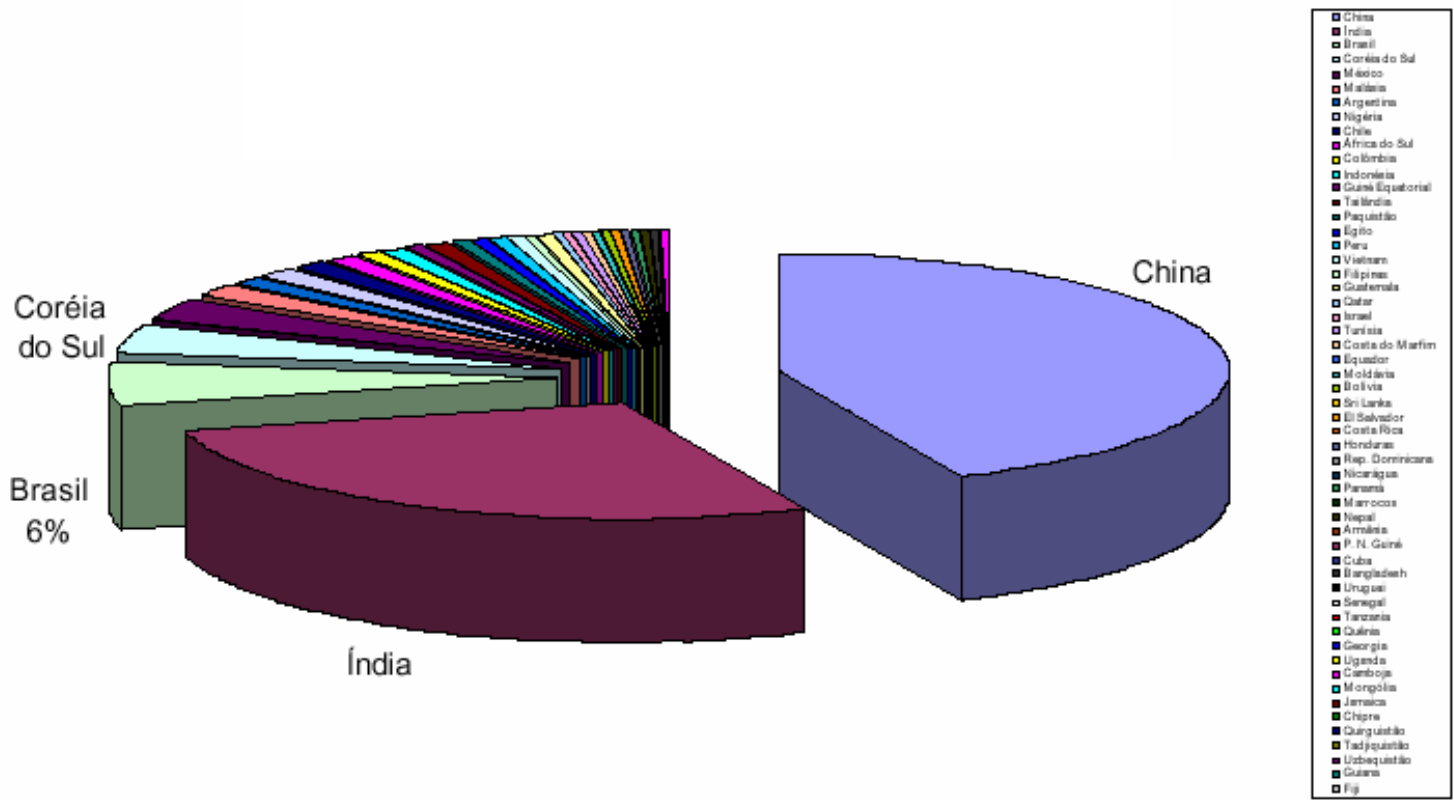

Fonte: BRASIL. Ministério da Ciência e Tecnologia. Status atual das atividades de projeto no âmbito do Mecanismo de Desenvolvimento Limpo (MDL) no Brasil e no mundo. Documento publicado pelo Ministério da Ciência e Tecnologia. p. 5. Disponível em: http://www.mct.gov.br/index.php/content/view/30317.html Acessado em 07/05/2007 
No Brasil, a maior parte dos projetos de MDL estão sendo desenvolvidos no setor energético, destacando-se a utilização da biomassa, conforme pode ser observado no gráfico abaixo:

\section{Gráfico 8: Número de projetos brasileiros por escopo setorial}

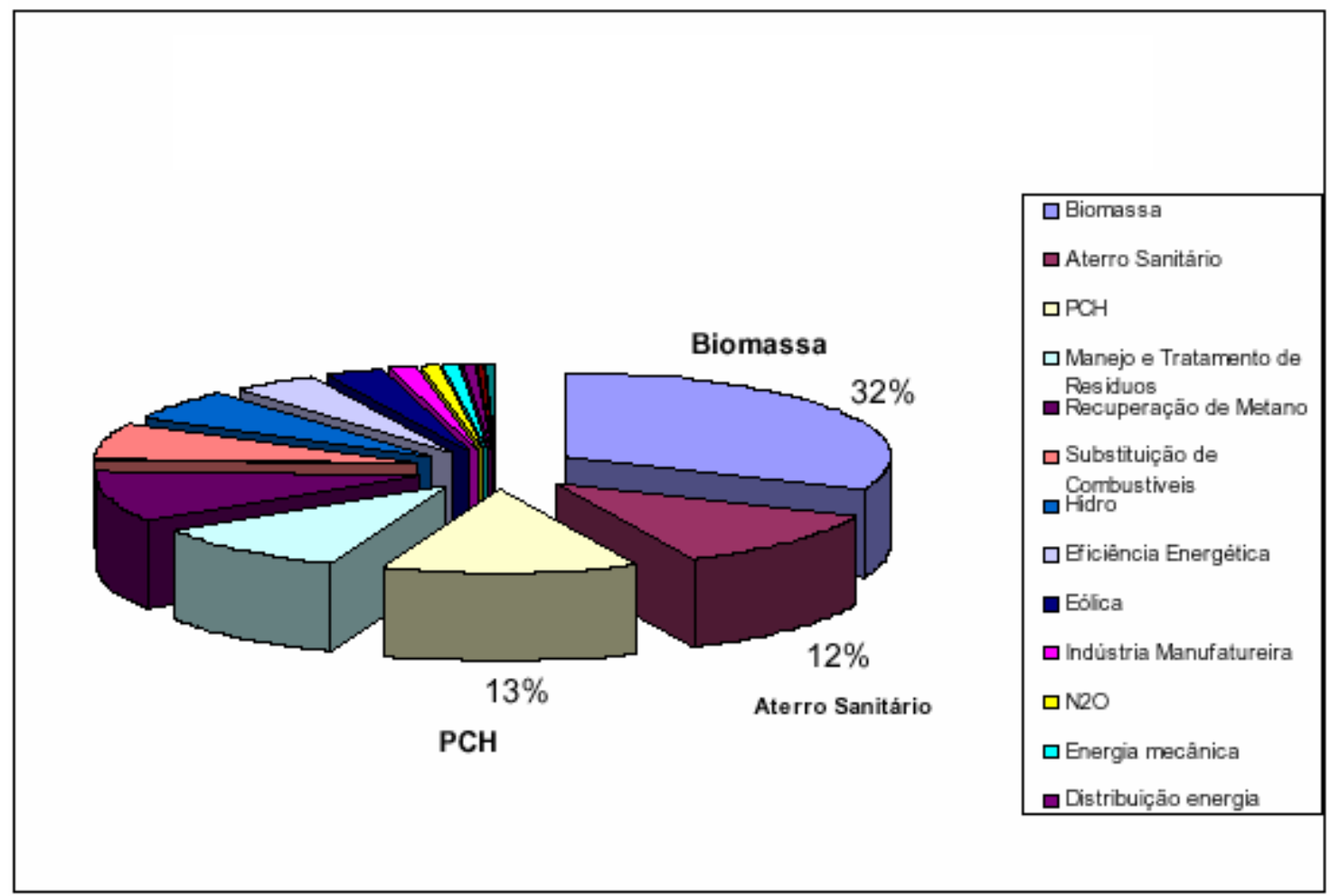

Fonte: BRASIL. Ministério da Ciência e Tecnologia. Status atual das atividades de projeto no âmbito do Mecanismo de Desenvolvimento Limpo (MDL) no Brasil e no mundo. Documento publicado pelo Ministério da Ciência e Tecnologia. p. 7. Disponível em: http://www.mct.gov.br/index.php/content/view/30317.html Acessado em 07/05/2007

\subsection{O Mercado de Carbono}

O Protocolo de Kyoto, como dito anteriormente, possibilitou a abertura de um mercado de créditos de carbono, ou seja, a criação um valor transacionável para as reduções dos GEE passível de ser comercializado na bolsa de valores. Segundo a definição do Banco Mundial, as transações de carbono: 
"(...) são definidas por contratos de compra por meio dos quais uma parte paga outra em retorno pelas reduções de emissões de GEE ou pelo direito de emitir uma quantidade de GEE, que o comprador pode usar para atingir seus objetivos de conformidade - ou cidadania corporativa - visà-vis a mitigação das mudanças climáticas. O pagamento é feito usando uma ou mais das seguintes formas: dinheiro, equidade, débito, débito convertido ou autorização, ou algum outro tipo de contribuição como por exemplo fornecendo tecnologias para o abatimento das emissões". ${ }^{60}$ (tradução da autora)

Antes da entrada em vigor do Protocolo de Kyoto, algumas iniciativas, como dito anteriormente, já haviam criado mercados para a comercialização dos futuros CERs. Entre eles destacamos: Emissions Trading Scheme, do Reino Unido, Chicago Climate Exchange, Prototype Carbon Fund do Banco Mundial. Alguns desses mercados têm regras próprias e não necessariamente comercializam créditos de carbono advindos de projetos desenvolvidos segundo as regras do Protocolo de Kyoto, como é o caso da Chicago Climate Exchange.

Dessa forma, como nosso objeto de estudo é resultado da aplicação do MDL, vamos nos ater a reportar com maiores detalhes os números do mercado fomentado pelos projetos sob as regras deste mecanismo.

Segundo dados do Banco Mundial de 2002 a 2006 cerca de $920 \mathrm{MtCO}_{2} \mathrm{e}$ provenientes de projetos de MDL foram comercializados. Só em 2006 os projetos de MDL comercializaram $450 \mathrm{MtCO}_{2} \mathrm{e}$, o que representa a movimentação de cerca de US\$ 4 bilhões, um aumento de 32\% no volume negociado em relação a 2005.

A tabela 7 abaixo indica os volumes e valores comercializados em 2005 e 2006 pelos projetos de MDL (MDL primário: comercialização entre o proprietário original do CER e o comprador; MDL secundário: comercialização na qual o vendedor dos CERs não é o proprietário original) e de Jl.

\footnotetext{
${ }^{60}$ Carbon transactions are defined as purchase contracts whereby one party pays another party in return for GHG emissions reductions or for the right to release a given amount of GHG emissions, that the buyer can use to meet its compliance - or corporate citizenship - objectives vis-à-vis climate change mitigation. Payment is made using one or more of the following forms: cash, equity, debt, convertible debt or warrant, or in-kind contributions such as providing technologies to abate GHG emissions. In: UNITED STATES. The World Bank. State and Trends of the Carbon Market 2007. Washington, D.C. - May 2007. p 8.
} 
Tabela 7: Volumes e valores anuais (2005-2006)

\begin{tabular}{|c|c|c|c|c|}
\hline & \multicolumn{2}{|c|}{2005} & \multicolumn{2}{|c|}{2006} \\
\hline & $\begin{array}{c}\text { Volume } \\
\left(\mathrm{MtCO}_{2} \mathrm{e}\right)\end{array}$ & $\begin{array}{c}\text { Value } \\
\text { (MUSS) }\end{array}$ & $\begin{array}{c}\text { Volume } \\
\left(\mathrm{MtCO}_{2} \mathrm{e}\right)\end{array}$ & $\begin{array}{l}\text { Value } \\
\text { (MUSS) }\end{array}$ \\
\hline $\begin{array}{l}\text { Compliance } \\
\text { of which }\end{array}$ & 382 & 2,894 & 508 & 5,477 \\
\hline Primary CDM & 341 & 2,417 & 450 & 4,813 \\
\hline $\begin{array}{r}\text { Secondary } \\
\text { CDM }\end{array}$ & 10 & 221 & 25 & 444 \\
\hline JI & 11 & 68 & 16 & 141 \\
\hline other & 20 & 187 & 17 & 79 \\
\hline $\begin{array}{r}\text { Voluntary } \\
\text { market }\end{array}$ & 6 & 44 & $10+$ & 100 \\
\hline TOTAL & 388 & 2,937 & 518 & $\mathbf{5 , 5 7 7}$ \\
\hline
\end{tabular}

Fonte: UNITED STATES. The World Bank. State and Trends of the Carbon Market 2007. Washington, D.C. - May 2007. p 20.

Os preços dos CERs, em 2006, ficaram em torno de US\$10,90 por $\mathrm{tCO}_{2} \mathrm{e}$, representando um aumento de $52 \%$ em relação aos valores de 2005 , que eram de US\$ 8,70.

Os principais compradores do mercado de projetos de MDL em 2006 foram os países europeus, com $86 \%$ dos volumes das transações, conforme pode ser observado no gráfico 9 abaixo. E dentre eles o Reino Unido é o maior responsável pelo volume comercializado, sendo responsável por $50 \%$ das transações, seguido pela Itália com 7\% e Espanha com cerca de 6-7\%. 


\section{Gráfico 9: Compradores MDL \& JI}

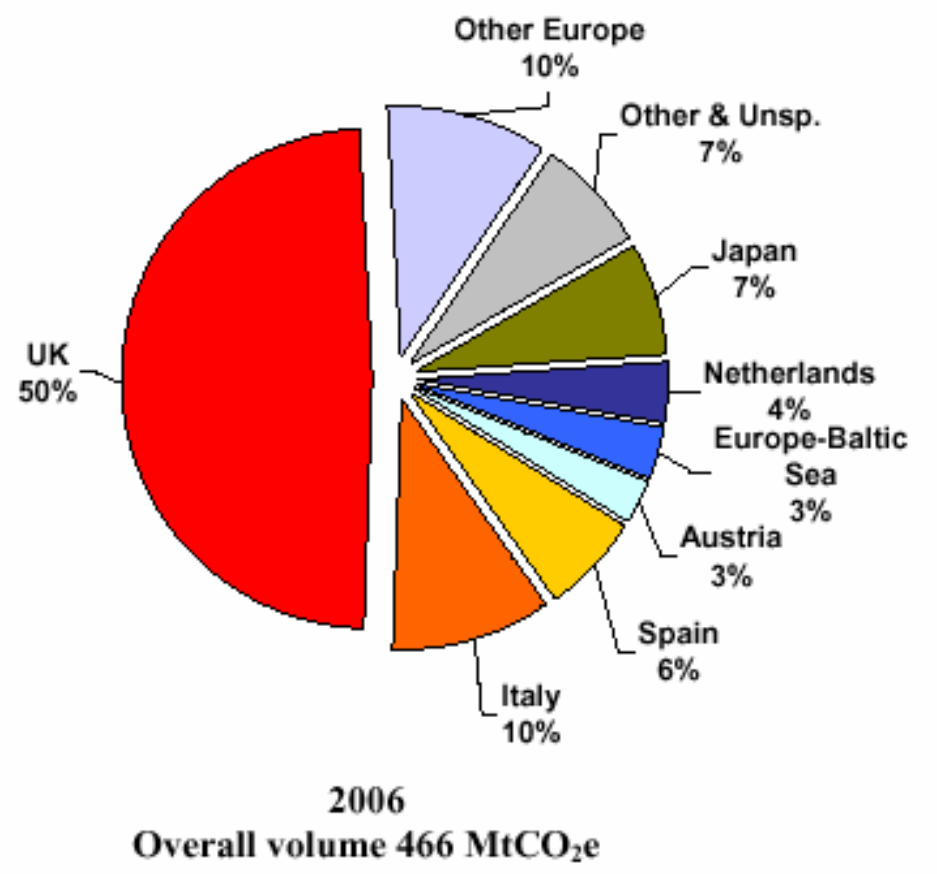

Fonte: UNITED STATES. The World Bank. State and Trends of the Carbon Market 2007. Washington, D.C. - May 2007. p 22.

O setor privado europeu foi o principal comprador de CER em 2006, sendo responsável por cerca de 90\% das transações.

O Brasil ocupa a terceira posição mundial em termos de redução de emissões projetadas, sendo responsável pela redução de $195 \mathrm{MtCO}_{2} \mathrm{e}$, para o primeiro período de obtenção de crédito. Considerando que o valor da redução de 01 tonelada de $\mathrm{MtCO}_{2} \mathrm{e}$ fosse mantido em US\$10,90, o volume comercializado pelo Brasil seria de US\$2.125.500.000 no período. Dessa forma, podemos considerar que o mercado de carbono é um potencial captador de recursos que poderão contribuir para o desenvolvimento sustentável.

O primeiro projeto de MDL registrado e validado em âmbito mundial pelo Protocolo de Kyoto é o brasileiro NovaGerar, desenvolvido na cidade de Nova Iguaçu no Rio de Janeiro. O projeto envolve a recuperação de um antigo lixão localizado em Marambaia e a construção de um aterro sanitário em Adrianópolis, com o intuito de aproveitar o biogás e reduzir as emissões de metano geradas pela decomposição dos resíduos depositados no aterro. No capítulo 4 
apresentaremos uma caracterização do município de Nova Iguaçu, uma breve discussão sobre os resíduos produzidos no Brasil e a concepção da Central de Tratamento de Resíduos de Nova Iguaçu, que possibilitou o desenvolvimento do projeto de MDL. 


\section{CAPÍTULO 4: O MUNICÍPIO DE NOVA IGUAÇU E A CENTRAL DE TRATAMENTO DE RESÍDUOS}

O capítulo 4 intitulado O município de Nova Iguaçu e a Central de Tratamento de Resíduos traz, em sua primeira parte, uma caracterização do município de Nova Iguaçu - Rio de Janeiro - no qual está instalado nosso objeto de estudo, o projeto Nova Gerar.

Uma breve abordagem da questão dos resíduos sólidos é apresentada na segunda seção deste capítulo. A problemática do lixo no Brasil é de suma importância quando tratamos do desenvolvimento sustentável, pois o não gerenciamento traz conseqüências para o meio ambiente e para a saúde dos seres humanos. Segundo o Censo do Instituto Brasileiro de Geografia e Estatística (IBGE) de 2000, no Brasil são produzidas diariamente 228.413 toneladas de resíduos urbanos, e somente $32,2 \%$ desse total são depositados em aterros sanitários ou controlados. A disposição em lixões perfaz um total de $63,6 \%$, acarretando problemas ambientais e fomentando uma prática degradante, que é a coleta de materiais recicláveis para a venda feita por catadores nos lixões de todo o país.

A Central de Tratamento de Resíduos de Nova Iguaçu (CTR Nova Iguaçu), diferentemente do que ocorre na maior parte do país, é um aterro sanitário licenciado pela agência estadual de controle ambiental (FEEMA), para operar no estado do Rio de Janeiro. A terceira parte deste capítulo apresentará o histórico da construção do aterro, bem como sua infra-estrutura.

A instalação e operação da CTR Nova Iguaçu possibilitou o desenvolvimento do NovaGerar. 


\subsection{Caracterização do Município de Nova Iguaçu $u^{61}$}

O Município de Nova Iguaçu está situado na Região Metropolitana do Rio de Janeiro (RMRJ), a 29,6 Km da capital do Estado. Limita-se com Miguel Pereira (ao norte), Duque de Caxias (nordeste), Japeri (noroeste), Rio de Janeiro (sul), Mesquita (sudeste), Seropédica (sudoeste). Belford Roxo (leste) e Queimados (oeste). Segundo a estimativa do Instituto Brasileiro de Geografia e Estatística IBGE para o ano de 2000, a população de Nova Iguaçu em 2006 é de 830.902 habitantes para um território de $524 \mathrm{Km}^{2}$, se constituindo no quarto município da RMRJ em tamanho da população e primeiro em extensão, tendo uma densidade de 1.585 habitantes por $\mathrm{Km}^{2}$. Dos $524 \mathrm{Km}^{2}$ de extensão, 67\% são áreas de proteção ambiental.

Em 1997, o município de Nova Iguaçu passou a denominar-se Cidade de Nova Iguaçu, pela Lei Complementar $n^{\circ} 006$, e foi dividido administrativamente em nove URG's (Unidades Regionais de Governo) que englobam 69 bairros.

A formação da cidade ocorre de forma bastante similar às demais da região da Baixada Fluminense, a partir do processo migratório tanto de outros estados brasileiros, especificamente os da região nordeste, como da migração intermunicipal a partir dos anos 90.

Assim, entre 1950 e 1980, um amplo processo migratório para a Baixada Fluminense proveniente, principalmente, do município do Rio de Janeiro e do nordeste brasileiro, articulado à omissão e ao descaso do poder público, promoveram uma ocupação acelerada e adensamento populacional em áreas desprovidas de infra-estrutura urbana. Neste período, a população de Nova Iguaçu cresceu cerca de 650\% em 30 anos, passando de 145.649 habitantes em 1950, para mais de um milhão de habitantes (1.094.789) em 1980.

Esse processo foi impulsionado pelo modelo de industrialização brasileira, concentrado em cidades da região sudeste do país, e pela ausência de uma política de reforma agrária e de mecanismos que garantissem os direitos trabalhistas no campo. A maior parte dos trabalhadores da RMRJ foi excluída do acesso ao mercado formal da terra urbana em função, entre outros fatores, de um

${ }^{61}$ Os dados para a caracterização do município de Nova Iguaçu foram retirados do site da prefeitura: www.novaiguacu.ri.gov.br, acessado em 28/05/2007. 
mercado de trabalho com alta incidência de informalidade e de ocupações de baixa qualificação. A solução adotada pelos pobres - desprovidos de direitos e deixados pelo Estado à própria sorte - foi a de ocupar os morros nas áreas centrais do Rio de Janeiro ou as regiões periféricas, como Nova Iguaçu. Distantes do local de trabalho, as regiões metropolitanas geralmente são áreas desprovidas de infra-estrutura e situadas em áreas de risco ambiental - expostas a alagamentos, desabamentos e alto grau de poluição hídrica e atmosférica obtidas por meio da posse ou da compra de lotes irregulares. Do total de domicílios do município, 81\% têm acesso à rede de abastecimento de água, 88\% têm coleta de lixo e apenas 52\% possuem esgoto sanitário ligado à rede coletora, $47 \%$ tem os logradouros pavimentados e $88 \%$ têm acesso à iluminação pública.

Entretanto, Nova Iguaçu não é formada somente por população de baixa renda e representa uma importante centralidade econômica na Baixada Fluminense. É o segundo maior Produto Interno Bruto $(R \$ 3.816 .154,00)$ e o segundo maior orçamento $(\mathrm{R} \$ 581.996 .817,05)$ da Baixada, concentrando significativa parcela das atividades de comércio e indústria.

A centralidade econômica, no entanto, não é embasada em um modelo de desenvolvimento sustentável, democrático e includente. A exemplo de como essa desigualdade se expressa territorialmente, o centro de Nova Iguaçu se constitui em uma "ilha" de população de renda mais alta, onde $10 \%$ dos residentes ocupados são empregadores e 19\% profissionais de nível superior (Censo IBGE, 2000), enquanto sua grande periferia o coloca como o segundo maior município da RMRJ em número de pessoas vivendo na extrema pobreza e em número de desempregados. Esse contexto de ausência de cidadania e desigualdade se reflete num quadro extremo de violência que pode ser avaliado pela taxa de 74,7 homicídios por 100.000 habitantes.

Nosso objeto de estudo, o projeto NovaGerar, está localizado na cidade de Nova Iguaçu, na Central de Tratamento de Resíduos, a qual discutiremos adiante. 


\section{LOCALIZACQÃO DA CTR - NOVA IGUAÇU}

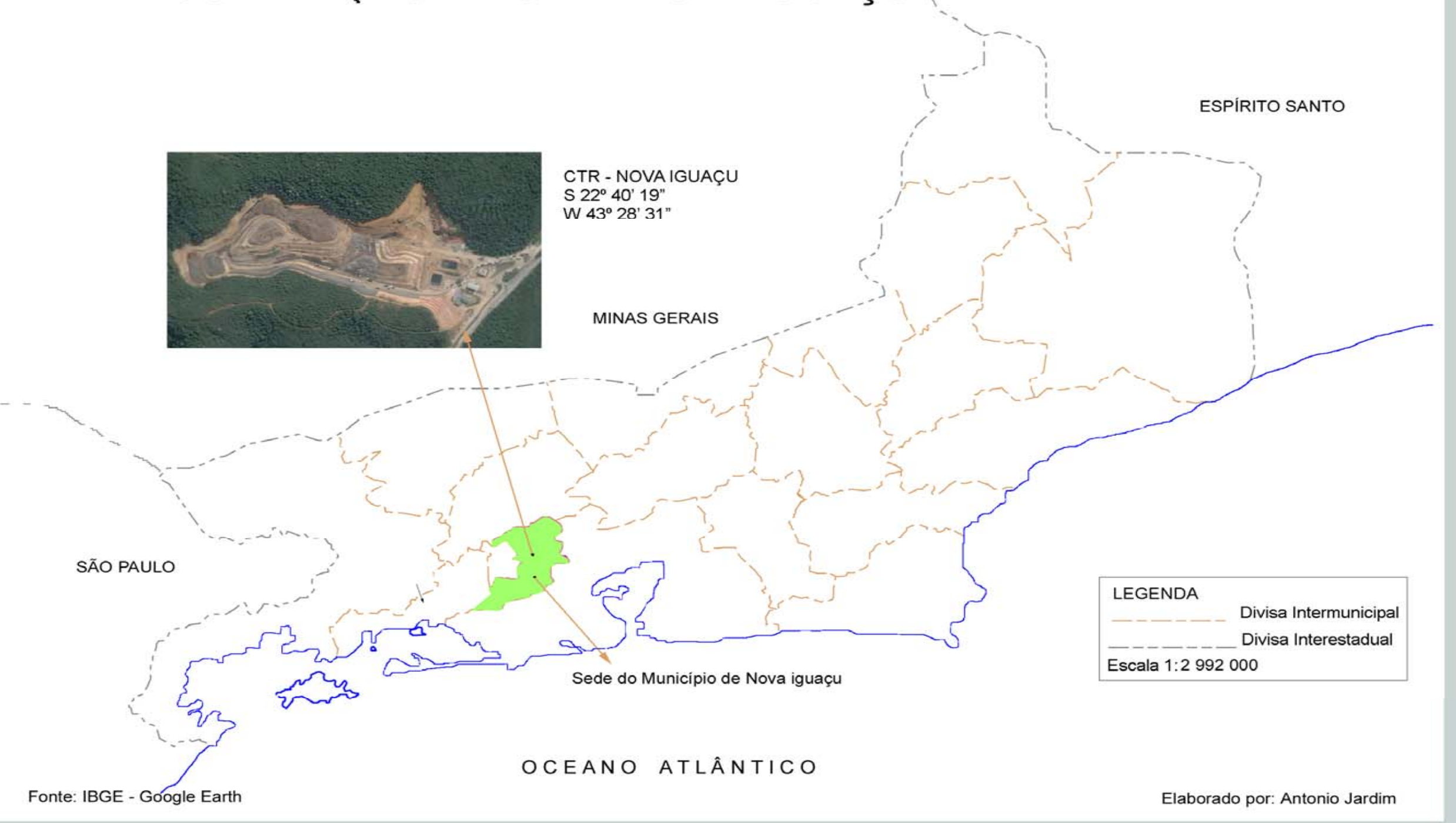




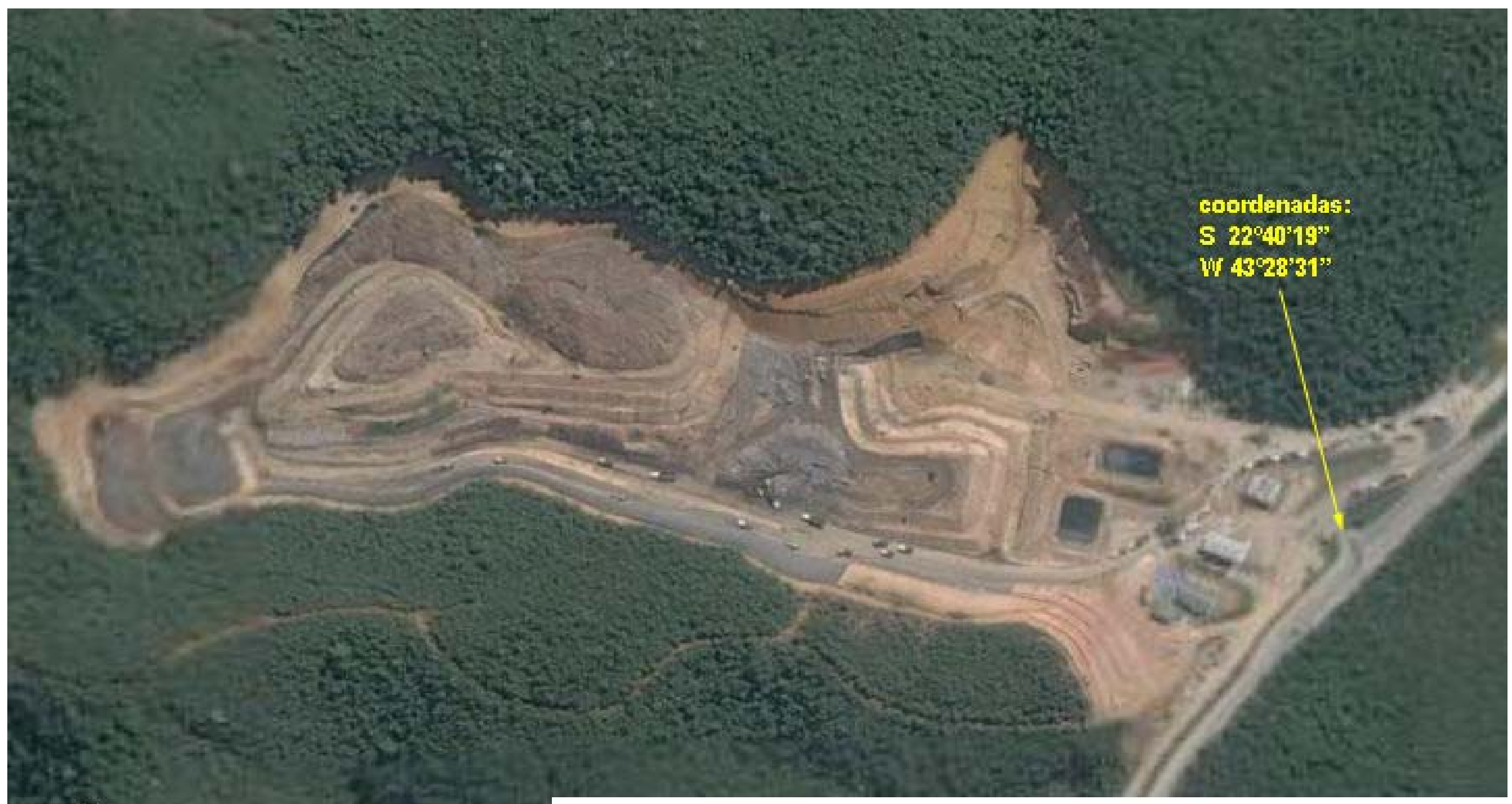

Local: CTR Nova Iguaçu

Elaborado por Antonio Jardim
Fonte: Google Earth Digital Globe 2007

Escala $1: 2.830$ 


\subsection{Resíduos Sólidos}

A Associação Brasileira de Normas Técnicas - ABNT, define resíduos sólidos como os

"(...) restos das atividades humanas, considerados pelos geradores como inúteis, indesejáveis ou descartáveis, podendo-se apresentar no estado sólido, semi-sólido ou líquido, desde que não seja passível de tratamento convencional. ${ }^{.62}$

A problemática dos resíduos sólidos é complexa e tem reflexos no ambiente e nas condições sanitárias da população. Segundo RIBEIRO e GÜNTHER,

"A produção crescente de resíduos sólidos tem sido agudizada por outros fatores mais modernos: novas tecnologias de produtos e materiais descartáveis, incorporados no consumo de bens e produtos; incentivo ao consumo como fator de diferenciação socioeconômica; falta de políticas que incentivem a redução da geração e carência de informação e consciência ambiental da população."63

Os resíduos produzidos podem ser classificados de diversas formas, como por exemplo por sua natureza física (seco/molhado); por sua composição química (orgânico/inorgânico); pelos riscos potenciais ao meio ambiente e por sua origem.

Quanto aos riscos potenciais ao meio ambiente, podem ser classificados, de acordo com a NBR 10.004 da Associação Brasileira de Normas Técnicas (ABNT), como classes I, II ou III.

"Classe I ou perigosos: São aqueles que, em função de suas características intrínsecas de inflamabilidade, corrosividade, reatividade,toxicidade ou patogenicidade, apresentam riscos à saúde pública através do aumento da mortalidade ou da morbidade, ou ainda

\footnotetext{
${ }^{62}$ MONTEIRO, J.H.P. [et al]. Manual de Gerenciamento Integrado de resíduos sólidos. Rio de Janeiro:IBAM,2001. p. 25.

${ }^{63}$ RIBEIRO,H. e GÜNTHER, W. Urbanização, Modelo de Desenvolvimento e a Problemática dos Resíduos Sólidos Urbanos. In: Patrimônio Ambiental Brasileiro, Edusp, São Paulo, 2003. p. 473.
} 
provocam efeitos adversos ao meio ambiente quando manuseados ou dispostos de forma inadequada.

Classe II ou não-inertes: São os resíduos que podem apresentar características de combustibilidade, biodegradabilidade ou solubilidade, com possibilidade de acarretar riscos à saúde ou ao meio ambiente, não se enquadrando nas classificações de resíduos Classe I Perigosos - ou Classe III -Inertes.

Classe III ou inertes: São aqueles que,por suas características intrínsecas,não oferecem riscos à saúde e ao meio ambiente, e que, quando amostrados de forma representativa, segundo a norma NBR 10.007,e submetidos a um contato estático ou dinâmico com água destilada ou deionizada,a temperatura ambiente,conforme teste de solubilização segundo a norma NBR 10.006,não tiverem nenhum de seus constituintes solubilizados a concentrações superiores aos padrões de potabilidade da água,conforme listagem $\mathrm{n}$ ०8 (Anexo $\mathrm{H}$ da NBR 10.004), excetuando-se os padrões de aspecto, cor, turbidez e sabor." ${ }^{64}$

Quanto à origem, destacamos:

"Lixo doméstico ou residencial: São os resíduos gerados nas atividades diárias em casas, apartamentos, condomínios e demais edificações residenciais.

Lixo comercial: São os resíduos gerados em estabelecimentos comerciais, cujas características dependem da atividade ali desenvolvida.

Lixo público: São os resíduos presentes nos logradouros públicos, em geral resultantes da natureza, tais como folhas, galhadas, poeira, terra e areia, e também aqueles descartados irregular e indevidamente pela população, como entulho, bens considerados inservíveis, papéis, restos de embalagens e alimentos.

Lixo domiciliar especial: Grupo que compreende os entulhos de obras, pilhas e baterias, lâmpadas fluorescentes e pneus. Os entulhos de obra, também conhecidos como resíduos da construção civil, só estão enquadrados nesta categoria por causa da grande quantidade de sua

${ }^{64}$ MONTEIRO, J.H.P. [et al]. Manual de Gerenciamento Integrado de resíduos sólidos. Rio de Janeiro:IBAM,2001. p. 25. 
geração e pela importância que sua recuperação e reciclagem vem assumindo no cenário nacional.

Entulho de obras: Em termos de composição, os resíduos da construção civil são uma mistura de materiais inertes, tais como concreto, argamassa, madeira, plásticos, papelão, vidros, metais, cerâmica e terra.

Lixo industrial: São os resíduos gerados pelas atividades industriais. São resíduos muito variados que apresentam características diversificadas, pois estas dependem do tipo de produto manufaturado. Devem, portanto, ser estudados caso a caso. Adota-se a NBR 10.004 da ABNT para se classificar os resíduos industriais: Classe I (Perigosos), Classe II (Não-Inertes) e Classe III (Inertes).

Lixo radioativo: Assim considerados os resíduos que emitem radiações acima dos limites permitidos pelas normas ambientais. No Brasil, o manuseio, acondicionamento e disposição final do lixo radioativo está a cargo da Comissão Nacional de Energia Nuclear - CNEN.

Lixo de portos, aeroportos e terminais rodoviários: Resíduos gerados tanto nos terminais, como dentro dos navios, aviões e veículos de transporte. Os resíduos dos portos e aeroportos são decorrentes do consumo de passageiros em veículos e aeronaves e sua periculosidade está no risco de transmissão de doenças já erradicadas no país. A transmissão também pode se dar através de cargas eventualmente contaminadas, tais como animais, carnes e plantas.

Lixo agrícola: Formado basicamente pelos restos de embalagens impregnados com pesticidas e fertilizantes químicos, utilizados na agricultura, que são perigosos. Portanto o manuseio destes resíduos segue as mesmas rotinas e se utiliza dos mesmos recipientes e processos empregados para os resíduos industriais Classe I. A falta de fiscalização e de penalidades mais rigorosas para o manuseio inadequado destes resíduos faz com que sejam misturados aos resíduos comuns e dispostos nos vazadouros das municipalidades, ou - o que é pior - sejam queimados nas fazendas e sítios mais afastados, gerando gases tóxicos.

Resíduos de serviços de saúde: Compreendendo todos os resíduos gerados nas instituições destinadas à preservação da saúde da população." 65

${ }^{65}$ MONTEIRO, J.H.P. [et al]. Manual de Gerenciamento Integrado de resíduos sólidos. Rio de Janeiro:IBAM,2001. p. 27-32. 
De acordo com a Política Nacional de Meio ambiente - Lei 6938/1981, o poder público municipal, no Brasil, é o responsável pela chamada Limpeza Urbana, que inclui a varrição, limpeza das ruas, coleta dos resíduos sólidos domiciliares, transporte, tratamento e disposição final. As indústrias, comércio e prestadores de serviços, são responsáveis pelos resíduos gerados em suas atividades, desde a geração até a disposição final.

A disposição final dos resíduos pode ser feita nos seguintes locais, conforme descrito no Manual de Gerenciamento Integrado do Instituto de Pesquisas Tecnológicas (IPT) e do Compromisso Empresarial para Reciclagem (CEMPRE):

"Lixão: é uma forma inadequada de disposição final de resíduos sólidos municipais, que se caracteriza pela simples descarga sobre o solo, sem medidas de proteção ao meio ambiente ou à saúde pública. Os resíduos assim lançados acarretam problemas à saúde pública, como proliferação de vetores de doenças (moscas, mosquitos, baratas, ratos, etc.), geração de maus odores e, principalmente, poluição do solo e das águas subterrânea e superficial, pela infiltração do chorume.

Aterro Controlado: é uma forma de disposição de resíduos sólidos municipais no solo, sem causar danos ou riscos à saúde pública e à sua segurança, minimizando os impactos ambientais. Esse método utiliza alguns princípios de engenharia para confinar os resíduos sólidos, cobrindo-os com uma camada de material inerte na conclusão de cada jornada de trabalho. Esta forma de disposição produz poluição, porém localizada, pois, similarmente ao aterro sanitário, a área de disposição é miniizada. Geralmente, não dispõe de impermeabilização de base (comprometendo a qualidade das águas subterrâneas), nem de sistemas de tratamento de percolado (termo empregado para caracterizar a mistura entre o chorume - líquido preto produzido pela decomposição do lixo - e a água de chuva que percola o aterro) ou sistemas de captação, drenagem e canalização do gás gerado. Este método é preferível ao lixão, mas devido aos problemas ambientais que causa e aos seus custos de operação, é de qualidade bastante inferior ao aterro sanitário. 
Aterro Sanitário: é um processo utilizado para a disposição de resíduos sólidos no solo, particularmente lixo domiciliar que, fundamentado em critérios de engenharia e normas operacionais específicas, permite um confinamento seguro em termos de controle de poluição ambiental e proteção à saúde pública." ${ }^{\prime 66}$

A análise das soluções citadas acima para disposição final do lixo no solo permite-nos concluir que o meio mais adequado é a utilização do aterro sanitário. Os aterros sanitários são construídos seguindo critérios de engenharia e normas operacionais específicas, mitigando a poluição ambiental e garantindo a proteção da saúde pública. Dispõem de camadas de impermeabilização de base (para impedir a contaminação da água subterrânea), usualmente uma primeira camada de um metro $(1 \mathrm{~m}$ ) de solo compactado e uma segunda camada de geomembrana de PEAD (polietileno de alta densidade), além de sistema de drenagem e tratamento de chorume (percolado) e de gás. O Aterro Industrial é uma variante do aterro sanitário, onde o dimensionamento é específico para resíduos originários de indústrias. Podem ser dimensionados de forma mais rigorosa para a disposição de resíduos perigosos (classe I de acordo com a NBR 10.004) ou praticamente da mesma forma que o aterro sanitário para o caso de resíduos classe II (não perigosos).

\subsubsection{Resíduos Sólidos no Brasil e no Rio de Janeiro}

Segundo a Pesquisa Nacional de Saneamento Básico (PNSB) do Censo IBGE de 2000, são coletadas 228.413 toneladas por dia de resíduos urbanos no Brasil. A estimativa de população efetuada pelo IBGE também para o ano de 2000 apresenta o número de 166.112.518 habitantes. Com estes números, calcula-se uma geração per capita de 1,39 kg de resíduo/habitante/dia.

A PNSB 2000 indica que dos 5.507 municípios brasileiros, 63,6\% utilizam lixões e 32,2\%, aterros adequados (13,8\% sanitários, 18,4\% aterros controlados), sendo que $5 \%$ não informaram para onde vão seus resíduos.

66 IPT/CEMPRE. Instituto de Pesquisas Tecnológicas; Compromisso Empresarial para Reciclagem. Lixo Municipal - Manual de Gerenciamento Integrado. $2^{\mathrm{a}}$ edição. Página \& Letras, 2000. p.251-252. 
Apesar destes números não serem nada satisfatórios quando consideramos que os resíduos não gerenciados de forma adequada resultam em poluição e prejuízo à saúde, de 1989 (data da última PNSB antes do Censo de 2000) para 2000 houve uma melhora relativa em sua destinação final, conforme pode ser observado na tabela abaixo:

Tabela 8: Quantidade de lixo coletado, em número absoluto e relativo, por tipo de destinação final - Brasil - 1989/2000

\begin{tabular}{|c|c|cc|c|c|}
\hline \multirow{2}{*}{ Ano } & \multicolumn{4}{|c|}{ Quantidade de lixo coletado, por tipo de destinação final } \\
\cline { 2 - 6 } & \multirow{2}{*}{ Total (t/dia) } & \multicolumn{2}{|c|}{ Adequada } & \multicolumn{2}{c|}{ Inadequada } \\
\cline { 3 - 6 } & & Total (t/dia) & Relativo (\%) & Total (t/dia) & Relativo (\%) \\
\hline 1989 & 96.287 & 27.754 & 28,8 & 68.533 & 71,2 \\
2000 & 228.413 & 92.487 & 40,5 & 135.926 & 59,5 \\
\hline
\end{tabular}

Fonte: Pesquisa nacional de saneamento básico 2000. Rio de Janeiro:IBGE, 2002. p.144

No estado do Rio de Janeiro, a PNSB 2000, indicou que são coletadas por dia 17.447, 2 toneladas de resíduos urbanos. A estimativa da população (IBGE, 2000) é de 13.933.756 habitantes, dessa forma, a geração de resíduos per capita é de 1,25 kg/habitante/dia. A pesquisa indica ainda, que do total de resíduos gerados, apenas 45,9\% tem destinação adequada.

A quantidade de resíduos urbanos gerada no estado do Rio de Janeiro corresponde a 7,6\% do total gerado por dia no Brasil.

Do total de resíduos produzidos no estado do Rio de Janeiro - 17.447,2 toneladas/dia - a região metropolitana (RMRJ), na qual encontra-se o município de Nova Iguaçu, é responsável por 13.429,4 toneladas. Na RMRJ existe somente 01 (um) aterro sanitário devidamente licenciado pelo órgão ambiental do estado FEEMA. Trata-se do aterro da Central de Tratamento de Resíduos de Nova Iguaçu, que discutiremos mais adiante.

A segunda opção para os resíduos urbanos, e a mais utilizada, é o Aterro Metropolitano de Gramacho. O aterro é controlado, não licenciado pela FEEMA e operado pela Companhia de Limpeza Urbana da Cidade do Rio de Janeiro (COMLURB). Está em atividade desde a década de 70 no município de Duque de Caxias e recebe cerca de 8.000 toneladas por dia da cidade do Rio de Janeiro, Duque de Caxias, São João de Meriti, Nilópolis, Queimados e Mesquita. 
O outro aterro em operação da COMLURB é o aterro de Bangu. É também um aterro controlado, não licenciado e que recebe aproximadamente 2.000 toneladas por dia de resíduos da Cidade do Rio Janeiro. Existe ainda o Aterro de Morro do Céu que recebe os resíduos urbanos de Niterói e o Aterro de Itaoca para os resíduos de São Gonçalo. Ambos os aterros são controlados, não licenciados, e recebem, juntos, em torno de 1.600 toneladas por dia de resíduos.

O somatório das destinações citadas chega num valor de 12.600 toneladas por dia. Como citado anteriormente, de acordo com o IBGE, a coleta de resíduos urbanos na região metropolitana do Rio de Janeiro é de 13.429,4 toneladas por dia. A diferença entre as 12.600 toneladas das destinações citadas e o número do IBGE é de aproximadamente 830 toneladas diárias. Esta diferença refere-se a destinação em lixões e aterros controlados de menor porte como o aterro Babi em Belford Roxo, aterro de Magé e outros.

\subsection{Central de Tratamento de Resíduos de Nova Iguaçu}

A Central de Tratamento de Resíduos de Nova Iguaçu teve seu início por meio da licitação pública da prefeitura de Nova Iguaçu através de sua empresa de Limpeza Urbana, EMLURB, para a concessão dos serviços de tratamento e disposição final dos resíduos sólidos domiciliares e públicos da cidade. A empresa vencedora da licitação, a concessionária, teria que projetar a Central de Tratamento de Resíduos (CTR), realizar os estudos ambientais, elaborar o projeto executivo, proceder o licenciamento ambiental, implantar, operar e monitorar a CTR por 20 anos e fazer o encerramento e recuperação ambiental do antigo lixão da cidade, o Lixão de Marambaia.

A remuneração básica para a concessionária seria:

- $\quad$ "Receber uma tarifa por tonelada de resíduos recebidos por mês da Prefeitura de Nova Iguaçu (valor definido na proposta comercial vencedora da licitação);

- Deste valor seria descontado percentual de $20 \%$ a título de franquia, pela propriedade do terreno ser da própria prefeitura e não da concessionária; 
- $\quad$ Outras receitas da CTR seriam permitidas e à Prefeitura de Nova Iguaçu seria direcionado percentual da Receita Bruta a título de outorga." 67

A empresa vencedora da licitação foi a S.A. Paulista, atuante no mercado da construção pesada, que ficou responsável por implantar e operar a CTR de Nova Iguaçu e recuperar o lixão de Marambaia.

A Central Integrada de Tratamento de Resíduos de Nova Iguaçu entrou em operação em 13 de fevereiro de 2003, após um processo de licenciamento ambiental de três anos, ocupando uma área de 1,2 milhão de metros quadrados. É totalmente licenciada: possui L.I. (Licença de Instalação) e L.O. (Licença de Operação) emitidas pela FEEMA (órgão estadual de controle ambiental), parecer favorável e autorização do IBAMA e Licença da Prefeitura de Nova Iguaçu, sendo:

- IBAMA - Federal - Parecer Favorável à implantação;

- IBAMA - Federal - Autorização para supressão de vegetação;

- DNPM - Departamento Nacional de Produção Mineral do Ministério de Minas e Energia - Certidão de não oposição;

- CECA - Comissão Estadual de Controle Ambiental - Deliberação Outorga da Licença de Instalação;

- FEEMA - Fundação Estadual de Controle Ambiental - Emissão da Licença de Instalação e da Licença de Operação;

- DRM - Departamento de Recursos Minerais - Secretaria de Estado de Energia, da Indústria Naval e do Petróleo do Estado do Rio de Janeiro Declaração de nada a opor;

- Ministério Público do Estado do Rio de Janeiro - Parecer favorável e assinatura do TAC - Termo de Ajustamento de Conduta de caráter preventivo;

- Prefeitura da Cidade de Nova Iguaçu - Licença emitida pela Secretaria de Urbanismo e Meio Ambiente.

${ }^{67}$ FELIPETTO, Adriana V. Montenegro. Avaliação de Concessionária de Tratamento de Resíduos com Opções Reais. Dissertação de Mestrado.Rio de Janeiro: Faculdades Ibmec, 2005. p.. 62. 
De acordo com as licenças, a Central pode receber resíduos urbanos, de grandes geradores e industriais classes II e III (não perigosos), de acordo com a NBR 10.004. A CTR, também pode de acordo com as licenças ambientais receber os resíduos ambulatoriais das indústrias e resíduos de estabelecimentos de saúde.

O contrato de concessão com a Prefeitura de Nova Iguaçu prevê o recebimento e tratamento dos resíduos domiciliares e públicos da cidade. É um contrato de longo prazo (20 anos) no qual a Prefeitura paga à concessionária uma tarifa por tonelada de resíduos que entram na unidade. A prefeitura é a responsável pela limpeza, coleta e transporte dos resíduos. Contratualmente, a obrigação da concessionária é tratar e dispor os resíduos encaminhados à CTR. Todos os veículos que entram na unidade são pesados e, no final do mês, a concessionária fatura o valor da tarifa multiplicada pela quantidade (em toneladas) de resíduos que entraram na unidade.

\subsubsection{A Estrutura da CTR Nova Iguaçu ${ }^{68}$}

A CTR Nova Iguaçu é composta por um Aterro Sanitário (para resíduos classes II e III), um Aterro Industrial, uma Unidade de Tratamento de Percolados (chorume), uma Unidade de Tratamento Térmico de Resíduos de Serviços de Saúde (ambulatoriais e hospitalares) e uma Unidade de Reciclagem de Entulho da Construção Civil.

${ }^{68}$ As informações para a elaboração deste item foram obtidas durante o trabalho de campo em julho de 2005. 
Figura 3: Central de Tratamento de Resíduos Nova Iguaçu

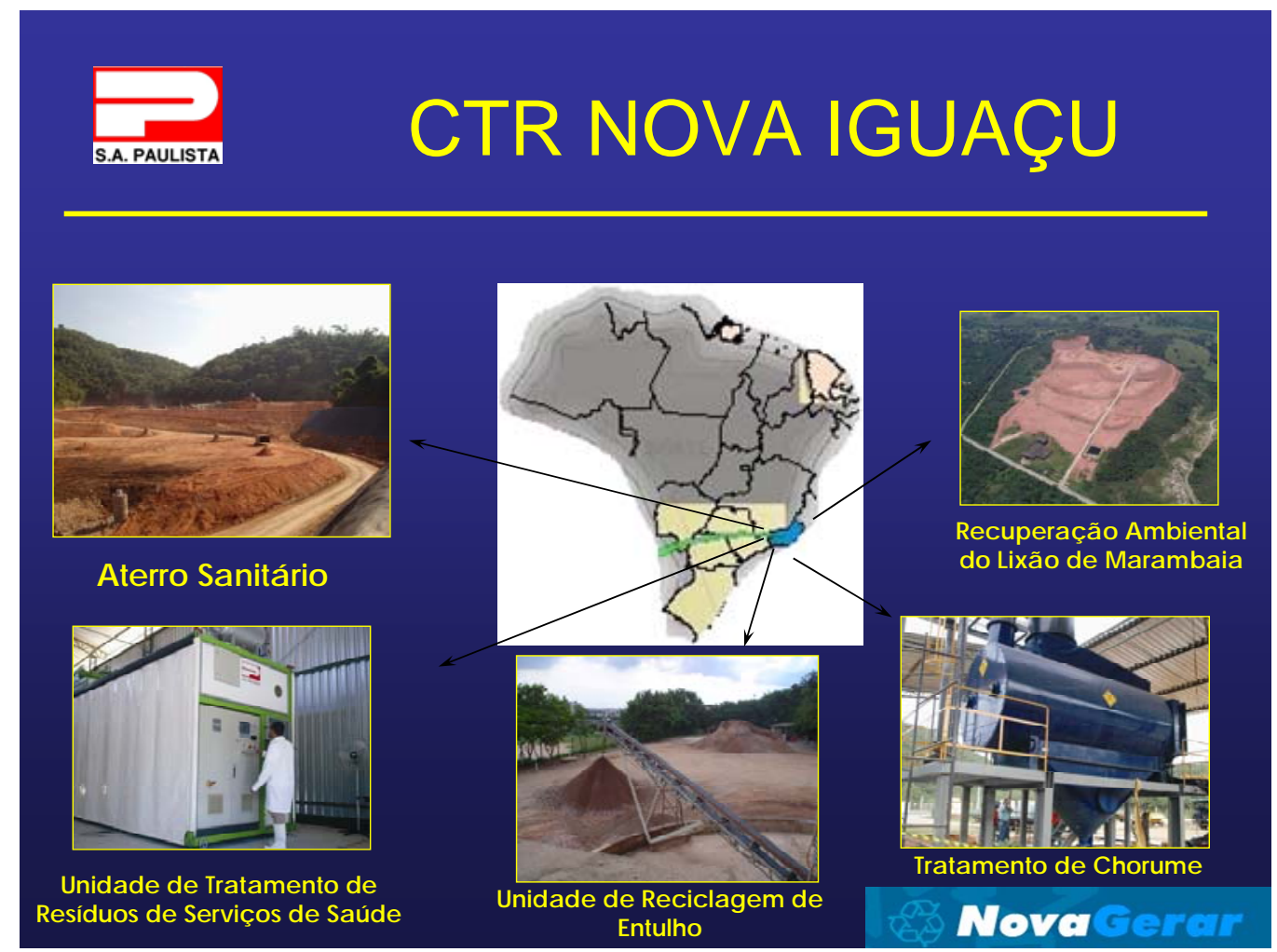

Fonte: CTR Nova Iguaçu, 2005.

\section{a) Aterro Sanitário e Industrial}

Para a total proteção do solo e água subterrânea tem-se uma impermeabilização de fundação composta por uma camada de 1,10 $\mathrm{m}$ de solo argiloso compactado com baixíssima permeabilidade protegida por uma manta de polietileno de alta densidade (PEAD) de 1,5 $\mathrm{mm}$ de espessura. 


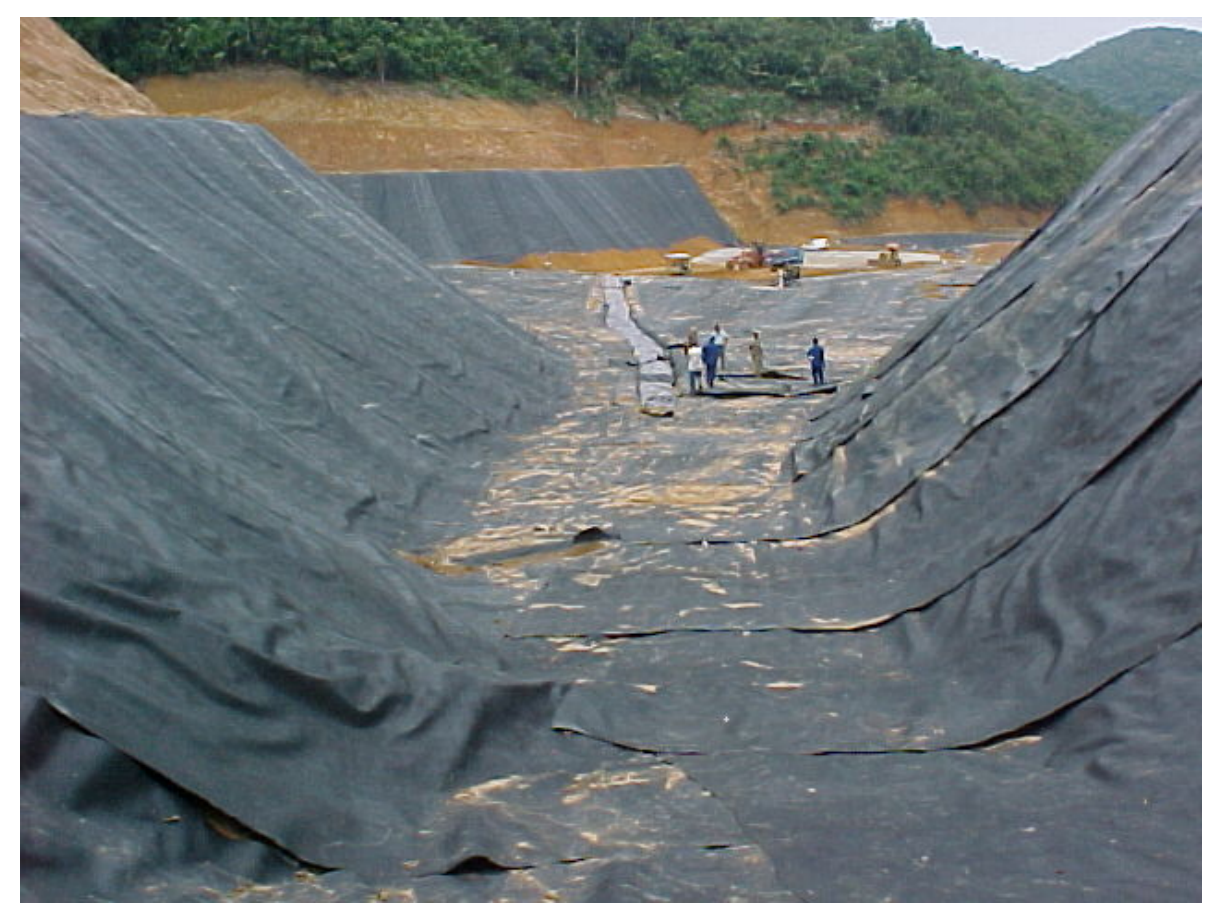

Figura 4: Manta de polietileno de alta densidade (PEAD) Fonte: CTR Nova Iguaçu (sem data)

O biogás gerado pela decomposição da matéria orgânica do lixo é drenado, canalizado e encaminhado para equipamentos específicos. Estes equipamentos específicos podem ser flares (equipamentos para queima eficiente e controlada) nos quais o metano é queimado e totalmente transformado em gás carbônico, ou podem ser conjunto de motores e geradores para geração de energia elétrica. A opção pela geração de energia elétrica somente será exercida caso o preço de venda da energia viabilize economicamente a geração. Em caso contrário, o gás será direcionado para o flare de queima controlada.

O aterro possui drenagem de águas pluviais para evitar a contaminação destas pelo chorume. Os taludes das células têm proteção vegetal para que não haja erosão, e todo o solo utilizado para cobertura do lixo é extraído do próprio local.

O aterro recebe atualmente em média 1.500 toneladas de lixo por dia. ${ }^{69}$

${ }^{69}$ Fonte: CTR Nova Iguaçu em julho/2007. 


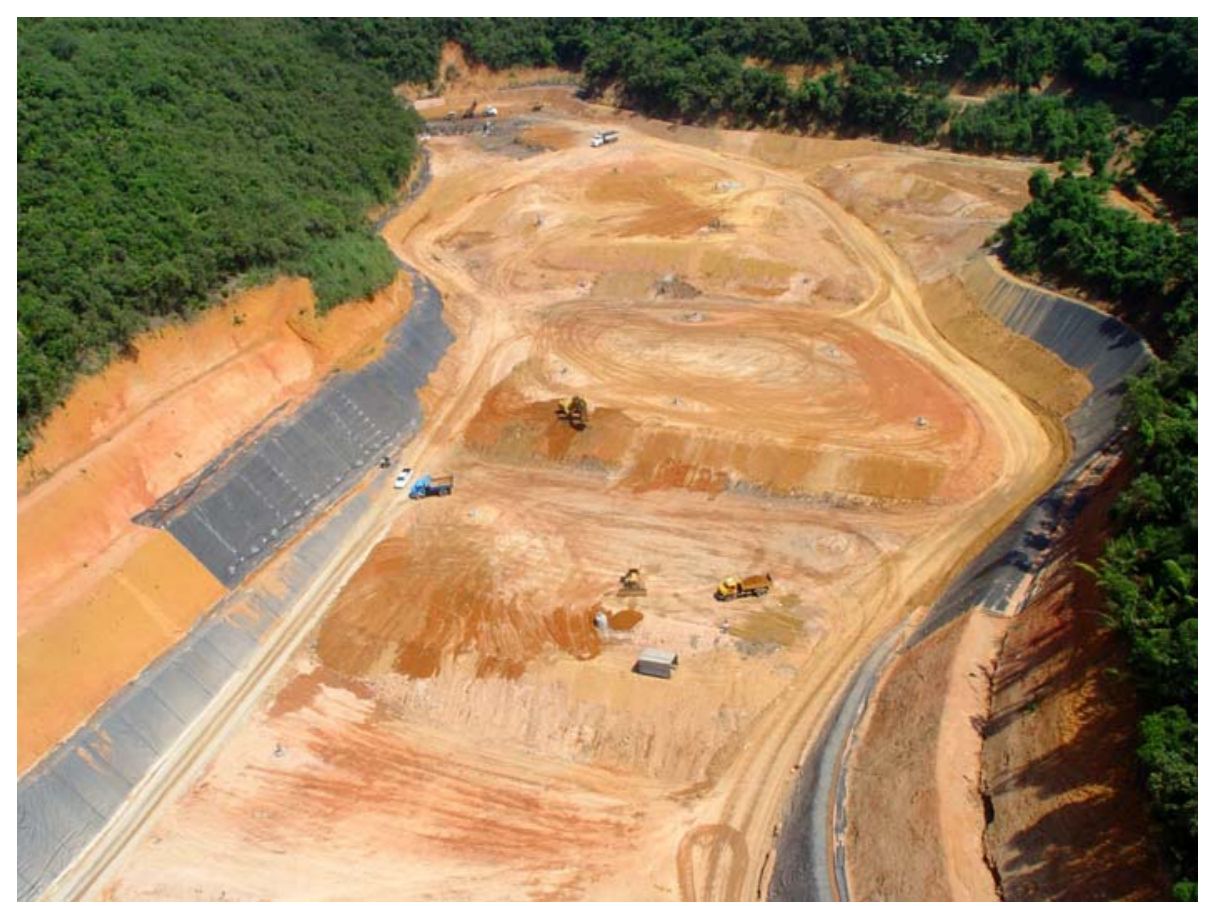

Figura 5: Aterro Sanitário - CTR Nova Iguaçu Fonte: CTR Nova Iguaçu (sem data)

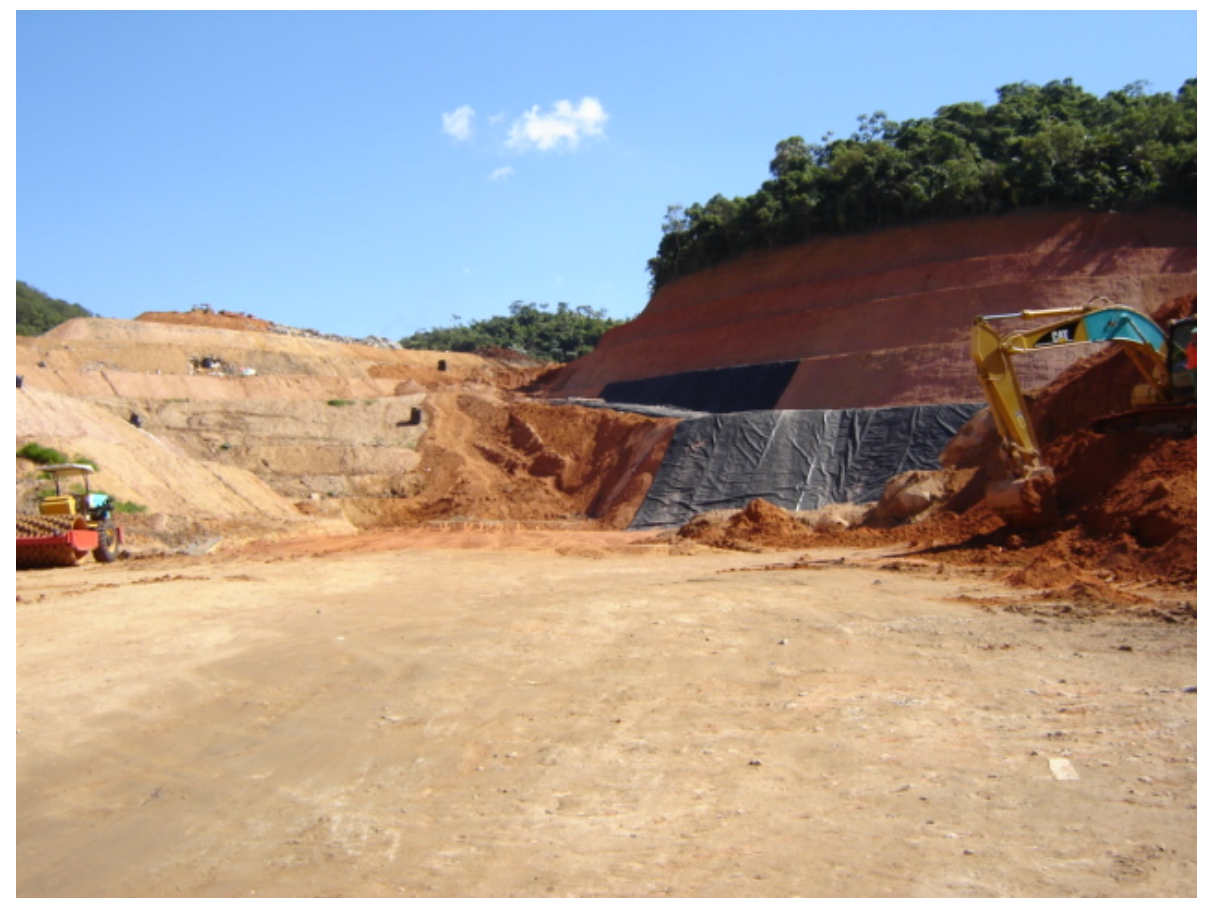

Figura 6: Células de disposição do aterro Gleice Donini de Souza - julho/2005 
Figura 7: Corte esquemático do aterro sanitário da CTR Nova Iguaçu

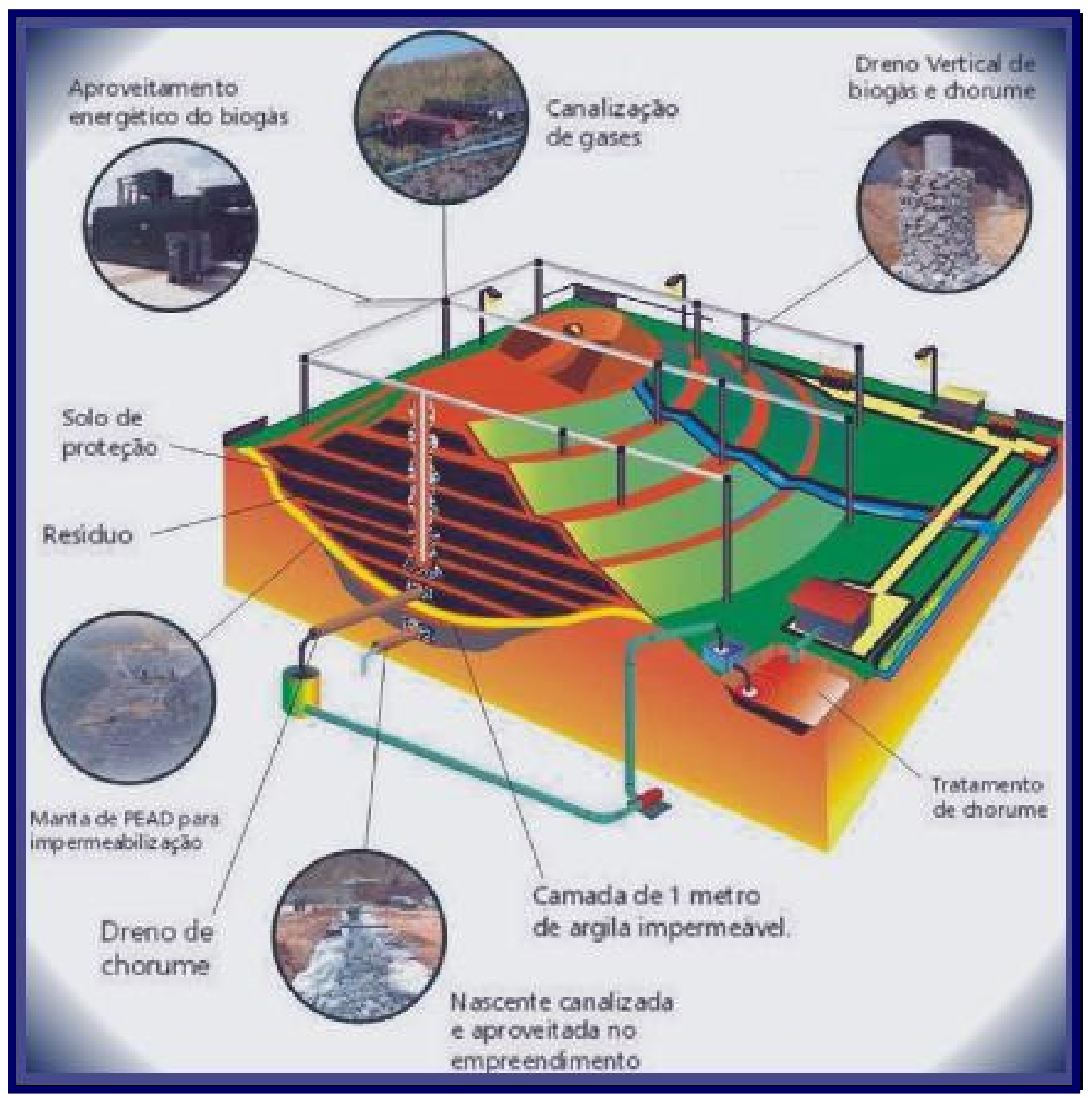

Fonte: CTR Nova Iguaçu.

\section{b) Unidade de Tratamento de Percolados (chorume)}

O sistema de evaporação de chorume é constituído por soprador de ar de combustão, tubo de combustão, câmara de vaporização, sistema de exaustão e sistema de descarga de sólidos. O equipamento garante a evaporação da água do percolado e a sedimentação de sólidos no interior da câmara de evaporação, que é posteriormente destinado no aterro sanitário. Os vapores gerados no 
processo passam por um filtro antes de serem lançados para a atmosfera. $\mathrm{O}$ monitoramento desses vapores é realizado periodicamente e os resultados encaminhados para o órgão estadual de meio ambiente. A energia utilizada para o funcionamento dos evaporadores é proveniente da coleta do biogás do aterro.

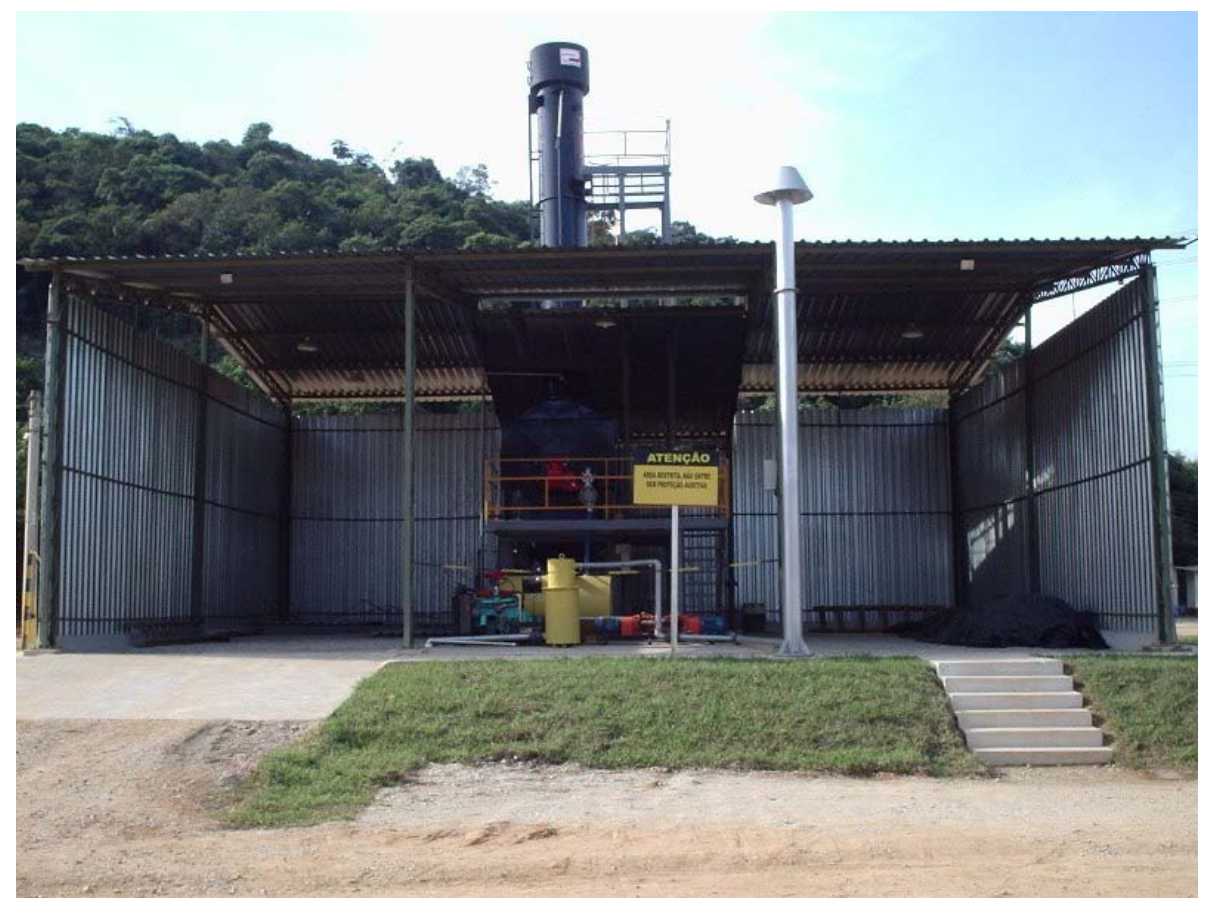

Figura 8: Sistema de Tratamento de percolados Fonte: CTR Nova Iguaçu (sem data)

\section{c) Unidade de Tratamento de Resíduos de Serviços de Saúde}

A Unidade de Tratamento de Resíduos de Serviços de Saúde, visa a desinfetar os resíduos patogênicos tanto de hospitais e clínicas quanto de ambulatórios de unidades industriais.

O equipamento selecionado para desinfecção corresponde ao chamado Sistema GDA, desenvolvido na Alemanha, que substitui a incineração dos resíduos. O Sistema GDA consiste num equipamento móvel compacto, que tritura a massa de resíduos e utiliza desinfecção térmica contínua.

Os resíduos desinfetados resultantes podem ser destinados a aterros sanitários convencionais, pois após o processo sua classificação enquadra-se como resíduo comum não infeccioso. 
A capacidade de tratamento do sistema é de 4,8 t/dia de resíduos. A unidade de tratamento está apta a receber qualquer tipo de resíduos infectantes provenientes dos estabelecimentos de saúde, sem restrições, exceto os que contenham resíduos radioativos, explosivos, produtos químicos perigosos, ou que sofram ou venham a sofrer alguma restrição legal, desde que acondicionados conforme normas vigentes.

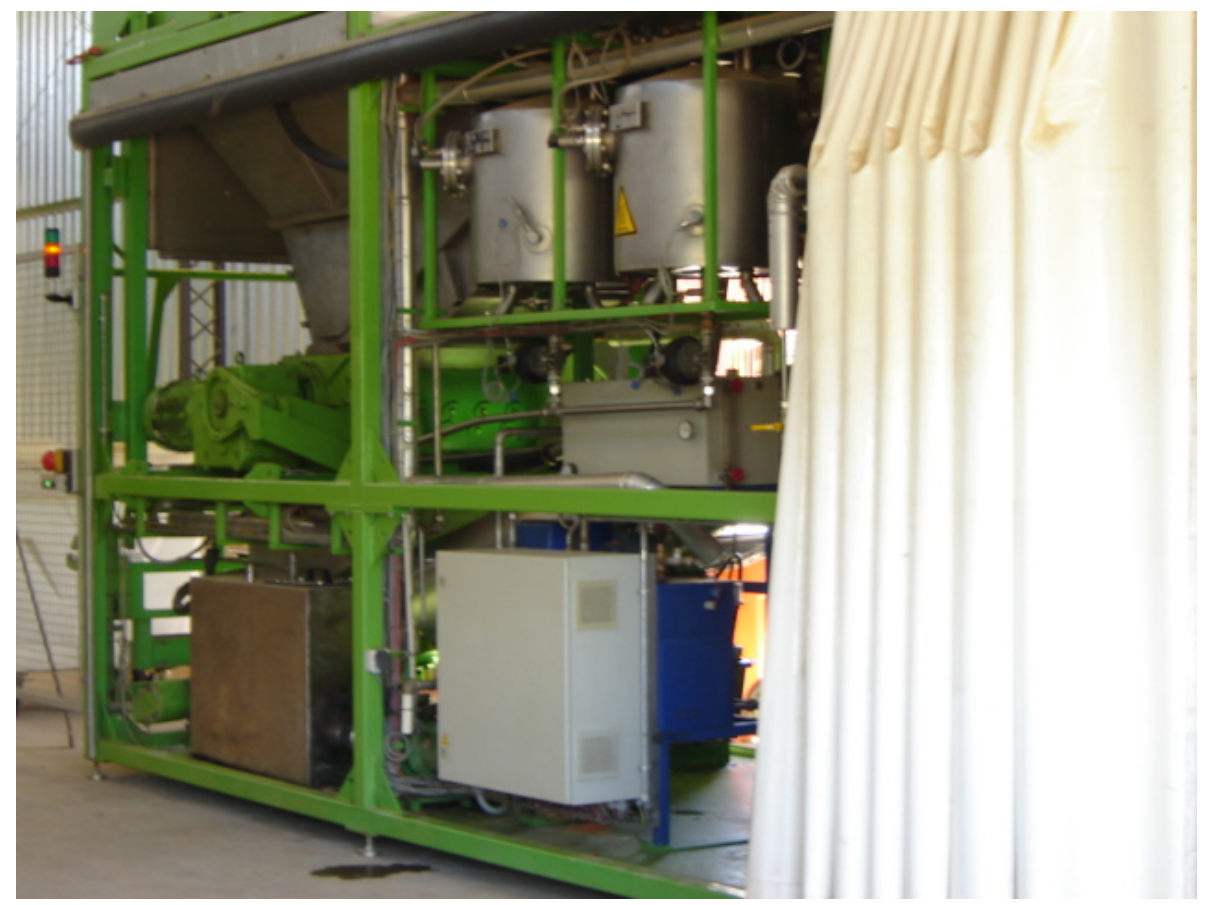

Figura 9: Sistema de Tratamento dos Resíduos de saúde Gleice Donini de Souza - julho/2005

\section{d) Sistema de Controle de Resíduos de Empresas Particulares}

O Sistema de Controle dos Resíduos Industriais, Comerciais e de Serviços visa promover o controle da qualidade do resíduo a ser recebido na CTR (garantindo que o resíduo será destinado de forma ambientalmente correta), bem como a arrecadação da concessionária, visando o correto repasse à Prefeitura Municipal de Nova Iguaçu.

O Sistema de Controle engloba um Sistema Informatizado específico e um Sistema por Procedimentos para o completo controle e gerenciamento.

O Sistema de controle é composto por: 
- Cadastramento dos geradores: cada estabelecimento gerador de resíduos deve preencher um formulário de cadastramento;

- Cadastramento dos transportadores: são cadastrados todos os veículos que fazem o transporte dos resíduos até o aterro;

- Manifesto dos Resíduos: é uma ficha que deve ser preenchida com a descrição dos resíduos e vincula a responsabilidade pelos resíduos ao gerador e ao transportador. Este manifesto é um importante instrumento de controle, pois é cadastrada no sistema da FEEMA para a disposição.

- Análise Laboratorial de amostra do resíduo de acordo com a NBR 10.004 da ABNT: para que a CTR possa receber um resíduo, é necessária uma análise laboratorial de acordo com a NBR 10.004, para que se comprove a classificação do resíduo e a viabilidade de recepção.

- Assinatura de contrato para prestação de serviços: para a recepção de resíduos na CTR, deve ser assinado contrato de prestação de serviços que garanta o pagamento do preço por tonelada de resíduos descarregados.

- Sistema Informatizado: programa de computador que armazena e gera dados que permitem o estabelecimento de um vínculo entre o controle administrativo e financeiro, no escritório da CTR, e o controle físico no campo.

- Controle Administrativo: efetua o cadastramento e controle de geradores e transportadores, realização de vistorias para cadastramento dos veículos das empresas transportadoras, análise e digitação de todos os manifestos de resíduos no Sistema Informatizado; elaboração de correspondências aos transportadores e geradores, análises de compatibilidade dos cadastros e dos Certificados de Aprovação ou Autorização da FEEMA, histórico das descargas e outras análises.

- Controle Físico: o controle da qualidade dos resíduos efetivamente descarregados é feito por meio da análise de amostras das cargas. As análises são feitas no laboratório instalado na própria CTR em parceria com o Centro de Tecnologia Ambiental (CTA) da Federação das Indústrias do Rio de Janeiro (FIRJAN) e de fiscais que trabalham durante toda a operação da CTR na frente de descarga. Eles acompanham todas as descargas e verificam o tipo de resíduo transportado. Cada carga de cada 
empresa é disposta em uma célula identificada em planta para que os resíduos possam ser localizados e identificados dentro do aterro a qualquer momento.

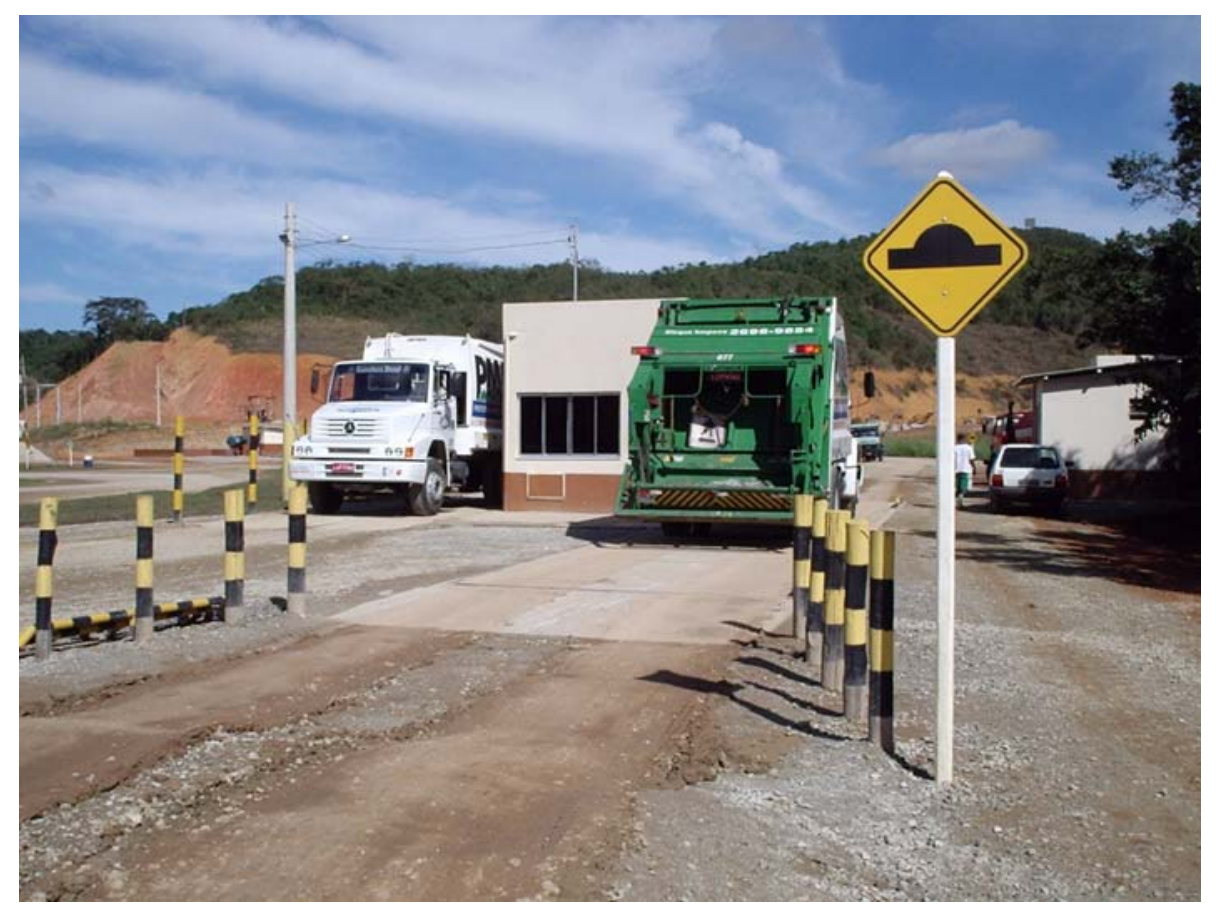

Figura 10: Caminhão de transporte de resíduos Fonte: CTR Nova Iguaçu (sem data)

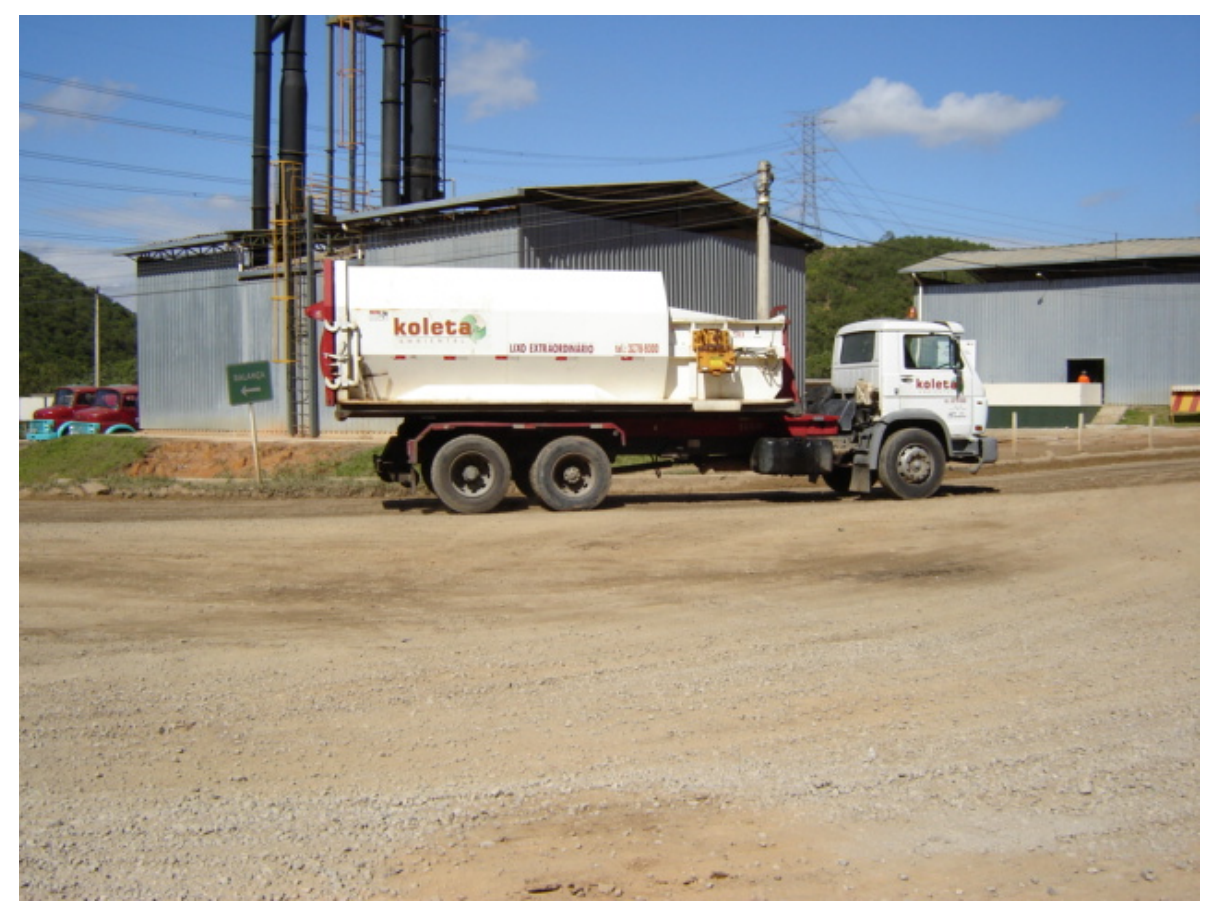

Figura 11: Caminhão de transporte de resíduos Gleice Donini de Souza - julho/2005. 
O monitoramento ambiental é rigoroso para o atendimento da legislação ambiental, das restrições da LO e das exigências do Ministério Público. Entre as ações de monitoramento, destacam-se: programa de assistência e manejo à fauna; bebedouro para a fauna; programa de sinalização na via e interna ao empreendimento; sistema integrado de controle de entrada de resíduos; enriquecimento vegetal das nascentes; monitoramento da qualidade da água (são coletadas amostras de água de 16 poços de monitoramento do lençol freático e de 6 pontos de água superficial para análises); e implantação e operação de viveiro de mudas.

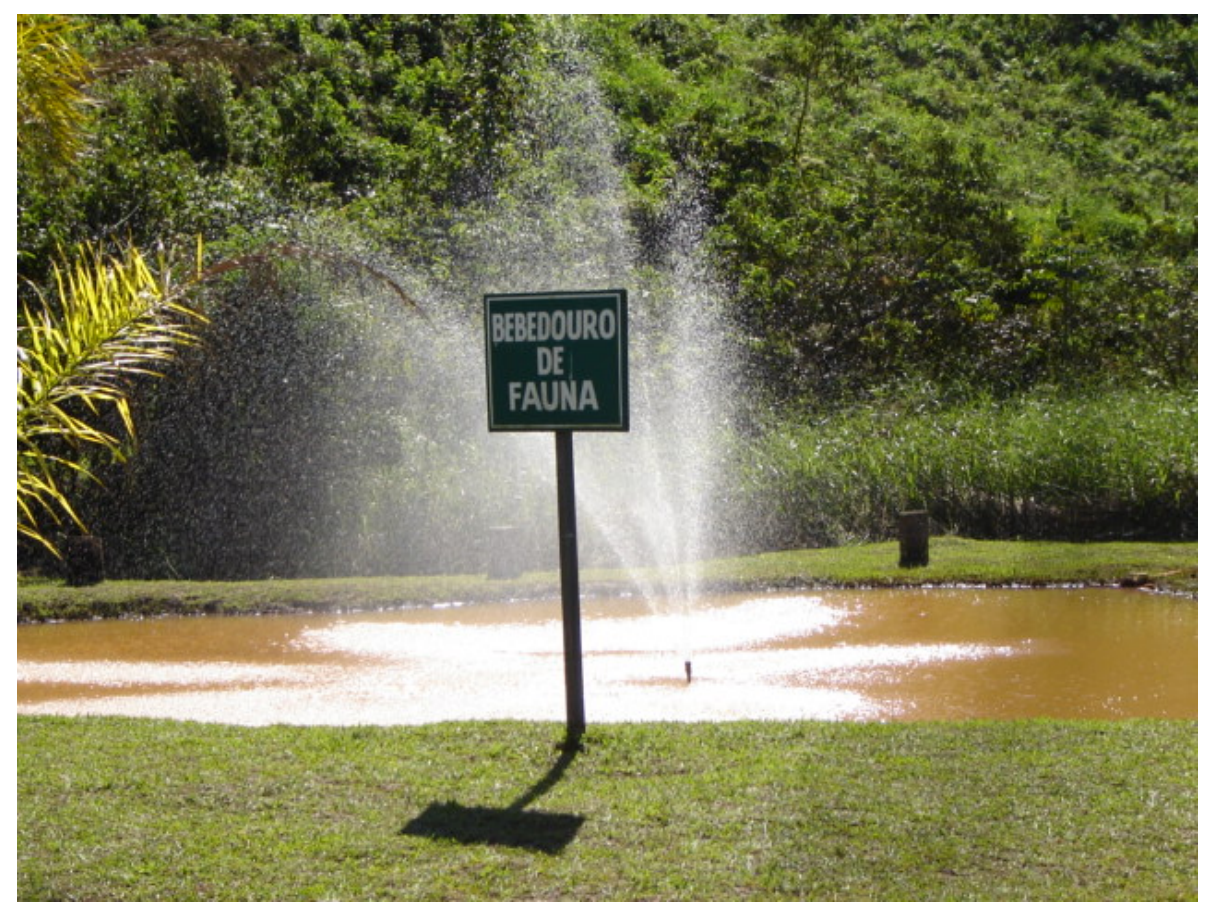

Figura 12: Bebedouro para a fauna

Gleice Donini de Souza - julho/2005.

\section{e) Centro de Educação Ambiental}

O Centro de Educação Ambiental é um espaço aberto à comunidade, escolas e colaboradores para ampliação do conhecimento, criação e discussão de 
questões voltadas à melhoria da qualidade de vida e proteção ao meio ambiente. No local são realizadas palestras, cursos, oficinas e eventos.

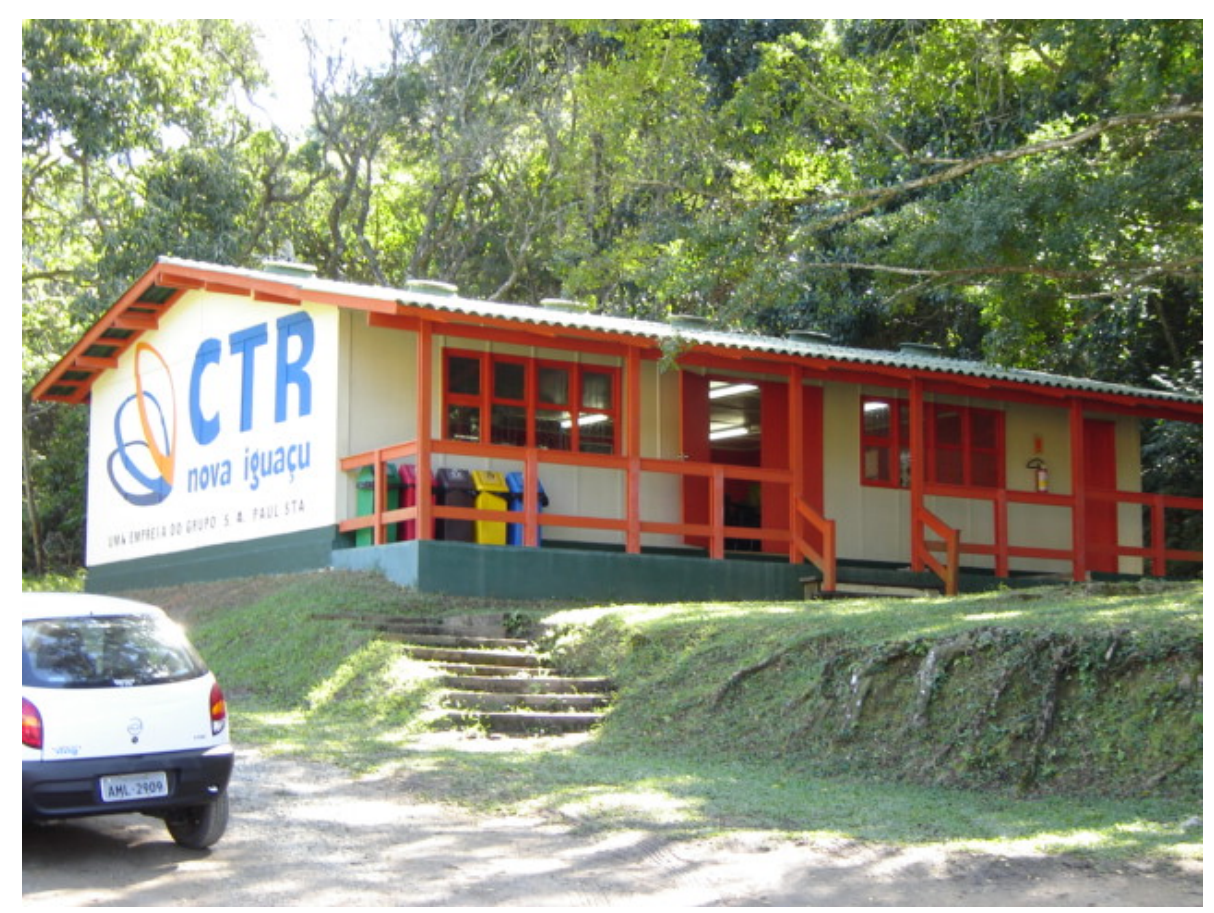

Figura 13: Centro de Educação Ambiental Gleice Donini de Souza - julho/2005.

\section{f) Viveiro de mudas de Mata Atlântica}

O antigo Lixão de Marambaia, local em que todo o lixo de Nova Iguaçu e Mesquita era depositado (sem qualquer controle) até a inauguração da Central de Tratamento de Nova Iguaçu, possuía 89 catadores que obtinham o seu sustento desta atividade. Parte desses antigos catadores foram contratados com carteira assinada para trabalharem no viveiro, realizar o plantio e paisagismo na Central de Tratamento. Dos demais, muitos foram absorvidos por outras empresas da cidade e, para os remanescentes, a Prefeitura montou uma cooperativa organizada que está separando e vendendo os resíduos provenientes da coleta seletiva, sem risco de contaminação. 


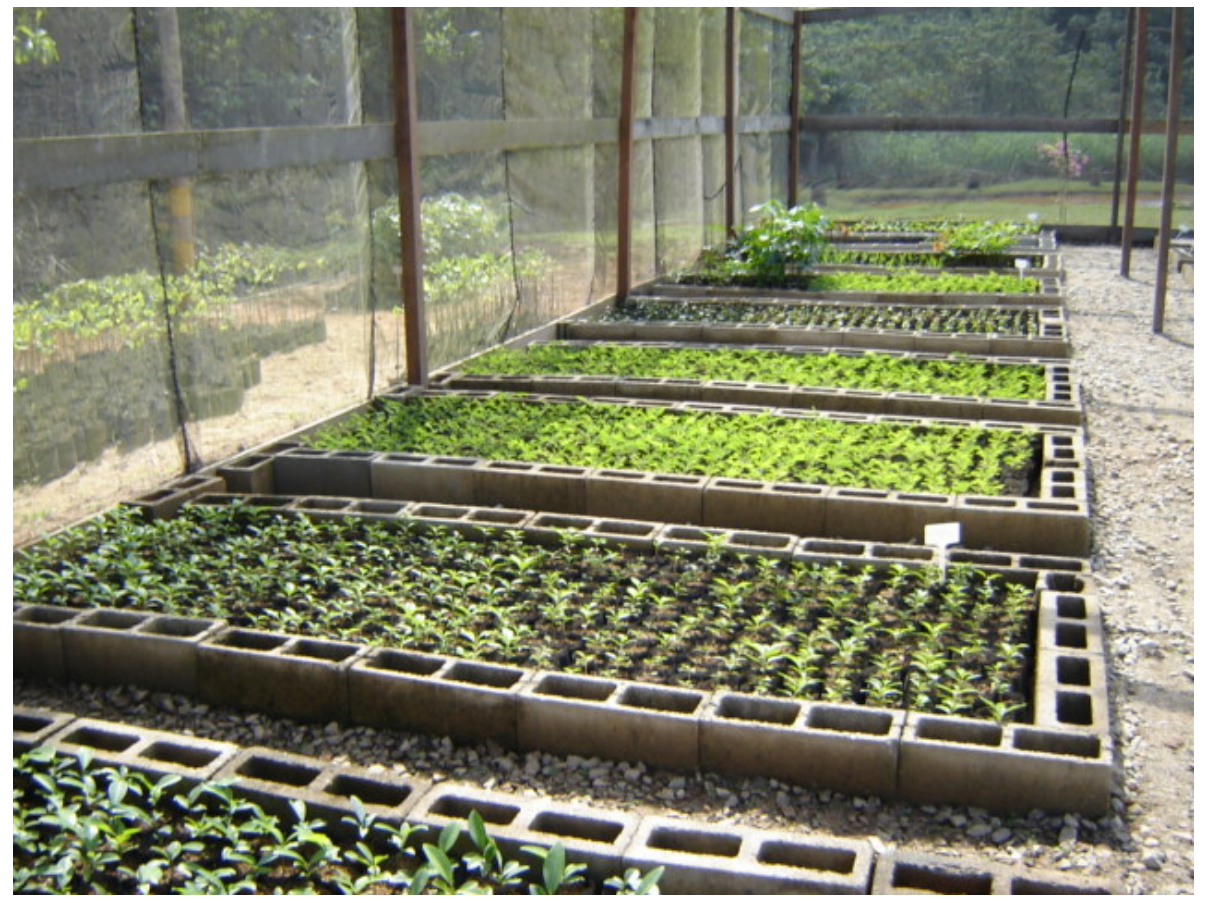

Figura 14: Viveiro de mudas nativas

Gleice Donini de Souza - julho/2005.

O encerramento e a recuperação do Lixão da Marambaia, foi incorporado ao projeto e toda a área está sendo coberta por mudas de Mata Atlântica onde será instalado um parque de lazer para a comunidade.

O município de Nova Iguaçu, como a grande maioria no país, desenvolveuse desordenadamente e sem a infra-estrutura urbana necessária à minimização dos impactos socioambientais. A ausência de uma política nacional sobre resíduos legitimou a disposição do lixo sem as exigências mínimas de neutralização dos impactos. Porém, a mudança no paradigma de gerenciamento dos resíduos tem proporcionado a remediação do passivo socioambiental gerado pelas práticas anteriores.

A adequada gestão dos resíduos diminui os impactos ambientais em nível local, com reflexos na escala global. O encerramento do lixão de Marambaia promoveu o término de uma prática degradante, que é a coleta de materiais recicláveis no lixão. Essas mudanças, acompanhadas da abertura de cooperativas de separação de materiais (provenientes da coleta seletiva implementada na cidade para aqueles ex-catadores que não foram absorvidos pela CTR Nova Iguaçu ou outras empresas), a médio/longo prazo podem induzir a 
uma mudança de postura da sociedade, com a ampliação da consciência ambiental e a conseqüente diminuição da exploração dos recursos naturais.

Nos lixões ou aterros sanitário, o gás gerado pela decomposição da matéria orgânica presente no lixo geralmente vai direto para a atmosfera. O gás do aterro ou biogás é composto pro aproximadamente $55 \%$ de gás metano. $\mathrm{O}$ poder de aquecimento global do metano é 21 vezes maior que do gás carbônico. Assim, cada tonelada de metano que vai para a atmosfera, representa o lançamento de 21 toneladas de gás carbônico.

O gás do aterro tem um grande potencial de aquecimento da atmosfera, se drenado, canalizado e encaminhado para tratamento específico, haverá uma redução de emissão de gases de efeito estufa. O metano que deixou de ser lançado na atmosfera pode ser negociado como "crédito de carbono" ou "emissões reduzidas de carbono".

O projeto de minimização de gases de efeito estufa e venda de certificado de emissões reduzidas de carbono, baseada no Protocolo de Kyoto é uma oportunidade de negócios. A instalação da CTR Nova Iguaçu reuniu os subsídios para a elaboração de um projeto de MDL. Para a realização deste projeto, foi constituída uma joint venture denominada NovaGerar entre a concessionária da CTR e a Ecosecurities, uma empresa especializada em finanças ambientais.

O objetivo do projeto é aprimorar as condições ambientais da CTR de Nova Iguaçu, seguindo às diretrizes do Mecanismo de Desenvolvimento Limpo. No capítulo 5 discutiremos o projeto NovaGerar, primeiro do mundo a ser registrado no Conselho Executivo da ONU no Mecanismo de Desenvolvimento Limpo, no dia 18 de novembro de 2004. 


\section{CAPÍTULO 5: NOVAGERAR - O PRIMEIRO PROJETO DE MDL REGISTRADO NO MUNDO}

O capítulo 5, denominado NovaGerar: o primeiro projeto de MDL registrado no mundo âmbito do Protocolo de Kyoto trará em sua primeira parte a discussão da oportunidade de desenvolvimento de um projeto de redução de GEE a partir da instalação da Central de Resíduos de Nova Iguaçu. A construção do aterro sanitário propiciou os elementos necessários ao cumprimento dos requisitos para projetos de MDL.

Para que um projeto seja aprovado e se torne uma atividade de MDL deve, necessariamente, passar por sete etapas do ciclo de projeto. Na segunda parte deste capítulo abordaremos cada etapa pela qual o projeto NovaGerar foi submetido e seus principais aspectos, para que possamos ter um entendimento geral dos trâmites necessários para aprovação de um projeto de MDL.

A terceira parte do capítulo traz os benefícios ambientais e sociais advindos do NovaGerar.

\subsection{A oportunidade a partir da CTR Nova Iguaçu}

Os resíduos gerados pelas atividades humanas, se devidamente gerenciados, têm como destinação final os aterros sanitários. A decomposição anaeróbia de resíduos sólidos compostos por matéria orgânica resulta na liberação de biogás.

O Biogás é uma mistura gasosa, combustível, resultante da fermentação anaeróbica da matéria orgânica (decomposição de matérias orgânicas, em meio anaeróbio, por bactérias denominadas metanogênicas). A proporção de cada gás na mistura depende de alguns parâmetros, tais como o tipo de digestor e o substrato a digerir. De qualquer forma, esta mistura é essencialmente constituída por metano ( $\mathrm{CH} 4)$, com valores médios na ordem de 55\%, e por dióxido de carbono (CO2) com aproximadamente 35 a 45\% de sua composição, estando o seu poder calorífico diretamente relacionado com a quantidade de metano existente na mistura gasosa. 
O gás metano tem o Global Warming Potential (GWP) 21 vezes maior que o gás carbônico, portanto, cada tonelada de metano que vai para a atmosfera, representa o lançamento de 21 toneladas de gás carbônico. Projetos que envolvam a redução do gás metano, a partir do aproveitamento de matéria orgânica depositada em aterros sanitários, são uma alternativa de melhoria ambiental local e global.

Atualmente existem duas situações possíveis para o aproveitamento do biogás. O primeiro caso consiste na queima direta em aquecedores, esquentadores, fogões, caldeiras. O segundo caso diz respeito à conversão de biogás em eletricidade. Isto significa que o biogás permite a produção de energia elétrica e térmica. Em vários países o biogás que é produzido em aterros sanitários é aplicado como fonte energética em processos sanitários, e em alguns casos existe até a comercialização do biogás para uso nas indústrias.

O Protocolo de Kyoto, por meio do Mecanismo de Desenvolvimento Limpo, prevê o financiamento de fontes energéticas limpas em países em desenvolvimento, tornando o aproveitamento do biogás viável à geração de energia elétrica e térmica, resultando na geração de créditos de carbono, dada a redução das emissões de metano para a atmosfera.

A estrutura construída para a CTR possibilitou a criação de um projeto de minimização de gases de efeito estufa e venda de certificado de emissões reduzidas de carbono. Para este projeto foi constituída uma "joint venture" entre a S.A Paulista, que desenvolveu a CTR Nova Iguaçu, e a empresa ambiental Ecosecurities - empresa financeira que lida com questões ambientais e é especializada em desenvolvimento de projetos de mitigação de GEE denominada NovaGerar. O objetivo da NovaGerar é aprimorar as condições ambientais da CTR de Nova Iguaçu de acordo com as diretrizes do Mecanismo de Desenvolvimento Limpo.

No projeto NovaGerar o gás metano que é produzido no aterro é drenado, canalizado e enviado a equipamentos específicos, ao invés de ser lançado diretamente na atmosfera. Estes equipamentos específicos podem ser "flares" (equipamento para queima eficiente e controlada) nos quais o metano é queimado e totalmente transformado em gás carbônico, ou pode ser um conjunto de motores e geradores para produção de energia elétrica. Neste primeiro 
momento o biogás está sendo utilizado como fonte de energia para o funcionamento da unidade de tratamento de chorume, futuramente, prevê-se a geração de energia elétrica com capacidade instalada de $12 \mathrm{MW}$.

O projeto atraiu o interesse do Governo dos Países Baixos e do Banco Mundial (Bird) para a compra dos créditos de carbono, baseada no MDL. A diferença entre as toneladas de carbono que seriam lançadas na atmosfera sem 0 projeto e as que são lançadas com o projeto é denominada de emissões reduzidas ou créditos de carbono. O contrato de compra de emissões reduzidas de carbono - Emissions Reductions Purchase Agreement (ERPA) pelo Banco Mundial como depositário (trustee) do MDL do Governo dos Países Baixos foi assinado em 2005. Coube ao Banco Mundial o acompanhamento, auditorias e verificações para a certificação e registro do projeto, que foi o primeiro projeto de MDL aprovado no mundo.

Foram negociados com o Banco Mundial os créditos de carbono gerados pelo empreendimento até 2012. Como se espera que haja um aumento do valor dos créditos no mercado internacional, pode-se vender os CERs futuros (período de 2.013 até 2.022).

A estimativa para a geração de gás para o cálculo das reduções de emissões para a assinatura do contrato é baseado em modelo da EPA (Environmental Protection Agency - USA), porém seu faturamento anual é baseado nas medições "in loco" da vazão e composição do gás.

O projeto prevê, portanto, investimentos em um sistema de coleta de gás e em uma usina geradora de eletricidade modular (com um potencial de capacidade esperado de 12 MW após alguns anos de operação), para capturar o metano do aterro e utilizá-lo na geração de eletricidade para abastecer a rede de energia elétrica, reduzindo as emissões em estimadas 14 milhões de toneladas de $\mathrm{CO} 2$, durante os próximos 21 anos. Em paralelo, será iniciado um programa social baseado na eletrificação de edificações públicas que utilizarão a energia elétrica disponibilizada pelo projeto. É uma parceria entre a empresa NovaGerar e a prefeitura municipal de Nova Iguaçu, com vistas a promover melhorias locais e consequentemente globais.

A parceria entre a S.A. Paulista e a Ecosecurities foi desfeita em 2005, devido a diferença de porte das empresas, o que gerou um desequilíbrio na 
capacidade de investimento por parte da Ecosecurities. Porém, durante todo o processo de elaboração e registro do projeto, a Ecosecurities esteve presente, conforme discutiremos a seguir.

\subsection{Etapas do projeto NovaGerar}

Para que um projeto, sob as regras do $\mathrm{MDL}$, resulte em reduções certificadas de emissões, as atividades de projeto devem, necessariamente conforme dito anteriormente, passar por sete etapas do ciclo do projeto: elaboração de documento de concepção de projeto (Project Design Document PDD), usando metodologia de linha de base e plano de monitoramento aprovados; validação (verifica se o projeto está em conformidade com a regulamentação do Protocolo de Kyoto); aprovação pela Autoridade Nacional Designada; submissão ao Conselho Executivo para registro; monitoramento; verificação/certificação; e emissão de CERs segundo o acordo do projeto.

O projeto NovaGerar foi submetido a essas sete etapas, as quais descreveremos e analisaremos a seguir.

\subsubsection{Documento de Concepção do Projeto (Project Design Document - PDD) ${ }^{70}$}

O Documento de Concepção do Projeto está dividido em sete seções e inclui cinco anexos: Descrição geral das atividades do projeto; Metodologia da linha de base; Duração da atividade do projeto; Plano de monitoramento; Cálculo de emissões de GEE pelas fontes; Impactos ambientais; Comentários das Partes Interessadas (Stakeholders); Anexo 1: Informações para contato sobre os participantes do projeto; Anexo 2: Informações sobre financiamento público; Anexo 3: Nova metodologia de linha de base; Anexo 4: Nova metodologia de monitoramento; Anexo 5: Dados da linha de base.

\footnotetext{
70 Todas as informações descritas nesta seção foram baseadas no Projeto de Aproveitamento do Biogás de Aterro Sanitário - NovaGerar Documento de Concepção do Projeto. Preparado para a Unidade de Financiamento de Carbono (PCF - Prototype Carbon Fund) do Banco Mundial. Fevereiro de 2004.
} 
Apresentaremos o PDD de forma sumarizada, porém em algumas seções, faremos a transcrição do documento, para que não haja distorções e um maior entendimento do projeto.

\subsubsection{Descrição Geral das Atividades do Projeto}

A Descrição geral das atividades do projeto apresenta um resumo do histórico da concepção do projeto, quantificação da capacidade de geração de créditos de carbono, principais impactos sociais e ambientais decorrentes do projeto, participantes, que no caso são Ecosecurities, S.A. Paulista, EnerG (empresa britânica especialista em aproveitamento energético em aterros sanitários) e o World Bank Netherlands Clean Development Facility (WB NCDF _ Fundo de Desenvolvimento Limpo dos Países Baixos do Banco Mundial). Além disso traz a descrição técnica das atividades do projeto, incluindo a tecnologia a ser empregada:

"A tecnologia de ponta para coleta de gás inclui:

- Células de aterro revestidas com uma membrana de poliuretano impermeável de alta-densidade;

- Resíduos de água canalizados e tratados em uma usina de tratamento de água usada;

- Reservatórios verticais usados para extrair gás;

- Espaçamento do reservatório perfeito para coleta máxima de gás, o que minimiza os custos;

- Cabeçotes de gás projetados como um sistema de looping, a fim de permitir perda total ou parcial da função do cabeçote em uma direção, sem perder a funcionalidade do sistema de gás e;

- Sistemas de extração e de armazenamento de condensados projetados em pontos baixos estratégicos através do sistema de gás.

Serão feitos esforços para minimizar os problemas da administração de condensados.

Tecnologia de geração de energia: 
Será instalada uma usina modular de geração de energia elétrica. As unidades modulares do sistema gerador tornam possível a adaptação do equipamento para os volumes de gás específicos do local. Conforme os volumes de gás diminuem com o tempo, os módulos podem ser recolocados em outros locais." ${ }^{71}$

A tecnologia empregada pela CTR Nova Iguaçu permite gerenciar o biogás, resultando em atividades complementares ao aterro sanitário, que são a coleta e queima do metano, reduzindo seu efeito de gás de efeito estufa, além de possibilitar a geração de energia.

\subsubsection{Metodologia da linha de base}

A metodologia da linha de base foi desenvolvida de forma específica para o projeto de aproveitamento do gás de aterro sanitário da NovaGerar e foi denominada AM0003: Simplified Financial Analysis for Landfill Gás Capture Projects - Análise Simplificada para Projetos de Captura de Gás de Aterro Sanitário. O PDD deve conter uma descrição de como a metodologia é aplicada ao contexto da atividade do projeto.

"A metodologia da linha de base foi aplicada da seguinte maneira:

1. Análise dos aspectos econômicos atrativos da alternativa do projeto sem as receitas dos créditos de carbono usando um cálculo de comparação da Taxa Interna de Retorno dos resultados com uma expectativa de retorno razoável sobre os investimentos no Brasil. Os resultados mostram que o projeto não apresenta resultados economicamente atrativos.

2. O único outro cenário plausível é a continuação da não utilização do gás de aterro sanitário. Este cenário é determinado como o cenário de linha de base com base na análise das práticas atuais e de

${ }^{71}$ NOVAGERAR. Projeto de Aproveitamento do Biogás de Aterro Sanitário. Documento de Concepção do Projeto. Preparado para a Unidade de Financiamento de Carbono (PCF Prototype Carbon Fund) do Banco Mundial. Fevereiro de 2004. p. 6-7. 
regulamentações atuais e pressupostas no setor de administração de lixo." ${ }^{72}$

A metodologia foi aplicada em sete etapas com as seguintes considerações:

"Etapas 1 e 2 : Cenários de linha de base possíveis e plausíveis

Alternativa 1: A operadora do aterro continuaria as atividades atuais conforme a prática usual de não coletar e incinerar o gás de aterro a partir de suas operações com lixo. Neste caso, não seria gerada energia nos locais e o sistema de energia brasileiro continuaria sem ser afetado.

Alternativa 2: A operadora de aterro investiria em coleta de LFG e em incineração, mas não em geração de energia. O sistema de energia brasileiro continuaria sem ser afetado.

Alternativa 3: A operadora de aterro investiria em equipamento de geração de energia de gás de aterro sanitário (a atividade proposta pelo projeto). A operação reduziria bastante a geração de energia de outras fontes conectadas à rede."73

A legislação ambiental brasileira, considerada por alguns especialistas como uma das mais rigorosas do mundo, não prevê que os aterros sanitários façam a coleta e disposição do biogás gerado pela decomposição da matéria orgânica. A situação torna-se ainda mais grave quando verificamos, conforme dito anteriormente, que 63,6\% dos resíduos urbanos produzidos no Brasil têm como destino final os lixões, que não possuem nenhum controle ambiental, não há tratamento do chorume e muito menos controle e queima do biogás produzido. $\mathrm{O}$ 'Lixão de Marambaia' é um caso típico, em que houve a disposição de lixo por

72 NOVAGERAR. Projeto de Aproveitamento do Biogás de Aterro Sanitário. Documento de Concepção do Projeto. Preparado para a Unidade de Financiamento de Carbono (PCF Prototype Carbon Fund) do Banco Mundial. Fevereiro de 2004. p. 11.

${ }^{73}$ NOVAGERAR. Projeto de Aproveitamento do Biogás de Aterro Sanitário. Documento de Concepção do Projeto. Preparado para a Unidade de Financiamento de Carbono (PCF Prototype Carbon Fund) do Banco Mundial. Fevereiro de 2004. p. 11. 
mais de 15 anos sem qualquer tipo de licenciamento ambiental ou sem seguir qualquer tipo de regulamentação ambiental.

O aumento do consumo acarreta no aumento da produção de resíduos. Dessa forma, para que os impactos ambientais sejam mitigados, a legislação deve ser revista tornando obrigatória a construção de aterros sanitários, que façam o tratamento do chorume e o gerenciamento do biogás.

Enquanto a obrigatoriedade não ocorre, os projetos de aterro sanitário que fazem o gerenciamento do biogás tornam-se um diferencial passível de serem enquadrados como atividades de MDL.

Uma das alternativas dos cenários de linha de base proposta pelo projeto NovaGerar leva em consideração a não obrigatoriedade da coleta do biogás, mantendo o aterro funcionando sem essa premissa, portanto sendo business as usual, além de não modificar o sistema de energia brasileiro, pois não há geração de energia a partir do biogás.

A segunda alternativa proposta pelo projeto é a instalação de equipamentos para a coleta e incineração do LFG (Landfill gas - biogás), o que não é plausível para a operadora, tendo em vista o valor do investimento sem retorno financeiro. Essa alternativa também não acarretaria mudanças ao sistema de energia brasileiro, conforme declarado no documento abaixo:

"Determinada a situação regulamentar no Brasil e a localização e as condições dos dois aterros, a realização da alternativa 2 não é necessária e também não seria um curso de ação economicamente atrativo para o proprietário ou a operadora do aterro. Portanto, não se considera plausível a alternativa." ${ }^{14}$

A terceira alternativa, de atividade proposta pelo projeto, prevê o investimento em equipamentos de geração de energia por meio do biogás. Essa alternativa resultaria em coleta de biogás, portanto este deixaria de ser emitido diretamente para a atmosfera, além de possibilitar a geração de energia, o que resulta em mudanças no sistema de energia.

\footnotetext{
${ }^{74}$ NOVAGERAR. Projeto de Aproveitamento do Biogás de Aterro Sanitário. Documento de Concepção do Projeto. Preparado para a Unidade de Financiamento de Carbono (PCF Prototype Carbon Fund) do Banco Mundial. Fevereiro de 2004. p. 11.
} 
Dentre as alternativas de cenário de linha de base suscitadas pelo projeto, tornam-se plausíveis as alternativas 1 e 3.

\section{Etapas 3, 4 e 5: Análise e Seleção financeira do cenário de linha de}

base:

A Etapa 3 para determinação da linha de base do projeto prevê o cálculo da Taxa Interna de Retorno conservadora para a atividade de projeto proposta, não levando em consideração o financiamento do carbono. Dessa forma, para o projeto NovaGerar os principais retornos financeiros derivados da coleta de gás são a venda de eletricidade, o que o torna dependente dos fatores relacionados ao setor energético brasileiro.

O setor energético brasileiro fundamenta-se na produção de energia por meio das hidrelétricas, tendo em vista que o país tem poucas reservas de óleo e de carvão, mas é rico em recursos hidrológicos.

"Na metade dos anos 80, o setor de energia do Brasil passou por uma séria crise financeira, o que levou à construção de muitas usinas elétricas - principalmente hidros. Em 1993, a descentralização do setor de energia começou, o que contribuiu para a demora na implementação dos projetos planejados.

O atual plano de expansão de 10 anos do Brasil 2000/2009 reduz a importância das hidros a curto prazo, mas enfatiza novamente sua função no término do período. Entretanto, não está claro como os investimentos em larga escala serão financiados, particularmente em vista da tendência à descentralização do setor." ${ }^{75}$

Dessa forma, o investimento em fontes alternativas de energia, como a utilização de biogás de aterros sanitários é considerada arriscada. A dificuldade de se obter os valores exatos de biogás produzido por aterros torna-se um

\footnotetext{
${ }^{75}$ NOVAGERAR. Projeto de Aproveitamento do Biogás de Aterro Sanitário. Documento de Concepção do Projeto. Preparado para a Unidade de Financiamento de Carbono (PCF Prototype Carbon Fund) do Banco Mundial. Fevereiro de 2004. p. 15.
} 
complicador para o investimento nessa fonte alternativa de energia, pois na prática pode ser inferior ao cálculo e à demanda.

A análise financeira conduzida pelo Projeto, considerando o exposto acima e a partir de um ponto de vista de decisão de investimento mostrou que a Taxa Interna de Retorno do projeto sem o financiamento de carbono é negativa.

Para o cálculo foram utilizadas suposições conservadoras, visando a melhor Taxa de Retorno:

"Presumiu-se que a taxa média de deslocamento do lixo em Adrianópolis era igual ao pico da taxa de deslocamento de lixo de 3.300 toneladas por dia, projetada atualmente para só ocorrer em 2023, o ano final do período de abrangência do projeto. Portanto, os volumes de gás de aterro a serem gerados no local aumentariam significativamente.

O modelo de geração de gás de aterro usado, o US EPA First Order Decay Model (Modelo de Decomposição de Primeira Ordem da EPA nos Estados Unidos), tem um erro inerente de até 50\%. Na melhor Taxa Interna de Retorno deste caso presumiu-se que havia uma margem de erro de $0 \%$, portanto, aumentando mais uma vez a expectativa de volumes de gás de aterro no local e a expectativa de eletricidade a ser gerada no local.

Presumiu-se que o projeto tinha acesso ilimitado a capital para investir em todo o equipamento necessário para usar a maior quantidade de gás produzida. Presumiu-se que a taxa de câmbio US\$:Rs\$ estava fixa em 3,0 (porque a de novembro de 2002 era 3,565) e a tarifa de eletricidade fixada em $\mathrm{R} \$ 130,00$ no período de 21 anos (equivalente a U\$ 43,30/MWh nesta taxa de câmbio, e não de U\$34,90 nas taxas de câmbio atuais). Essas melhores pressuposições de caso foram inseridas nos modelos e na análise financeira para recalcular a Taxa Interna de Retorno. A Taxa Interna de Retorno (sem carbono) é negativa e ainda exposta a uma série de riscos (projeto, país, moeda, etc.)." ${ }^{76}$

\footnotetext{
${ }^{76}$ NOVAGERAR. Projeto de Aproveitamento do Biogás de Aterro Sanitário. Documento de Concepção do Projeto. Preparado para a Unidade de Financiamento de Carbono (PCF Prototype Carbon Fund) do Banco Mundial. Fevereiro de 2004. p. 15-16.
} 
A Taxa de Retorno do investimento para a produção de energia não mostrou-se lucrativa para a operadora, o que resume o cenário de linha de base a uma única alternativa, a continuação da operação do aterro sem qualquer tipo de tratamento do biogás, ou seja, business as usual.

\section{Etapas 6 e 7: Desenvolvimento da linha de base com relação ao} tempo e à descrição dos cenários

A partir da seleção da Alternativa mais plausível para o cenário de linha de base, as Etapas 6 e 7 desse processo contemplam a descrição completa e análise do cenário da linha de base durante o período de crédito.

Os fatores determinantes para a escolha da Alternativa 1, Business as Usual, foram as regulamentações sobre aterro aplicáveis ao local (ou a falta de regulamentações para ser mais coerente) e a não viabilidade econômica para a utilização do gás de aterro.

A linha de base ficou assim definida:

"Nenhum tipo de coleta e tratamento de gás de aterro nos dois locais, desta maneira, a liberação sem obstáculos do gás de aterro à atmosfera até um tempo futuro em que a coleta e o tratamento de gás de aterro será ou exigida por lei ou se tornar um curso de ação economicamente atrativo. Esta alteração no possível futuro da linha de base será determinada pelo plano de monitoramento elaborado para o projeto." 77

Este cenário de linha de base é o fator determinante para o cálculo da Redução de Emissões do projeto conforme o plano de monitoramento .

A legislação brasileira não exige o controle e tratamento do biogás, e essa situação ficou refletida no contrato entre a operadora da CTR Nova Iguaçu e a prefeitura, que apenas prevê a instalação de uma rede de dreno de gás rudimentar no lixão de Marambaia, para evitar os riscos de explosões e para Adrianópolis não foi feita exigência alguma de ventilação ou queima do biogás. 
Dessa forma, as reduções de emissão geradas em Marambaia serão descontadas em $20 \%{ }^{78}$, que é o percentual calculado de gás que deveria ser queimado para mitigar os riscos de explosão, cumprindo assim os requerimentos exigidos nos documentos da proposta de concessão.

A linha de base será revista a cada 7 anos, para assegurar que condiz com a realidade. Além disso, as alterações na legislação brasileira quanto ao gerenciamento dos aterros sanitários será acompanhada anualmente como parte do Plano de Monitoramento.

Os projetos de MDL devem ser adicionais, ou seja, as emissões antropogênicas de GEE devem ser menores que as que ocorreriam na ausência do projeto; e/ou se o seqüestro de carbono for maior que aquele que ocorreria na ausência do projeto. Portanto, a linha de base de um projeto de MDL é o cenário que representa as emissões antropogênicas de GEE que ocorreriam na ausência do projeto.

A partir da análise financeira conduzida para a definição da linha de base, concluiu-se que a implementação do projeto não é o curso econômico mais atraente, o projeto não faria parte do cenário de linha de base, portanto pode-se concluir que o Projeto NovaGerar é adicional.

Além disso, a operadora acredita que o valor adicional gerado pela venda dos créditos de carbono aumentará o retorno financeiro do projeto, fato suficiente para justificar os riscos do investimento. Com a entrada em vigor do Protocolo de Kyoto, a demanda por créditos de carbono tem aumentado consideravelmente, valorizando, portanto, seu preço no mercado. Justificando os riscos dos investimentos nestes projetos.

No cenário de linha de base de referência do projeto, a ausência de coleta de biogás (em Marambaia e Adrianópolis) seria responsável pela emissão de aproximadamente 70.000 toneladas de metano por ano. Multiplicando esse valor pelo GWP do metano (que equivale a 21 vezes o GWP do dióxido de carbono), temos cerca de 800.000 toneladas de CO2e por ano. As emissões

77 NOVAGERAR. Projeto de Aproveitamento do Biogás de Aterro Sanitário. Documento de Concepção do Projeto. Preparado para a Unidade de Financiamento de Carbono (PCF Prototype Carbon Fund) do Banco Mundial. Fevereiro de 2004. p. 17.

${ }^{78}$ Devido ao fato de que o lixão de Marambaia é distante de qualquer ocupação humana, assumiuse que no máximo $20 \%$ do gás teria necessidade de ser queimado para evitar explosões. Pelo sistema rudimentar requerido, provavelmente menos de $20 \%$ seria capturado na prática. 
acumuladas de $\mathrm{CO} 2 \mathrm{e}$ sem o projeto, ao longo do período de creditação são estimadas de forma conservadora em mais de 16,8 milhões de toneladas.

Com a implementação do projeto NovaGerar as emissões serão reduzidas:

"O cenário do projeto NovaGerar é baseado na coleta e combustão do gás de aterro sanitário para a geração de eletricidade. A combustão do gás de aterro para produzir eletricidade, irá converter o metano com um alto potencial para outro com menor potencial, que é o dióxido de carbono, resultando portanto em reduções significativas de emissão de GEE. Através da utilização das predições do Modelo US EPA e da projeção da quantidade de gás de aterro que sofrerá combustão nos motores ou queimadores, estima-se que somente 2.5 milhões de toneladas de $\mathrm{CO} 2$ e serão emitidas como emissões fugitivas no cenário do projeto, durante o período entre 2003 e 2023,. enquanto que, no cenário de linha de base, esta estimativa sobe para 16,8 milhões de tCO2e durante o mesmo período.

Desta forma, a captura e combustão do gás metano de aterro sanitário para geração de eletricidade irá resultar, efetivamente, na diminuição de 14,07 milhões de toneladas de CO2, durante 21 anos, já que as ERs serão descontadas em 20\% para Marambaia, de forma a manter as estimativas conservadoras." ${ }^{179}$

A redução das emissões de metano contribuem para o objetivo final da Convenção de Mudanças Climáticas, mitigando os impactos globais das emissões de GEE.

79 NOVAGERAR. Projeto de Aproveitamento do Biogás de Aterro Sanitário. Documento de Concepção do Projeto. Preparado para a Unidade de Financiamento de Carbono (PCF Prototype Carbon Fund) do Banco Mundial. Fevereiro de 2004. p. 19. 


\subsubsection{Duração da atividade do projeto}

A data de início da atividade do projeto foi 01/07/2004 (definida como o início da operação do sistema de coleta de gás de aterro e de geração de eletricidade). A expectativa de tempo de vida útil operacional da atividade do projeto é de 21 anos, sendo o primeiro período de abrangência de 07 anos.

\subsubsection{Plano de Monitoramento}

O Plano de Monitoramento foi desenhado a partir da escolha da tecnologia para coleta e queima do biogás, bem como da tecnologia para a geração de energia. O Plano de Monitoramento prevê o monitoramento e controle direto das reduções de emissões do projeto NovaGerar.

O biogás produzido é capturado por um sistema que simultaneamente alimenta os flares (na data de publicação do PDD o sistema de flares não estava ativo) e os geradores. Esse sistema possui aparelhos que controlam os possíveis vazamentos de biogás, as emissões de metano e a energia gerada. Os dois equipamentos - flares e geradores - operam continuamente e estão conectados a computadores que registram e armazenam os dados gerados neste processo. Um programa de computador específico calcula a energia e os créditos gerados no processo. A tecnologia utilizada permite a obtenção destes dados de 4 em 4 minutos. 
Figura 15: Quadro demonstrativo do sistema integrado de queima de biogás com geração de crédito de carbono e energia elétrica em aterro sanitário

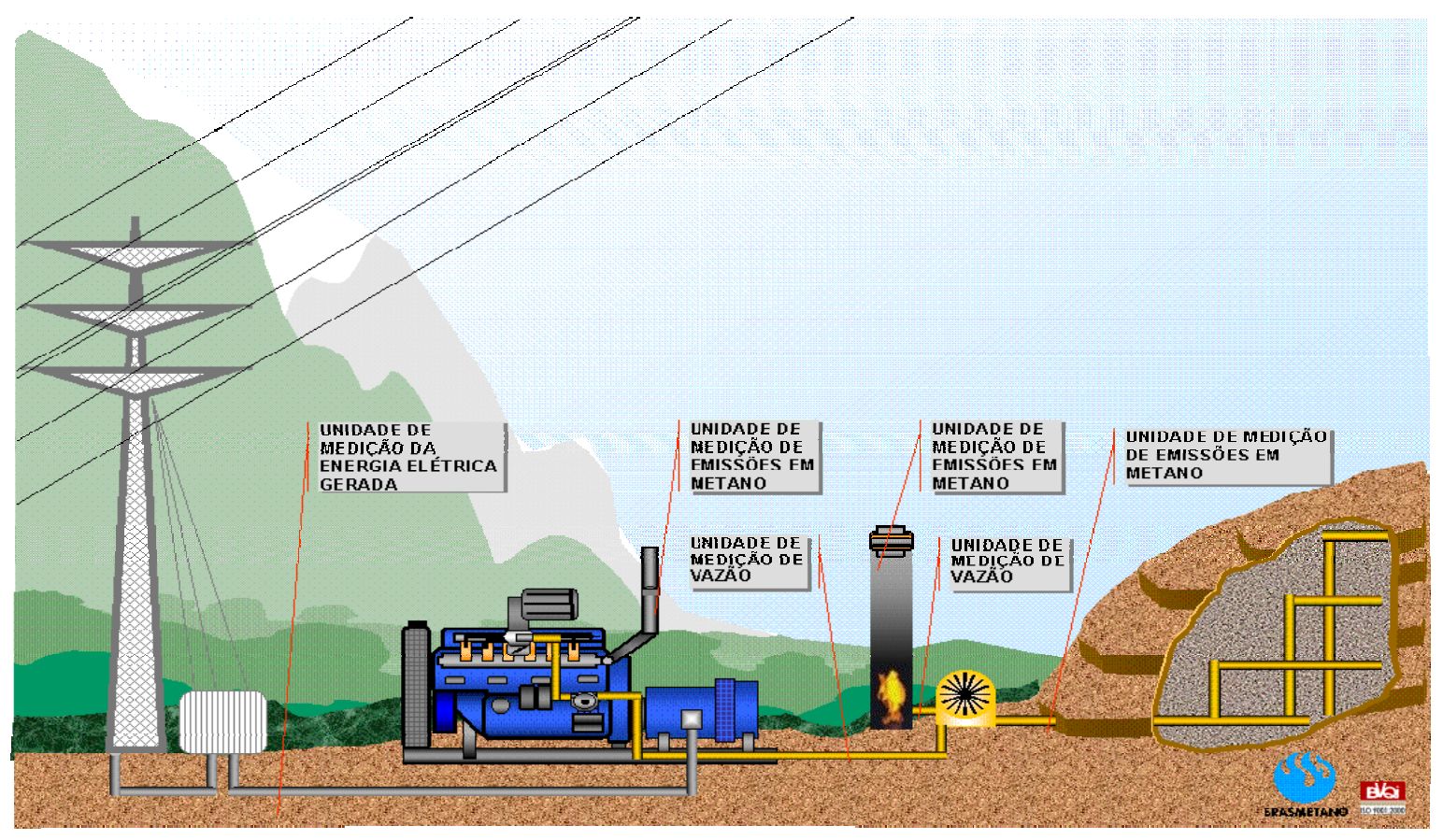

Fonte: CTR Nova Iguaçu, 2005.

Para o cálculo das reduções, o programa utiliza os dados indicados na tabela abaixo:

Tabela 9: Dados para o Plano de Monitoramento

\begin{tabular}{|c|c|c|c|c|c|c|c|c|}
\hline $\begin{array}{c}\mathrm{N}^{\circ} \text { de } \\
\text { identificação }\end{array}$ & $\begin{array}{l}\text { Variável } \\
\text { de dados }\end{array}$ & $\begin{array}{c}\text { Unidade } \\
\text { de } \\
\text { dados }\end{array}$ & $\begin{array}{c}\text { Medido(m) } \\
\text { Calculado(c) } \\
\text { Estimado(e) }\end{array}$ & $\begin{array}{l}\text { Registro } \\
\text { de } \\
\text { freqüência }\end{array}$ & $\begin{array}{c}\text { Proporção de } \\
\text { dados a ser } \\
\text { monitorada }\end{array}$ & $\begin{array}{c}\text { Como os } \\
\text { dados serão } \\
\text { arquivados }\end{array}$ & $\begin{array}{c}\text { Tempo de } \\
\text { arquivamento } \\
\text { dos dados }\end{array}$ & $\begin{array}{c}\text { Comentári } \\
\text { os }\end{array}$ \\
\hline 1 & $\begin{array}{l}\text { Fluxo de } \\
\text { gás } \\
\text { de aterro } \\
\text { para } \\
\text { queimador } \\
\text { es }\end{array}$ & $\mathrm{m}^{3}$ & M & Continuo & $100 \%$ & $\begin{array}{l}\text { Eletronicame } \\
\text { nte (planilha) }\end{array}$ & $\begin{array}{l}2 \text { anos e a } \\
\text { duração do } \\
\text { período de } \\
\text { abrangência } \\
\text { do projeto em } \\
\text { arquivos }\end{array}$ & $\begin{array}{c}\text { Os dados } \\
\text { serão } \\
\text { agregado } \\
\text { s mensal } \\
\text { e } \\
\text { anualment } \\
\text { e }\end{array}$ \\
\hline 2 & $\begin{array}{l}\text { Eletricidad } \\
\text { e bruta } \\
\text { produzida }\end{array}$ & MWh & M & Contínuo & $100 \%$ & $\begin{array}{l}\text { Eletronicame } \\
\text { nte (planilha) }\end{array}$ & $\begin{array}{c}2 \text { anos e a } \\
\text { duração do } \\
\text { período de } \\
\text { abrangência } \\
\text { do projeto em } \\
\text { arquivos }\end{array}$ & $\begin{array}{c}\text { Os dados } \\
\text { serão } \\
\text { agregado } \\
\text { s mensal } \\
e \\
\text { anualment } \\
\text { e }\end{array}$ \\
\hline 3 & $\begin{array}{l}\text { Taxa de } \\
\text { aquecime } \\
\text { nto do } \\
\text { gerador }\end{array}$ & $\begin{array}{l}\text { GJ / } \\
\text { MWh }\end{array}$ & $M \& C$ & $\begin{array}{c}\text { Determina } \\
\text { ção semi- } \\
\text { anual de } \\
\text { eficiência } \\
\text { de } \\
\text { incineraçã } \\
\text { o (se a } \\
\text { variação } \\
\text { for } \\
\text { significativ } \\
\text { a desde o } \\
\text { último } \\
\text { monitoram } \\
\text { ento, o } \\
\text { mesmo } \\
\end{array}$ & $\begin{array}{l}\text { Semi- anual ou } \\
\text { com mais } \\
\text { freqüência } \\
\text { dependendo da } \\
\text { variação } \\
\text { observada a } \\
\text { partir da } \\
\text { classificação } \\
\text { anterior }\end{array}$ & $\begin{array}{l}\text { Eletronicame } \\
\text { nte (planilha) }\end{array}$ & $\begin{array}{l}2 \text { anos e a } \\
\text { duração do } \\
\text { período de } \\
\text { abrangência } \\
\text { do projeto em } \\
\text { arquivos }\end{array}$ & $\begin{array}{c}\text { Os dados } \\
\text { serão } \\
\text { usados } \\
\text { para } \\
\text { testar e, } \\
\text { se } \\
\text { necessári } \\
\text { o corrigir } \\
\text { as } \\
\text { classificaç } \\
\text { ões das } \\
\text { placas do } \\
\text { índice } \\
\text { padrão } \\
\text { dos } \\
\end{array}$ \\
\hline
\end{tabular}




\begin{tabular}{|c|c|c|c|c|c|c|c|c|}
\hline & & & & $\begin{array}{c}\text { será } \\
\text { repetido a } \\
\text { cada mês) }\end{array}$ & & & & geradores \\
\hline 4 & $\begin{array}{c}\text { Eficiência } \\
\text { da } \\
\text { incineraçã } \\
0\end{array}$ & $\%$ & $M \& C$ & $\begin{array}{c}\text { Determina } \\
\text { ção semi- } \\
\text { anual de } \\
\text { eficiência } \\
\text { de } \\
\text { incineraçãa } \\
\text { o (se a } \\
\text { variação } \\
\text { for } \\
\text { significativ } \\
\text { a desde o } \\
\text { último } \\
\text { monitoram } \\
\text { ento, o } \\
\text { mesmo } \\
\text { será } \\
\text { repetido a } \\
\text { cada mês) }\end{array}$ & $\begin{array}{l}\text { Semi- anual ou } \\
\text { com mais } \\
\text { freqüência } \\
\text { dependendo da } \\
\text { variação } \\
\text { observada a } \\
\text { partir da } \\
\text { classificação } \\
\text { anterior }\end{array}$ & $\begin{array}{l}\text { Eletronicame } \\
\text { nte (planilha) }\end{array}$ & $\begin{array}{l}2 \text { anos e a } \\
\text { duração do } \\
\text { período de } \\
\text { abrangência } \\
\text { do projeto em } \\
\text { arquivos }\end{array}$ & $\begin{array}{c}\text { Os dados } \\
\text { serão } \\
\text { usados } \\
\text { para } \\
\text { testar e, } \\
\text { se } \\
\text { necessári } \\
\text { o corrigir } \\
\text { as } \\
\text { classificaç } \\
\text { ões de } \\
\text { eficiência } \\
\text { dos } \\
\text { queimado } \\
\text { res }\end{array}$ \\
\hline 5 & $\begin{array}{c}\text { Fração de } \\
\text { metano } \\
\text { em LFG }\end{array}$ & $\%$ & $M \& C$ & Contínuo & $100 \%$ & $\begin{array}{l}\text { Eletronicame } \\
\text { nte (planilha) }\end{array}$ & $\begin{array}{l}2 \text { anos e a } \\
\text { duração do } \\
\text { período de } \\
\text { abrangência } \\
\text { do projeto em } \\
\text { arquivos }\end{array}$ & $\begin{array}{c}\text { Os dados } \\
\text { serão } \\
\text { agregado } \\
\text { s mensal } \\
\text { e } \\
\text { anualment } \\
\text { e }\end{array}$ \\
\hline
\end{tabular}

Fonte: NOVAGERAR. Projeto de Aproveitamento do Biogás de Aterro Sanitário. Documento de Concepção do Projeto. Preparado para a Unidade de Financiamento de Carbono (PCF Prototype Carbon Fund) do Banco Mundial. Fevereiro de 2004. p. 25.

A calibração dos equipamentos de medição será feita mensalmente de acordo com as exigências do Instituto Nacional de Metrologia (INMETRO). Além disso, para garantir a qualidade dos dados monitorados, uma série de procedimentos deverá ser seguida, incluindo leituras diárias do campo de gás e do motor feitas pelo pessoal nos locais mais ativos; auditorias das rotinas diárias, semanais e mensais dos técnicos; caso haja não-conformidades detectadas pelas auditorias, estas deverão ser tratadas e verificadas em auditorias subseqüentes.

\subsubsection{Cálculos de Emissões de GEE pelas fontes}

O total de redução de emissões (em equivalente de toneladas de CO2) é o somatório dos resultados da combustão de metano em geradores e da combustão de metano em queimadores (aplicados os devidos fatores de 
conversão e GWP). A soma é, então, reduzida pelo Fator de Ajuste de Eficácia em 20\% para Marambaia, de forma a manter as estimativas conservadoras.

A captura e a combustão de metano do gás de aterro para gerar eletricidade evitará efetivamente a emissão de 14,07 milhões de toneladas de CO2 em 21 anos depois do desconto de 20\% de moderação.

No estágio atual, o projeto não requer Redução de Emissões associadas à substituição de eletricidade que de outra forma teria que ser gerada por outras usinas de energia. Portanto, nenhuma metodologia é oferecida para este componente do projeto.

Devido à natureza singular dos processos de monitoramento e de cálculo das Reduções de Emissões (por exemplo, monitoramento direto de redução de emissões), a soma descrita acima não pode ser usada diretamente para completar a tabela abaixo.

Desta forma, com base em uma variedade de pressuposições a respeito de volume e de taxas de deposições de lixo, nas tabelas a seguir são exibidos os resultados do perfil de geração de metano, a eficiência de coleta de LFG, o conteúdo de metano no LFG, a eficiência do queimador, as taxas de aquecimento do motor, entre outros fatores e as reduções de emissão projetadas. Observe que estas tabelas são apenas estimativas dos valores esperados.

Tabela 10: Resumo da linha de base e das Emissões do Projeto (em tCO2e), depois do ajuste para conservação (redução de 20\%)

\begin{tabular}{|c|c|c|c|}
\hline $\begin{array}{c}\text { Período de } \\
\text { Abrangência }\end{array}$ & $\begin{array}{c}\text { Linha de base de } \\
\text { Emissões }\end{array}$ & $\begin{array}{c}\text { Emissões do } \\
\text { Projeto }\end{array}$ & $\begin{array}{c}\text { Reduções das } \\
\text { Emissões }\end{array}$ \\
\hline 7 anos & 2.358 .500 & 353.775 & 1.895 .256 \\
\hline 10 anos & 4.339 .849 & 650.977 & 3.548 .494 \\
\hline 14 anos & 8.000 .971 & 1.200 .146 & 6.631 .322 \\
\hline 21 anos & 16.790 .727 & 2.518 .609 & 14.072 .802 \\
\hline
\end{tabular}

Fonte: NOVAGERAR. Projeto de Aproveitamento do Biogás de Aterro Sanitário. Documento de Concepção do Projeto. Preparado para a Unidade de Financiamento de Carbono (PCF Prototype Carbon Fund) do Banco Mundial. Fevereiro de 2004. p. 36. 
Tabela 11: Emissões dos cenários de linha de base e projeto para o projeto NovaGerar

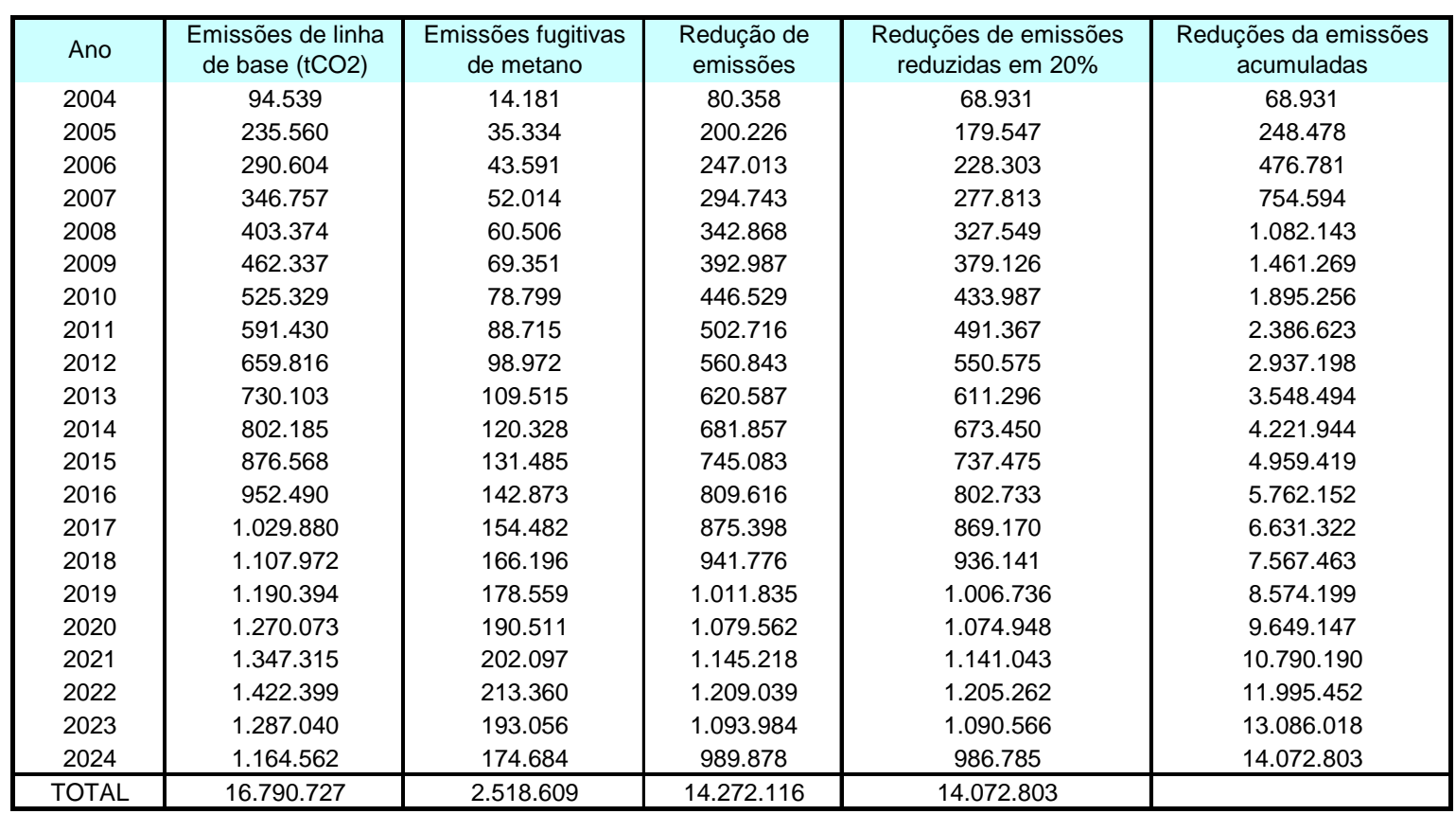

Fonte: NOVAGERAR. Projeto de Aproveitamento do Biogás de Aterro Sanitário. Documento de Concepção do Projeto. Preparado para a Unidade de Financiamento de Carbono (PCF Prototype Carbon Fund) do Banco Mundial. Fevereiro de 2004. p. 36.

\subsubsection{Impactos Ambientais}

O não gerenciamento dos resíduos e sua disposição em lixões resulta em emissões de gás de aterro (cuja principal composição é o metano), que causam efeitos ambientais globais - são GEE, portanto contribuem para o aquecimento global - e locais. As emissões de gás de aterro em espaços confinados podem causar risco de asfixia e/ou efeitos tóxicos se a concentração for elevada. Além disso, o gás de aterro pode causar odores e criação de ozônio ao nível do solo. A água do lençol freático e a água de superfície podem ser contaminadas por chorume não tratado a partir da decomposição dos resíduos no aterro.

A instalação do aterro sanitário de Adrianópolis (CTR Nova Iguaçu) e o controle do lixão de Marambaia resultarão na mitigação dos efeitos da decomposição dos resíduos e dos impactos ambientais.

Para a obtenção das licenças ambientais para a operação do aterro, a concessionária - S.A. Paulista - apresentou um Estudo de Impacto Ambiental 
(EIA-RIMA), que passou por um processo de consultas públicas e resultou em um Termo de Compromisso com o Ministério Público, do qual destaca-se o fechamento e recuperação do lixão de Marambaia. Causa estranheza a localização da CTR em meio a uma área de mata fechada, fato que não foi explicado pela S.A. Paulista quando do questionamento.

\subsubsection{Comentários das Partes Interessadas (Stakeholders)}

O processo de consulta das Partes Interessadas para o projeto NovaGerar incluiu opiniões sobre o lixão de Marambaia e o aterro de Adrianópolis e foi realizado pela Associação Brasileira de Engenharia Sanitária e Ambiental (ABES) - organização independente especializada em questões de engenharia sanitária e ambientais.

O processo de consulta às partes interessadas utilizou questionário específico e dividiu o público de interesse em 5 grupos: representantes do setor público (inclusive agências ambientais, prefeituras, governos estadual e federal e universidades locais); organizações não-governamentais (ONGs); representantes do setor privado (fornecedor de energia elétrica e distribuidor de gás local); a organização internacional de alteração do clima (IETA); e catadores.

Segundo o caso de estudo LFG to Energy Project in Nova Iguaçu, Brazil produzido pelo consultor do Banco Mundial, J.H. Penido Monteiro, inicialmente foram contatadas 34 entidades, das quais uma preferiu não fazer declarações sobre o assunto e 14 não responderam ao questionário. Depois de selecionar novas entidades do setor público e dos lixeiros, 25 questionários foram aplicados, sendo distribuídos da seguinte forma: 11 representantes do setor público, 3 de ONGs, 2 do setor privado, 2 de organizações internacionais e 7 representantes dos catadores.

Todas as organizações consultadas concordaram com o projeto e a maioria delas destacou a importância do aterro dada a situação precária da disposição de lixo no Brasil e em particular na Região Metropolitana do Rio de Janeiro. Destacamos alguns comentários dos entrevistados: 
"Os beneficiários do projeto serão, na maioria, a população e a sociedade, e a maior contribuição do projeto será o esforço global de luta contra as mudanças climáticas - representantes do setor público". (tradução da autora) $)^{80}$

"O fator ambiental e socioeconômico mais importante será a qualificação/geração de conhecimento objetivando a melhoria da qualidade de vida e do meio ambiente - ONGs". (tradução da autora) ${ }^{81}$

"O relativo aumento do número de empregos será a maior vantagem para a infra-estrutura ambiental resultante da implementação de um projeto desta dimensão - catadores" (tradução da autora). ${ }^{82}$

"A criação de um modelo de energia renovável e sua expansão para outras regiões aumenta a possibilidade de integração regional e articulação com outros setores - representante do setor privado". (tradução da autora) $^{83}$

"As maiores vantagens para a infra-estrutura local/ambiental resultantes da implementação do projeto serão a criação de empregos e a contribuição para a redução do efeito estufa - organizações internacionais". (tradução da autora) ${ }^{84}$

$\mathrm{Na}$ opinião das Partes Interessadas consultadas, o projeto contribui para a geração de benefícios sociais e ambientais, de escalas local e global. Socialmente, os mais impactados pelo projeto serão os catadores que trabalhavam no lixão de Marambaia, que de acordo com as premissas do projeto

\footnotetext{
${ }^{80}$ The project beneficiaries will be, in the majority, the population and the society and the greatest contribution of the project will be the global effort to fight against the climatic change. In: MONTEIRO, J. H. Penido. Case Study: LFG to Energy Project in Nova Iguaçu, Brazil. Inception Report and Expanded Outline. September, 2003. p. 69.

${ }^{81}$ The most important environmental social-economical factor will be the qualification/generation of knowledge aiming the quality of life/environment improvement. In: MONTEIRO, J. H. Penido. Case Study: LFG to Energy Project in Nova Iguaçu, Brazil. Inception Report and Expanded Outline. September, 2003. p. 70.

${ }^{82}$ The relative increase in jobs will be the greatest advantage for the environmental infrastructure resulting from the implementation of a project of that dimension. In: MONTEIRO, J. H. Penido. Case Study: LFG to Energy Project in Nova Iguaçu, Brazil. Inception Report and Expanded Outline. September, 2003. p. 71.

${ }^{83}$ The creation of an energy recycling model and its expansion to other regions increase the possibility of regional integration and the articulation to other segments. In: MONTEIRO, J. H. Penido. Case Study: LFG to Energy Project in Nova Iguaçu, Brazil. Inception Report and Expanded Outline. September, 2003.p. 72.

${ }^{84}$ The greatest advantages for the local/environmental infrastructure resulting from the project implementation will be the increase in local jobs and the contribution in reducing the greenhouse effect. In: MONTEIRO, J. H. Penido. Case Study: LFG to Energy Project in Nova Iguaçu, Brazil. Inception Report and Expanded Outline. September, 2003. p.. 73.
} 
serão absorvidos pela operadora do aterro e por outros projetos a serem implementados pelo poder público.

\subsubsection{Validação}

A validação do Project Design Document (PDD) do Projeto de Aproveitamento do Biogás de Aterro Sanitário - NovaGerar, preparado para o Prototype Carbon Fund do Banco Mundial foi feita pela Entidade Operacional Designada Det Norske Veritas (DNV).

O processo de validação do projeto se iniciou em novembro de 2002 e foi concluído em fevereiro de 2004. A validação consistiu de três fases: i) revisão específica da concepção do projeto, da metodologia de linha de base e do plano de monitoramento (Dez/2002 a Fev/2004); ii) acompanhamento das entrevistas com as partes interessadas do projeto (Fev/2003) e iii) resolução de questões pendentes e parecer da versão final do relatório de validação e opiniões (Fev/2003 a Fev/2004).

A metodologia de linha de base e de monitoramento foram desenvolvidas especificamente para o projeto NovaGerar. De acordo com as regras do Comitê Executivo, antes de uma submissão para registro das atividades de projeto de MDL, a EOD deve encaminhar ao conselho executivo, para revisão, a metodologia proposta, juntamente com o documento preliminar de concepção do projeto, incluindo uma descrição do projeto e a identificação dos seus participantes. O conselho executivo deve, de forma expedita, se possível em sua próxima reunião, mas no prazo máximo de quatro meses, rever a nova metodologia proposta, de acordo com as modalidades e os procedimentos. Tendo aprovado a nova metodologia, o conselho executivo deve torná-la pública, juntamente com qualquer orientação pertinente, e a entidade operacional designada pode continuar com a validação da atividade de projeto e submeter o documento de concepção do projeto para registro.

Em abril de 2003 a metodologia de linha de base e o plano de monitoramento foram submetidos ao Painel Metodológico do Conselho Executivo para revisão. O Comitê Executivo solicitou que algumas alterações fossem feitas 
na metodologia de linha de base, dentre as quais destacamos a necessidade de especificar o Fator de Ajuste de Eficácia (FAE) do projeto e como era determinado. A recomendação do Painel Metodológico foi de que o FAE fosse estabelecido em 20\% para Marambaia, de forma a manter as estimativas conservadoras.

Feitas as alterações solicitadas, a metodologia foi novamente submetida ao Comitê Executivo em julho de 2003 e aprovada em outubro de 2003.

Após a aprovação da metodologia de linha de base e monitoramento, e de sua publicação no website do MDL, o PDD foi finalizado e novamente submetido à DNV, que em 29 de março de 2004 emitiu a seguinte opinião de validação:

“(...) A determinação da linha de base está bem elaborada, evidente, suficientemente suportada com fatos e, portanto, razoável para os primeiros 07 anos do período de creditação de 2004-2010. Além disso, uma análise econômica da atratividade do projeto, sem a renda dos créditos de carbono demonstra que o projeto não é um provável cenário bussiness as usual. É provável que o projeto mitigue as emissões de GEE mediante a) coleta e combustão ou queima do gás de aterro sanitário (LFG) captado nos aterros sanitários de Marambaia e de Adrianópolis e b) geração de eletricidade produzida por combustível fóssil sendo parcialmente substituída pelo LFG. No entanto, as reduções potenciais de emissão em decorrência do fornecimento de eletricidade para a rede regional não serão reivindicadas pelo projeto. O projeto resulta em redução de emissões de $\mathrm{CH} 4$ que sejam reais, mensuráveis e com benefícios de longo prazo e que sejam adicionais ao que teria ocorrido na ausência do projeto.

Os cálculos de emissão de GEE estão documentados de maneira completa e evidente. O algoritmo e as metodologias para a contagem de emissões de GEE são apropriadas e os fatores de emissão são considerados, de modo geral, como sendo de suficiente exatidão. Os valores utilizados para o GWP para o metano e para a eficácia da coleta de gás não são vistos como conservadores. Portanto, o projeto pode resultar em menos ERs do que o estimado.

Através da coleta e combustão do gás de aterro sanitário, o projeto irá reduzir emissões não controladas de metano e contribuirá para 
a redução de riscos ambientais e de saúde, assim como de potencial para explosões. O projeto doará aproximadamente $10 \%$ da eletricidade gerada no local para a prefeitura.

O projeto NovaGerar está adequado com as políticas de desenvolvimento sustentável no Brasil.

Resumindo, é da opinião da equipe de validação que o "Projeto de Aproveitamento de Gás de Aterro Sanitário - NovaGerar", como descrito na versão revisada de fevereiro de 2004 do documento de concepção do projeto, cumpre com todos requerimentos relevantes da UNFCCC para o MDL e com todos os critérios relevantes do país hospedeiro. No entanto, o projeto ainda não obteve aprovação escrita da Autoridade Nacional Designada Brasileira, incluindo uma confirmação de que o projeto contribui para o desenvolvimento sustentável. Seguido do endosso pela AND Brasileira e da segunda consulta às partes necessária, o "Projeto de Aproveitamento de Gás de Aterro Sanitário - NovaGerar" será recomendado pela DNV Certificações para registro no MDL." ${ }^{85}$

A emissão da validação favorável pela EOD representa uma etapa muito importante, pois atesta que o projeto é passível de reduzir emissões de GEE e está de acordo com as premissas do Protocolo de Kyoto.

\subsubsection{Aprovação pela Autoridade Nacional Designada}

O PDD do projeto NovaGerar, bem como a validação pela Entidade Operacional Designada foram submetidos a apreciação da Autoridade Nacional Designada (AND), que no caso do Brasil é a Comissão Interministerial de Mudança do Clima, em 30 de março de 2004.

A Comissão Interministerial deve avaliar o relatório de validação e a contribuição do projeto para o desenvolvimento sustentável do país, considerando os seguintes aspectos: distribuição de renda, sustentabilidade ambiental local, desenvolvimento das condições de trabalho e geração líquida de emprego,

${ }^{85}$ Det Norske Veritas - Relatório de Validação. Prototype Carbon Fund. Validação do gás de aterro sanitário de NovaGerar para o projeto de energia, Brasil. Relatório n 2003-0221. Disponível em : http://www.mct.gov.br/index.php/content/view/16045.html, consultado em 25/04/2007. 
capacitação e desenvolvimento tecnológico, e integração regional e articulação com outros setores.

Em 02 de junho de 2004, a AND publicou junto ao Comitê Executivo a carta de aprovação considerando que o projeto NovaGerar contribuirá para o desenvolvimento sustentável do país. A carta explicitou ainda que o projeto estava pronto para a solicitação pela EOD do registro do projeto como uma atividade de MDL.

A Autoridade Nacional Designada do governo dos Países Baixos, para o qual os certificados de emissões reduzidas serão vendidos também aprovou 0 projeto em 31 de agosto de 2004.

\subsubsection{Submissão ao Conselho Executivo para Registro}

A EOD solicitou o registro junto ao Comitê Executivo da Concenção no dia 18 de novembro de 2004 apresentando os seguintes documentos:

- Formulário de Registro de projeto de MDL para Gás de aterro sanitário de NovaGerar para o projeto de energia, Brasil;

- PDD - versão de fevereiro de 2004;

- Plano de monitoramento - versão de fevereiro de 2004;

- Carta de aprovação da AND de 02 de junho de 2004;

- Declaração de aprovação e carta de autorização do International Bank for Reconstruction and Development (IBRD), o trustee do World Bank Netherlands Clean Development Facility (WB NCDF), pela AND dos Países Baixos de 31 de agosto de 2004;

- Relatório de validação de 03 de setembro de 2004 da DNV;

- Uma indicação assinada por todas as partes integrantes do projeto estipulando as modalidades de comunicação com o Comitê Executivo e o secretariado, em particular com relação às instruções sobre emissões de CERs;

- Informações bancárias sobre o pagamento da taxa de registro do projeto. 
O projeto NovaGerar foi o primeiro do mundo a ser registrado no Comitê Executivo da ONU no Mecanismo de Desenvolvimento Limpo, assinalando a efetiva entrada em vigor do mercado de créditos de carbono.

\subsubsection{Monitoramento}

O Plano de Monitoramento, aprovado pelo Painel Metodológico (AM0003), que inclui o recolhimento e armazenamento de todos os dados necessários para calcular a redução das emissões de GEE, vem sendo aplicado desde o início do funcionamento da CTR Nova Iguaçu, como sendo uma obrigação de cálculo das emissões de GEE durante todo o processo de instalação do empreendimento. Porém, somente a partir de março de 2007 é que o Plano de Monitoramento do projeto NovaGerar especificamente, teve início, pois a queima pelos flares, conforme descrito no PDD passou a ser utilizada. O Plano de Monitoramento deverá ser aplicado durante toda a vida útil do projeto e os dados coletados serão utilizados para o cálculo dos CERs.

\subsubsection{Verificação/Certificação}

A partir do levantamento dos dados para o cálculo das reduções das emissões de GEE, terá início o processo de verificação, que consiste em auditorias periódicas e independentes para revisar os cálculos acerca das emissões de GEE. Esse processo tem o intuito de verificar se as reduções realmente aconteceram. O WB NCDF será responsável por escolher a verificadora e acompanhar todo o processo de auditoria.

A verificação inicial do projeto NovaGerar será conduzida pela certificadora SGS, que fará auditoria nos dados do primeiro semestre de implementação do Plano de Monitoramento, portanto de março a setembro de 2007. As auditorias podem ser realizadas a cada solicitação de créditos, portanto podem ser semestrais, anuais ou mesmo em períodos maiores, pois o custo para a verificação é alto e deve ser pago pelo solicitante dos CERs.

Segundo informações do gerente de projetos da NovaGerar, serão adotadas auditorias semestrais para a verificação das reduções de emissões. As 
auditorias não serão feitas somente pela SGS, mas também por outras empresas, o que garantirá credibilidade às informações de reduções.

\subsubsection{Emissão dos CERs}

Cumpridas todas as etapas do projeto e provadas que as reduções de emissões de GEE são reais, mensuráveis e de longo prazo, são originadas as CERs. As CERs são emitidas pelo Comitê Executivo e serão creditadas aos participantes do projeto, no caso do NovaGerar à S.A. Paulista e ao World Bank Netherlands Clean Development Facility.

De acordo com o PDD, o projeto NovaGerar deverá gerar de 2004 a 2024 uma redução total de 14.072.802 toneladas de CO2e. Os créditos de carbono negociados com o governo dos Países Baixos referem-se ao período de 2004 a 2012, com o valor de € 3,35 por crédito de carbono.

Os CERs do projeto NovaGerar ainda não foram emitidos pois ainda não houve verificação das reduções de emissões.

Ao longo do desenvolvimento do projeto, o governo dos Países Baixos fez adiantamentos no valor de 1,5 milhões de euros para compra de equipamentos do aterro, deduzindo do valor total previsto de 13,5 milhões. $O$ governo dos Países Baixos conseguiu, dessa forma, negociar um valor baixo para a compra dos créditos de carbono (que em 2007 é negociado em torno de US\$ 10,90), pois com a dúvida quanto a entrada em vigor do Protocolo de Kyoto e a não instauração do mercado, os investimentos representavam um risco. Os CERs comprados servirão para deduções da meta de redução estabelecida aos Países Baixos.

Como é esperado pela NovaGerar que o valor dos créditos aumente no mercado internacional, pode-se vender os CERs de carbono futuras (geradas de 2013 até 2022).

\subsection{Benefícios socioambientais do projeto NovaGerar}

A implantação da CTR Nova Iguaçu e do projeto NovaGerar possibilitou a mitigação de impactos ambientais e a geração de benefícios sociais. 
No Brasil, segundo dados do IBGE, conforme já assinalado anteriormente, $63,6 \%$ dos resíduos produzidos diariamente no país têm como destinação final os lixões. Os lixões não têm os pré-requisitos necessários à mitigação dos impactos ambientais decorrentes da decomposição da matéria orgânica, que gera chorume e biogás - responsáveis pela contaminação do solo, das águas superficiais, dos lençóis freáticos e aumento do efeito estufa.

No país, os lixões são os locais de trabalho de muitas pessoas, que excluídas do mercado de trabalho formal, passam a coletar materiais recicláveis para sobreviver. Essa é uma prática degradante, pois condena trabalhadores a sobreviverem dos rejeitos da sociedade.

A licitação pública da prefeitura de Nova Iguaçu para a concessão dos serviços de tratamento e disposição final dos resíduos sólidos domiciliares e públicos da cidade previa, além da construção da Central de Tratamento de Resíduos, o fechamento e remediação do passivo ambiental gerado pela disposição de resíduos no lixão de Marambaia durante 13 anos.

A vencedora da licitação, a empresa S.A. Paulista, promoveu o fechamento do lixão, e está implementando tratamento do chorume, reciclagem de óleos e combustíveis, controle de incêndios com a instalação de equipamentos para a drenagem do biogás e encaminhamento para a central de geração de energia, proibição de caça e corte de árvores nos local, trabalhos de recobrimento do lixo e recuperação paisagística.

$\mathrm{Na}$ época do fechamento do lixão, cerca de 89 catadores sobreviviam da renda gerada pela coleta de materiais no local. Esses catadores trabalhavam sem os devidos equipamentos de segurança (tais como luvas, botas ou máscara), usando apenas calça comprida e sapato fechado. As condições de trabalho eram indignas, como falta de banheiro, água para beber, espaço para realizar refeições ou descansar do sol.

Com o encerramento da disposição de resíduos no lixão, parte destes catadores foram contratados pela CTR Nova Iguaçu para cuidarem do viveiro instalado no interior do empreendimento, que produz mudas de espécies da Mata Atlântica utilizadas na cobertura de áreas degradadas e enriquecimento vegetal. Alguns foram absorvidos por empresas que prestam serviços à prefeitura e outros passaram a trabalhar na cooperativa de reciclagem construída pela prefeitura que 
recebe os materiais provenientes da coleta seletiva do município. O fechamento do lixão representou uma melhoria nas condições de trabalho e dignidade dos excatadores, incluindo-os no mercado formal de trabalho e proporcionando melhores condições de sobrevivência.

A instalação de um sistema de tratamento de chorume, que inclui o monitoramento do lençol freático e das águas superficiais; a reciclagem de óleos combustíveis, que são coletados, armazenados e levados para reciclagem; a instalação de equipamentos para drenagem de biogás que é direcionado para os geradores e com isso evitam incêndios, além de diminuírem o impacto causado pela emissão de metano diretamente para a atmosfera; a proibição da caça e do corte de árvores, garantido pela presença da equipe de segurança 24 horas por dia no local; o recobrimento do lixo, bem como o enriquecimento vegetal da área com espécies da Mata Atlântica, serão responsáveis pela remediação do passivo gerado pela disposição inadequada dos resíduos. Todos estes procedimentos, se cumpridos corretamente, proporcionarão a mitigação dos impactos ambientais no local e proporcionarão o estabelecimento da planta de energia limpa e da área de lazer para a comunidade, previstos no projeto de recuperação do local.

A instalação da Central de Tratamento de Resíduos de Nova Iguaçu proporciona o gerenciamento dos resíduos sólidos e a correta disposição dos mesmos, tendo em vista que um aterro sanitário deve ter impermeabilização de base do terreno, proteção por manta de PEAD, além de drenagem de chorume e biogás. Todos esses pré-requisitos diminuem os impactos ambientais pela disposição dos resíduos.

A CTR Nova Iguaçu foi licenciada pelos órgãos ambientais competentes e instalada seguindo os pré-requisitos citados acima.

A instalação da drenagem de chorume, que é tratado na Unidade de Tratamento de Percolados garante a não contaminação das água superficiais e do lençol freático.

O biogás gerado no aterro é também aproveitado na produção de energia limpa que move os evaporadores da Unidade de Tratamento de Percolados. O processo de captação e drenagem do biogás é feito por meio de drenos onde o gás é canalizado por tubulações de PEAD, conduzido a dois equipamentos específicos e, então succionado para o conjunto de evaporadores. Esses 
equipamentos asseguram a evaporação da água do chorume e a sedimentação de sólidos no interior da câmara que posteriormente são depositados no aterro.

O biogás também é destinado a equipamentos de queima controlada, os chamados flares, que fazem a combustão do metano transformando-o em dióxido de carbono. Esses dois processos garantem a redução das emissões de metano diretamente na atmosfera, contribuindo para a mitigação do efeito estufa. Portanto, são ações de melhoria local que resultam em um impacto positivo na escala global.

A implantação do viveiro possibilita a produção de mudas nativas da Mata Atlântica, que são utilizadas no enriquecimento vegetal do entorno do aterro de Adrianópolis e na recuperação do lixão de Marambaia. O plantio de mudas nativas reduz os impactos das operações e contribui para o aumento da biodiversidade local, além de proporcionarem o seqüestro de carbono.

A construção da CTR contribuiu relativamente com a geração de empregos durante a execução do empreendimento, além daqueles criados em função do funcionamento da CTR.

A instalação do centro de educação ambiental proporciona a disseminação do conhecimento sobre as questões ambientais à comunidade.

O conhecimento gerado e o pioneirismo brasileiro na elaboração do projeto de MDL são fatores importantes a serem considerados, pois a estrutura constituída para a CTR e o projeto de redução de GEE podem ser um modelo replicável para outros municípios do país, contribuindo para a mitigação de impactos ambientais locais e globais.

O aumento da consciência de que os recursos naturais são limitados tem provocado uma mudança de paradigma nas ações antrópicas. Mudança lenta é claro, mas mecanismos econômicos ligados a esses paradigmas poderão acelerar o processo. Os projetos de MDL são um exemplo disso, pois abrem a perspectiva de financiamentos em Países Não Anexo I. Países estes, que não são historicamente responsáveis, mas que hoje também contribuem de forma significativa com os totais das emissões de GEE mundiais. O Brasil, por exemplo, é o terceiro maior emissor de GEE, posição alcançada pelos altíssimos índices de desmatamento. Posição que coloca o país sob a pressão de ter que assumir metas no período pós-2012. 
A principal questão que envolve os projetos de MDL é a possibilidade de implementarem mudanças no modelo de desenvolvimento. A CTR Nova Iguaçu e do projeto NovaGerar possibilitaram a mitigação de impactos ambientais e a geração de benefícios sociais. Esse modelo pode ser uma solução para a resolução de problemas socioambientais, portanto, replicável para outros municípios do país, promovendo melhorias locais e globais. 


\section{CONSIDERAÇÕES FINAIS}

O modelo de desenvolvimento adotado principalmente após a Revolução Industrial por países desenvolvidos e pelos novos países industrializados gerou impactos ambientais que se sobrepõem aos limites territoriais dos Estados.

A exploração desenfreada dos recursos naturais e suas conseqüências tornaram-se evidentes a partir do século $\mathrm{XX}$. Os problemas relacionados à questão ambiental suscitou estudos e discussões em escala mundial a respeito da ação antrópica, visto que os resultados colocam em risco a segurança ambiental.

As tensões originadas da degradação ambiental podem legitimar determinadas relações sociais que abrangem, inclusive, o conflito direto por recursos naturais. Para que a situação não chegue a esse ponto, é necessário conciliar os interesses dos Estados visando à garantia da segurança ambiental.

A combinação de interesses resulta em políticas e negociações, que são traduzidas em regulamentações. No cenário internacional ela resulta em Convenções e Tratados acerca de inúmeras questões ambientais, tais como a Convenção sobre Biodiversidade, a Convenção Quadro das Nações Unidas sobre Mudanças Climáticas, a Convenção sobre Poluição Transfronteiriça. Esse acordos visam a "diminuir" os impactos causados pela espécie humana no meio ambiente, estabelecendo como meta o polêmico desenvolvimento sustentável

A Convenção Quadro sobre Mudanças Climáticas é um claro exemplo dessa convergência de interesses, pois os estudos realizados pelo IPCC têm evidenciado a interferência antrópica no sistema climático (por meio das emissões de GEE) e as desastrosas conseqüências para a sobrevivência na Terra. Essas conseqüências incluem, por exemplo, a elevação dos níveis dos oceanos, que condenará milhares de pessoas que vivem nas regiões costeiras a migrarem para o interior do continente. Essa migração resultará em precária infra-estrutura para o atendimento das necessidades básicas da população, escassez de água e alimentos, conflitos pela terra. A convergência dos interesses dos Estados em prevenir e reverter os impactos do aquecimento global resultaram no estabelecimento da Convenção. 
A Convenção destaca que os países desenvolvidos foram e são os principais responsáveis pelas emissões de gases de efeito estufa, estabelecendo, portanto, o princípio das responsabilidades comuns, porém diferenciadas. Assim, cabe a eles estar à frente do esforço por reverter a situação. Os países com os maiores índices de emissões de gases de efeito estufa foram reunidos no Anexo I e a eles coube o compromisso de manter o volume de emissões de 1990 a partir do ano 2000.

As Conferências das Partes da Convenção de Mudanças Climáticas (COP) tiveram início em 1995, com a COP1, com um grande desafio: buscar o entendimento entre os Estados para que o objetivo final da Convenção fosse atingido, tendo em vista os interesses difusos. Na COP 1 discutiu-se a criação de um "protocolo ou de algum instrumento legal" para o controle da emissão dos gases de efeito estufa. Depois de dois anos e meio de negociações intensas, o Protocolo de Kyoto foi adotado na COP 3 no dia 11 de dezembro de 1997.

No Protocolo de Kyoto, as Partes do Anexo I comprometem-se com metas individuais de redução de suas emissões de gases de efeito estufa, que representam um corte total de pelo menos 5\% em relação aos níveis de 1990 no período de 2008-2012.

O Protocolo é um instrumento inovador, pois impõe aos países metas de redução de GEE, que para serem atingidas, "obrigatoriamente" resultam em uma mudança de paradigma. Os projetos de seqüestro de carbono, por exemplo, induzem a conservação das florestas. A captura do metano pressupõe o correto gerenciamento dos resíduos.

Além disso, o Protocolo influenciou a ordem ambiental internacional, pois cada país se posiciona em relação às regulamentações de acordo com seus interesses. Os Estados Unidos, por exemplo, cuja base energética é composta por combustíveis fósseis - o que em primeiro lugar no ranking dos maiores emissões de GEE do mundo - não ratificou o Protocolo. A adesão ao Protocolo pressuporia uma drástica mudança no modelo de desenvolvimento adotado, o que não é interessante para o país.

O Protocolo estabeleceu três mecanismos financeiros inovadores, dos quais destacamos o Mecanismo de Desenvolvimento Limpo, iniciativa proposta pelo governo brasileiro durante as discussões das Conferências das Partes, que 
prevê financiamentos de países pertencentes ao Anexo I, em países Não Anexo I, como é o caso do Brasil, China e Índia.

Os financiamentos propostos pelo MDL prevêem cooperações em diversos segmentos que resultem nos chamados Certificados de Emissões Reduzidas (ou créditos de Carbono) aos países do Anexo I, que seriam utilizados para atingir as metas de redução exigidas.

O Brasil não faz parte do Anexo I, e neste primeiro período de reduções não necessita cumprir metas. Dessa forma, o MDL surge como uma ótima oportunidade de captação de recursos.

O primeiro projeto de MDL registrado e validado em âmbito mundial pela Convenção Quadro é o brasileiro NovaGerar, desenvolvido na cidade de Nova Iguaçu no Rio de Janeiro.

A base para a implantação do projeto NovaGerar é resultado da instalação do aterro sanitário (CTR Nova Iguaçu) em Adrianópolis. O projeto visa a aproveitar o biogás gerado pela decomposição dos resíduos depositados no aterro e consequentemente reduzir as emissões de metano. Os créditos de carbono gerados pelo projeto de 2004 a 2012 serão adquiridos pelo governo dos Países Baixos por meio do por meio do Banco Mundial, que obteve vantagem na negociação do valor do crédito, pois a insegurança quanto a entrada em vigor do Protocolo resultou na negociação de valor muito abaixo do negociado hoje.

A implantação do aterro sanitário de Adrianópolis possibilitou o adequado gerenciamento dos resíduos sólidos e a possibilidade da implementação de um projeto de MDL.

O Brasil não tem uma política nacional para o gerenciamento dos resíduos sólidos, dessa forma o modelo utilizado pela CTR Nova Iguaçu, resultado de uma parceria entre a prefeitura e o setor privado, pode ser uma opção para que os resíduos gerados pela população sejam corretamente dispostos, mitigando os impactos ambientais e sociais decorrentes dessa atividade.

Esse modelo pode ser adotado por inúmeros municípios do país que ainda fazem a disposição dos resíduos em lixões, promovendo melhorias locais que têm reflexo em escala global.

A captação do metano e sua conversão em energia ou queima por flares, resultam na redução de emissões de um dos gases com maior potencial de 
aquecimento global, contribuindo dessa forma para a minimização do efeito estufa. Portanto, o gerenciamento dos resíduos, em nível local, acarretam melhorias em escala global.

Neste primeiro período de compromisso do Protocolo de Kyoto, no qual o Brasil não tem metas de redução a cumprir, seria oportuno investir em projetos de MDL em aterros sanitários, para os quais há um fator preponderante: a metodologia já está aprovada, o que facilita o trâmite do projeto no Comitê Executivo (tendo em vista que os processo são muito longos e ainda há inúmeras dúvidas quanto a aprovação das metodologias), além do modelo já em desenvolvimento - NovaGerar.

Entretanto, não é só este tipo de projeto que poderia captar recursos financeiros para o Brasil, o desenvolvimento de projetos de seqüestro de carbono pelo reflorestamento e florestamento também seria uma oportunidade para contrabalancear as emissões causadas pelo desmatamento. Projetos de biocombustíveis e de pequenas centrais hidrelétricas também abrem oportunidades de captação de recursos.

O Brasil é um dos maiores emissores de GEE do mundo, colocação alcançada principalmente pelo desmatamento na Amazônia. Grande parcela da população é formada por pobres que seriam os mais atingidos por eventos climáticos. Dessa forma não é admitido o imobilismo diante do cenário atual. É necessário imprimir forças e desenhar estratégias para a promoção de um desenvolvimento que garanta a base material para a reprodução da vida. 


\section{REFERÊNCIAS}

ARON, R. Paz e guerra entre as nações. Brasília: Universidade de Brasília, 1986.

BRASIL. Ministério da Ciência e Tecnologia. Protocolo de Kyoto - Texto editado e traduzido pelo Ministério da Ciência e Tecnologia com apoio do Ministério das Relações Exteriores da República Federativa do Brasil.1997. Disponível em: http://www.mct.gov.br/index.php/content/view/28739.html. Acessado em 22/11/2006.

Ministério da Ciência e Tecnologia. Status atual das atividades de projeto no âmbito do Mecanismo de Desenvolvimento Limpo (MDL) no Brasil e no mundo. Documento publicado pelo Ministério da Ciência e Tecnologia. Disponível em: http://www.mct.gov.br/index.php/content/view/30317.html 07/05/2007.

Acessado em

Ministério da ciência e tecnologia. Texto da Convenção-Quadro das Nações Unidas sobre Mudança do Clima. Editado e traduzido pelo Ministério da Ciência e Tecnologia com o apoio do Ministério das Relações Exteriores da República Federativa do Brasil. Anexo I. Disponível em: http://www.mct.gov.br/index.php/content/view/4120.html. Acessado em 22/11/2005.

Ministério da Ciência e Tecnologia. Decisão 1/CP.3 - Adoção do Protocolo de Quioto à Convenção-Quadro das Nações Unidas sobre Mudança do Clima. Disponível em: http://www.mct.gov.br/index.php/content/view/18789.html?, Acessado em 02/05/2007.

Ministério da Ciência e Tecnologia. Inventário de Emissões e Remoções Antrópicas de Gases de Efeito Estufa não controlados pelo Protocolo de Montreal Comunicação Inicial do Brasil. 2005. http://www.mct.gov.br/index.php/content/view/17351.html. Acessado em 20 de abril de 2007.

Ministério da Ciência e Tecnologia. KYOTO PROTOCOL. Status of ratification. Disponível em: http://www.mct.gov.br/index.php/content/view/4457.html._Acessado em 11/05/2007.

COMISSÃO MUNDIAL PARA O MEIO AMBIENTE E DESENVOLVIMENTO. Nosso Futuro Comum. Rio de Janeiro, FGV, 1991.

DERANI, Cristiane. Direito Ambiental Econômico. São Paulo. Max Limonad, 2001.

DET NORSKE VERITAS.. Validação do gás de aterro sanitário de NovaGerar para o projeto de energia, Brasil. Prototype Carbon Fund. Relatório de Validação $\mathrm{n}^{\circ}$ 2003-0221. Disponível em 
http://www.mct.gov.br/index.php/content/view/16045.html, 25/04/2007.

DINIZ, Eliezer Martins. Os resultados da Rio+10. In: Revista do Departamento de Geografia. 15 (2002).

ELLIOTT, L. The Global Politics and Environment. Macmillan, 1998.

FELIPETTO, Adriana V. Montenegro. Avaliação de Concessionária de Tratamento de Resíduos com Opções Reais. Dissertação de Mestrado.Rio de Janeiro: Faculdades Ibmec, 2005.

GALVÃO, L.C.R.; GRIMONI, J.A.B.; UDAETA, M.E.M. (Org.) Iniciação a Conceitos de sistemas Energéticos para o Desenvolvimento Limpo. - São Paulo: Editora da Universidade de São Paulo, 2004.

IBGE. Pesquisa nacional de saneamento básico 2000. Rio de Janeiro: 2002.

IPCC. Climate Change 2001: Synthesis Report. Summary for Policymakers. A Report of Working Group I of the IPCC.

Climate Change 2007: Climate Change Impacts, Adaptation and Vulnerability. Summary for Policymakers. Disponível em: http://ipccwg1.ucar.edu/wg1/wg1-report.html. Acessado em 05/02/2007.

. Climate Change 2007: The Physical Science Basis. Disponível em: http://www.ipcc.ch/SPM2feb07.pdf -página 07. Acessado em 05/02/2007.

16 Years of Scientific Assessment in Support $f$ the Climate Convention. December 2004.

IPT/CEMPRE - Instituto de Pesquisas Tecnológicas; Compromisso Empresarial para Reciclagem. Lixo Municipal - Manual de Gerenciamento Integrado. 2a edição. Página \& Letras, 2000.

LE PRESTRE, Philippe. Ecopolítica Internacional. São Paulo, SENAC, 2000.

LEFF, Enrique. Epistemologia Ambiental. São Paulo: Cortez, 2002.

MIGUEZ, José Domingos Gonzales. A Mudança Global do Clima: Perspectivas pós Bonn. Disponível em: http://www.mct.gov.br/index.php/content/view/21403.html - c consultado em $\underline{11 / 05 / 2007 .}$.

MIGUEZ, José Domingos González. O Mecanismo de Desenvolvimento Limpo: a proposta e as perspectivas brasileiras. Trabalho apresentado no evento "Sustentabilidade na Geração e Uso da Energia no Brasil: os Próximos Vinte Anos. Unicamp, 2002. 
MONTEIRO, J. H. Penido. Case Study: LFG to Energy Project in Nova Iguaçu, Brazil. Inception Report and Expanded Outline. September, 2003.

MORGENTHAU, Hans. Politics among nations: the struggle for power and peace. New York: Alfred Knopf, 1973.

MUNICH RE. Topics Geo Annual review: Catastrophes 2004. Disponível em: http://www.munichre.com/publications/302-04321 en.pdf. Acessado em 14/02/2007.

NOVAGERAR. Projeto de Aproveitamento do Biogás de Aterro Sanitário. Documento de Concepção do Projeto. Preparado para a Unidade de Financiamento de Carbono (PCF - Prototype Carbon Fund) do Banco Mundial. Fevereiro de 2004.

PEREIRA, André Santos. Do fundo ao mecanismo: gênese, características e perspectivas para o mecanismo de desenvolvimento limpo; ao encontro ou de encontro à equidade? Rio de Janeiro, 2002.

RIBEIRO,H. e GÜNTHER, W. Urbanização, Modelo de Desenvolvimento e a Problemática dos Resíduos Sólidos Urbanos. In: Patrimônio Ambiental Brasileiro, Edusp, São Paulo, 2003.

RIBEIRO, Wagner.C. Por dentro da Rio-92. In: SALES, W. (org.). Ecos da Rio 92: Geografia, Meio Ambiente e Desenvolvimento em Questão. Fortaleza, AGB, 1992.

, Wagner. C. A ordem ambiental internacional. São Paulo: Contexto, 2001.

, Wagner.C. Mudanças Climáticas, realismo e multilateralismo. Revista Terra Livre. São Paulo, ano 18, vol. I, nº 18 - pág. 75-84, 2002.

, Wagner. C. O Brasil e a Rio+10. In: Revista do Departamento de Geografia, 15 (2002).

, Wagner. C.(org.) Patrimônio Ambiental Brasileiro. São Paulo: Editora da Universidade de São Paulo: Imprensa Oficial do Estado de São Paulo, 2003.

ROCHA, M.T. Aquecimento global e o mercado de carbono: uma aplicação do modelo CERT. Tese apresentada para obtenção do título de doutor. Escola superior de agricultura Luiz de Queiroz. Piracicaba, 2003.

SACHS, Ignacy. Ecodesenvolvimento: Crescer sem destruir. São Paulo: Vértice, 1986. 
Ignacy. Rumo à ecossocioeconomia: teoria e prática do

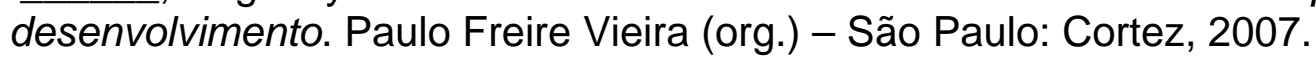

UNITED STATES. The World Bank. State and Trends of the Carbon Market 2007. Washington, D.C. - May 2007. 